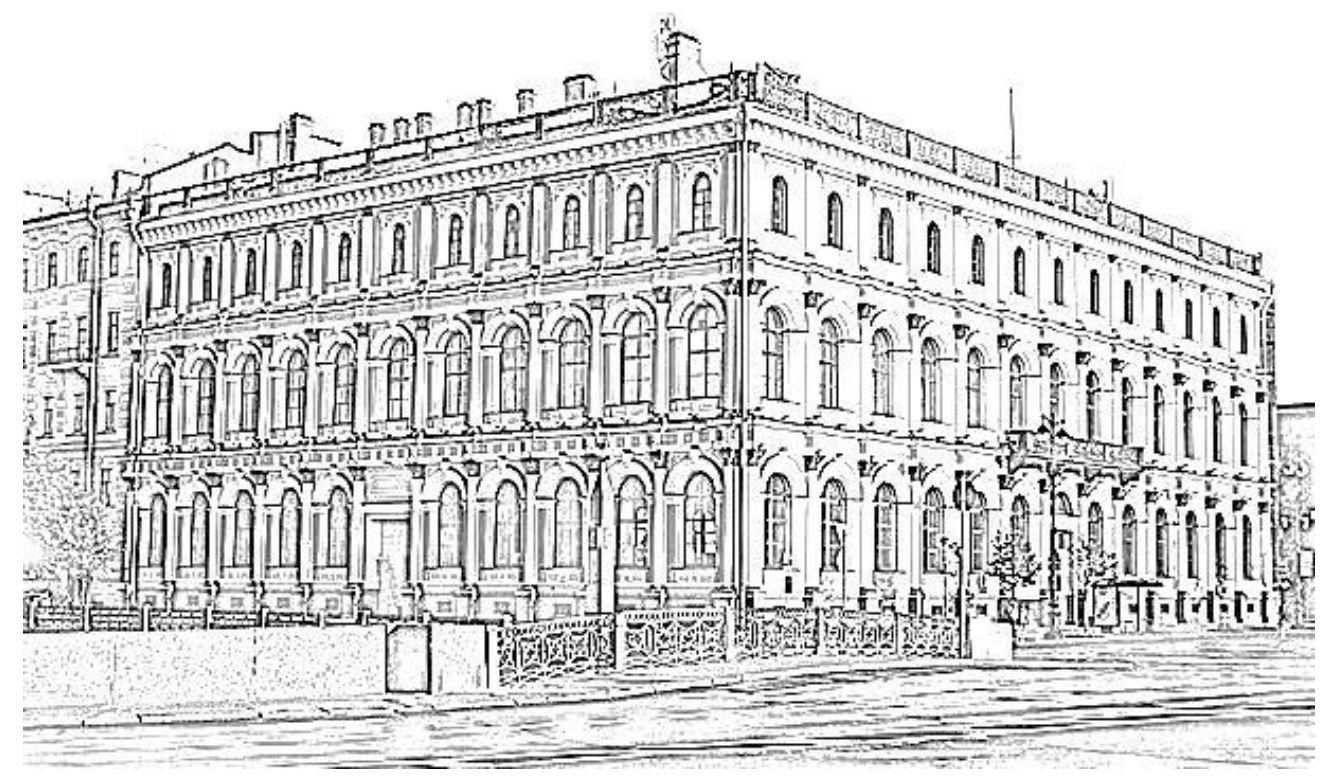




\section{PROCEEDINGS ON APPLIED BOTANY, GENETICS AND BREEDING}

\section{volume 178}

issue 1

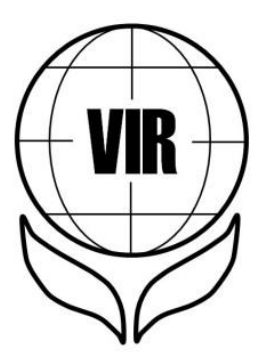

\section{Editorial board}

O. S. Afanasenko, I. N. Anisimova, G. A. Batalova, L. A. Bespalova, N. B. Brutch, Y. V. Chesnokov, A. Diederichsen, M. V. Duka, N. I. Dzyubenko (Chief Editor), N. Friesen, K. Hammer, A. V. Kilchevsky, M. M. Levitin, I. G. Loskutov, S. S. Medvedev, O. P. Mitrofanova, A. I. Morgunov, H. A. Muminjanov, MA. Pintea, E. K. Potokina, E. E. Radchenko, I. D. Rashal, A. V. Rodionov, Z. Sh. Shamsutdinov, M. M. Silantyeva, T. N. Smekalova, I. A. Tikhonovich, J. Turok, E. K. Turuspekov, M. A. Vishnyakova.

Editor in charge of this issue: E. A. Sokoilova, N. I. Dzyubenko 


\section{ТРУДЫ ПО ПРИКЛАДНОЙ БОТАНИКЕ, ГЕНЕТИКЕ И СЕЛЕКЦИИ}

\section{том 178 \\ выпуск 1}

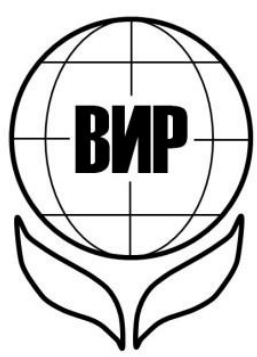

\section{Редакционная коллегия}

И. Н. Анисимова, О. С. Афанасенко, Г. А. Баталова, Л. А. Беспалова, Н. Б. Брач, М. А. Вишнякова, А. Дидериксен, Н. И. Дзюбенко (главный редактор), М. В. Дука, А. В. Кильчевский, М. М. Левитин, И.Г.Лоскутов, С. С. Медведев, О.П. Митрофанова, А.И. Моргунов, Х. А. Муминджанов, Е. К. Потокина, М. А. Пьнтя, Е. Е. Радченко, И. Д. Рашаль, А. В. Родионов, М. М. Силантьева, Т. Н. Смекалова, . А. Тихонович, Й. Турок, Е.К. Туруспеков, Н. В. Фризен, Ю. В. Чесноков, К. Хаммер, 3. Ш. Шамсутдинов.

Ответственные редакторы выпуска $E$. А. Соколова, Н. И. Дзюбенко 
DOI: $10.30901 / 2227-8834-2017-1$

УДК 58:631.52:633/635(066)

ТРУДЫ ПО ПРИКЛАДНОЙ БОТАНИКЕ, ГЕНЕТИКЕ И СЕЛЕКЦИИ. Т. 178. ВЫП. 1. СПб., 2017. $120 \mathrm{c}$.

Освещена 100-летняя история изучения и использования генетических ресурсов засухо- и солеустойчивых кормовых культур, и их диких родичей в республиках Средней Азии и южных регионах России. Дана оценка жизнеспособности образцов ежевики в условиях предгорной зоны Северного Кавказа после их хранения в культуре in vitro. Рассмотрены итоги работы по разработке технологии селекции низкопентозановой озимой ржи и созданию сортов, пригодных для использования в комбикормовой промышленности. Обобщены результаты изучения коллекции нута в Омской области. Приведены достижения селекции по улучшению зимостойкости овса в Польше, выделены эффективные источники зимостойкости для получения новых гексаплоидных линий. Представлена история селекции овса на Кубани. Продемонстрированы возможности использования морфолого-биологических признаков при экспертизе сортов на отличимость, однородность и стабильность на примере сортов гибридной алычи селекции Никитского ботанического сада. Обсуждается генетический контроль восстановления фертильности пыльцы у линий льна с цитоплазматической мужской стерильностью. Рассмотрены результаты применения молекулярных маркеров генов устойчивости к картофельной цистообразующей нематоде на разных этапах селекции картофеля. Представлен биографический очерк выдающегося цитогенетика Г. А. Левитского.

Табл. 33, рис. 14, библиогр. 173 назв.

Для ресурсоведов, ботаников, генетиков, селекционеров, преподавателей вузов биологического и сельскохозяйственного профиля.

PROCEEDINGS ON APPLIED BOTANY, GENETICS AND BREEDING. Vol. 178. Iss. 1. SPb., 2017. $120 \mathrm{p}$.

The 100-year history of studying and utilizing genetic resources of drought- and salt-resistance forage crops and their wild relatives in the republics of Central Asia and southern regions of Russia is highlighted. The viability of blackberry accessions in the environments of the foothill zone of Northern Caucasus is assessed after their in vitro conservation. The results of the work on the development of low-pentosan winter rye breeding are discussed as well as the production of cultivars suitable for feed mill industry. The results of researching the chickpea collection in Omsk Province are summarized. Breeding achievements in improving winter hardiness in oats in Poland are presented, and effective sources of winter hardiness have been identified to obtain new hexaploid lines. The history of oat breeding in Kuban is related. Possibilities of using morpho-biological traits for expert examination of hybrid cherry plum varieties for their distinctness, homogeneity and stability are demonstrated using the cultivars developed at Nikitsky Botanical Garden. Genetic control over pollen fertility restoration in flax lines with cytoplasmic male sterility is discussed. The results of applying molecular markers of potato cyst nematode resistance genes are analyzed at various stages of potato breeding. A biographic essay about the outstanding cytogeneticist G. A. Levitsky is presented.

Tabl. 33, Fig. 14, Ref. 173.

Addressed to genetic resources experts, geneticists, plant breeders and lecturers of biological and agricultural universities and colleges.

ISSN 2227-8834

Федеральный исследовательский центр

Всероссийский институт

генетических ресурсов растений имени Н. И. Вавилова,

ПИ № ФС77-57455 


\section{ИЗУЧЕНИЕ И ИСПОАЬЗОВАНИЕ ГЕНЕТИЧЕСКИХ РЕСУРСОВ РАСТЕНИЙ}

DOI: $10.30901 / 2227-8834-2017-1-5-23$

УДК 633.2: 631.524.85:

632.122.1: $581.1 .051(069.5)$

Н. И. Дзюбенко,

А. В. Бухтеева,

А. А. Кочегина

Федеральный

исследовательский центр

Всероссийский институт

генетических ресурсов

растений имени

Н. И. Вавилова,

190000 Санкт-Петербург,

ул. Б. Морская д. 42, 44,

Россия,

e-mail: akochegina@rambler.ru

Ключевые слова:

коллекция кормовых трав

ВИР, засухоустойчивость, солетолерантность, лючерна, молекулярные маркеры

Поступление:

08.12.2016

Принято:

06.03.2017

\section{МНОГОЛЕТНИЕ И ОДНОЛЕТНИЕ ЗАСУХО- И СОЛЕУСТОЙЧИВЫЕ КОРМОВЫЕ РАСТЕНИЯ В ВАВИЛОВСКОЙ КОЛЛЕКЦИИ}

За последние 100 лет ВИР провел многочисленные экспедиции в Казахстан, республики Средней Азии, южные регионы России, а также в ряд зарубежных стран. Был собран ценный исходный материал засухо- и солеустойчивых кормовых культур, и их диких родичей - житняка, ломкоколосника, засухоустойчивых видов люцерны, донника и эспарцета, аридных кормовых. В результате 20 -летнего изучения кормовых растений на Приаральской опытной станции ВИР выделены три группы растений с высокой, средней и слабой засухоустойчивостью, определено 20 источников засухоустойчивости. В живом виде на Приаральской опытной станции ВИР (ныне в ведении Республики Казахстан) поддерживались коллекции саксаула, кохии простертой, жузгуна, терескена, камфоросмы, полыни, астрагала, кейреука и других пустынных растений.

На основе коллекции сотрудники ВИР, а также других селекционных учреждений создали ценные сорта житняка сибирского, ломкоколосника ситникового, люцерны изменчивой, эспарцета песчаного, пырейника шероховатостебельного, кохии простертой.

Теоретические и практические исследования по физиологии пустынных растений, начатые выдающимся ученым ВИР Н. А. Максимовым (Государственная премия СССР 1929 г. за цикл работ о морозо- и засухоустойчивости), были продолжены в послевоенные годы. Создан цикл методических разработок по оценке засухо- и солеустойчивости образцов коллекции. Использование молекулярных маркеров для оценки солеустойчивости люцерны посевной позволило выявить ген $S r l k$, контролирующий устойчивость к засолению у люцерны посевной.

Ценность Вавиловской коллекции, в том числе засухо- и солеустойчивых кормовых растений, в связи с текущей потерей биоразнообразия возрастает. 


\section{STUDYING AND UTILIZATION \\ OF PLANT GENETIC RESOURCES}

N. I. Dzyubenko,

A. V. Bukhteeva, A.

A. Kochegina

The N. I. Vavilov

All-Russian Institute

of Plant Genetic Resources,

42, 44, Bolshaya Morskaya str.,

St. Petersburg,

190000 Russia,

e-mail: akochegina@rambler.ru

Key words:

VIR collection of forage plants, drought-resistant forage plants, drought and salt resistance, alfalfa, molecular markers

\section{Received:}

08.12.2016

Accepted:

06.03.2017

\section{PERENNIAL AND ANNUAL DROUGHT- AND SALT- RESISTANT FORAGE PLANTS IN THE VAVILOV COLLECTION}

In the past 100 years' scientists of VIR conducted numerous expeditions to Kazakhstan, the republics of Central Asia, the southern regions of Russia, and to a number of foreign countries. As a result, valuable germplasm was collected, examined and added to the Vavilov collection of global genetic resources of drought- and salt-resistant forage crops and their wild relatives - wheatgrass, Russian rye, drought-resistant species of alfalfa, sweet clover, and others. The 20-year field studies of forage plants at the Aral Experiment Station provided grounds for the division of all plants into 3 groups: with high, medium and low resistance to drought. Twenty sources of drought resistance were identified. The collections of Haloxylon, Kochia prostrata, Eurotia, Calligonum, Camphorosma, Artemisia, Astragalus, Salsola orientalis and other desert plants were maintained at the Aral Experiment Station in vivo.

Breeders from VIR and other breeding centers developed numerous varieties of alfalfa, Siberian wheatgrass, Russian rye, sandy sainfoin, slender wheatgrass, forage kochia.

Theoretical and practical research on the physiology of desert plants started by the outstanding Russian scientist N. A. Maximov (the State Prize of the USSR in 1929 for a series of works on frost and drought resistance) continued in the postwar years. A set of methodological recommendations to evaluate drought and salt resistance of the collection was worked out. Molecular methods for the assessment of salt tolerance levels in alfalfa were applied, and the Srlk gene controlling resistance to salinity was identified. 


\section{Введение}

В связи с глобальным потеплением климата на нашей планете и усиливающимися процессами аридизации значительной части территории нашей страны интерес к многолетним засухоустойчивым и солеустойчивым кормовым культурам, в особенности растущим на богаре (без полива), возрастает. Особо актуальной для нашей страны эта тематика становится в условиях непрекращающихся экономических санкций, когда забота о продовольственной безопасности государства выходит на передний план.

По степени засушливости на территории Российской Федерации выделены 3 биоклиматические зоны, охватывающие более 160 млн. га: пустынная, полупустынная и сухостепная (Shamsutdinov et al., 2013). Bce эти зоны относятся к территориям с аридными условиями. К пустынной биоклиматической зоне общей площадью около 9 млн. га относятся Прикаспий, Черные земли Республики Калмыкия, Кизлярские пастбища Дагестана и прилегающая часть Астраханской области. В полупустынную зону площадью около 45 млн. га входят: часть территории Дагестана, Северной Осетии, Ставропольского края, Калмыкии, Тывы, Бурятии, а также Волгоградской, Оренбургской, Омской, Читинской областей. Сухостепная зона общей площадью более 106 млн. га занимает часть территории Калмыкии, Дагестана, Северной Осетии, Ставропольского края, юг Воронежской, Волгоградской, Ростовской, Оренбургской, Омской, Челябинской и Читинской областей. Коэффициент аридности этих биоклиматических зон соответственно 0,20 0,$45 ; 0,45-0,60 ; 0,60-0,80$. Вероятность сухих и засушливых лет, соответственно, более $30 \%$, более $20-30 \%$ и $20-30 \%$. За более чем 100-летний период мобилизации генетических ресурсов многолетних засухоустойчивых кормовых культур и их диких родичей на территории бывшего СССР, а также ряда зарубежных стран ученые ВИР провели изучение ценных морфобиологических признаков ксеро- и галотолерантности многих пустынных кормовых растений в лабораторных и полевых условиях. На опытных станциях ВИР - Приаральской, Астраханской, Кубанской, Среднеазиатском филиале - было выделено 20 источников засухоустойчивости. Шесть сортов ученые ВИР рекомендовали в качестве источников засухоустойчивости многолетних кормовых культур. Среди них житняк сибирский сорт 'Актюбинский узкоколосый', ломкоколосник ситниковый сорт 'Шортандинский', саксаул черный сорт 'Приаральский 1', которые сочетают признаки засухоустойчивости с зимостойкостью. Сорт 'Актюбинский узкоколосый' образца из Актюбинской области помимо того обладает признаком жаростойкости. Сорт 'Карнабчульский' кохии простертой из образца ферганского каменистого экотипа обладает высокой продуктивностью и засухоустойчивостью. Люцерна изменчивая сорта 'Тибетская' обладает высокой засухоустойчивостью и семенной продуктивностью. Для сельскохозяйственного производства сухостепной и аридной зон были рекомендованы перспективные кормовые культуры и стародавние засухоустойчивые сорта (Burenin et al., 1988).

При использовании образцов коллекции ВИР были выведены такие популярные засухоустойчивые сорта кормовых культур как люцерна изменчивая 'Аридная', 'Армянская', 'Смуглянка', Вавиловка'; эспарцет песчаный - 'Алмаатинский 2' и 'Оренбургский’; ломкоколосник ситниковый 'Шортандинский'; пырейник шероховатостебельный 'Карабалыкский 86'.

\section{Коллекция засухо- и солеустойчивых кормовых растений - часть Вавиловской коллекции. История создания}

Изучение засухоустойчивых кормовых растений было начато известным ботаником, заведующим Бюро по прикладной ботанике Робертом Эдуардовичем Регелем в тяжелые военные годы 1914-1915 (Regel, 1915). Бюро было учреждено при Ученой комиссии Главного управления землеустройства и земледелия России в 1894 г., однако его деятельность на первых порах из-за недостаточного финансирования и крайне малого штата сотрудников была только информационной. Регель был назначен директором Бюро в 1905 г., и работа учреждения сильно оживилась. Первый образец кормовых культур - клевер луговой (красный) Trifolium pratense var. foliosum Brend - был зарегистрирован в коллекции луговых трав в 1907 г. (Dzyubenko N., Dzyubenko E., 2012), а к концу 1914 г. коллекция луговых трав насчитывала 490 образцов. Одним их первых образцов засухоустойчивых кормовых растений был персидский клевер-шабдар. Он был привезен известным ботаником В. 
А. Кузнецовым, обследовавшем в середине 20-х годов прошлого века солончаковостепную кормовую растительность воронежской Каменной степи, при- и зауральские территории, а также Сыр-Дарьинскую территорию Туркестана. В. А. Кузнецов работал в Бюро по прикладной ботанике с апреля 1911 г. и описал ряд видов и форм кормовых растений (Pavluhin, Kirillov, 1994). В 1920-30 гг. Владимир Александрович являлся систематиком, географом и экологом, заведующим отделом Института прикладной ботаники и новых культур. В 1926 г. по результатам экспедиционного изучения географического распространения важнейших кормовых видов клевера и люцерны он опубликовал сводку (Kuznetsov, 1926), в которой впервые были составлены ареалы видов люцерны и клевера и доказана первичность происхождения этих культур в Евразии. В. А. Кузнецов явился родоначальником направления исследований новых кормовых культур. Ежегодно он публиковал статьи по новым и вновь вводимым в культуру кормовым растениям: житняк, донник, тефф, дагусса, персидский клевер-шабдар и другим. Работы по изучению засухоустойчивых многолетних кормовых культур и их диких родичей были продолжены в Воронежском степном и Туркестанском полупустынном отделениях. После революции и Гражданской войны требовалось пополнение коллекции. Образцы клевера, донника, люцерны были собраны в разных зонах СССР, для этих целей с 1922 по 1933 г. были предприняты 184 экспедиции. В коллекцию привлекались также зарубежные образцы кормовых растений США, Европы и местных сортов Передней и Центральной Азии.

Первичное изучение образцов коллекции многолетних и однолетних засухоустойчивых кормовых растений в довоенные годы провели сотрудники ВИР на Приаральской опытной станции (Dzyubenko, Kochegina, 2016, pp. 19, 20, 22).

В послевоенные годы из-за утраты части образцов началась интенсивная мобилизация многолетних кормовых растений пустынной флоры и пополнение коллекций. В 1970-1993 гг. ВИР организовал 138 экспедиций, в результате было привлечено 11038 образцов кормовых растений с территории Европейской части страны, из Сибири и Центральной Азии. Результаты многолетних экспедиций в Казахстан были обобщены в книге «Ресурсы многолетних кормовых растений Казахстана» (Ivanov, Soskov, Bukhteeva, 1986, by Dzyubenko, Kochegina, 2016, p. 26). К 2015 году коллекция кормовых культур составила более 32 тысяч образцов, в том числе засухоустойчивых растений - более 3 тысяч (Dzyubenko, 2015).

\section{Классификация засухоустойчивых кор- мовых растений по Н. И. Вавилову}

На Всесоюзной конференции по борьбе с засухой в 1931 г. Н. И. Вавилов разделил все многообразие видов и родов растений на три группы: наиболее засухоустойчивые, промежуточные и наименее засухоустойчивые (Vavilov, 1931). В первую группу он отнес такие кормовые культуры, как житняк, серповидную люцерну, донник, овсяницу овечью (типчак), в промежуточную (вторую) группу вошли - костер безостый, эспарцет, люцерна, пырей собачий, пырей американский. В соответствии с планом мобилизации генетических ресурсов засухоустойчивых кормовых культур и их диких родичей, намеченным Н.И.Вавиловым, сотрудники отдела кормовых культур ВИР обследовали территорию бывшего СССР и ряда зарубежных стран и в ходе многочисленных экспедиций собрали ценный материал и создали коллекцию засухоустойчивых кормовых растений. На Приаральской опытной станции ВИР в зоне пустыни за период около четверти века ученые провели агробиологическое изучение более 5 тысяч образцов кормовых культур (в том числе более 700 аридных) на орошении и богаре в условиях полевого опыта. Засухоустойчивость оценивали в баллах, причем были выделены, с учетом высокой продуктивности, следующие три группы (Burenin et al., 1988):

- в первую группу - засухоустойчивость высокая (7-9 баллов) вошли:

Haloxylon ammodendron (C.A. Mey) Bunge - Саксаул черный (северотуранский и южнотуранский экотипы), используется для создания пастбищезащитных полос;

Krascheninnikovia ewersmanniana (Borszcz.) Grub. - Терескен Эверсманна - пастбищное растение;

Calligonum aphyllum (Pall.) Guerke Жузгун безлистный - пастбищное растение;

Calligonum caput-medusae Schrenk. Жузгун голова медузы - пастбищное растение; 
Salsola orientalis S.G. Gmel. - Солянка восточная (кейреук) - малораспространенное пастбищное растение;

Camphorosma monspeliaca L. - Камфоросма марсельская (монпелийская) - малораспространенное пастбищное растение;

Halothamnus subaphyllus (C.A. Mey) Botsch. - Галотамнус малолистный (чогон) - малораспространенное пастбищное растение;

Salsola Paletzkiana Litv., Salsola Richteri Kar. ex Litv. - Черкезы Палецкого и Рихтера - пастбищное растение;

Astragalus varius S.G. Gmel. - Астрагал изменчивый - пастбищное растение;

Agropyron fragile subsp. sibiricum (Willd.) Melderis - Житняк сибирский - пастбищное растение;

Agropyron desertorum (Fish. ex Link) Schult. - Житняк пустынный - сенокосное, реже пастбищное растение;

Agropyron fragile (Roth) Candargy Житняк ломкий;

Agropyron cristatum (L.) Beauv. - Житняк гребенчатый - сенокосное, реже пастбищное растение;

Festuca valesiaca Gaudin - Овсяница валисская (типчак) - пастбищное растение;

Corispermum orientale Lam. - Верблюдка восточная - однолетнее пастбищное и зерновое растение;

Salsola foliosa (L.) Schrad. - Солянка облиственная - однолетнее зерновое растение;

- вторая группа - средняя засухоустойчивость (5 - 7 баллов), включает:

Medicago coerulea Less ex Ledeh. - Люцерна голубая;

Medicago falcata L. - Люцерна серповидная;

Medicago trautvetteri Sumn. - Люцерна Траутветтера;

Onobrychis tanaitica Spreng. - Эспарцет песчаный;

Melilotus polonicus (1.) Pall. - Донник каспийский;

Psathyroctachys juncea (Fisch.) Nevski Ломкоколосник ситниковый;

Elytrigia intermedia (Host.) Nevski - Пырей средний;

Lophopyrum elongatum (Host) A.Love Пырей продолговатый;

Roegneria trachycaulon Nevski - Регнерия шероховатостебельная (пырей бескорневищный);

Elymus sibiricus L. - Волоснец сибирский;
Amaranthus cruentus L. Амарант багряный, однолетнее растение;

Amaranthus caudatus L. - Амарант хвостатый, однолетнее растение;

Kochia scoparia (L.) Schrad. - Кохия веничная, однолетнее растение;

Trigonella foenum-graecum L. - Пажитник сенной, однолетнее растение.

Три самые засухоустойчивые культуры (Haloxylon ammodendron, Krascheninnikovia ewersmanniana, Calligonum aphyllum) c большим успехом используются при создании пастбищезащитных полос и для укрепления песков.

\section{Коллекция житняка и ломкоколосника ситникового}

Базовой площадкой для поддержания и изучения коллекций аридных злаков служила Приаральская опытная станция ВИР, расположенная в Актюбинской области Западного Казахстана. В послевоенные 50-е годы прошлого столетия некоторые станции передали туда образцы своих сборов житняка. Так, Краснокутская селекционная станция передала коллекцию профессора В. С. Богдана. Образцы, собранные еще в начале прошлого столетия, во избежание переопыления были перенесены клонами и высажены на изолированные участки. Они числятся в коллекции как сортотип В. С. Богдана, так как уже многие десятки лет находятся в культуре.

Сбор коллекции житняка и ее первичное изучение в середине 60-х проводили сотрудники станции Ю. И. Кириллов и И. Е. Козуля, а с конца 60-х оценкой коллекции житняка по хозяйственно ценным признакам в течение длительного времени занималась А. В. Бухтеева.

Биологическое изучение образцов житняка на Приаральской опытной станции ВИР на 90 образцах коллекции в условиях пустыни Западного Казахстана в 1969-1971 гг. выполнил В. И. Козырев (Kozyrev, 1972, by Bukhteeva et al., 2016, p. 253). Среди исследованных образцов присутствовали и сортотипы В. С. Богдана.

Виды житняка изучали и в естественных ценозах. Во время экспедиционных маршрутов по Западному Казахстану проводили сбор высокопродуктивных, устойчивых к аридным условиям форм житняка узкоколосого и ширококолосого, затем - морфобиологическое изучение образцов коллекции по продуктивности, соле- и засухоустойчивости и другим хозяйственно цен- 
ным признакам с целью дальнейшего использования в качестве исходного материала для селекции. Полевое изучение коллекции житняка в 80-90-е гг. осуществляли сотрудники станции Л. Л. Малышев и М. К. Такаева. По результатам оценки житняка пустынного и житняка сибирского (Agropyron desertorum и A. fragile) в условиях Северного Приаралья М. К. Такаева и Л. Л. Малышев успешно защитили кандидатские диссертации (Maly`shev, 1997;
Takaeva, 2000, by Bukhteeva et al., 2016, pp. $256,260)$.

В 1981 и 1989 гг. были опубликованы два Каталога коллекции мировых генетических ресурсов ВИР «Житняк» (Bukhteeva, 1981; Bukhteeva et al., 1989, by Bukhteeva et al., 2016, p. 251). В последнем издании была представлена подробная биоморфологическая характеристика 92 образцов коллекции житняка, а также разработана их подробная эколого-географическая классификация

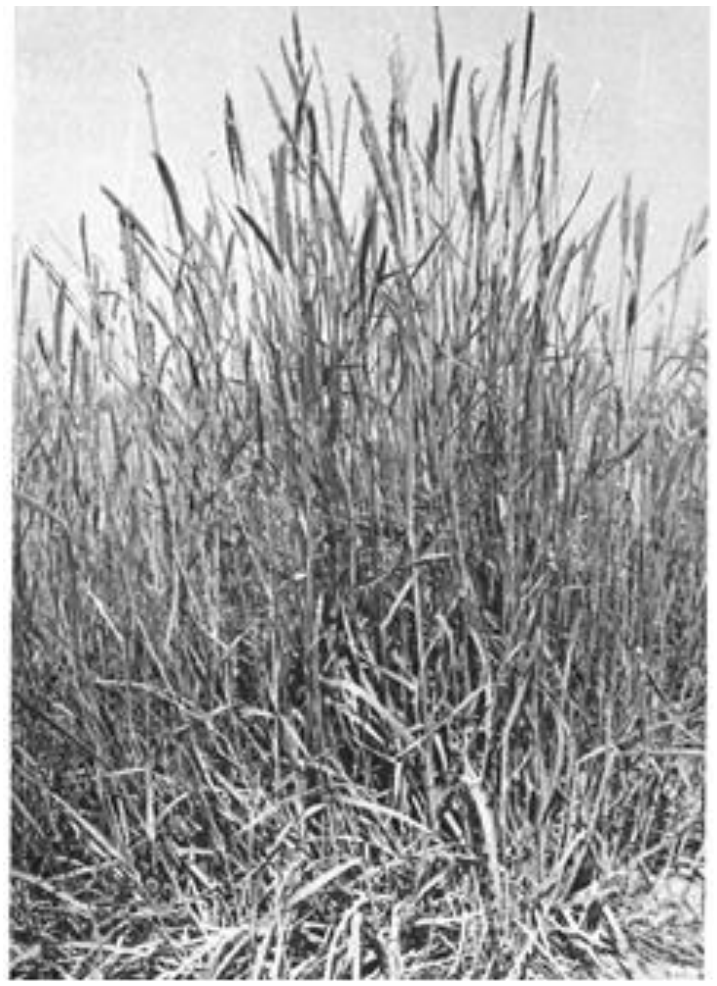

Рис. 1. Житняк ломкий на восточном побережье Каспийского моря, 1969. Фото А. В. Бухтеевой.

Fig. 1. Siberian wheatgrass on the eastern coast of the Caspian Sea, 1969. Photo by A. V. Buhteeva.

Многие виды кормовых злаков имеют кариологические расы. Была проведена оценка уровней плоидности 219 образцов житняка из коллекции ВИР сотрудниками Казахстанского НИИ лугопастбищного хозяйства Е. М. Шахановым и Р. Г. Ушаковой. В отделе кормовых культур ВИР (А. В. Бухтеева) изучали экологическую приуроченность выделенных кариологических рас (Bukhteeva, 1988). При нанесении на карту образцов обнаружилось, что каждая кариологическая раса заняла свой обособленный ареал, что подтвердило идею о дивергенции диплоидных и тетраплоидных рас житняка. Оказалось, что диплоидная разновидность приурочена к районам с экстремаль- ным проявлением климатических факторов (Прикаспий, Причерноморье и Западный Казахстан), тетраплоидная - к остальным районам степной зоны. Различия растений разных кариологических рас были оценены как экотипические, значимые таксономические различия отсутствовали. Идея о приуроченности диплоидных рас к более экстремальным условиям среды по сравнению с тетраплоидными расами требует дальнейшего изучения на других видах злаковых и бобовых растений.

Результаты многолетних исследований коллекции житняка коллектив отдела генетических ресурсов многолетних кормовых культур ВИР обобщил в монографии «Ге- 
нетические ресурсы житняка Agropyron Gaertn.» (Bukhteeva et al., 2016).

Среди лучших сортов станции, созданных еe сотрудниками для выращивания на богарных участках, следует отметить житняк сибирский 'Актюбинский узкоколосый' и 'Актюбинский ширококолосый'. Эти сорта остаются актуальными и в наше время. Житняк сибирский, несмотря на свои высоко засухоустойчивые свойства, является также весьма экологически пластичным растением. Он активно продвигается в западном направлении (в природе и культуре), увеличивая при этом свою мощность и продуктивность. Селекционеры уже оценили это свойство и создали новые сорта для районов, где житняк прежде не произрастал. Так, в Орловской области селекционеры Орловского ГАУ создали новый сорт житняка сибирского 'Викровт'. Коллекции житняка и ломкоколосника ситникового пополнялись в течение ряда лет и в настоящее время насчитывают: коллекция житняка - более 800 образцов, ломкоколосника ситникового - около 200.

\section{Коллекция бобовых: люцерна, донник, эс- парцет, астрагал}

В отделе кормовых культур Приаральской опытной станции ВИР многолетнее изучение образцов коллекции многолетних трав люцерны и донника проводилось с начала 1960-х гг. под руководством А. И. Иванова. Им были выделены жаростойкие и солевыносливые сорта и образцы, отзывчивые на орошение. Кроме того, для условий богары были рекомендованы засухоустойчивые и зимостойкие образцы. Результаты многолетних исследований люцерны на Приаральской опытной станции были обобщены в монографии А. И. Иванова «Люцерна», (Ivanov, 1980) и книге «Ресурсы многолетних кормовых растений Казахстана» (Ivanov, Soskov, Bukhteeva, 1986, by Dzyubenko, Kochegina, 2016, p. 26).

В ВИРе уделялось большое внимание проблеме повышения семенной продуктивности люцерны. Совместно с отделом Цитологии и анатомии ВИР был разработан цикл методических указаний: «Проведение самоопыления, гибридизации, учета самофертильности и автотриппинга у люцерны» (Ivanov, Dzyubenko, Bukhteeva, 1982). «Oтбор растений люцерны с высокой плодовитостью завязей» (Orel et al., 1985), «Экспресс-методы определения фертильности зародышевых мешков люцерны» (Orel et al.,
1988), «Способ выделения и характеристика типов растений с полной женской стерильностью у люцерны» (Orel et al., 1991. В отделе проводилось многостороннее изучение культивируемой люцерны, данной культуре посвящены многие диссертационные работы, защищенные в отделе ГР многолетних кормовых культур (Lubenets, 1953; Ivanov, 1977; Dzyubenko, 1983, 1995; Duk, 1989; Maly'sheva, 1997).

В настоящее время коллекция многолетних видов люцерны насчитывает более 4700 образцов, однолетних - более 800 образцов. Адаптированными к аридным условиям являются следующие виды: Medicago varia T. Martyn, Medicago sativa L., Medicago difalcata Sinsk., Medicago trautvetteri, Medicago caerulea, Medicago falcata, Medicago tianshanica Vass. Все они предназначены для пастбищного использования и представлены в коллекции. Среди лучших сортов, созданных сотрудниками Приаральской опытной станции, - люцерна 'Тибетская', 'Приаральская'. Коллекция донника насчитывает свыше 1200 образцов. Важное значение имеет вид, адаптированный к аридным условиям - Melilotus dentatus (Waldst. et Kit.) Pers. Актуальной является тема «Скрининг видового разнообразия донника на устойчивость к хлоридному засолению» (Dzyubenko et al., 2017, in print). Коллекции эспарцета включает свыше 100 образцов. Коллекция астрагала насчитывает 48 видов и около 200 образцов. Семь видов относятся к засухоустойчивым. Среди них астрагал шершавый (Astragalus asper Jacq), астрагал песчанодревесный (A. ammodendron Bunge), астрагал короткозубый (A. brevidens Freyn et Sint.), астрагал коротконогий (A. brachypus Schrenk), астрагал эспарцетовый (A. onobrychis L.), астрагал понтийский $A$. ponticum Pall., астрагал бороздчатый (A. sulcatus L.).

\section{Коллекция аридных растений: кохии про- стертой, терескена, камфоросмы, кейре- ука, полыни, жсузгуна, саксаула и других}

Изучение кохии простертой (прутняка, изеня) в крайне жестких аридных условиях Приаральской опытной станции ВИР в естественных злаково-полынных пастбищах и сенокосах песчаного массива Большие Барсуки было начато в 1935-1936 гг. M. С. Коликовым (Kolikov, 1939, by Dzyubenko, Kochegina, 2016, p. 28).

С 1969 г. ВИР приступил к созданию коллекции кохии простертой и других рас- 
тений пустынной флоры в условиях Приа- песчаный экотип, по кустистости - ферганральской опытной станции, на светло- ский каменистый, по облиственности - секаштановых супесчаных почвах. В создании веротуранский солонцовый $\quad(58,0 \%)$, по и оценке образцов коллекции принимали урожайности воздушно-сухой кормовой участие сотрудники ВИР заведующий отде- массы и семян - калмыцкий песчаный, по лом кормовых культур ВИР П. А. Лубенец, массе 1000 семян - южноказахстанский директор Приаральской опытной станции Н. песчаный. По данным двухлетнего изучеИ. Дзюбенко, профессор Ю. Д. Сосков. ния по содержанию питательных веществ Коллекция сохранялась в живом виде. По (белок, клетчатка, БЭВ) экотипы мало разрезультатам этих исследований были опуб- личались. Отмечено высокое содержание ликованы два каталога ВИР (Soskov, 1974; аминокислот - лизина, лейцина, изолейциSoskov, Semushina, 1981, by Dzyubenko, на, фенилаланина, валина, гистидина и арSoskov, 2014, pp. 279, 280), а также моно- гинина - одинаковое с клевером луговым графия Н. И. Дзюбенко, Ю. Д. Соскова «Ге- или близкое к нему. Аланина, который свянетические ресурсы кохии простертой Ко- зан с засухоустойчивостью, на $50 \%$ больше, chia prostrata L. Shrad.» (Dzyubenko, Soskov, чем в клевере луговом. Наибольшее содер2014).

В 1969-1973 гг. Казахстанской экспедицией ВИР было собрано 147 образцов кохии простертой для изучения в условиях коллекционного питомника, а в последующие 20 лет коллекция пополнилась еще более чем 250 образцами и стала насчитывать свыше 400 образцов (рис. 2).

Агробиологическое изучение проводилось на питомниках в течение 5-7 лет по методике отдела кормовых культур ВИР (Lubenets et al., 1973; Ivanov et al., 1985). T. А. Турганова (Turganova, 1973, 1974, by Dzyubenko, Soskov, 2014, p. 281), защитившая диссертацию под руководством профессора П. А. Лубенца по теме «Изучение дикорастущих образцов кохии простертой в условиях Северного Приаралья», использовала 30 образцов, в том числе образцы из Западного Казахстана, Южного Прибалхашья, Южных Кызыл-Кумов и Ферганской долины, а также из Прикаспийской низменности и Средней Волги. Наиболее продуктивными и устойчивыми оказались местные дикорастущие образцы прутняка из Уральской и Актюбинской областей. В среднем за два года урожай зеленой массы составил 136-218\% к стандарту. Кроме того, были выделены раннеспелые, засухоустойчивые, устойчивые к грибным болезням образцы с высоким содержанием сырого белка и другими хозяйственно ценными признаками.

В 1981-1984 гг. сравнительное изучение по 12 признакам 41 образца кохии простертой, относящихся к 8 экотипам, проводил Ю. Д. Сосков. В условиях богары Северного Приаралья превзошли стандарт (к-105, местный образец аральского супесчаного экотипа): по высоте растений - калмыцкий жание жира отмечено у калмыцкого песчаного экотипа (7,6\% на а.с.в.).

Казахские ученые (Habdolda et al., by Dzyubenko, Soskov, 2014, p. 281) в северотуранском каменистом экотипе обнаружили сверхконцентрацию ( $0,4 \%$ на а.с.в.) гормоноподобного вещества экдистерона, наличием которого объясняются нажировочные свойства корма из кохии. Кроме того, экдистерон проявляет свойства надгормонального регулятора, и может использоваться как программируемый включатель и выключатель генов, а также в качестве плазмидного вектора системы клонирования наследственной информации. Все это открывает новые перспективы для применения этого уникального растения не только в сельском хозяйстве, но и в молекулярной биологии, генной инженерии и медицине.

Терескен обыкновенный и терескен Эверсманна - Krascheninnikovia ceratoides (L.) Gueldenst. и Krascheninnikovia ewersmanniana - очень ценные кормовые полукустарники, так же, как и кохия простертая, относящиеся к сем. Chenopodiaceae Vent. (рис. 3). Терескен принадлежит к группе ксерогалофитов. Он устойчив к засухе и к сульфатному засолению, менее устойчив к сульфатно-хлоридному, а к хлоридному имеет жесткие ограничения: при концентрации $\mathrm{NaCl}$ выше $0,2 \%$ его действие крайне губительно. Как и прутняк, терескен по фотосинтезу относятся к группе $\mathrm{C}_{4}$ растений, очень экономно расходующих влагу и имеющих высокую продуктивность фотосинтеза. Растения быстро отрастают весной и накапливают большой запас ценного высокобелкового корма для скота. 


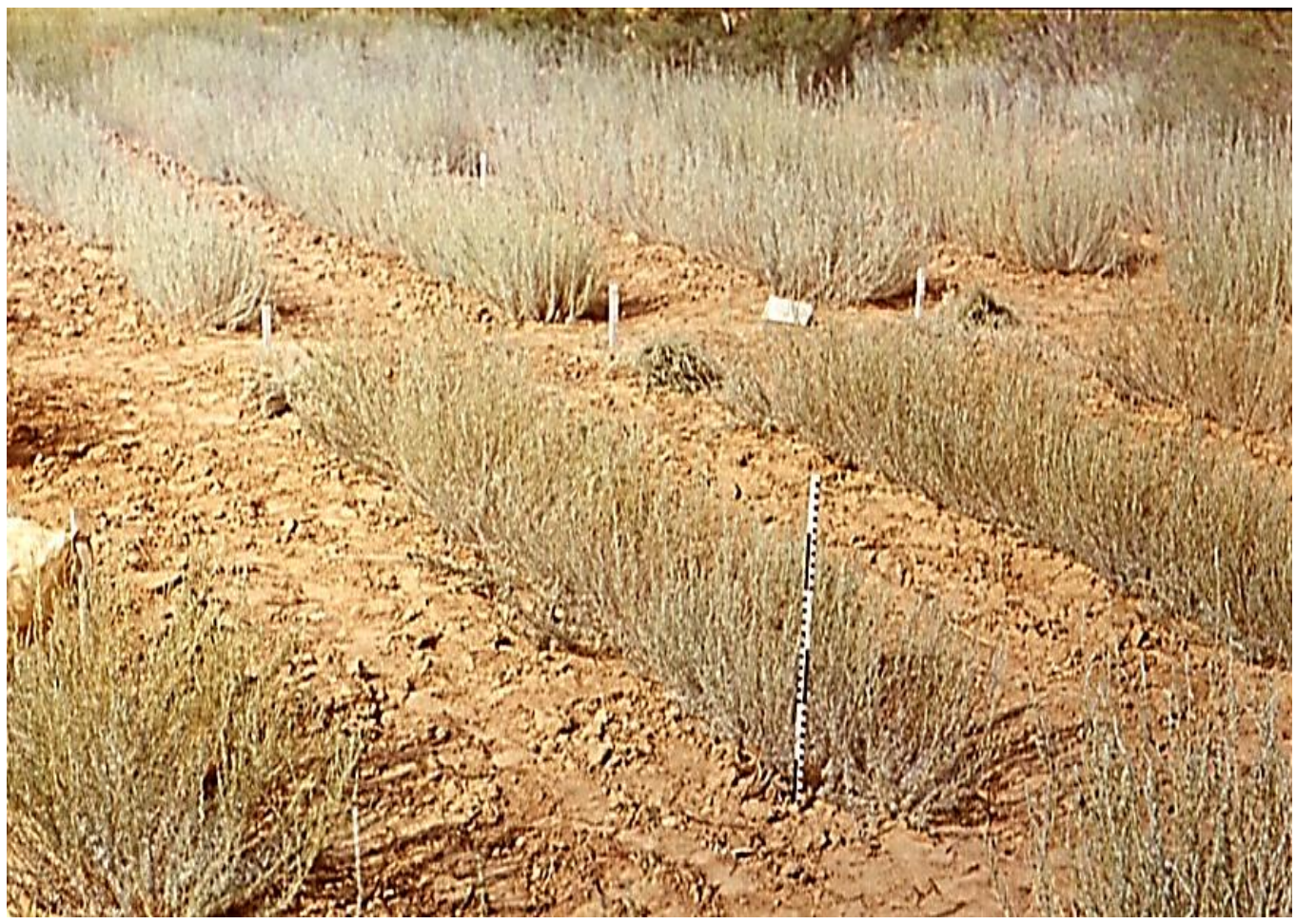

Рис. 2. Северотуранский солонцовый экотип кохии простертой. Казахстан, Актюбинская область, г. Челкар, Приаральская опытная станция ВИР. Фото Ю. Д.Соскова, 1989.

Fig. 2. North Turanic solonetz ecotype of Kochia prostrata (to the right) growing at VIR's Aral Experiment Station in Chelkar, Aktyubinsk Province, Kazakhstan. Photo by Yu. D. Soskov, 1989.

По сравнению с прутняком терескеновый корм относится к более грубым кормам. Наличие кранц-ткани в обкладках сосудистых пучков кохии простертой позволило отнести его в группу слабо специализированных эуксерофитов, а терескен - к неспециализированным эуксерофитам. Терескен служит превосходным фитомелиорантом, часто используется для закрепления эродированных и подверженных процессам опустынивания почв. Поздней осенью 1972 г. на Приаральской опытной станции ВИР был заложен питомник сравнительного комплексного изучения терескена обыкновенного на богаре. Наблюдения проводили по 12-ти признакам в $1972-$ 1979 гг.: 6-ти агробиологическим (5-летний период) и 6-ти химическим (3 года). В конце опыта полные наблюдения были получены по 49 образцам терескена обыкновенного, относящимся к трем экотипам. Терескен Эверсманна (36 образцов) наблюдали в 1987-1989 гг. Образцы обоих видов терескена отличались повышенной устойчивостью к болезням и вредителям, имели $100 \%$ зимостойкость и высокие показатели продуктивности. По результатам исследований коллекции жузгуна профессором Ю. Д. Сосковым была опубликована систематическая монография по афро-азиатскому роду жузгун - Calligonum (сем. Polygonaceae Lindl. - гречишные). (Soskov, 2011, by Dzyubenko, Kochegina, 2016, p. 29) Автор провел глубокий анализ происхождения и центров формирования видового и внутривидового разнообразия. Виды этого рода имеют важнейшее значение для аридных областей Средней и Центральной Азии как фитомелиоративные и кормовые растения. Уже в наше время появляются новые засухо- и солеустойчивые сорта на основе жузгуна безлистного - C. aphyllum. Было проведено комплексное пятилетнее агробиологическое изучение образцов коллекции жузгуна в условиях Приаральской опытной станции ВИР, представляющих основные виды и межвидовые гибриды, населяющие пустыни Средней Азии, Казахстана и РФ. Для селекции в северной подзоне пустынь были выделены перспективные образцы жузгуна с рядом хозяйственно ценных признаков: с высокой зимостойкостью (100\%) - C. acantho-pterum Borszcz. из КзылОрдинской (к-190, к-191), C. × densum Bor- 
szcz. из Джамбулской (к-79, к-80, к-81, к82), C. rubicundum Bunge из ВосточноКазахстанской (к-173), C. $\times$ spinulosum Drob. из Джамбулской (к-77) и КзылОрдинской (к-193) областей.

\section{Изучение механизмов засухо- и соле- $и$ морозоустойчивости. Оценка образцов}

\section{коллекции засухоустойчивых кормовых растений лабораторными методами (история и современность)}

Для аридных кормовых растений наиболее ценными агробиологическими свойствами являются засухоустойчивость и галотолерантность.

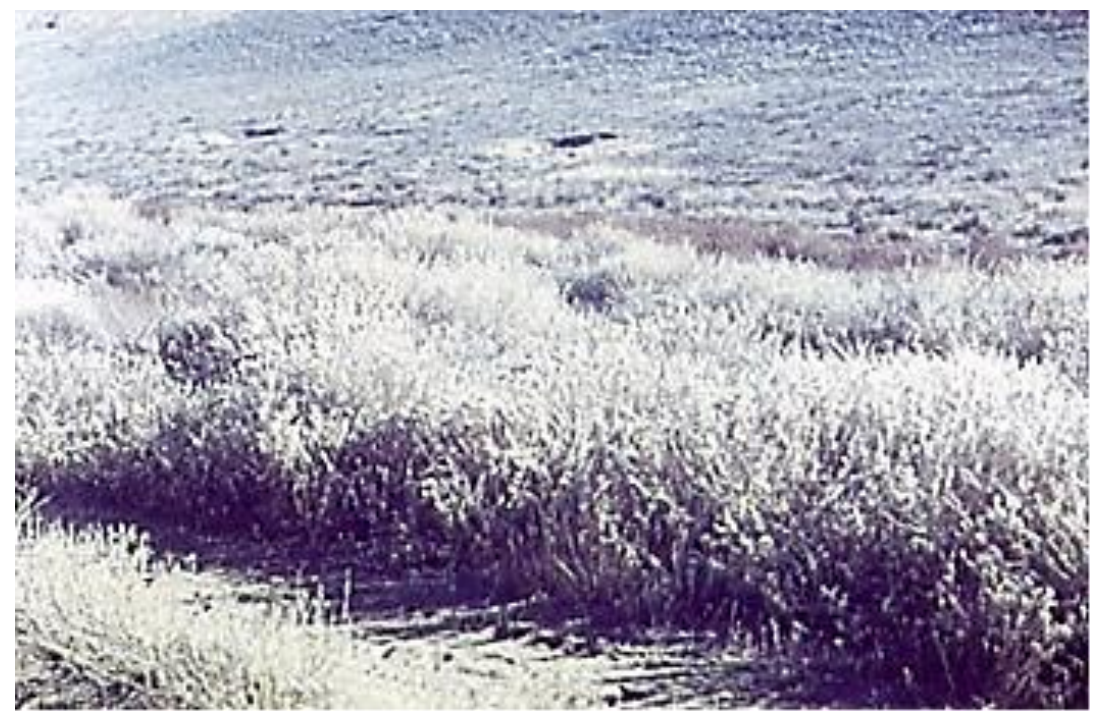

Рис. 3. Заросли терескена Эверсманна Krascheninnikovia ewersmanniana на Северном чинке Устюрта, в Северном

Приаралье. Фото Н. И. Дзюбенко, 2003.

Fig. 3. Thickets of Krascheninnikovia ewersmanniana at the North Ustyurt chink in the North Aral Sea Region.

Photo by N. I. Dzyubenko, 2003.

Ученые ВИР всегда уделяли этим исследованиям первостепенное внимание. В 1920 г. Бюро, переименованное в Отдел по прикладной ботанике и селекции Сельскохозяйственного ученого комитета, возглавил Н. И. Вавилов, организовавший стройную систему изучения кормовых растений, в том числе засухоустойчивых. Важным звеном в ней явилась организация Центральной генетической и селекционной станции в Детском Селе в 1921 г., где соратники Н. И. Вавилова провели фундаментальные исследования засухоустойчивости пустынных растений, в том числе кормовых. Огромный вклад в развитие теории и практики физиологии пустынных растений внес выдающийся ученый, заведующий агрометеорологическим сектором ВИР профессор Н. А. Максимов.

В 1923 г. по инициативе Н. И. Вавилова во Всесоюзном институте растениеводства была организована лаборатория физиологии растений, первым руководителем которой был назначен Н. А. Максимов. В докладе, сделанном им на научном совете Ин- ститута опытной агрономии в ноябре 1923 г., среди основных задач лаборатории были сформулированы глубокие исследования таких важных признаков, как морозоустойчивость и засухоустойчивость. Для выполнения поставленных задач новый руководитель привлек к работе молодых ученых И. И. Туманова, в последствии членакорреспондента АН СССР, Ф. Д. Сказкина, в дальнейшем академика Академии педагогических наук, В. И. Разумова, в последствии члена-корреспондента ВАСХНИЛ, Т. В. Олейникову, в дальнейшем доктора биологических наук, и многих других (Razumov et al., 1968; Pavluchin, 1994).

В период с 1924 по 1935 гг. теория засухоустойчивости, сформулированная Н. А. Максимовым и И. И. Тумановым, бурно развивалась. В 1926 г. вышла в свет монография Н. А. Максимова «Физиологические основы засухоустойчивости растений», получившая большую известность за рубежом (Maximov, 1926). 
В начале XX века в биологии господствовала теория засухоустойчивости А. Шимпера, в которой основным признаком засухоустойчивости считалась ксероморфная структура растения. Степень засухоустойчивости определялась по интенсивности транспирации, причем считалось, что у ксерофитов интенсивность транспирации должна быть пониженной. Н. А. Максимов обосновал и провел эксперименты по изучению завядания растений в лабораториях ВИР в Детском Селе, доказавшие, что в основе засухоустойчивости, как и морозостойкости, лежат физико-химические процессы состояния протоплазмы клеток пустынных растений. Главным звеном в механизме засухоустойчивости оказалось осмотическое давление клеточного сока, а не транспирация, как было принято считать ранее. У многих ксерофитов интенсивность транспирации была выше, чем у мезофитов (Maximov, 1917, 1926, 1931, 1952, by Dzyubenko, Soskov, 2014, p. 274). Как отмечал Н. А. Максимов (Maximov, 1952, bу Dzyubenko, Soskov, 2014), осмотическое давление у ксерофитов всегда больше, чем у мезофитов. У растений засушливых мест обитания осмотическое давление выше, причем наблюдается прямая зависимость: чем меньше запасы влаги, тем выше осмотическое давление. Например, кохия простертая относится к растениям более ксерофильного характера, поскольку завядание у нее начинается при потере $30-40 \%$ всей содержащейся в ней воды, а, например. недотрога завядает уже при потере 1-2\% влаги. Почвы пустынь, из-за процессов выветривания и недостаточного вымывания образующихся солей, всегда оказываются засоленными, поэтому растениям приходится преодолевать осмотическое давление почвенного раствора. Это еще одна из причин высокого осмотического давления растений аридной зоны. По данным Н. А. Максимова, осмотическое давление у кохии простертой в два раза больше, чем у люцерны. Опыты И. И. Туманова, проведенные в 1926-1928 гг. (Razumov et al, 1968), показали, что под влиянием условий среды анатомические признаки растений могут изменяться. Растения, выращенные в условиях недостаточного увлажнения, имеют более ксероморфное анатомическое строение. Степень ксероморфности тканей зави- сит главным образом от продолжительности обезвоживания клеток. Как и у ксерофитов, интенсивность транспирации у таких растений была высокой. При изучении явления завядания у засухоустойчивых и неустойчивых форм культурных растений было показано, что растения, перенесшие завядание, становятся более засухоустойчивыми. Важной тематикой было изучение влияния атмосферной засухи, для чего была сконструирована в лаборатории специальная суховейная установка, которую удалось эвакуировать в годы Великой Отечественной войны из Детского Села, оккупированного гитлеровскими войсками.

Теория засухоустойчивости Н. А. Максимова получила всеобщее признание в нашей стране и за рубежом и явилась фундаментом для развития агроэкологической физиологии растений. За свои разработки Н. А. Максимов в 1929 г. был удостоен Государственной премии СССР. Изучение засухоустойчивости кормовых растений было развернуто не только в стенах ВИР, но и на многочисленных опытных станциях. Исследование засухоустойчивости и водного режима растений в 1932 и 1933 гг. были продолжены физиологами на Среднеазиатской и Степной опытной станциях. Фундаментальные теоретические и практические исследования по изучению засухоустойчивости были выполнены на Репетекской песчанопустынной станции, где ученые изучали псаммофиты песчаной пустыни Каракум (by Dzyubenko, Kochegina, 2016, pp. 11, 12) и в Азербайджанском отделении ВИР на Апшеронском полуострове. После ухода Н. А. Максимова с поста заведующего лабораторией физиологии ВИР в 1933 г. эту работу возглавил И. И. Туманов. В 1940 г. он опубликовал монографию «Физиологические основы зимостойкости культурных растений» (Tumanov, 1940), выполненную на основе исследований, проведенных на Хибинской опытной станции ВИР на Кольском полуострове, а также на Степной, Кубанской, Среднеазиатской опытной станциях. Изучение засухо- и солеустойчивости пустынных и полупустынных растений было продолжено в последующие послевоенные годы. Особенно интенсивно эта работа проводилась с середины 60-х годов прошлого века, когда штат лаборатории физиологии 
был значительно увеличен. Это позволило организовать в ВИР три лаборатории, занимающихся вопросами физиологии растений: лабораторию устойчивости растений к морозу, засухе, засоленности почвы; роста и развития сельскохозяйственных растений; фотосинтеза культурных растений. Сотрудниками лаборатории устойчивости растений под руководством доктора биологических наук, профессора Г. В. Удовенко в течение нескольких десятилетий проводили фундаментальную разработку методов и приемов диагностики уровня устойчивости растений к различным стрессорным воздействиям: засухе, жаре, засолению и низким температурам (Udovenko et al., 1970, 1976; Udovenko, 1977). В дальнейшем коллективом физиологов было создано методическое руководство «Диагностика устойчивости растений к стрессовым воздействиям» (Drozdov et al.,1988), на основе которого были разработаны методические рекомендации для оценки устойчивости многолетних кормовых растений.

Так, изучением коллекции многолетних кормовых злаков - житняка и новой культуры ломкоколосника ситникового - в течение многих лет занималась А. В. Бухтеева, старший научный сотрудник отдела ГР многолетних кормовых культур. Изучению водного режима и некоторых других биологических свойств видов житняка была посвящена ее статья «О засухоустойчивости житняка сибирского и житняка гребневидного» (Bukhteeva, 1971, by Bukhteeva et al., 2016, p. 250). Сотрудники отдела кормовых культур ВИР во главе с заведующим отделом, доктором сельскохозяйственных наук, профессором П. А. Лубенцом, а также специалисты А. И. Иванов, Ю. И. Кириллов, Н. А. Мухина, А. В. Бухтеева и другие разработали «Методические указания изучения коллекции многолетних кормовых культур» (Lubenets et al., 1973; Ivanov et al., 1985 by Dzyubenko, Soskov, 2014, pp. 274, 271). Водный дефицит определялся методом завядания, а жаростойкость - по степени проницаемости протоплазмы для электролитов. Устойчивость популяций житняка к засухе оценивалась по способности растений удерживать воду при длительном завядании, выдерживать глубокое обезвоживание тканей и затем восстанавливать запас воды. Было установлено, что наибольшая водоудерживающая способность свойственна молодым растениям, которые не только восстанавливают потерянный запас воды, но даже превышают его за счет восполнения водного дефицита, имевшегося у них ко времени начала опыта. К моменту цветения она значительно снижается. У популяций житняка гребневидного различия в водоудерживающей способности постепенно уменьшаются от фазы колошения к созреванию семян. У житняка сибирского эти различия очень резко уменьшаются при переходе растений к цветению. Популяции житняка сибирского, хотя существенно и различаются по устойчивости к засухе, но различия между ними не так велики, как между популяциями житняка гребневидного. В составе испытанных образцов у обоих видов имеются как устойчивые, так и неустойчивые к засухе образцы. Эти исследования позволили составить глазомерную шкалу определения реакции растений на засуху, которая была включена в вышеназванные методические указания. Результаты испытания образцов видов житняка и ломкоколосника ситникового на устойчивость к засолению и засухе были опубликованы в совместной разработке сотрудников нескольких отделов ВИР: Л. А. Семушиной, А. В. Бухтеевой, А. Г. Морозовой (Semushina et al., 1978). Было выяснено, что ксероморфизм у житняка проявляется слабо, но растения при значительном содержании хлора (до 0,145\%) в корнеобитаемом слое развиваются вполне нормально. При этом житняк выдерживает весьма значительное засоление. Некоторые популяции житняка концентрируют до 1/3 солей в корнях (образец к-37513), другие преимущественно в надземной массе (образец к-37510). Большое количество солей в органах растений свидетельствует об их способности к рассолению почвы. Популяции житняка солонцовых местообитаний представляют собой ценный исходный материал с закрепленным свойством солеустойчивости, который можно отобрать непосредственно из естественных условий с засоленных местообитаний. Но более эффективно произвести оценку коллекции на этот признак в сочетании с лабораторными методами и таким образом выявить исходный материал, который бы сочетал свойство 
устойчивости с высокой продуктивностью зеленой массы и семян. У всех трех видов житняка обнаруживаются как высокоустойчивые, так и слабоустойчивые популяции.

В 1990 г. были изданы методические указания «Определение засухоустойчивости многолетних кормовых злаков по депрессии роста проростков в растворах осмотиков», разработанные Н. Давуд под редакцией доктора с.-х. наук В. И. Буренина, кандидата биологических наук Н. Н. Кожушко. Автор применил модификацию метода прорастания семян в растворе сахарозы для оценки засухоустойчивости кормовых злаков житняка и костреца безостого (Daud, 1990). Образцы ранжировали по группам засухоустойчивости в зависимости от степени снижения длины главного корешка при прорастании в растворе сахарозы по сравнению с контролем (на воде) и сравнивали со стандартом. Экспериментально было установлено, что образцы житняка и костреца дифференцировались по засухоустойчивости наиболее четко при концентрации $14 \%$ (осмотическое давление 1,2 МПа).

Исследования по засухоустойчивости кохии простертой в ВИР были выполнены Н. С. Цибковской и С. Х. Хусаиновым (Cibkovskaya, Khusainov, 1987, by Dzyubenko, Soskov, 2014, p. 282). Авторы разработали методику определения засухоустойчивости образцов кохии простертой в лабораторных условиях по всхожести семян в $14,9 \%$ растворе сахарозы для первичной оценки засухоустойчивости на ранних этапах развития растений. В результате выделены четыре группы засухоустойчивости: I - высокоустойчивые, прорастание семян по нижней границе доверительного интервала, выше 75\%; II - устойчивость выше средней, прорастание - 51-75\%; III - среднеустойчивые, прорастание - 26-50\%; IV - неустойчивые, прорастание - 0-25\%.

Высокая степень засухоустойчивости выявлена у образца к-530 из АлмаАтинской области (северотуранский каменистый экотип); устойчивость выше средней - у образца к-431 из Ставропольского края (северотуранский каменистый экотип) и образца к-120, также из Ставропольского края (калмыцкий песчаный экотип). Средняя устойчивость к засухе выявлена у образца к-99 из Кзыл-Ординской области (аральский супесчаный экотип), к неустойчивым отнесен образец к-6 из Актюбинской области (северотуранский каменистый экотип). Кроме того, в камеральных условиях определена засухоустойчивость у 15 образцов аральского супесчаного экотипа и семи - у аральского песчаного экотипа (Cibkovskaya, Khusainov, 1987, by Dzyubenko, Soskov, 2014, p. 282). Среди них выявлено 9 высоко- и среднеустойчивых образцов аральского супесчаного и 6 - аральского песчаного экотипов из Актюбинской области. У 86\% проанализированных способом проростков образцов отмечена прямая связь засухоустойчивости с солеустойчивостью. Высокая засухоустойчивость кохии простертой объясняется глубоко проникающей корневой системой, приспособленной к использованию влаги конденсационных горизонтов (Dzyubenko, Soskov, 2014), а также морфофизиологическими особенностями и принадлежностью ее к кохиоидному C4 типу фотосинтеза. Большинство засухоустойчивых образцов являются одновременно и солеустойчивыми. Оценку солеустойчивости кохии простертой способом проращивания семян изучали Л. А. Семушина и А. Г. Морозова (Semushina, Morozova, 1975, 1979, by Dzyubenko, Soskov, 2014, p. 278). Были выделены группы устойчивости к засолению: I- слабоустойчивые, процент (\%) к контролю от 0 до 30 ; II - среднеустойчивые, 31-60; III устойчивые, свыше $60 \%$. Авторы проводили определение предельных концентраций растворов солей, при которых семена кохии простертой и других пустынных кормовых растений еще прорастают. Для кохии таким пределом оказалось засоление 20-25 атм. Солеустойчивость кохии оказалась выше, чем у кейреука и камфоросмы, житняка и ломкоколосника, но ниже, чем у саксаула, семена которого прорастали даже при засолении 30 атм и выше (Semushina, 1981). В порядке убывания солеустойчивости в ряду пустынных кормовых растений они располагались следующим образом: саксаул, кохия, кейреук, камфоросма, ломкоколосник, житняк. В 1981 г. ученые изучали солеустойчивость 153 образцов кохии простертой, относящихся к 9 экотипам (Soskov, Semushina, 1981, by Dzyubenko, Soskov, 2014 , p. 280). Высокоустойчивые к засолению образцы были обнаружены у 3-х эко- 
типов: аральского супесчаного, аральского песчаного и тяньшанского глинистого. В изученном северотуранском солонцовом экотипе не было высокоустойчивых к засолению образцов. Наибольшее количество устойчивых к засолению образцов найдено среди аральского супесчаного экотипа. Среднеустойчивыми к засолению оказались образцы, относящиеся к южноказахстанскому песчаному, ферганскому каменистому и северотуранскому солонцовому экотипам. Образцы, собранные в местах сильного засоления, и в лабораторных условиях сохраняли высокую солеустойчивость.

\section{Изучение солеустойчивости люцерны}

Естественным полигоном для изучения солеустойчивости бобовых культур послужила зона экологического бедствия Аральского моря. Отделом ГР многолетних кормовых культур ВИР за последние 20 лет было проведено более 10 экспедиций по изучению и сбору растений, прошедших естественный отбор на соле- и засухоустойчивость. Так, солеустойчивые образцы люцерны посевной, солеустойчивые и корнеотпрысковые формы ценного вида люцерны $M$. trautvetteri, а также других дикорастущих видов бобовых растений были собраны в районе экстремального засоления Северного Приаралья. На территории Казахстана произрастает более 100 многолетних дикорастущих бобовых растений, из них 32 вида являются экономически значимыми, а 12 наиболее адаптированы к почвенно-климатическим условиям зоны экологической катастрофы Аральского моря. Были выявлены территории с высоким уровнем засоления почв, на которых сосредоточено большое видовое и внутривидовое разнообразие дикорастущих видов бобовых растений из родов Medicago L., Astragalus L., Melilotus Adans и других. В район обследования входили также горы Мугоджары, плато Устюрт. Обследование показало, что в этом районе находится мощный очаг интрогрессивной гибридизации. В очаге соприкасаются ареалы видов Medicago coerulea, M. sativa (культурные и сорно-полевые формы), M. falcata, M. difalcata Sinsk. (Dzyubenko et al., 2001a, b). Популяции M. trautvetteri расселены в обширном ареале $M$. falcata и зачастую произрастают в одном фитоценозе рядом с другими видами, в этом случае наблюдается процесс гибридизации. Гибриды по фе- нотипу напоминают $M$. varia, их идентификация в полевых условиях вызывает трудности. Чистые популяции $M$. trautvetteri c диплоидным набором хромосом, произошедшие от спонтанного скрещивания диплоидных видов $M$. coerulea и $M$. difalcata, встречаются чрезвычайно редко (имеют точечные ареалы) в местах сильной естественной изоляции вблизи очагов интрогрессии. Среди маркерных признаков этих популяций - выровненность по синецветковости и ряд других. В результате обследования 87 участков $M$. trautvetteri была обнаружена на 39 участках (45,9\%). Был выделен 51 участок с повышенным засолением почв от 0,3 до17,0 $\mu \mathrm{h}$ [1:5], среди которых на 29 участках была обнаружена $M$. trautvetteri. Кроме того, на пяти участках с максимальным засолением от 6,0 до 15,0 $\mu \mathrm{h}$ [1:5] растения росли и развивались без явных признаков угнетения. Для засоленных почв аридной и других зон возделывания был собран ценный исходный материал для селекции сортов люцерны пастбищного типа.

На протяжении почти двадцати лет проводятся совместные исследования ВИР и ВНИИ сельскохозяйственной микробиологии по солеустойчивости и созданию новых высокопродуктивных и высокоустойчивых к засолению сортов многолетних кормовых культур при использовании умеренного галотолерантного вида многолетних бобовых растений Medicago sativa. Сборы в природных популяциях люцерны и ее симбионтов, проведенные совместно с ВНИИ сельскохозяйственной микробиологии (Roumiantseva et al., 2015; Belova et al., 2005), позволили установить, что микросимбионты, образованные при взаимодействии клубеньковых бактерий Sinorhizobium meliloti с растением-хозяином люцерной посевной существенно повышают устойчивость растений к этому стрессовому фактору. Был выявлен значительный полиморфизм штаммов по локусам het-генов, вовлеченных в механизм формирования солеустойчивости у ризобий. Отбор симбиотических пар, проявляющих повышенную солеустойчивость, проводится по признаку контрастной специфичности. Использованный подход комплексного анализа генотипических и симбиотических признаков микро- и макросимбионтов позволяет отбирать высокоэффективные симбиотические системы, устойчивые к действию стрессфакторов. По результатам сбора почвенных 
образцов, содержащих ризобиум в зоне Приаралья сотрудниками ВИР, во ВНИИ сельскохозяйственной микробиологии была создана коллекция штаммов микроорганизмов азотфиксирующих бактерий (Ibragimova et al., 2006).

Другое современное направление изучения физиологических механизмов галотолерантности растений - использование молекулярного маркирования генов, определяющих устойчивость к солевому стрессу (Dzyubenko et al., 2010, by Dzyubenko, Kochegina, 2016, p. 29). Так, для люцерны посевной Medicago sativa был выявлен ген $S r l k$, контролирующий устойчивость к засолению, проведено его молекулярное маркирование (Dzyubenko et al., 2011; Vishnevskaya et al., 2014). Реакция растений на абиотический стресс включает три этапа: распознавание стрессовой ситуации рецепторными белками, встроенными в клеточную мембрану; передача сигнала о воздействии неблагоприятных факторов; активация экспрессии генов, обеспечивающих ответную защитную реакцию.

Для модельного бобового растения $M$. truncatula Gaertn. опубликована нуклеотидная последовательность гена Srlk (saltinduced receptor-like kinase), который играет ведущую роль на первых двух этапах механизма генетического контроля солеустойчивости. Этот ген кодирует сигнальный белок RLK - рецепторную протеинкиназу (receptor-like proteinkinase), встроенную в клеточную мембрану. Далее белок RLK передает сигнал о повышенной концентрации ионов $\mathrm{Na}$ в межклеточном пространстве посредством Srlk в цитоплазму клетки. На третьем этапе происходит активация экспрессии генов, обеспечивающих каскад биохимических процессов по ответной защитной реакции на солевой стресс. Мутации в структурной части $S r l k$ изменяют последовательность аминокислот гена или приводят к стоп-кодонам (TILLING Srlkmutants). Метод молекулярной генетики, получивший название по первым буквам английского названия «TILLING» (Targeting Induced Local Lesions in Genomes) - новый метод «обратной» генетики, работающий по принципу «от генотипа к фенотипу» - поиск индуцированных локальных нарушений в геномах. Эти изменения в условиях солевого стресса достоверно и существенно изменяют длину, массу корней, массу надземной части растения, способность растения к образованию клубень- ков. Бобовые растения имеют сходную организацию генома, поэтому данные, полученные для модельного растения M. truncatula, были положены в основу при изучении естественного полиморфизма нуклеотидной последовательности гена Srlk у различных видов Medicago из коллекции ВИР. Для оценки устойчивости к засолению исследовали образцы люцерн разного происхождения - посевной (сорт 'Надежда'), к-40812, к-25782 (сорт 'Тибетская'); изменчивой к-27062 (сорт 'Северная гибридная'); посевной дикорастущей к-8958, к-33743; Траутфеттера дикорастущей к38553, к-35023; серповидной дикорастущей к-1674, к-440050, к-36748; голубой дикорастущей к-12821, к-36116.

Был осуществлен поиск сходной нуклеотидной последовательности гена Srlk, опубликованной для модельного объекта M. truncatula, для вида M. sativa в базе данных TIGR Plant Assemblies. В геноме $M$. sativa была выявлена единственная достоверно сходная последовательность CO515446, кодирующая рецепторную протеинкиназу, процент сходства которой с геном Srlk для M. truncatula составил 97\%. Это свидетельствует о консервативности гена Srlk среди видов Medicago. На этой основе была сконструирована серия геноспецифичных праймеров (коротких одноцепочечных фрагментов нуклеиновой кислоты, комплементарных ДНК-матрице, используемых для затравки) для использования в полимеразно-цепной реакции с геномной ДНК различных видов люцерны. Фрагмент последовательности гена Srlk был проанализирован у 12 образцов $M$. sativa, при этом было выявлено 30 нуклеотидных замен (SNP Single nucleotide polymorphism), 19 из которых продемонстрировали полиморфизм у различных образцов. Для сортов 'Тибетская' и 'Надежда' выявлены три несинонимичных SNP, отличающие их от остальных генотипов, изменяющих аминокислотный состав кодируемого белка, что может иметь особую важность при создании солеустойчивых сортов люцерны. Выявленные SNP, приводящие к изменению аминокислотной последовательности рецепторной киназы у солеустойчивых и солечувствительных сортов важны для создания на их основе CAPSмаркеров (cleaved amplified polymorphic sequence - расщепленные амплифицированные полиморфные последовательности) 
для молекулярного маркирования генов солеустойчивости.

\section{Международная деятельность}

Результаты изучения ресурсов многолетних кормовых культур были представлены на международной арене в виде статей, докладов и выступлений. Так, в Германии на Международной конференции по пастбищным культурам (Dzyubenko, Vishnyakova, 1995), в США по изучению кормовых растений в зоне экологической катастрофы Аральского моря (Dzyubenko, 1997; Waldron et al., 2000, by Dzyubenko, Kochegina, 2016, p. 30), на Международной конференции в Дотнуве по методическим подходам к оценке генетического разнообразия при интродукции (Dzyubenko, Shvytov, 1997), в докладах Международной рабочей группы по кормовым культурам IPGRI в Италии и Португалии (Chapurin et al., 1995; Dzyubenko, 2000), в Китае на VIII Международном конгрессе по пастбищам (Dzyubenko, 2008) и Симпозиуме по кормовым культурам и биотопливу (Dzyubenko N., Dzyubenko E., 2012). На Международном конгрессе по кормовым угодьям в Аргентине был представлен доклад по пастбищным засухо- и солеустойчивым растениям Центральной Азии (Dzyubenko, 2011, by Dzyubenko, Kochegina, 2016, p. 31). Отдел ГР многолетних кормовых культур ВИР на протяжении тридцати лет успешно сотрудничал по привлечению ресурсов соле- и засухо-устойчивых культур с лабораторией Пастбищ Министерства сельского хозяйства США (г. Логан, штат ЮТА), международным центром засухоустойчивых культур ICARDA, AgroResearch (Генбанк Новой Зеландии), CLIMA (Австралия).

\section{Заключение}

На современном этапе вопросы сохранения и изучения растительных ресурсов аридных регионов нашей страны приобретают особое значение. Нарастающий экологический кризис планеты (загрязнение земного, околоводного и водного пространств, водный дефицит) ведет к быстрому сокращению биоразнообразия флоры. В этих условиях возрастает ценность образцов мировой коллекции засухоустойчивых культур и их диких родичей, в том числе кормовых ксеро- и галофитов.

За более чем 100-летний период исследований сотрудники ВИР создали и сохранили ценнейшую коллекцию генетических ресурсов засухо- и солеустойчивых кормовых культур и их диких родичей и внесли свой теоретический и практический вклад в решение проблем устойчивости сельскохозяйственных культур к стрессовым факторам и сохранения кормовых угодий засушливых зон России и стран СНГ.

\section{References/Литература}

Belova V. S., Ibragimova M. V., Kurchak O. N., Onishchuk O. P., Andronov E. E., Roumiantseva M. L., Dzyubenko N. I., Simarov B. V. Sinorhizobium meliloti - Medicago sativa symbiosis beneficial for saline environment // Symposium and postgraduate course agro-biotechnology focused on root-microbe systems. Kaunas, Lithuania. May 20-27. 2005, p. 14.

Bukhteeva A. V. Karyiosystematic study of crested wheatgrass - Agropyron cristatum subsp. pectinatum (Bieb) Tzvel. ((The Gene Bank of Forage Crops for Breeding) // Bulletin of applied botany, genetics and plant breeding, 1988, vol. 120, pp. 83-89 [in Russian] (Бухтеева А. В. Кариосистематические исследования житняка гребневидного - Agropyron cristatum subsp. pectinatum (Bieb) Tzvel. «Генофонд кормовых растений и его использование в селекции» // Тр. по прикл. бот., ген. и сел. 1988. Т. 120. C. 83-89).

Bukhteeva A. V., Maly'shev L. L., Dzyubenko N. I., Kochegina A. A. Genetic resources of wheat- grass Agropyron Gaertn. [in Russian] (Буxmeeва А. В., Мальишев Л. Л., Дзюбенко Н. И., Кочегина $A$. A. Генетические ресурсы житняка Agropyron Gaertn. СПб.: ВИР, 2016. 268 с.).

Burenin N. I., Ivanov A. I., Soskov Yu. D., Daud Naser. Drought resistant fodder plants // Bulletin of applied botany, genetics and plant breeding (The Gene Bank of Forage Crops for Breeding), 1988, vol. 120, pp. 5-11 [in Russian] (Бyренин Н. И., Иванов А. И., Сосков Ю. Д., Давуд Н. Засухоустойчивые кормовые растения // Тр. по прикл. бот., ген. и сел. «Генофонд кормовых растений и его использование в селекции». 1988. Т. 120. С. 5-11).

Chapurin V. F., Chapurin V. F., Soskov Yu. D.,

Bukhteeva A. V., Dzyubenko N. I. Resources of perennial forage at the All-Russian Researcher Institute of Plant Industry (VIR) // Report of a working group on Forages, 5th meeting 31.032.04 1995. IPGRI, Sophia - Rome, Italy,1995, pp. $87-89$. 
Daud Naser. Methodological Guidelines. The definition of drought resistance of perennial forage grasses on depressive-seedling growth in osmotic solutions. Leningrad: VIR, 1990, 12 p. [in Russian] (Давуд H. Методические указания. Определение засухоустойчивости многолетних кормовых злаков по депрессии роста проростков в растворах осмотиков. Л.: ВИР, 1990. 12 c.).

Drozdov $S$. N. et all. Diagnosis of plant resistance to stresses. Methodological guidance / Ed. by Udovenko G.V. Leningrad: VIR, 1988, 228 p. [in Russian] (Дроздов С. Н. и др. Диагностика устойчивости растений к стрессовым воздействиям. // Методическое руководство. Л.: ВИР, 1988. 228 с.).

Duk $O$. V. Combining ability of alfalfa samples in the North Caucasus // Author. diss. ... kand. s.hk. nauk. Leningrad: VIR, 1989, 17 p. [in Russian] (Дук О. В. Комбинационная способность образцов люцерны в условиях Северного Кавказа // Автореф. дисс. ... канд. с.-х. наук. Л.: ВИР, 1989. 17 с.).

Dzyubenko N. I. Genetic resources of rangeland plants for extreme environment conditions // Multifunctional Grasslands in a Changing World. Proceedings of the XXI International Grassland Congress/YIII International Rangeland Congress, 2008, Hohhot, China, vol. 2, pp. 443-445.

Dzyubenko N. I. Perennial fodder crops in the collection of Vavilov institute: taxonomic diversity and breeding value// Report of a Working Group on Forages. IPGRI, Portugal, 2000. pp. 137-139.

Dzyubenko N. I. Population-genetic basis for improving and stabilizing the productivity of alfalfa seed// Author. diss. ... dokt. biol. nauk. Leningrad: VIR. 1995. 45 p. [in Russian] (Дзюбенко Н. И. Популяционно-генетические основы повышения и стабилизации семенной продуктивности люцерны // Автореф. дисс. ... докт. биол. наук. Л.: ВИР, 1995. 45 с.).

Dzyubenko N. I. Vavilov collection of the world's genetic resources of cultivated plants - Russia strategic framework crop // Selection, seed and genetic, 2015, no. 5, pp.16-21[in Russian] (Дзюбенко Н. И. Вавиловская коллекция мировых генетических ресурсов культурных растений - стратегическая основа растениеводства России // Селекция, семеноводство и генетика. 2015. № 5. С.16-21).

Dzyubenko N. I., Dzyubenko E. A., Khusainov A. Expeditionary Search and salt-tolerant weed forming shapes Medicago trautvetteri Sumn. in the zone of ecological disaster of Northern Aral Sea region // Intern. Scientific and Practical. Conf. "Genet. Resources of Cult. Plants", 13-16 November, 2001, St. Petersburg: Tez. rep. St. Petersburg: VIR, 2001a, pp. 26-27 [in Russian] (Дзюбенко Н. И., Дзюбенко Е. А., Хусаинов $C . X$. Экспедиционный поиск солеустойчивых и корнеотпрысковых форм Medicago trautvetteri Sumn. в зоне экологической катастрофы Северного Приаралья // Межд. науч.практ. конф. «Ген. ресурсы культ. растений», 13-16 ноября 2001, СПб. Тез. докл. СПб.: ВИР, 2001a. С. 26-27).

Dzyubenko N. I., Dzyubenko E. A., Khusainov A. Methodological bases of the expedition search and collection of salt-resistant populations of wild species of legumes in a zone of ecological disaster of Northern Aral Sea region // Intern. Scientific and Practical. Conf. "Genet. Resources of Cult. Plants", 13-16 November, 2001, St. Petersburg: Tez. rep. St. Petersburg: VIR, 2001b, pp. 27-28 Ibid, pp. 27-28 [in Russian] (Дзюбенко Н. И., Дзюбенко Е. А., Хусаинов $C$. $X$. Методические основы экспедиционного поиска и сбора солеустойчивых популяций дикорастущих видов бобовых растений в зоне экологической катастрофы Северного Приаралья // Межд. науч.-практ. конф. «Ген. ресурсы культ. растений», 13-16 ноября 2001, СПб. Тез. докл. СПб.: ВИР, 2001б, C. 27-28).

Dzyubenko N. I., Dzyubenko E. A. N. I. Vavilov and his collaborators in organiza-tion of VIR forage crop collection and forage crop department // Proceedings on applied botany, genetics and breeding, 2012, vo1. 169, pp. 161-179 [in Russian] (Дзюбенко Н. И., Дзюбенко Е. А. Н. И. Вавилов и его сподвижники в становлении работы с кормовыми культурами в ВИРе (к 100-летию работы с кормовыми культурами в ВИРе) // Тр. по прикл. бот., ген. и сел. 2012. T. 169. C. 161-179).

Dzyubenko N. I., Kochegina A. A. N. I. Vavilov and scientists of the VIR role in the desert reclamation // Proceedings on applied botany, genetics and breeding, 2016, vol. 177, iss. 1, pp. 5-34 [in Russian] (Дзюбенко Н. И., Кочегина А. А. Роль Н. И. Вавилова и ученых ВИР в освоении пустынь // Тр. по прикл. бот., ген. и сел. 2016. Т. 177. Вып 1. С. 5-34).

Dzyubenko N. I., Shvytov I. A. Methodological approaches for evaluation of plant genetic diversity during introduction // Plant Breeding - theories, achievements and problem. Intern. conf. Dotnuva, 1997, pp. 182-188.

Dzyubenko N. I., Soskov Yu. D. Genetic resources of kohia stretched (Kochia prostrata (L.) Shrad). St Peterburg: VIR, 2014, 336 p. [in Russian] (Дзюбенко Н. И., Сосков Ю. Д. Генетические ресурсы кохии простертой (Kochia prostrata (L.) Shrad). СПб.: ВИР, 2014. 336 c.).

Dzyubenko N. I., Vishnevskaya M. S., Pavlov A. V., Dzyubenko E. A., Potokina E. K. Nucleotide polymorphism of gene Srlk, controlling resistance to salinity from alfalfa (Medicago sativa L.) // In sb.: Mnogofaktornoje adaptivnoje kormoproyzvodstvo, Moscow, 2011, pp. 231-241 [in Russian] (Дзюбенко $H$. И., Вишневская М. С., Павлов А. В., Дзюбенко E. A., Потокина $E$. K. Нуклеотидный по- 
лиморфизм гена $S r l k$, контролирующего устойчивость к засолению у люцерны посев$\begin{array}{lllll}\text { ной (Medicago sativa L.). // B } & \text { // }\end{array}$ сб.: Многофакторное адаптивное кормопроизводство. М., 2011. С. 231-241).

Dzyubenko N. I., Vishnyakova $M$. A. Intraspecific variability of seed productivity character in alfalfa // III Intern. Herbage Seed Conf., Halle, Germany, 1995, p. 54.

Ibragimova M. V., Roumiantseva M. L., Onischuk O. P., Belova V. V., Kurchak O. N., Andronov E. E., Dzyubenko N. I., Simarov B. V. The symbiosis of nodule bacteria Sinorhizobium meliloti with alfalfa Medicago sativa in conditions of salinity // Microbiologya, 2006, vol. 75, no. 1, pp. 94-100 [in Russian] (Ибрагимова М. В., Румянцева М. Л., Онищук О. П., Белова В. В., Курчак О. Н., Андронов Е. Е., Дзюбенко Н. И., Симаров Б. В. Симбиоз клубеньковых бактерий Sinorhizobium meliloti с люцерной Medicago sativa в условиях засоления // Микробиология, 2006. Т. 75. № 1. C. 94-100).

Ivanov A. I. Alfalfa. Subgenus Falcago (Reichb.) Grossh. Genus Medicago L. // Author. Diss. ... doct. s.-hk. nauk. Leningrad: VIR, 1977, 32 p. [in Russian] (Иванов А. И. Люцерна. Подрод Falcago (Reichb.) Grossh. рода Medicago L. // Автореф. дисс. ... докт. с.-х. наук. Л., 1977. 32 c.).

Ivanov A. I., Dzyubenko N. I., Bukhteeva A. V. Conducting self-pollination, hybridization, account self-fertility and auto tripping alfalfa // Methodological instructions. Leningrad: VIR, 1982, 16 р. [in Russian] (Иванов А. И., Дзюбенко Н. И., Бухтеева А. В. Проведение самоопыления, гибридизации, учета самофертильности и автотриппинга у люцерны / Методические указания. Л.: ВИР, 1982. 16 с.).

Kuznetsov $V$. A. The ranges of the geographical distribution of the most important forage crops of clover and alfalfa // Bulletin of applied botany and plant-breeding, 1926, vol. 16, iss. 1. p. 87. [in Russian] (Кузнецов В. А. Ареалы географического распространения важнейших кормовых видов клевера и люцерны // Тр. по прикл. бот. и сел. 1926. Т. 16. Вып. 1. С. 87).

Lubenets $P$. A. Alfalfa, its species composition and selection methods // Author. diss. ... doct. s-kh. nauk. SPb: VIR, 1953, 36 p. [in Russian] (Лyбенеи П. А. Люцерна, ее видовой состав и методы селекции // Автореф. дисс. ... докт. с.-х. наук. Л.: ВИР, 1953. 36 с.).

Lubenets P. A., Ivanov A. I., Kyrillov Ju. I., Mukhina N. A., Bukhteeva A. V. et all. Methodical instructions for the study of the collection of perennial forage grasses [in Russian] (Лубенеи П. А., Иванов А. И., Кириллов Ю. И., Мухина H.A., Бухтеева A. В. и др. Методические указания по изучению коллекции многолетних кормовых трав. Л.: ВИР, 1973. 37 с.).

Maly'sheva N. Yu. Ecology of pollination and pollinators of alfalfa (Medicago ssp.) in the North- ern Aral Sea region// Author. diss. ... cand. s.kh. nauk. SPb: VIR, 1997, 20 p. [in Russian] (Мальиева Н. Ю. Экология опыления и опылители люцерны (Medicago sp.) в Северном Приаралье // Автореф. дисс. ... канд. с.х. наук. Л.: ВИР, 1997, 20 с.).

Maximov $N$. A. The physiological basis of drought resistance of plants // Application no. 26 to Bulletin of applied botany and plant-breeding. Leningrad, 1926, 436 p. [in Russian] (Максимов $H$. A. Физиологические основы засухоустойчивости растений // Приложение № 26 к Тр. по прикл. бот.и сел. Л.: ВИР, 1926. 436 с.).

Orel L. I., Kazachkovskaya E. B., Semenova E. V., Dzyubenko E. A., Dzyubenko N. I. Method of isolation and characterization of plant types with full sterile female alfalfa / Methodical instructions. Leningrad: VIR, 1991, 26 p. [in Russian] (Орел Л. И., Казачковская Е. Б., Семенова Е. В., Дзюбенко Е. А., Дзюбенко Н. И. Способ выделения и характеристика типов растений с полной женской стерильностью у люцерны / Методические указания. Л.: ВИР, 1991. 26 c.).

Orel L. I., Konstantinova L. N., Dzyubenko N. I., Kazachkovskaya E. B. Express methods of determining fertility embryo sacs alfalfa. Methodical instructions. Leningrad: VIR, 1988, 26 p. [in Russian] (Орел Л. И., Константннова Л. Н., Дзюбенко Н. И., Казачковская Е. Б. Экспресс-методы определения фертильности зародышевых мешков люцерны / Методические указания. Л.: ВИР, 1988. 26 с.).

Orel L. I., Konstantinova L. N., Ogorodnikova $V$. F., Vishnyakova M. A., Dzyubenko N. I., Kazachkovskaya E. B. The selection of alfalfa plants with high fertility ovaries / Methodological instructions. Leningrad: VIR, 1985, 35 p. [in Russian] (Орел Л. И., Константинова Л. Н., Огородникова В. Ф., Вишнякова М. А., Дзюбенко Н. И., Казачковская Е. Б. Отбор растений люцерны с высокой плодовитостью завязей / Методические указания. Л.: ВИР, 1985. 35 c.).

Pavlukhin $Y$ u. S. Maximov Nikolai Alexandrovich // In: Nikolai Ivanovich Vavilov Associates. Researchers of Plant Gene Pool. St. Petersburg: VIR, 1994, pp. 347-363 [in Russian] (Павлухин Ю. С. Максимов Николай Александрович // В кн.: Соратники Николая Ивановича Вавилова. СПб.: ВИР, 1994. С. 347-363). Pavlukhin Yu. S., Kirillov Yu. I. Kuznetsov Vladimir Alexandrovich. // In: Nikolai Ivanovich Vavilov Associates. Researchers of Plant Gene Pool. St. Petersburg: VIR, 1994, pp. 276-289 (Павлухин Ю. С., Кириллов Ю. И. Кузнецов Владимир Александрович // В кн.: Соратники Николая Ивановича Вавилова. СПб.: ВИР, 1994. С. 276-289).

Razumov V. I., Lymar'R. S., Oleynikova T. V., Uglov P. G., Udovenko G. V., Panchenko N. P., Bykov $O$. $V$. Results of research on plant physiology // Bulletin of applied botany, genetics and 
plant breeding, 1968, vol. 39, iss. 2, pp. 70-101 [in Russian] (Разумов В.И., Лимарь Р. С., Олейникова Т. В., Углов П. Г., Удовенко Г. В., Панченко Н. П., Быков О. В. Итоги исследований по физиологии растений // Тр. по прикл. бот., ген. и сел. 1968. Т. 39. Вып 2. С. 70-101).

Regel R. E. The organization and activities of the Bureau of Applied Botany in the first twenty years its existence// Bulletin of applied botany and plant-breeding, 1915, no. 4-5, pp. 327-723 [in Russian] (Регель P. Э. Организация и деятельность Бюро по прикладной ботанике за первое двадцатилетие его существования // Тр. по прикл. бот. и сел. 1915. № 4-5. С. 327-723).

Roumiantseva M. L., Stepanova G. V., Kurchak O. N., Onischuk O. P., Muntyan V. S., Dzyubenko E. A., Dzyubenko N. I., Simarov B. V. The selection of salt-tolerant plants of different types of lucerne and analysis of their morphobiological and symbio-trophical indicators // Selskochoz. Biol., 2015, vol. 50, no. 5, pp. 673678 [in Russian] (Румянцева М. Л., Степанова Г. В., Курчак О. Н., Онишук О. П., Мунтян B. С., Дзюбенко Е. А., Дзюбенко Н. И., Симаров Б. В. Отбор солеустойчивых растений разных видов люцерны и анализ их морфобиологических и симбиотрофных показателей // Сельхоз. биол. 2015. Т. 50. № 5. С. 673-678).

Semushina L. A. Salt tolerance of desert forage plants. // Bulletin VIR, 1981, iss. 108, pp. 5557 [in Russian] (Семушина Л. А Солеустойчивость пустынных кормовых растений //Бюл. ВИР, 1981. Вып. 108. С. 55-57).

Semushina L. A., Bukhteeva A. V., Morozova A. G. Relative salt tolerance of wheat grass and psathyrostachys collections // Bulletin VIR, 1978, iss. 86, pp. 65-68 [in Russian] (Семушина Л. А., Бухтеева А. В., Морозова А. Г. Сравнительная солеустойчивость коллекции житняка и ломкоколосника // Бюлл. ВИР. 1978. Вып. 86. С. 65-68).

Shamsutdinov Z. Sh., Shamsutdinova A. Z., Starshinova $O$. A. The breeding of arid forage plants in the context of the ecotype concept // Intern. sci.pract. e-zine "Arid forage crop", 2013, no. 2(14), pp. 17-30 [in Russian] (Шамсутдинов 3. Ш., Шамсутдинова Э. 3., Стариинова О.
A. Селекция аридных кормовых растений в контексте концепции экотипа // Научнопракт. межд. электр. журн. «Адаптивное кормопроизводство», 2013. №2(14) С. 1730).

Tumanov I. I. Physiological basis of crops frostresistance. Leningrad: Selkhozgiz. 1940. 365 p. [in Russian] (Туманов И. И. Физиологические основы зимостойкости культурных растений. Л.: Сельхозгиз, 1940. 365 с.).

Udovenko $G$. $V$. et all. Methods of evaluating the resistance of plants to adverse environmental conditions. Leningrad: VIR, 1976, 318 p. [in Russian] (Удовенко Г. В. и др. Методы оценки устойчивости растений к неблагоприятным условиям среды. Л.: ВИР, 1976. 318 с.).

Udovenko $G$. $V$. Salt tolerance of crop plants. Leningrad, 1977, 216 p. [in Russian] (Удовенко $Г$. $B$. Солеустойчивость культурных растений. Л., 1977. 216 с.).

Udovenko G. V., Oleynikova T. V., Koghushko N. N., Barashkova N. A. et all. Methods of diagnosis of plant resistance (drought, extraheat- resistance, salt tolerance and frost). Leningrad: VIR, 1970, 74 p. [in Russian] (Удовенко Г. В., Олейникова Т. В., Кожушко Н. Н., Барашкова Н. A. и др. Методика диагностики устойчивости растений (засухо-, жаро-, соле- и морозоустойчивости). Л.: ВИР, 1970. 74 с.).

Vavilov N. I. Global Resources of DroughtResistant Varieties // Report at the All-Union Conference on Fight against Drought. 26.10.3131.10.31, Moscow, 1931, Bull. no. 2 [in Russian] (Вавилов Н. И. Мировые ресурсы засухоустойчивых сортов // Докл. на Всесоюзн. конф. по борьбе с засухой 26-31.10.31. М., 1931. Бюлл. № 2).

Vishnevskaya M. S., Pavlov A.V., Dzyubenko E. A., Dzyubenko N. I., Potokina E. K. Nucleotide Polymorphism of the Srlk Gene That Determines Salt Stress Tolerance in Alfalfa (Medicago sativaL.) // Russian Journal of Genetics, 2014, vol. 50, no. 4, pp. 378-386 [in Russian] (Вишневская М. С., Павлов А. В., Дзюбенко E. А., Дзюбенко Н. И., Потокина Е. К. Нуклеотидный полиморфизм гена $S r l k$, определяющего устойчивость к солевому стрессу у люцерны (Medicago sativa L.) // Генетика. 2014. T. 50. № 4. C. 378-386 


\section{Е. А. Добренков ${ }^{1}$, \\ Л. Г. Семенова ${ }^{1}$, \\ С. Е. Дунаева ${ }^{2}$, \\ Ю. В. Ухатова ${ }^{2}$}

${ }^{1}$ Филиал Майкопская опытная станция Федерального исследовательского центра Всероссийского института генетических ресурсов растений имени Н. И. Вавилова, 385746 Россия,

г. Майкоп

e-mail: dobrenkov72@mail.ru

${ }^{2}$ Федеральный исследовательский центр Всероссийский институт генетических ресурсов растений имени

Н. И. Вавилова, 190000 Санкт-Петербург, ул. Б. Морская д. 42, 44, Россия,

e-mail: dunaevase@mail.ru

\section{Ключевые слова:}

семейство, род, вид, лиана, ежевика, пробирочная культура, полевые условия, адаптивность

Поступление:

02.11 .2016

Принято:

06.03.2017

\section{АДАПТАЦИЯ ПРОБИРОЧНЫХ РАСТЕНИЙ ЕЖЕВИКИ К ПОЛЕВЫМ УСЛОВИЯМ СРЕДЫ}

Актуальность. Выделение продуктивных, с высоким качеством плодов, адаптивных образцов ежевики из генофонда ВИР важно для рационального их размещения, решения различных селекционных программ. Интерес представляла проблема адаптации растений ежевики, полученных из коллекции in vitro, к полевым условиям южного региона России. Материал и методы. Из пробирочной коллекции ежевики ВИР в филиал Майкопская опытная станция ВИР были переданы микрорастения 12-ти образцов в стадии ризогенеза с целью изучения их жизнеспособности в полевых условиях предгорной зоны Северного Кавказа. Исследовали биометрические показатели развития растений в пробирочной культуре и жизнеспособность в почвенных контейнерах. Изучая растения в полевых условиях, отмечали отрастание побегов после зимы, наблюдали за фазами развития растений, оценивали состояние водного режима растений, урожайность, восприимчивость ежевик к воздействию засухи и грибным патогенам. Методики изучения образцов использованы общепринятые. Результаты и выводы. Приживаемость растений, при их пересадке из пробирок в почвенные контейнеры, через 4 месяца составляла от $44 \%$ ('Merton Thornless') до 100\% ('Cascade', 'Logan Thornless', 'Whitford Thornless', 'Young'). При пересадке в естественные условия среды слабо росли только растения сорта 'Bodega Bay'. В экстремальные зимы у образцов 'Whitford Thornless', 'Dirksen Thornless', 'Eldorado', 'Logan Thornless', 'Young' подмерзала только верхняя часть прошлогоднего побега. Стабильно высокоурожайными являются сорта 'Dirksen Thornless', 'Eldorado', 'Evergreen Thornless'. Крупноплодностью и товарностью ягод выделяются сорта 'Dirksen Thornless', 'Eldorado', 'Young'. В полевых условиях после длительного воздействия засухи и жары общее состояние ежевик оценивали на 4,5-5,0 баллов. У относительно устойчивого сорта ('Logan Thornless') оводненность, тургор и водоудерживающая способность листьев были выше, чем у неустойчивого сорта ('Ashton Cross'). Мучнистой росой повреждаются сорта 'Young' и 'Cascade'. Относительно высокую полевую устойчивость к пятнистостям листьев проявляют сорта 'Evergreen Thornless', 'Whitford Thornless'. 


\section{E. A. Dobrenkov' L. G. Semenova ${ }^{1}$, S. E. Dunaeva ${ }^{2}$, Y. V. Ukhatova ${ }^{2}$}

${ }^{1}$ Maikop Experiment Station of the N. I. Vavilov All-Russian Institute of Plant Genetic

Resources,

Maikop, 385746, Russia,

e-mail: dobrenkov72@mail.ru

${ }^{2}$ The N. I. Vavilov

All-Russian Institute

of Plant Genetic Resources,

42, 44, Bolshaya Morskaya str., St. Petersburg,

190000 Russia,

e-mail: dunaevase@mail.ru

Key words:

blackberry, in vitro, field conditions, adaptability

Received:

02.11 .2016

Accepted:

06.03.2017

\section{ADAPTATION OF IN VITRO BLACKBERRY PLANTS TO FIELD ENVIRONMENTS}

Background. Selection of productive, high-quality and adaptive blackberry accessions from the gene pool held by VIR is important for their rational placement, and for solving various tasks of breeding programs. Of particular interest is the problem of survival and development of blackberry plants under field conditions of the southern region of Russia. Material and methods. Microplants of 12 blackberry accessions from VIR's in vitro collection were transferred to Maikop Station at the stage of rhizogenesis to study their viability under field conditions of a foothill zone in the North Caucasus. Biometric indicators of plant development in in vitro culture and viability in soil containers were investigated. Studying ex vitro plants in the field, we noted the regrowth of shoots after the winter, observed the phases of plant development, analyzed fruit quality, assessed the water status of blackberry plants, yield, and susceptibility to the effects of drought and fungal pathogens. To study the accessions, conventional methods were used. Results and conclusions. During severe winters with little snow, the accessions 'Whitford Thornless', 'Dirksen Thornless', 'Eldorado', 'Logan Thornless' and 'Young' had only the upper part of the last year shoot frozen. The accessions 'Dirksen Thornless', 'Eldorado' and 'Evergreen Thornless' were consistently high yielding. Large fruit size and good marketability of berries characterized the varieties 'Dirksen Thornless' and 'Eldorado'. In the field, after prolonged exposure to drought and heat, the general state of blackberries was estimated at 4.5-5.0 points. For drought- and heat-resistant varieties, the water content, turgor and water-holding capacity of the leaves were higher than those of the unstable ones. Powdery mildew in wet years damaged the plants of the varieties 'Young' and 'Cascade'. Relatively high field resistance to leaf spot was shown by the varieties 'Evergreen Thornless' and 'Whitford Thornless'. 


\section{Введение}

В состав полевой коллекции ежевики филиала Майкопской опытной станции входят 22 вида, 10 экоформ, 38 сортов. Из этой коллекции 14 видов (16 видообразцов), собранных на территории Кавказа и Закавказья в экспедициях ВИР, среди которых 5 эндемиков, продублированы в коллекции in vitro отдела биотехнологии ВИР. В in vitro коллекции содержатся также сорта ежевики, в основном поступившие из коллекции in vitro NCGR (Corvallis, USA) в 1995-1996 гг., которых нет в полевой коллекции Майкопской опытной станции и которые могут представить интерес для выращивания в южном регионе России. Пробирочная коллекция ежевик ВИР находится на среднесрочном хранении при замедленном росте микрорастений $\left(4^{\circ} \mathrm{C}\right.$, фотопериод 8 час.) (Dunaeva et al., 2007; 2011). Из этой коллекции в 2008 году были отобраны и переданы в пробирочной культуре 11 сортов ежевики, в их числе бесшипные сорта и 1 малино-ежевичный гибрид для изучения в полевой коллекции филиала Майкопской опытной станции. Каждый образец был представлен несколькими микрорастениями в стадии ризогенеза.

Ежевика - многолетняя культура, на которую воздействует целый комплекс погодных факторов, определяющий основные биологические функции растений (рост, развитие, продуктивность, качество ягод).

Климат предгорной зоны Республики Адыгея относительно теплый и влажный. Зима малоснежная, умеренно-холодная с чередованием морозных периодов и оттепелей. Во второй половине лета практически ежегодно отмечаются засушливые и жаркие периоды разной длительности, поражение растений микозами.

В данном сообщении представлены результаты наблюдений за приживаемостью пробирочных растений к естественным условиям среды, дана оценка комплекса хозяйственно ценных признаков взрослых растений, а также устойчивости к абиотическим и биотическим стресс-факторам, свойственным предгорной зоне Республики Адыгея.

Выделение из генофонда ежевики новых продуктивных, с высоким качеством плодов, адаптивных сортов важно для рационального их размещения, решения различных селекционных и генетических программ (Dobrenkov et al., 2008).

\section{Материалы и методы}

С 2009 по 2015 годы 11 сортов ежевики и малино-ежевичный гибрид (табл. 1), полученные из пробирочной коллекции ВИР (Санкт-Петербург) в стадии ризогенеза, изучали в полевых условиях филиала Майкопской опытной станции ВИР по признакам адаптивности и комплексу хозяйственно ценных признаков. Перед пересадкой микрорастений из пробирок в почвенные контейнеры для характеристики их развития у 5-6-ти микрорастений каждого образца были сделаны подсчеты и замеры основных биометрических показателей (число придаточных корней, средняя длина корней, высота растения, количество листьев).

Для адаптации микрорастений ежевики к более жестким условиям in vivo, пикировку укорененных пробирочных образцов проводили по одному растению непосредственно в контейнеры с почвой (по 200 г) и последующей акклиматизацией под пластмассовыми покрытиями (Broom, Zimmerman, 1978). Стерильный субстрат состоял из смеси: лесная почва : песок (3:1). Температура воздуха в лаборатории была $22-24^{\circ} \mathrm{C}$. Полив растений повторяли через 2-3 дня (Dobrenkov, 2002). В течение 4-х месяцев наблюдали за их развитием, отмечая процент живых растений у каждого образца. Затем отобрали по три хорошо развитых растения, считая каждое за повторность, и пересадили их из контейнеров на блоки $\left(1,5 \mathrm{~m}^{2}\right.$, расстояние между блоками 3 м) коллекционного участка. С 2009 года растения изучали в полевых условиях по комплексу показателей. Отмечали отрастание побегов после зимы, фазы развития растений, элементы урожайности, засухоустойчивость, восприимчивость ежевик к грибным патогенам. Методики изучения образцов использованы общепринятые (Guidelines for assessing..., 1968; Sinkova, 1980; Gruner, 1993; Program and methodology..., 1999).

В фазу массового созревания ягод оценивали оводненность, тургор и водоудерживающую способность листьев лабораторным методом (Semenova, Dobrenkov, 2001).

\section{Результаты и обсуждение}

Развитие микрорастений перед переносом из пробирочной культуры в контейнеры с грунтом практически у всех образцов 
оценивалось как относительно хорошее (см. ца после пересадки пробирочных растений табл. 1). Самыми низкими параметрами от- в контейнеры на почвенный субстрат покаличался сорт 'Bodega Bay'.

затели приживаемости колебались от 44,4

Результаты опыта, представленные в ('Merton Thornless') до 100\% ('Cascade', таблице 2, показывают, что через 3-4 меся- 'Whitford Thornless', 'Young').

Таблица 1. Биометрические показатели развития растений ежевики in vitro, 2008 г. Table 1. Biometric indicators of blackberry plant development in vitro, 2008

\begin{tabular}{l|c|c|c|c}
\hline \multicolumn{1}{c|}{$\begin{array}{c}\text { Образец, } \\
\text { интродукционный № ВИР }\end{array}$} & $\begin{array}{c}\text { Число прида- } \\
\text { точных кор- } \\
\text { ней, шт. }\end{array}$ & $\begin{array}{c}\text { Длина кор- } \\
\text { ней, см }\end{array}$ & $\begin{array}{c}\text { Высота рас- } \\
\text { тений, см }\end{array}$ & $\begin{array}{c}\text { Число ли- } \\
\text { стьев на } \\
\text { растении, } \\
\text { шт. }\end{array}$ \\
\hline Ashton Cross, И-581145 & $3-9$ & $1-3$ & $14,5 \pm 0,5$ & $21,9 \pm 0,8$ \\
\hline Bodega Bay, И-576483 & $1-2$ & $1-2$ & $3,70,4$ & $6,1 \pm 0,3$ \\
\hline Cascade, И-576485 & $3-12$ & $1-6$ & $4,3 \pm 0,6$ & $7,3 \pm 0,4$ \\
\hline Dirksen Thornless, И-581140 & $2-3$ & $1-6$ & $9.8 \pm 0,4$ & $16,0 \pm 0,8$ \\
\hline Eldorado, И-588470 & $2-7$ & $1-5$ & $7,2 \pm 1,0$ & $8,2 \pm 0,4$ \\
\hline Evergreen Thornless, И-576490 & $1-3$ & $1-6$ & $8,2 \pm 0,5$ & $11,5 \pm 0,5$ \\
\hline Logan Thornless, И-576496 & $1-2$ & $3-10$ & $11,8 \pm 0,9$ & $7,0 \pm 0,8$ \\
\hline Merton Thornless, И-581143 & $2-5$ & $1-2$ & $3,7 \pm 0,2$ & $6,7 \pm 0,5$ \\
\hline Santiam, И-576508 & $2-3$ & $1-2$ & $4,50,2$ & $8,4 \pm 0,5$ \\
\hline $\begin{array}{l}\text { Tayberry (малино-ежевичный } \\
\text { бpид), И-144669 }\end{array}$ & $3-4$ & $1-4$ & $5,70,3$ & $7,2 \pm 0,5$ \\
\hline Whitford Thornless, И-576516 & $1-4$ & $1-4$ & $3,3 \pm 0,3$ & $11,2 \pm 0,4$ \\
\hline Young, И-576517 & $3-6$ & $1-7$ & $5,4 \pm 0,4$ & $7,8 \pm 0,3$ \\
\hline
\end{tabular}

Таблица 2. Жизнеспособность образцов ежевики в почвенном субстрате, 2009 г. Table 2. Viability of blackberry accessions in soil substrate, 2009

\begin{tabular}{l|c|c|c}
\hline \multicolumn{1}{c|}{ Образец } & $\begin{array}{c}\text { \% живых растений после пересадки из про- } \\
\text { бирок в контейнеры }\end{array}$ & $\begin{array}{c}\text { Общее состояние } \\
\text { растений перед } \\
\text { переносом в поле- } \\
\text { вые условия, балл }\end{array}$ \\
\cline { 2 - 4 } & \multicolumn{2}{|c}{} & \\
\cline { 2 - 4 } & \multicolumn{2}{|c}{ через 4 месяца 1 месяц } & 5,0 \\
\hline Ashton Cross & 82,8 & 63,3 & 4,0 \\
\hline Bodega Bay & 71,0 & 100,0 & 5,0 \\
\hline Cascade & 100,0 & 75,0 & 5,0 \\
\hline Dirksen Thornless & 100,0 & 72,7 & 5,0 \\
\hline Eldorado & 91,0 & 66,7 & 4,5 \\
\hline Evergreen Thornless & 100,0 & 75,0 & 5,0 \\
\hline Logan Thornless & 75,0 & 44,4 & 5,0 \\
\hline Merton Thornless & 100,0 & 73,1 & 4,5 \\
\hline Santiam & 100,0 & 83.1 & 4,5 \\
\hline Tayberry & 100,0 & 100,0 & 5,0 \\
\hline Whitford Thornless & 100,0 & 100,0 & 5,0 \\
\hline Young & 100,0 & & 5,0 \\
\hline
\end{tabular}

Визуальная оценка состояния растений контейнеров на делянки. В опыте осталось перед переносом образцов в полевые усло- 11 образцов. За 7 лет наблюдений средний вия была высокой (4,5-5,0 баллов). На 4,0 балл состояния ежевик после перезимовок балла оценивался только сорт 'Bodega Bay'. (конец марта) колебался от 3,0 до 4,5 (табл.

С момента пересадки образцов в есте- 3). Погодные условия зимних периодов в ственные условия среды почти все сорта и основном соответствовали средним многогибрид развивались нормально. Очень сла- летним значениям. Экстремальными следубыми оказались только растения 'Bodega ет считать январь-февраль 2012 года, деВау’, засохшие сразу после их переноса из кабрь 2013, январь и февраль 2014 года, 
когда отмечались резкие перепады температуры воздуха (от -21 до $+20^{\circ} \mathrm{C}$ ). Кроме того, с декабря 2013 по февраль 2014 года, бину при отсутствии снежного покрова, темпера- тура на поверхности почвы трижды снижалась до $-24^{\circ} \mathrm{C}$, а почва промерзала на глудо $30 \mathrm{~cm}$.

Таблица 3. Оценка устойчивости образцов ежевики к абиотическим факторам среды, 2009-2015 гг.

Table 3. Assessment of the resistance of blackberry accessions to abiotic environmental factors, 2009-2015

\begin{tabular}{l|r}
\hline \multicolumn{1}{c|}{ Образец } & после пер \\
\cline { 2 - 2 } & \\
\hline Ashton Cross & 3,0 \\
\hline Cascade & 3,0 \\
\hline Dirksen Thornless & 4, \\
\hline Eldorado & 4,5 \\
\hline Evergreen Thornless & 4, \\
\hline Logan Thornless & 4, \\
\hline Merton Thornless & 4,0 \\
\hline Santiam Blackberry & 4, \\
\hline Tayberry & 4,0 \\
\hline Whitford Thornless & 4,5 \\
\hline Young & 4,5 \\
\hline
\end{tabular}

Состояние растений, балл

В этот экстремальный для ежевик год приятные годы хорошо плодоносят

(2014) у образцов 'Whitford Thornless', 'Cascade', 'Young', 'Santiam', 'Logan 'Dirksen Thornless', 'Eldorado', 'Logan Thornless', 'Tayberry'. Сорт 'Whitford Thornless', 'Young' подмерзла только верх- Thornless' образует много недоразвитых няя часть прошлогодних побегов. Для сор- ягод.

тов 'Evergreen Thornless', 'Merton Thornless', 'Santiam' и гибрида 'Tayberry' было характерно подсыхание 3/4 побегов, а у сортов 'Ashton Cross', 'Cascade' побеги вымерзли практически до уровня почвы. В конце апреля - начале мая у ежевик началось интенсивное образование побегов замещения, что позволило получить относительно хороший урожай. Из изученных образцов слабее других отрастали побеги у 'Santiam', а урожай не превышал 1,0 балла.

Семилетние наблюдения показали, что массовое плодоношение образцов 'Cascade', 'Logan Thornless', 'Santiam', 'Tayberry', 'Whitford Thornless', 'Young' приходится на вторую декаду июня. Фаза массового созревания сортов 'Dirksen Thornless', 'Eldorado' начинается в третьей декаде июня, у 'Ashton Cross' - в первой декаде июля, а у 'Merton Thornless' - с середины августа.

Стабильно высокоурожайными (4,5-5,0 баллов) являются образцы 'Dirksen Thornless', 'Eldorado', 'Evergreen Thornless'; среднеурожайными $\quad(3,0-4,0$ балла) 'Merton Thornless', 'Ashton Cross'. В зависимости от условий перезимовки в благо-

Крупноплодностью (до 7,5 г) и товарностью ягод выделяются сорта 'Dirksen Thornless', 'Eldorado', 'Young'.

Следует заметить, что у сорта 'Whitford Thornless' образуются единичные побеги с мягкими зелеными шипами. Расхимеривание от корня наблюдается у растений сорта 'Evergreen Thornless' - появляются плодоносящие и растущие побеги с жесткими шипами, как у родительской формы Rubus laciniatus Willd., представленной в полевой коллекции станции с 1977 года.

Для предгорной зоны Республики Адыгея в летний период характерно воздействие на растения высоких температур воздуха. С 2009 года абсолютный максимум колебался в июле от $34^{\circ} \mathrm{C}$ до $36^{\circ} \mathrm{C}$, а в августе от $30^{\circ} \mathrm{C}$ до $38^{\circ} \mathrm{C}$ (2014 г.). Кроме того, практически отсутствовали осадки в августе 2010 г. (ГТК 0,3 при норме 1,2); в июле - августе 2011 г. (ГТК 0,9; 0,4); в августе 2014 г. (ГТК 0,1).

В полевых условиях после длительного воздействия на растения засухи и жары общее состояние ежевик визуально оценивалось на 4,5-5,0 баллов. Отмечено пожелтение и раннее подсыхание нижних листьев 
(температура на поверхности почвы в отдельные дни достигала $63^{\circ} \mathrm{C}$ ). Внешне больше других страдал сорт 'Ashton Cross': листья скручивались вверх, становились очень хрупкими, а нижние - засыхали.

Установлено, что у более засухоустойчивых растений ежевики оводненность, тургор и водоудерживающая способность листьев в засуху или при искусственном увядании выше, чем у неустойчивых, а амплитуда колебаний показателей водного режима у первых ниже (Semenova, Dobrenkov, 2001). У ex vitro образцов в фазу созревания ягод листья в средней части побегов к 9 часам утра были оводнены на 56-66\%. За 6 часов обезвоживания в лабораторных условиях при температуре $40^{\circ} \mathrm{C}$ листья теряли до $53 \%$ воды, что говорит о довольно высокой их водоудерживающей способности. В этом плане относительно засухо- и жароустойчивым оказался сорт 'Logan Thornless': потери воды составляли всего 27\%. Хорошие показатели имели сорта 'Cascade', 'Eldorado', 'Evergreen Thornless', 'Merton Thornless', 'Whitford Thornless' и 'Young', листья которых при обезвоживании в аналогичных условиях теряли до $40 \%$ воды. Более 50\% воды теряли листья сорта 'Ashton Cross', что характеризует его как неустойчивый к засухе и жаре.

Оценка восприимчивости ежевик к грибным патогенам показала, что мучнистой росой повреждались только сорта 'Young' и 'Cascade' (2-3 балла) в 2009, 2011, 20014 и 2015 годах.

Относительно высокую полевую устойчивость к пятнистостям листьев (поражение антракнозом и септориозом до 1,0 балла) за все годы наблюдений проявляли 'Evergreen Thornless', 'Whitford Thornless' (табл. 4).

Таблица 4. Степень устойчивости образцов ежевики к пятнистостям, 2009-2015 rr.

Table 4. The degree of resistance of blackberry accessions to spots, 2009-2015

\begin{tabular}{l|l}
\hline \multicolumn{1}{c|}{ Степень полевой устойчивости* } & \multicolumn{1}{c}{ Образец } \\
\hline $\begin{array}{l}\text { Практическая устойчивость } \\
\text { (до } 1,0 \text { балла) }\end{array}$ & Evergreen Thornless, Whitforg Thornless. \\
\hline $\begin{array}{l}\text { Слабая восприимчивость } \\
(1-2 \text { балла) }\end{array}$ & $\begin{array}{l}\text { Ashton Cross, Eldorado, Logan Thornless, } \\
\text { Merton Thornless. }\end{array}$ \\
\hline $\begin{array}{l}\text { Средняя восприимчивость } \\
(2-3 \text { балла) }\end{array}$ & Dirksen Thornless, Young. \\
\hline $\begin{array}{l}\text { Высокая восприимчивость } \\
(3,5 \text { балла) }\end{array}$ & Cascade, Santiam, Tayberry. \\
\hline
\end{tabular}

*образцов с отсутствием признаков поражения листьев не выявлено

В эпифитотийные годы (2009, 2011 гг.) высоко восприимчивыми оказались 'Cascade', 'Santiam', 'Tayberry' (3,5-4,0 балла).

\section{Заключение}

После длительного хранения образцов ежевики в пробирочной культуре приживаемость большинства укорененных in vitro растений в контейнерах со стерильной почвой относительно высокая (75-100\%).

Пересаженные растения из контейнеров в естественные условия довольно легко адаптируются, хорошо растут и развиваются. Это позволяет выявлять ценные признаки сортов и оценивать степень их адаптивности к стрессорам предгорной зоны Республики Адыгея.

\section{References/Литература}

Gruner L. A. Classifier of the genus Rubus L., subgenus Eubatus Focke (blackberry) (Klassifikator roda Rubus L., podroda Eubatus Focke (ezhevika). SPb.: VIR, 1993, 20 p. [in Russian] (Грюнер Л. А. Классификатор рода Rubus L., подрода Eubatus Focke (ежевика). СПб.: ВИР, 1993. 20 с.).
Dobrenkov E. A. Adaptive potential of blackberry in the climatic conditions of the Western foothills of the North Caucasus (Adaptivnyj potencial ezheviki v klimaticheskih uslovijx Zapadnogo predgor'ja Severnogo Kavkaza) // Diss. kand. ... s.-kh. Nauk - diss. cand. with.-of agricultural Sciences. St. Petersburg, 2002, pp. 93- 
107 [in Russian]. (Добренков E. А. Адаптивный потенциал ежевики в климатических условиях Западного предгорья Северного Кавказа // Дисс. ... канд. с.-х. наук. СПб., 2002. C. 93-107).

Dobrenkov E. A., Semenova L. G. et all. Raspberries and blackberries (the Response of plants to adverse environmental factors, chemical composition of fruits in conditions of a foothill zone of Republic Adygea): Catalogue of VIR world collection. (Malina i ezhevika (Reakcija rastenij na neblagoprijatnye faktory sredy, himicheskij sostav plodov $\mathrm{v}$ uslovijax predgornoy zony Respubliki Adygeja: Katalog mirovoj kollekcii VIR). St. Petersburg: VIR, 2008, vol. 790, 19 p. [in Russian] (Добренков Е. А., Семенова Л. Г. и др. Малина и ежевика (Реакция растений на неблагоприятные факторы среды, химический состав плодов в условиях предгорной зоны Республики Адыгея): Каталог мировой коллекции ВИР. СПб: ВИР, 2008. Вып. 790. 19 c.).

Dunaeva S. E., Gavrilenko T. A. Collections of fruit and berry cultures in vitro: a strategy for the creation and storage // Proceedings on applied botani, genetics and breeding, 2007, vol. 161, pp. 10-19 [in Russian] (Дунаева С. Е., Гавриленко T. A. Коллекции плодовых и ягодных культур in vitro: стратегия создания и хранение // Тр. по прикл. бот., ген. и сел. 2007. Т. 161. C. 10-19).

Dunaeva S. E., Pendinen G. I. et. all. Conservation of vegetative propagated crops in vitro and kriocollections. Methodical instructions (Soxranenie vegetativno razmnozhaemyx kul'tur $\mathrm{v}$ in vitro i kriokollekciyax. Metodicheskie ukazaniya). SPb.: VIR, 2011, 64 p. [in Russian] (Дунаева С. Е., Пендинен Г. И. и др. Сохранение вегетативно размножаемых культур в in vitro и криоколлекциях. Методические указания. СПб.: ВИР, 2011.64 с.).

Guidelines for assessing the comparative sustainability of fruit and berry crops to major diseases /Ed. by Minkevich I. I. (Metodicheskie ukazanija po ocenke sravnitel'noj ustojchivosti plodovo-jagodnyx kul'tur $\mathrm{k}$ osnovnym zabolevanijam). Leningrad: VIR, 1968, 67 p. [in Russian] (Методические указания по оценке сравнительной устойчивости плодово-ягодных культур к основным заболеваниям / под ред. И. И. Минкевич Л.: ВИР, 1968. 67 с.).

Program and methodology of variety investigation of fruit, berry and nut crops /Ed. Sedov E. N., Ogol'tsova T. P. (Programma i metodika sortoizucheniya plodovykh, yagodnykh i orehoplodnykh kul'tur). Orel: VNIISPK, 1999, 608 p. [in Russian] (Программа и методика сортоизучения плодовых, ягодных и орехоплодных культур / под ред. Седова Е. Н., Огольцовой Т. П. Орел: ВНИИСПК, 1999. 608 с.).

Semenova L. G., Dobrenkov E. A. Adaptation potential of blackberry in the Western foothills of the North Caucasus (Adaptacionnyj potencial ezheviki v usloviyax Zapadnogo predgor'ya Severnogo Kavkaza). Majkop, 2001, 83 p. [in Russian] (Семенова Л. Г., Добренков Е. А. Адаптационный потенциал ежевики в условиях Западного предгорья Северного Кавказа. Майкоп, 2001. 83 с.).

Sinkova M. G. Classifier of the genus Rubus L. (raspberry, blackberry). (Klassifikator roda Rubus L. (malina, ezhevika). Leningrad: VIR, 1980, 17 p. [in Russian] (Синькова Г. М. Классификатор рода Rubus L. (малина, ежевика). Л.: ВИР, 1980. 17 с.).

Broom O. C., Zimmerman R. H. In vitro propagation of blackberry // Hort. Science, 1978, vol. 13, pp. 151-153. 


\section{КОА ЕКЦИИ МИРОВЫХ ГЕНЕТИЧЕСКИХ РЕСУРСОВ КУАЬТУРНЫХ РАСТЕНИЙ АИЯ РАЗВИТИЯ ПРИОРИТЕТНЫХ НАПРАВАЕНИЙ СЕАЕКЦИИ}

DOI: $10.30901 / 2227-8834-2017-1-31-40$

УДК 633.14:631.527:581.19

ОРИГИНАЛЬНАЯ СТАТЬЯ

\section{В. Д. Кобылянский ${ }^{1}$, О. В. Солодухина ${ }^{1}$, И. В. Лунегова ${ }^{2}$, С. П. Новикова ${ }^{3}$, М. С. Хлопюк ${ }^{4}$, В. И. Макаров ${ }^{4}$}

${ }^{1}$ Федеральный исследовательский центр Всероссийский институт генетических ресурсов растений имени Н. И. Вавилова, 190000 Санкт-Петербург, ул. Б. Морская д. 42,44 , Россия, e-mail: osolodukhina@yandex.ru

${ }^{2}$ Санкт-Петербургская государственная академия ветеринарной медицины, 196084, Россия, Санкт-Петербург, ул. Черниговская, д.5, e-mail: ivlunegova@yandex.ru

${ }^{3}$ «Озерский свинокомплекс» 301484, Россия, Тульская обл., Плавский район, дер. Кобылинский хутор

${ }^{4}$ Тульский научноисследовательский институт сельского хозяйства, 301493, Россия, Тульская обл., Плавский район, пос. Молочные дворы, ул. Садовая, д.7, e-mail: svetlana_khoreva@mail.ru, e-mail: tniisx@mail.ru

\section{Ключевые слова:} зернофуражная рожь, генетика, технология селекиии, сорт, рационы, крысы, свиньи, иььплята

Поступление: 21.12.2016

Принято: 06.03.2017

\section{СОЗДАНИЕ НИЗКОПЕНТОЗАНОВОЙ РЖИ И ВОЗМОЖНОСТИ ЕЕ ИСПОЛЬЗОВАНИЯ НА КОРМ животным}

Использование зерна ржи на корм животным ограничено наличием в нем большого количества водорастворимых пентозанов (арабинозы и ксилозы). В зерне ржи их содержится в три раза больше, чем в других зерновых культурах. Водорастворимые арабиноксиланы (ВАК) зерна в желудке животных образуют слизи, которые ограничивают доступ пищеварительных ферментов к питательным веществам зерна. Они не гидролизуются ферментами животных и не сбраживаются дрожжами, что позволяет им в виде слизей пройти через весь пищеварительный тракт, сохраняя свою вредоносность. Во Всероссийском институте генетических ресурсов растений имени Н. И. Вавилова (ВИР) проведены исследования 480 образцов коллекции озимой ржи из мирового генофонда ВИР по развитию нового направления в селекции зернофуражной ржи - «Создание ржи с низким содержанием водорастворимых пентозанов в зерне». В результате поиска исходного материала для селекции среди 480 образцов коллекции озимой ржи из мирового генофонда не обнаружено готовых низкопентозановых сортов, пригодных для прямого зернофуражного использования. Однако установлено, что разные популяции ржи в своем составе содержат низкопентозановые формы растений с частотой $0,1-20,0 \%$. Выявлены шесть популяций ржи, включающих около $20 \%$ генотипов с низким содержанием $(0,5-0,7 \%)$ водорастворимых пентозанов в зерне. Определен рецессивный полигенный характер наследования признака низкого содержания ВАК в зерне. Выявлено уменьшение толщины перикарпия на 40-60\% у низкопентозановых зерновок по сравнению с высокопентозановыми. Эта причинно-следственная связь позволила нам сформулировать стратегию и технологию селекции и семеноводства низкопентозановой ржи. Совместно с сотрудниками других селекционных учреждений созданы шесть сортов зернофуражной озимой ржи, не имеющей мировых аналогов. Новая рожь характеризуется низким, как у пшеницы, содержанием водорастворимых фракций пентозанов. Низкое содержание ВАК в зерне устраняет возможность образования слизей в желудке животных, чем снимает проблему, возникающую при кормлении классической хлебопекарной рожью. При использовании низкопентозанового зерна в качестве корма лабораторными и сельскохозяйственными животными наблюдали его предпочтительную поедаемость и высокую питательную ценность. Для получения прироста массы животных при использовании единицы корма, зерно этой ржи превосходит все зерновые культуры. Использование зерна низкопентозановой ржи для фуражных целей в рационах поросят способствует снижению конверсии корма до $42 \%$ по сравнению с патентованными комбикормами. Получены результаты, свидетельствующие о возможности успешного использования зерна низкопентозановой ржи при кормлении птицы. 


\section{COLLECTIONS OF THE WORLD'S CROP GENETIC RESOURCES FOR THE DEVELOPMENT OF PRIORITY PLANT BREEDING TRENDS}

V. D. Kobyliansky ${ }^{1}$, O. V. Solodukhina ${ }^{1}$, I. V. Lunegova ${ }^{2}$, S. P. Novikova ${ }^{3}$, M. S. Hlopyuk ${ }^{4}$, V. I. Makarov ${ }^{4}$

${ }^{1}$ The N. I. Vavilov All-Russian Institute of Plant Genetic Resources, 42, 44, Bolshaya Morskaya str., St. Petersburg, 190000 Russia e-mail: osolodukhina@yandex.ru

${ }^{2}$ St. Petersburg State Academy of Veterinary Medicine,

5, Chernigovskaya St.,

St. Petersburg, 196084, Russia, e-mail: ivlunegova@yandex.ru

${ }^{3}$ Ozersk Pig Farm, Kobylynsky Farmstead, Plavsky District, Tula Province, 301484, Russia

e -mail: svetlana_khoreva@mail.ru

${ }^{4}$ Tula Agricultural Research Institute, 7, Sadovaya St., Molochnye Dvory Settlement, Plavsky District, Tula Province, 301493, Russia,

e-mail: tniisx@mail.ru

Key words:

grain forage rye, genetics, technology of breeding, variety, diets, rats, pigs, chicken

Received:

21.12.2016

Accepted:

06.03.2017

\section{RYE BREEDING FOR LOW-PENTOSANS AND POSSIBILITY OF ITS USE IN ANIMAL FEEDING}

Traditional rye grain surpasses all cereals in nutritional and biological values. But the use of rye grain for animal feeding is restricted by the presence of large quantities of water-soluble pentosans (arabinose and xylose). The content of these substances in rye grain is three times higher than that in other cereals. Water-soluble arabinoxylans (WS-AX) in dry seed in animal stomachs form mucus restricting digestive enzymes to have access to grain nutrients. They are not hydrolyzed by animals' enzymes and are not fermented by yeasts, which allows them to go through the entire gastrointestinal tract as mucus retaining their harmfulness. Investigations in new areas of grain forage rye breeding have been conducted under the title "Development of rye with low content of water-soluble pentosans in seeds". Having sought for source material for breeding among 480 winter rye accessions from the VIR global collection, we have not identified 'ready' low-pentosan varieties suitable for grain forage use. However, different rye populations were found to contain low-pentosan plants with frequencies $0.1-20.0 \%$. Six rye populations were identified containing approximately $20 \%$ genotypes with low content $(0.5-0.7 \%)$ of WS-AX in grain. Decrease of the pericarp thickness up to $40-60 \%$ was found in lowpentosan seeds as compared with high-pentosan ones. This cause-effect relationship allowed us to formulate the strategy and technology of low-pentrosan rye breeding and seed production. The strategy and technology of rye breeding for low WS-AX content in grain should be carried out by reducing coating portions in seeds. Together with breeders from other institutions we developed six varieties of grain forage winter rye which are in the state trials now. Like wheat, such rye has low content of water-soluble pentosan fractions. Seeds of low-pentosan forage rye do not form viscous mucus in animal stomachs. When used as feed for laboratory and farming animals, the varieties demonstrated high palatability and nutritional value. The increase of body weight of rats by $12 \%$, if compared with barley, or $27 \%$, if compared with wheat, was observed. If production increase (animal weight) per fodder unit is to be achieved, such rye grain surpasses all cereal crops. Using low-pentosan rye seed to feed piglets can decrease fodder conversion up to $42 \%$ as compared with patented mixed fodders. The obtained results confirm the possibility to successfully use lowpentosan forage rye grain for feeding poultry. 
Современное производство концентрированных кормов для сельскохозяйственных животных осуществляется при использовании основных зерновых культур: пшеницы, тритикале, ячменя и кукурузы. Проблема использования зерна ржи в кормопроизводстве всегда привлекала внимание производителей. Рожь по питательной ценности белка превосходит другие зерновые культуры (за исключением овса). Белок зерна ржи на $83 \%$ соответствует молочному казеину коров, тогда как у пшеницы - лишь на $41 \%$. Белок ржи содержит 3-4\% лизина и более благоприятно сбалансирован по другим незаменимым аминокислотам (Kobylyansky, 1982).

Частичное решение этой проблемы в России достигнуто за счет различных технологий механической и тепловой обработки зерна, применения ферментных добавок в рационах, или при одновременном сочетании разных технологий. Вышеупомянутые способы улучшения кормовой ценности зерна хлебопекарной ржи все равно не обеспечивают должного уровня усвояемости корма животными. Высокозатратность производства сырья приводит к удорожанию комбикормов и продукции животноводства до $30 \%$. На практике в комбикормовой промышленности России использование зерна ржи без ферментативных и пищевых добавок не превышает 5\% валового сбора урожая (Ficev, Kosolapov, 2008).

Главным препятствием для употребления зерна современных сортов хлебопекарной ржи на корм животным, особенно с однокамерным желудком (свиньи, птицы), служат пятиуглеродные сахара (пентозаны) - водорастворимые арабиноза и ксилоза (ВАК), которые не сбраживаются дрожжами и не перевариваются ферментами животных и человека. Пентозаны содержатся в зерне всех злаковых культур. Но их количество у ржи в три раза больше, чем, например, у пшеницы.

Водорастворимые арабиноксиланы в полимерном состоянии характеризуются высокой гидрофильностью и способны поглощать воду в количестве, которое в 8-10 раз больше их массы. В результате этого образуются вязкие гели (слизи), которые затрудняют доступ пищеварительных ферментов к белкам, жирам и крахмалу зерна. Кроме того, слизи, покрывая слизью стенки кишечника, ограничивают всасывание и усвоение продуктов пищеварения (Cyran, Rakowska et. al., 1995; Boros, Lukaszewski,
Aniol, 2001; Boros, 2007). Арабиноксиланы не перевариваются ферментами человека и животных, не гидролизуются дрожжами, и проходят через весь пищеварительный путь без изменений. Другие полисахариды гидролизуются ферментами желудка и не создают проблем при пищеварении (Pleshkov, 1965).

Цель наших исследований - разработать технологию селекции низкопентозановой зернофуражной озимой ржи и создать популяционные сорта, пригодные для использования в комбикормовой промышленности.

Почти все водорастворимые пентозаны локализованы в периферийной части зерновки и находятся в полимерном молекулярном состоянии. Арабиноксиланы (арабиноза и ксилоза) входят в состав гемицеллюлозы и, наряду с другими моносахарами, целлюлозой, лигнином и минеральными веществами, служат структурными компонентами клеточных стенок (Dimenshtein, Ermakov et al., 1958). Основным местом концентрации арабиноксиланов служат те ткани зерновок, которые состоят из большого числа толстостенных клеток. Наиболее толстыми стенками характеризуются клетки оболочки зерновки и алейронового слоя.

Водорастворимые пентозаны по своим функциям можно разделить на два класса: пассивные и активные. Пассивные расположенные в клеточных стенках и межклеточном пространстве плодовой и семенной оболочек. Плодовая оболочка исполняет функцию защиты плода и семени от неблагоприятных условий внешней среды. Ее пентозаны поглощают влагу и передают ее семенной оболочке. На этом этапе биологическая функция пентозанов из плодовой оболочки заканчивается.

Активные пентозаны находятся в стенках клеток алейронового слоя. При набухании зерна вода диффузно через семенную оболочку поступает к клеткам зародыша и алейронового слоя. В результате этого происходит, с одной стороны, прорастание зародыша, с другой - активизируется процесс обмена веществ в клетках алейронового слоя. В этот период активные пентозаны алейронового слоя зерна под действием собственных ферментов, переходят из полимерного состояния молекул в активное мономерное состояние - пентозы. При прорастании зерна пентозы принимают участие в обмене веществ и служат первичным 
строительным материалом для клеточных стенок формирующихся тканей зародыша.

В процессе приготовления кормов из зерна классической ржи происходит объединение пассивных и активных водорастворимых пентозанов. Это способствует возникновению антипитательных свойств корма при смачивании его в желудке, чем создает проблему при использовании в кормлении животных.

Для выявления форм ржи с малым содержанием ВАК в зерне во Всероссийском институте генетических ресурсов растений имени Н. И. Вавилова (ВИР) провели изучение 480 образцов озимой и яровой ржи из коллекции ВИР, представленных отечественными и зарубежными сортами и формами различного географического происхождения. Мы не обнаружили готовых источников малого содержания ВАК (0,5$1,0 \%)$ в зерне. Выявлена большая внутрипопуляционная изменчивость признака. Низкопентозановые формы отмечали в пределах разных популяций ржи с частотой 0,1-20,0\%.

Анатомо-морфологическое изучение зерновок ржи с низким содержанием ВАК показало уменьшение толщины перикарпия на 40-60\% по сравнению с таковым у высокопентозановых зерновок. Согласно исследованиям, Е. Д. Казакова (Kazakov, 1947) и Л. Н. Любарского (Lyubarskii, 1956), средние показатели доли оболочки в составе зерна ржи варьируют от 7,4 до 12,4 \% при толщине 60,1-101,4 мкм. Зерно пшеницы содержит в три раза меньше ВАК, чем у ржи, и характеризуется в три раза меньшей толщиной оболочки.

Выявленный нами большой размах вариаций биотипов в популяциях ржи по доле оболочек от массы зерновки позволяет распознавать и отбирать формы растений с «тонкопокровным» зерном. Мы обнаружили, что чем тоньше оболочка зерна, тем меньше в нем водорастворимых арабиноксиланов. В результате этот показатель был положен в основу идентификации низкопентозановых зерновок ржи (Kobylyansky, Solodukhina, 2009).

При изучении наследования признака содержания ВАК в зерне обнаружили четкое доминирование или сверхдоминирование высокого содержания ВАК над низким y всех гибридов в $\mathrm{F}_{1}$ и рецессивный характер наследования низкого содержания ВАК (Kobylyansky, Solodukhina, 2010; 2013).

Анализ структуры популяции сорта
‘Эра' по числу генотипов с неодинаковым содержанием ВАК в зерне выявил их «нормальное» распределение (рис. 1).

Это характерно для полигенно контролируемых признаков. Генотипы с крайне низкими показателями ВАК можно использовать для целей селекции. Известно, что содержание пентозанов в зерне ржи контролируют гены, размещенные во всех хромосомах (Boros, Lukaszewski, Aniol, 2001). Это позволяет предположить, что признак обусловливают не менее чем семь генов и большое число аллелей каждого локуса. Проявление признака возможно только при благоприятном сочетании аллелей каждого локуса всех хромосом генома.

Результаты реципрокных скрещиваний альтернативных по содержанию ВАК форм ржи свидетельствуют об отсутствии влияния отцовских компонентов скрещивания на качество гибридных семян материнских растений (Kobylyansky, Solodukhina, 2010). Фенотипическое проявление низкопентозановости выражается в сохранении у гибридных семян признака низкого содержания ВАК материнского фенотипа. Это можно объяснить тем, что оболочки гибридного зерна состоят из материнских тканей и не являются гибридными и поэтому не меняют своей структуры (Schmalz, 1969). Это означает, что в товарных посевах, в случае опыления растений низкопентозановых сортов пыльцой растений с высоким содержанием ВАК, полученное гибридное зерно останется низкопентозановым. Но в потомствах $\mathrm{F}_{2}$ и последующих поколениях, выращенных из этих семян, будет наблюдаться расщепление по содержанию ВАК и потеря низкопентозановости. Из этого следует, что для обеспечения генетической чистоты селекционных низкопентозановых материалов, посевы первичного семеноводства, элиты и товарного семеноводства необходимо размещать в местах, исключающих возможность их переопыления чужеродной пыльцой.

Популяции ржи, изученные в течение пяти лет по содержанию ВАК в зерне, показали различную реакцию на условия года. У одних популяций эта реакция была сильной $(C v=10,3-14,1 \%)$, у других - слабой $(C v=2,7-3,9 \%)$, что указывает на возможность создания сортов ржи, стабильно сохраняющих признак низкого содержания BAК в течение многих лет (Kobylyansky, Solodukhina, 2013). 


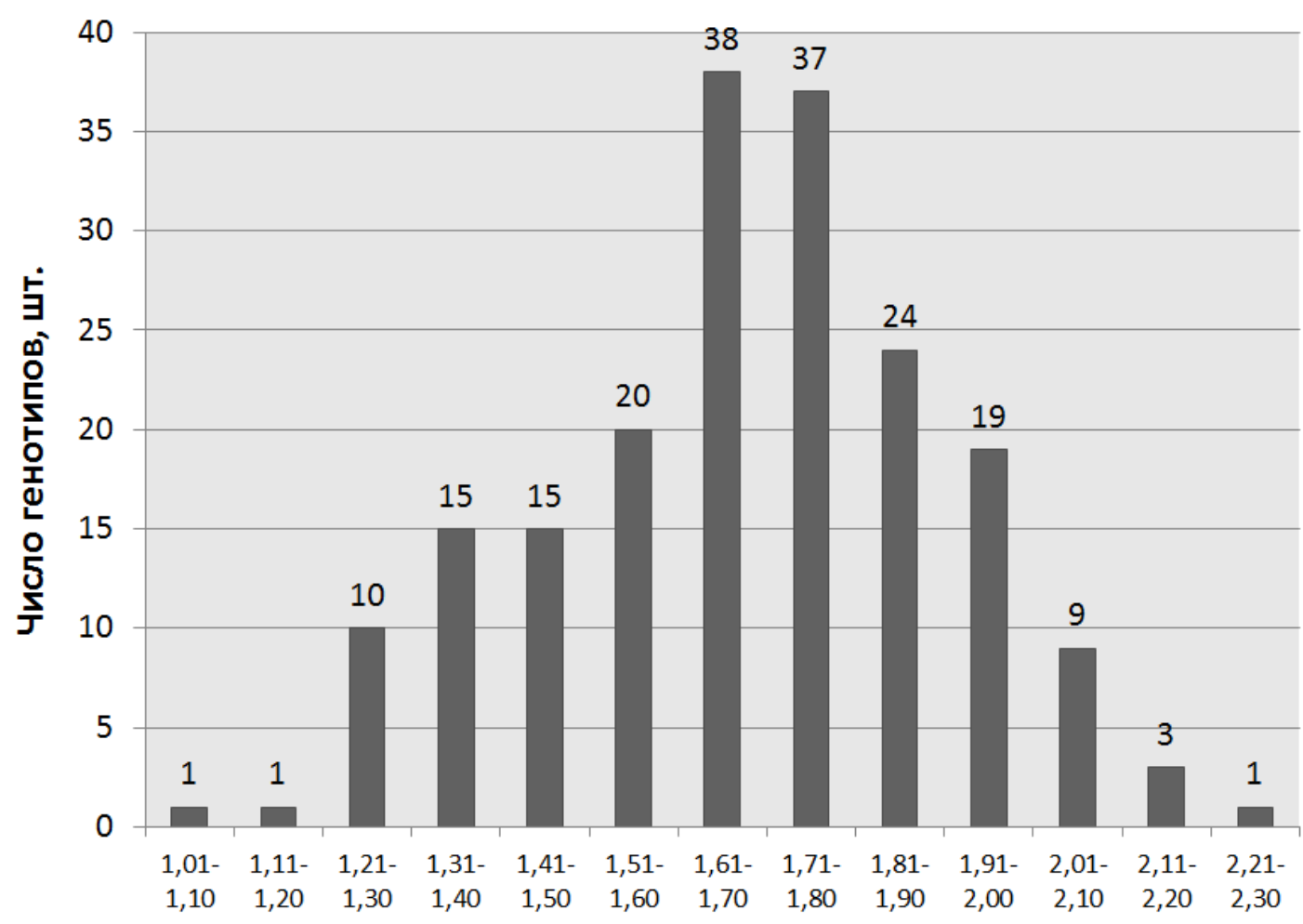

Содержание ВАК в зерне, \% на сухое вещество

\section{Рис. 1. Распределение генотипов по содержанию водорастворимых арабиноксиланов в зерне в популяции ржи сорта Эра}

Fig. 1. Distribution of genotypes in the rye variety Era population according to the content of water-soluble arabinoxilans (WS-AX) in grain

В настоящее время информации о генетике признака низкого содержания ВАК в зерне ржи очень мало, но ее вполне достаточно для создания зернофуражной ржи (Kobylyansky, Solodukhina, 2013). Изучение наследования и изменчивости признака низкопентозановости зерна позволило разработать технологию селекции зернофуражной ржи с низким содержанием ВАК в зерне и создать исходный материал, с комплексом других селекционно-ценных признаков.

По внешнему виду низкопентозановые зерна имеют тонкие покровы и заметно отличаются от высокопентозановых с толстыми покровами. Оболочки тонкопокровных зерен более гладкие, прозрачные и в определенных условиях освещения выглядят стекловидными. В связи с этим можно проводить визуальный отбор низкопентозановых зерновок, не прибегая к биохимической оценке (know haw). Стратегия и технология селекции ржи с низким содержанием водорастворимых арабиноксиланов в зерне должна осуществляться путем уменьшения доли оболочек в составе зерновок.

Кроме биохимического, мы предложили несколько вариантов технологий, позволяющих идентифицировать растения популяций озимой ржи по содержанию ВАК в зерне для целей селекции:

Метод клоновых половинок. При использовании этого метода из каждого тонкопокровного зерна изучаемой сортовой популяции или гибрида в первый год в период весна - осень получают до 25-30 клонов одного генотипа. После яровизации растений часть колосьев каждого клонированного генотипа изолируют до цветения для получения самоопыленных потомств. Завязавшееся зерно визуально отбирают по тонкопокровности с целью выявления генотипов с низким содержанием ВАК. Метод клоновых половинок позволил идентифицировать в пределах популяций разных сортов более 90 источников малого содержания ВАК в зерне, которые были использованы в селекции зернофуражных сортов ржи. 
Таблица 1. Сорта озимой низкопентозановой зернофуражной ржи, прошедшие Государственное сортоиспытание (2012-2016 гг.)

Table 1. Low-pentosan winter forage rye cultivars which passed the State Variery Trials in 2012-2016

\begin{tabular}{|c|c|c|c|c|c|c|}
\hline \multirow[b]{2}{*}{$\begin{array}{c}\text { Сорта } \\
\text { Variety }\end{array}$} & \multirow[b]{2}{*}{$\begin{array}{c}\text { Авторы сорта } \\
\text { Authors of the } \\
\text { variety }\end{array}$} & \multirow{2}{*}{$\begin{array}{c}\text { № реги- } \\
\text { стра } \\
\text { ции } \\
\text { Registra- } \\
\text { tion } \\
\text { number }\end{array}$} & \multicolumn{2}{|c|}{$\begin{array}{c}\text { Физические показа- } \\
\text { тели зерна* } \\
\text { Physical characteris- } \\
\text { tics of grain }\end{array}$} & \multicolumn{2}{|c|}{$\begin{array}{c}\text { Содержание в } \\
\text { зерне, \% на сухое } \\
\text { вещество* } \\
\text { Content in grain, \% } \\
\text { per dried matter }\end{array}$} \\
\hline & & & $\begin{array}{c}\text { масca } \\
1000 \text { зе- } \\
\text { peн, г } \\
1000 \\
\text { grain } \\
\text { weight, g }\end{array}$ & $\begin{array}{c}\text { натура } \\
\text { зерна, } \\
\text { г/л } \\
\text { grain- } \\
\text { unit, g/l }\end{array}$ & $\begin{array}{c}\text { водорас- } \\
\text { творимые } \\
\text { пентозаны } \\
\text { water- } \\
\text { soluble } \\
\text { pentosans }\end{array}$ & $\begin{array}{c}\text { белок } \\
\text { pro- } \\
\text { tein }\end{array}$ \\
\hline Новая Эра & $\begin{array}{l}\text { ВИР, Псков- } \\
\text { ский НИИСХ }\end{array}$ & 8653808 & 37,1 & 705 & 0,64 & 8,8 \\
\hline Янтарная & $\begin{array}{l}\text { ВИР, Ураль- } \\
\text { ский НИИСХ }\end{array}$ & 8654640 & 39,6 & 749 & 0,53 & 9,0 \\
\hline Подарок & $\begin{array}{l}\text { ВИР, Татар- } \\
\text { ский НИИСХ }\end{array}$ & 8653091 & 36,0 & 782 & 0,68 & 8,6 \\
\hline Берегиня & $\begin{array}{l}\text { ВИР, ФГУП } \\
\text { «Котласское» }\end{array}$ & 8757428 & 35,0 & 742 & 0,50 & 9,1 \\
\hline Вавиловская & $\begin{array}{l}\text { ВИР, Тульский } \\
\text { НИИСХ }\end{array}$ & 8757855 & 35,1 & 757 & 0,42 & 9,9 \\
\hline $\begin{array}{l}\text { Красноярская } \\
\text { универсальная }\end{array}$ & $\begin{array}{l}\text { ВИР, Красно- } \\
\text { ярский } \\
\text { НИИСХ }\end{array}$ & 8559150 & 32,0 & 748 & 0,31 & 13,2 \\
\hline
\end{tabular}

*характеристика признаков зерна получена при выращивании ржи в Ленинградской обл. России * grain characteristics were studied when the rye was grown in Leningrad Province, Russia

Метод внутрипопуляционных накопительных скрещиваний предложен при использовании исходного материала с низкой частотой низкопентозановых генотипов. Это могут быть зерна, обнаруженные среди семян сортов традиционной ржи или потомства гибридов от скрещивания с донорами низкого содержания ВАК в зерне. Метод предполагает последовательный массовый отбор тонкопокровных зерновок и выращивание полученных из них растений в изолированных условиях для последующего внутрипопуляционного накопительного скрещивания. В каждом последующем поколении (G-генерации) повторяют отбор форм и их внутрипопуляционное скрещивание. В потомствах G7, в зависимости от качества отбора, частота тонкопокровных гомогенных зерновок достигает $20 \%$ и более.

Метод попарных переопылений может быть использован для отбора растений, гомогенных по признаку низкого содержания
ВАК в зерне. Для чего из урожая последней генерации G7-G8 накопительного внутрипопуляционного скрещивания выращивают растения, которые до цветения изолируют попарно для взаимного переопыления. После созревания зерно каждой пары оценивают визуально. Отбирают те пары, у которых оба растения имеют тонкопокровное зерно (know haw).

На основе материалов, полученных перечисленными методами, завершено создание серии доноров и 6 сортов озимой ржи с низким $(0,31-0,68 \%)$ содержанием ВАК в зерне. Первые шесть сортов, созданные совместно с селекцентрами других научных учреждений прошли Государственное сортоиспытание (табл. 1). Созданные в ВИР доноры низкого содержания водорастворимых пентозанов и лучшие популяции переданы в 15 научно-исследовательских учреждений РФ для развития перспективного направления селекции ржи (рис. 2). 


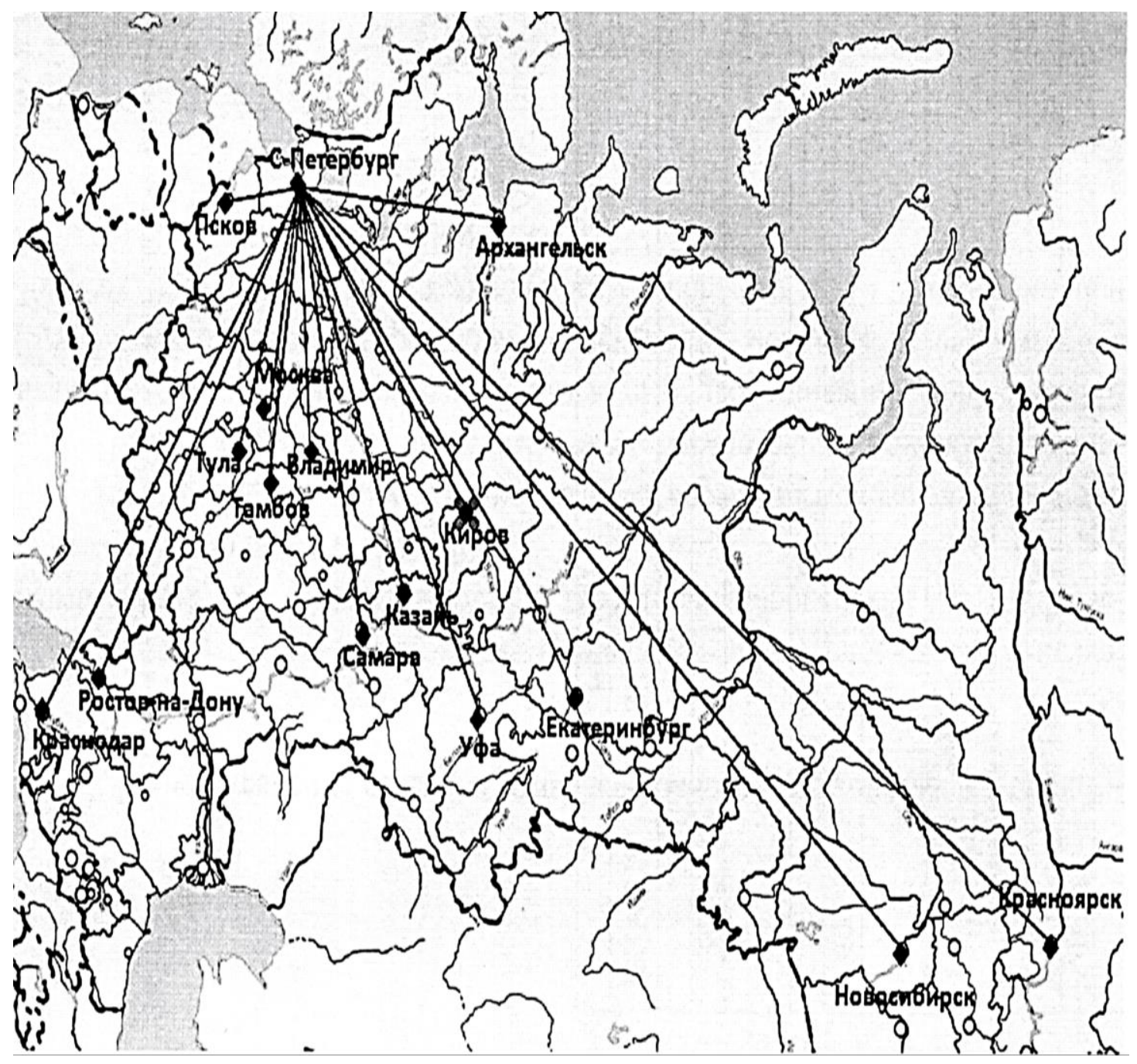

Рис. 2. Распространение селекции низкопентозановой озимой ржи на территории РФ (приводится из работы Кобылянский, Солодухина, 2015)

Fig. 2. Expansion of low-pentosan winter rye breeding in the Russian Federation (from Kobylyansky, Solodukhina, 2015)

Благодаря этому к настоящему времени селекция зернофуражной низкопентозановой ржи осуществляется на территории Европейской части РФ, и в Западной и Восточной Сибири РФ.

Использование кормовой иенности зерна сортов низкопентозановой ржи

Первые «модельные» эксперименты по определению кормовой ценности низкопентозановой ржи провели на лабораторных крысах. При скармливании зерна с низким $(0,51 \%)$ содержанием водорастворимых пентозанов молодым крысам в течение 36 суток, полученный прирост живой массы особей был на 20\% выше, чем при кормлении свиным комбикормом (рис. 3a).
В другом эксперименте выявлено превосходство зерна низкопентозановой ржи над пшеницей и ячменем (рис. 3б). Установлено, что средний прирост каждой лабораторной крысы через 28 дней кормления зерном низкопентозановой зернофуражной ржи составил $64,5 \%$ к начальному весу, что на 12,2\% выше, чем при кормлении зерном ячменя и на 26,9\% выше, чем при кормлении пшеницей (Lunegova, Kobylyansky, Solodukhina, 2014).

Проведенные исследования на крысах показали, что зерно новой ржи в цельном виде охотно поедается и эффективно переваривается животными.. 


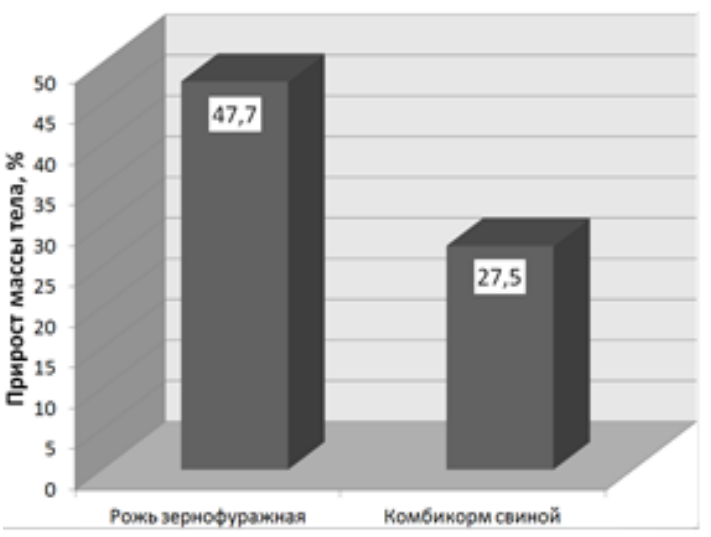

a

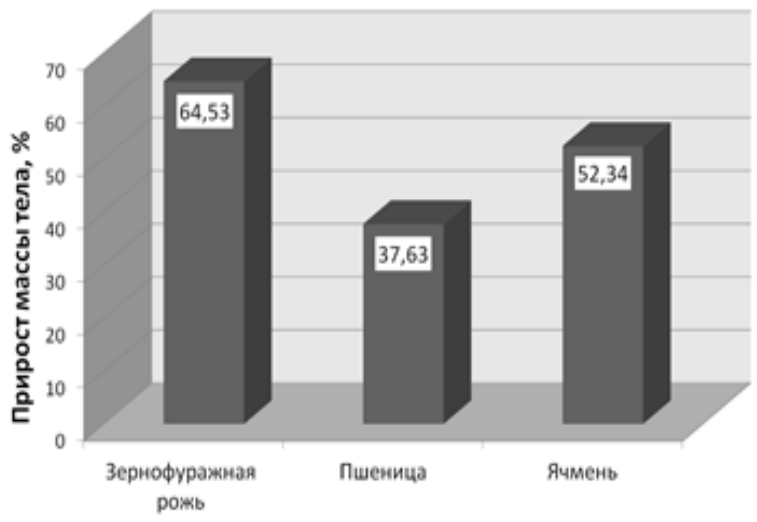

6

Рис. 3. Прирост массы тела молодых крыс при кормлении зерном низкопентозановой зернофуражной ржи в сравнении с комбикормом свиным (а)

и другими видами кормов (б)

(Санкт-Петербургская государственная академия ветеринарной медицины, 2014; приводится из работы Кобылянский, Солодухина, 2015)

Fig. 3. Weight increase of young rats when fed with low-pentosan forage rye grain as compared with mixed pig fodder (a) and other forages

(b) (St. Petersburg State Academy of Veterinary Medicine, 2014; from Kobylyansky, Solodukhina, 2015)

Испытание низкопентозановой ржи в рационах для свиней провели при использовании зерна сорта 'Вавиловская'. При кормлении поросят в течение восьми недель, при их «доращивании», использовали «экспериментальный» рацион (табл. 2), в котором зерновые культуры из «контрольного» рациона на 53\% заменили зерном низкопентозановой ржи и исключили дорогостоящие пищевые добавки (сухое молоко, премикс).
Все это привело к увеличению прироста животных на 44,5\% и снижению конверсии корма на 41,7\% по сравнению с контролем (рис. 4). Опыт по применению низкопентозановой ржи в рационе цыплят-бройлеров проведен в крестьянско-фермерском хозяйстве «Радушкино» в 2015 г. (Ленинградская обл.). При создании экспериментального рациона зерно пшеницы заменили зерном низкопентозановой ржи (табл. 3).

Таблица 2. Рационы для кормления поросят, используемые в ООО «Озерский свинокомплекс» (Тульская обл., 2013 г.)

Table 2. The diets used for feeding piglets at Ozersk Pig Farm (Tula, 2013)

\begin{tabular}{l|l}
\multicolumn{1}{c|}{$\begin{array}{c}\text { Контрольный рацион } \\
\text { The control diet }\end{array}$} & \multicolumn{1}{c}{\begin{tabular}{c}
\multicolumn{1}{c}{ Экспериментальный рацион } \\
The experimental diet
\end{tabular}} \\
\hline- & Рожь низкопентозановая $-50 \%$ \\
\hline Пшеница $-25 \%$ & Пшеница $-15 \%$ \\
\hline Ячмень $-25 \%$ & Ячмень -10\% \\
\hline Овес $-25 \%$ & Овес $-10 \%$ \\
\hline Кукуруза $-10 \%$ & Кукуруза - 10\% \\
\hline Трикальцийфосфат -5\% & Трикальцийфосфат -5\% \\
\hline Соль поваренная & Соль поваренная \\
\hline Сухое молоко -5\% & - \\
\hline Премикс 51-5\% & - \\
\hline
\end{tabular}




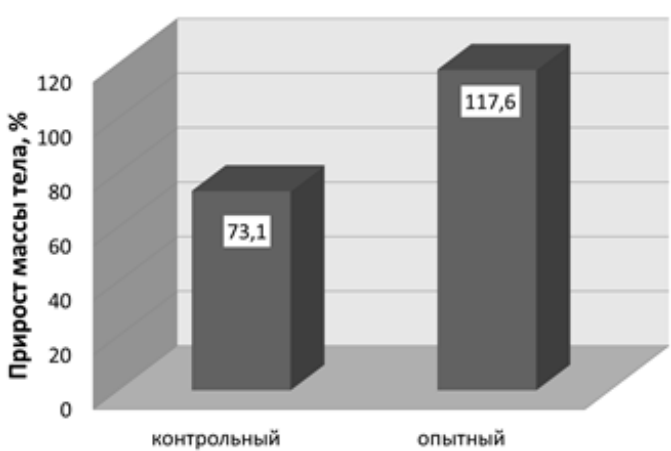

a)

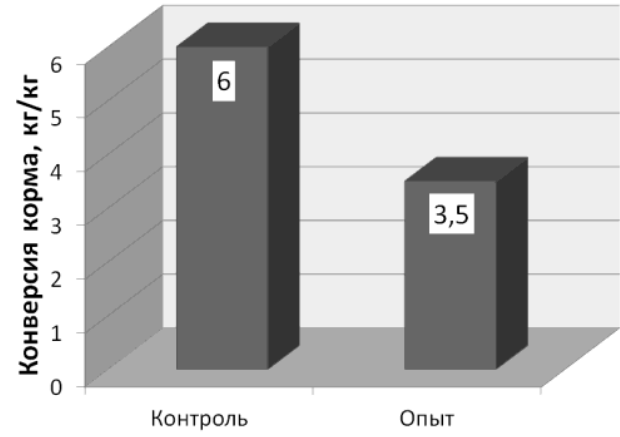

б)

Рис. 4. Прирост массы тела (а) и конверсия корма (б), используемого при кормлении поросят в ООО «Озерский свинокомплекс» (Тульская обл., 2013 г.)

Fig. 4. Increase in pig weight when piglets were fed with low-pentosan forage rye grain (a) and fodder conversion (b) as compared with patented mixed pig fodder at Ozersk Pig Farm (Tula, 2013)

Установлено, что при использовании, как контрольного, так и экспериментального рационов в кормлении бройлерных цыплят, прирост массы птиц был одинаковым. Через 46-48 дней кормления масса каждой особи достигла 2,4-2,5 кг.

Полученные результаты свидетельствуют о возможности успешного использования зерна низкопен-тозановой ржи при кормлении птицы.
Кормовое превосходство зерна новой ржи по сравнению с традиционной хлебопекарной рожью обусловлено тем, что низкое содержание пентозанов в зерне не приводит к образованию слизей в желудке животных, приводящих к возникновению проблем в пищеварении. Это позволяет животным эффективно и полно использовать высокоценные вещества низкопентозанового зерна такой ржи.

Таблица 3. Рационы, используемые для кормления цыплят-бройлеров (Санкт-Петербург, 2016 г.)

Table 3. The diets used for feeding broiler chicken (St. Petersburg, 2016)

\begin{tabular}{l|l}
\hline \multicolumn{1}{c|}{$\begin{array}{c}\text { Контрольный рацион } \\
\text { The control diet }\end{array}$} & \multicolumn{1}{c}{$\begin{array}{c}\text { Экспериментальный рацион } \\
\text { The experimental diet }\end{array}$} \\
\hline Молочно-протеиновый концентрат $-44 \%$ & Молочно-протеиновый концентрат $-44 \%$ \\
\hline Пшеница $-52 \%$ & Рожь низкопентозановая $-52 \%$ \\
\hline Масло подсолнечное $-0,5 \%$ & Масло подсолнечное $-0,5 \%$ \\
\hline Монокальций фосфат $-0,6 \%$ & Монокальций фосфат $-0,6 \%$ \\
\hline Известняковая мука $-1,6 \%$ & Известняковая мука $-1,6 \%$ \\
\hline Премикс 51-1\% & Премикс $51-1 \%$ \\
\hline
\end{tabular}

Исследование хлебопекарных свойств зерна у 10 сортов низкопентозановой ржи показало хорошие результаты. Низкое содержание $(0,51-0,68 \%)$ арабиноксиланов в зерне не привело к ухудшению их хлебопекарных качеств. Отмечено ускорение созревания теста и более длительная его устойчивость к размягчению (Lavrentyeva, Kunetsova et al., 2016). Сорта ржи нового поколения с низким содержанием водорастворимых арабиноксиланов в зерне характеризуются хорошими хозяйственно ценными качествами и пригодны для универ- сального использования. В связи с этим нет необходимости выводить сорта целевого зернофуражного направления. Низкопентозановая рожь становится экономически привлекательной и конкурентоспособной по отношению к другим зерновым культуpam.

Материаль представленных исследований были доложены на международной конференции EUCARPIA по генетике и селекиии ржи в Польше (Kobylyansky, Solodukhina, Lunegova, Novikova, 2015). 


\section{References/Литература}

Boros D. Quality aspects of rye for feed purposes. Vortr. Pflanzenzbcht, 2007, vol. 71, pp. 80-85.

Boros D., Lukaszewski A., Aniol A. Location of genes controlling of dietary fibre and arabinoxilans in rye. Proceedings of the EUCARPIA Rye Meeting (Juli 4-7), Radzicow, Poland, 2001, pp. 78.

Cyran M., Rakowska M., Wasilewko J., Buraczewska L. Degradation of dietary fiber polysaccharides of rye in the intestinal tract of growing pigs used as a model animal for studying digestion in humans. Jn. Anim. Feed Sci., 1995, vol. 4, pp. 217-227.

Dimenshtein F. I., Ermakov A. I. et all. Rye biochemistry // Biohimija kul'turnyh rastenij - Cultivated plants biochemistry, 1958, no. 1, pp. 165-232 [in Russian] (Дименштейн Ф.И., Ермаков А. И. и др. Биохимия ржи // В кн.: Биохимия культурных растений. 1958. № 1. C. 165-232).

Ficev A. I., Kosolapov V. M. Zootehnicheskaja ocenka ispol'zovanija rzhi $\mathrm{v}$ racionah sel'skohozjajstvennyh zhivotnyh // In: Ozimaja rozh': selekcija, semenovodstvo, tehnologii, pererabotka [in Russian] (Фицев А. И., Косолапов $B$. M. Зоотехническая оценка использования ржи в рационах сельскохозяйственных животных // В кн.: Озимая рожь: селекция, семеноводство, технологии, переработка. 2008, C. 110-119).

Kazakov E. D. Quantitative ratio and ash content of rye grain component parts // Reports of Science Academy of USSR, 1947, vol. 58, no. 6, pp. 1081-1082 [in Russian] (Казаков Е. Д. Количественное соотношение и зольность составных частей зерна ржи // ДАН СССР. 1947. T. 58. № 6. С. 1081-1082).

Kobilanskii V., Solodukhina O. Possibilities of winter rye breeding for low content of water soluble arabinixylans' in grains. EUCARPIA International Symposium on Rye Breeding \& Genetics (29 June - 2 July). Minsk, Belarus, 2010, pp. 57-61.

Kobylansky V. D., Solodukhina O. V. The role of the of the Vavilov Institute of plant industy in the initiation and development of new trends in winter rye breeding in Russia // Proceedings on applied botany, genetics and breeding, vol. 176, iss. 1, pp. 5-19 [in Russian] (Кобылянский В. Д., Солодухина О. В. Роль ВНИИ растениеводства им. Н. И. Вавилова в инициации и становлении новых направлений в селекции озимой ржи в России // Тр. по прикл. бот., ген. и сел. 2015. Т. 176. Вып. 1. С. 5-19).

Kobylianskii V., Solodukhina O., Lunegova I., Novikova S. Rye breeding for low water soluble pentosans and possibility of its use in animal feeding. EUCARPIA International Symposium on Rye Breeding \& Genetics, Abstracts of Oral Presentations and Posters (24-26 June), Wrocław, Poland, 2015, pp. 57.

Kobylyansky V. D. Rye. Genetically bases of rye breeding. Moscow: Kolos, 1982, 271 p. [in Russian] (Кобылянский В. Д. Рожь. Генетические основы селекции. М.: Колос, 1982. 271 c.)

Kobylyansky V. D., Solodukhina O. V. The bases of low pentosanes' rye breeding // Bulletin of applied botany, genetics and plant breeding, 2009, vol. 166, pp. 112-118 [in Russian] (Кобылянский В. Д., Солодухина О. В. Основы селекции малопентозановой ржи // Тр. по прикл. бот., ген. и селекции. 2009. Т. 166. С. 112118).

Kobylyansky V. D., Solodukhina O. V. Theoretical bases of fodder rye breeding with low watersoluble pentosans content // Agricultural Biology, 2013, no. 2, pp. 31-39 [in Russian] (Kобьлянский В. Д., Солодухина О. В. Теоретические основы селекции зернофуражной ржи с низким содержанием водорастворимых пентозанов // Сельскохозяйственная биология. 2013. № 2. C. 31-39).

Lavrentyeva N. S., Kuznetsova L. I., Kobylyansky V. D., Zhirnova E. V. Baking properties of the rye flour with a low content of water-soluble pentosans // Hlebopechenie Rossii, 2016, no. 6, pp. 31-33 [in Russian] (Лаврентьева Н. С., Кузнецова Л. И., Кобылянский В. Д., Жирнова Е. $B$. Хлебопекарные свойства муки из зерна ржи с низким содержанием водорастворимых пентозанов // Хлебопечение России. 2016. № 6. C. 31-33).

Lunegova I., Kobylyanskii V., Soloduhina O. Lowpentosans rye seeds - valuable concentrated feed for animals // International Bulletin of Veterinary Medicine, 2014, no. 2, pp. 30-37 [in Russian] (Лунегова И. В., Кобылянский В. Д., Солодухина О. В. Низкопентозановое зерно ржи - ценный концентрированный корм для животных // Международный вестник ветеринарии. 2014. № 2. С. 30-37).

Lyubarskii L. N. Rye. (Biological and technological grain properties) (Rozh' (Biologotehnologicheskie svojstva zerna), Moscow: Hlebizdat, 1956, 260 p. [in Russian] (ЛюбарскийЛ. Н. Рожь (Биолого-технологические свойства зерна). М.: Хлебиздат, 1956. 260 с.).

Pleshkov B. P. The cultivated plants biochemistry (Biohimija sel'skohozjajstvennyh rastenij). Moscow, 1965. 447 p. [in Russian] (Плешков Б. П. Биохимия сельскохозяйственных растений. М., 1965. 447 с.)

Schmalz H. Pflanzenzüchtung. Berlin, 1969, 278 p. 
DOI: 10.30901/2227-8834-2017-1-41-47

УДК 633.13:631.527

ОРИГИНАЛЬНАЯ СТАТЬЯ

Т. Е. Кузнецова,

С. А. Левштанов,

Н. В. Серкин

Общество с ограниченной

ответственностью

«Агростандарт»

350000, г. Краснодар,

ул. Октябрьская, 135/81

e-mail: Agrostandart.dr@list.ru

Ключевые слова:

овес, коллекция, сорт, линия, отбор, открытое ияветение, перекрестное опьление, рекомбиногенез, мутация

Поступление:

19.01.2017

Принято:

06.03.2017

\section{СЕЛЕКЦИЯ ОВСА НА КУБАНИ}

Актуальность. Овес (Avena sativa L.) - важнейшая фуражная и продовольственная культура, обладающая широкой экологической адаптивностью. Содержание в зерне белков, углеводов, жиров, витаминов, микроэлементов является оптимальным для нормальной жизнедеятельности человека и животных. В России в основном возделывается яровой овес, его площади сосредоточены в Сибирском, Приволжском и Центральном Федеральных округах. Доля Северо-Кавказского округа в производстве этой культуры составляет 1,5-3,2\%. В последние годы возрос спрос сельхозтоваропроизводителей на овес. Районированные сорта крайне нестабильны по годам по урожайности. Материал и методы. 20 линий, отобранных из урожайных сортов овса были изучены В 2014 году ООО «Агростандарт» передал на Государственное испытание два сорта ярового овса: 'Десант' и 'Ассоль'. Результаты и заключение. 'Десант' (A. sativa var. diffuse aristata Kc.) получен методом индивидуального отбора из шведского сорта 'Magne'. Метелка прямостоячая, средней длины. Высота растения 60-95 см. Сорт высокоустойчив к полеганию, среднеспелый. Продуктивная кустистость 1,0-1,7 стеблей. Масса 1000 зерен 27,3-39,6 г. По натуре зерна превосходит 'Валдин 765' на 15 г. Обладает хорошей полевой устойчивостью к корончатой ржавчине и пыльной головне. Урожайность за 4 года составила 37,3 ц/га, что выше стандарта на $11 \%$. Максимальная урожайность в КСИ составила 53,8 ц/га. Сорт 'Ассоль' (А. sativa var. diffuse mutica $\mathrm{Al}$.) - результат индивидуального отбора из сорта 'Краснодарский 73'. Среднеспелый. Высота растений 68-105 см, устойчив к полеганию. Метелка прямостоячая, пирамидальная, рыхлая, длина 20-25 см. Зерно харьковского типа, мелкое, масса 1000 зерен - 23,2-34,7 г. Длина метелки, число зерен в метелке, масса зерна с метелки и натура зерна свидетельствует о лучшей устойчивости сорта к абиотическим и биотическим стрессам. В среднем за 4 года (2012-2015 гг.) урожайность составила 36,6 ц/га, что выше 'Валдина 765 ' на 2,8 ц/га. Максимальная урожайность - 52, 4 ц/га. 
T. E. Kuznetsova,

S. A. Levshtanov, N. V. Serkin

AGROSTANDART Limited Liability Company 135/81

Oktyabrskaya St.,

Krasnodar 350000

e-mail: Agrostandart.dr@list.ru

Key words:

oats, collection, variety, line, selection, open flowering, cross-pollination, recombination, mutation

Received:

19.01.2017

Accepted:

06.03.2017

\section{OAT BREEDING IN THE KUBAN REGION}

Background. Oat (Avena sativa L.) is an important forage and food crop. In Russia, mainly spring oat is cultivated, and its area is concentrated in the Siberian, Volga and Central Federal Districts. The share of the North Caucasus Federal District in the production of this crop is only 1.5 to $3.2 \%$, and that of the Krasnodar Territory is even less. In recent years, the demand of agricultural producers for oat has significantly grown. Commercialized cultivars are extremely unstable year by year in their productivity. Material and methods. Twenty lines were allowed to participate in the competitive variety trials. According to the results of the three-year study, two cultivars - 'Desant' and 'Assol' - were submitted for the state trials. Results and conclusions. 'Desant' was obtained by individual selection from the Swedish cultivar 'Magne'. It belongs to the A. sativa var. diffuse aristata $\mathrm{Kc}$. The panicle is erect of average length. Plant height is $60-95 \mathrm{~cm}$. The cultivar is highly resistant to lodging. Productive tillering capacity is $1.0-1.7$ stems. It is ripening midseason, with the 1000 grain weight of $27.3-39.6 \mathrm{~g}$. Its grain-unit exceeds 'Valdin 765 ' by $15 \mathrm{~g}$. This cultivar has good field resistance to crown rust, and is resistant to semiloose smut of oats. The average yield over 4 years was $3.73 \mathrm{t} / \mathrm{ha}$, which is higher than the reference by $11 \%$. The highest yield of $5.38 \mathrm{t} / \mathrm{ha}$ was obtained when preceded by white mustard. The cultivar 'Assol' was the result of individual selection from cv. 'Krasnodarsky 73'. It belongs to the A. sativa var. diffuse mutica Al__Its growing season attributes it to midseason varieties. Plant height is $68-105 \mathrm{~cm}$; the cultivar is resistant to lodging._Its panicle is erect, pyramidal, loose, with average length of $20-25 \mathrm{~cm}$. The grain is Kharkiv-type, small; the weight of 100 grains is $23.2-34.7 \mathrm{~g}$ at the level of the reference. Its panicle length, number of grains per panicle, grain weight per panicle and grain-unit attest to the cultivar's better resistance to abiotic and biotic stresses. On the average over 4 years (2012-2015), its yield was $3.66 \mathrm{t} / \mathrm{ha}$, which is higher than 'Valdin 765 ' by $0.28 \mathrm{t} / \mathrm{ha}$. The highest yield obtained was $5.24 \mathrm{t} / \mathrm{ha}$. 


\section{Introduction}

Oat (Avena sativa L.) is one of the most important forage and food crop. It grows on all continents of the world. It is widespread due to its variety of forms, adapted to specific soil and climatic conditions. Compared to other crops, oats is less demanding as regards the soil; it can utilize hard soluble soil elements and late rainfall. One of the oat's advantages is its tolerance to soil acidity.

Oat entered the human diet significantly later than other grains. Until the 1930s it was used exclusively as livestock feed. The nutritional value of this crop's grain is taken as a unit.

Oat is the "treasury" of nutrients and biologically active substances, vitamins and microelements essential for normal life and good health of both humans and animals. The optimal combination of grain proteins, carbohydrates and fats, a relatively high content of selenium and silicon, the presence of $\beta$-glucan and avenantramides make oat a valuable immunomodulator (Loskutov, 2007). The most valuable characteristics is the high content of fiber from the water-soluble group called (1-3; $1-4) \beta$-d-glucans in the endosperm cell walls.

It has been found that $\beta$-glucans have a marked cholesterol-lowering effect and are natural antioxidants. Taking into consideration the areas under oats, this crop is the fifth after wheat, rice, maize and barley in the world production of grain. The main oat cultivation areas are in the countries with temperate climate. The last fifteen years have seen an annual reduction in oat production. In 2012, due to the reduced areas and drought the shortage of oat grain was $9.0 \%$ as compared with 2011.

In Russia, the acreage under oats and oat grain production declined by more than $60 \%$. In 1990, oats were planted over the area of 9,100 thousand hectares ( $\mathrm{t} / \mathrm{ha}$ ), but in 2012 only $3,241 \mathrm{t} / \mathrm{ha}$ of arable land were planted, in 2013, 3.324 t/ha, and in 2014, 3.248.7 thou. ha. According to Russian statistics, during the past 10 years the area under oats has decreased by $8.6 \%$. The reasons are the underestimation of the role of oats for human healthy nutrition, lack of understanding of the importance of this crop as a fodder, and, of course, an overall reduction of livestock. However, despite the significant reductions, Russia remains the world's leader in oat production. According to the statistics, the gross yield of oat grain is closely linked with the sowing area $(h=0.30 \ldots 0.94)$, while the contribution to the yield defined by a variety, quality of the seeds and breeding technology is significantly lower $(h=0.18 \ldots 0.19)$ (Botalova, 2013). However, some positive trend in yields should be noted. In 2014, the yield of oats in Russia amounted to $1.71 \mathrm{t}$ per hectare of harvested area, in 2013, $1.64 \mathrm{t} / \mathrm{ha}$, while in the early 1990s it did not exceed 0.12 t/ha. Spring oat is cultivated mainly in Siberian, Volga and Central Federal Districts. The share of the North Caucasus region in the production of this crop is only $1.5-3.2 \%$, and the share of Krasnodar region is even less.

Cultivated oat (Avena sativa L.) with the genomic composition AA SS DD in our region is represented by spring and winter forms. The first cultivars were obtained by individual selection from local varieties - populations. In the 1930s, the main areas under oats in Krasnodar region were occupied with one of these varieties - 'Kharkovsky 596'. In the 1950s, such cultivars as 'Lokhovsky', 'Victory', 'Leytevitsky' and 'Sovetsky' obtained by inter-variety hybridization and subsequent individual selection from a hybrid population were planted. In 1968, the spring oat 'Krasnodarsky 73' was commercialized. This cultivar was obtained in Krasnodar Agricultural Research Institute under the direction of V. N. Gromachevsky by crossing the collection local sample 'Bendery' with cv. 'Sovetsky'. 'Krasnodarsky 73' ripened 2-6 days earlier than 'Lgovsky 1026', and its yield exceeded the latter by $0.3-0.4 \mathrm{t} / \mathrm{ha}$. Another achievement of the Krasnodar oat breeding was the spring oat cultivar 'Zelenyi'. With the help of chemical mutagenesis Academician V. M. Shevtsov was able to induce a large number of mutants valuable for breeding: dwarf and second growth forms with a strong stem, with altered growing period, coarse-grained mutants, forms with improved grain quality. One of the mutants, called var. 'Zelenyi', proved to be suitable for direct reproduction. After the successful state trials in 1976, it was included in the State Register and has been cultivated in 8 regions of the country. The cultivar was obtained as a result of treating seeds with a chemical mutagen nitrosoethylurea $(0.05 \%$ for 24 hours $)$. Its late panicle emergence - 20-25 days later - made it an important link in the organic chain, especially when there is a shortage of rich fodder. Winter oat is a relatively young crop. In the absence of frost resistant forms its distribution is limited. Therefore, its main sowing areas are concentrated in the countries with a mild climate. Practical experience proved the possibility of effective cultivation of winter oats in 
southern and suburban areas of the North Caucasus (Gudkova, 2011). If compared with spring oats, it forms 1.5-2.0 times higher grain yield and green mass (Schepetkov, Boytsova, 1974). Breeding of winter oats is carried out in Western Europe, North America, Australia and Russia. The Adygea Agricultural Research Institute has developed 10 varieties, 5 of which are approved for cultivation.

A breeder has got a nice choice of methods and new breeding approaches whose efficiency has been tested on a number of crops, including oats. The largest number of oat cultivars have been produced by Russian breeders. Currently, in the Russian State Register of breeding achievements there are 108 spring oat varieties and 5 winter ones.

Recently, farmers of Krasnodar region have taken interest in this crop. Perhaps, it has been induced by the increase in the acreage of areas under acidic soils due to systematic application of physiologically acidic fertilizers. There are 271.7 thou. ha of acidic soils in the region, 13.1 thou. ha of which are highly acidic (Romanenko et al., 2015). According to the data available in the specialized literature, the loss of bases $(\mathrm{Ca}$ and $\mathrm{Mg})$ due to leaching of carbonate chernozem is much higher than that of acid, and the loss rate increases with the application rates of physiologically acidic fertilizers. When the fertilizer application norms are increased twice, the loss of bases is $20-28 \%$ (Kozlovskiy et al., 1980).

Currently, two cultivars of spring oats 'Valdin 765' and 'Skakun' - are cultivated in the region. Due to the lack of drought resistance they are extremely unstable in yields from year to year, and in a droughty year the yield is twice or even more times less.

The grain market statistics shows the need to develop more adaptable cultivars with high productivity potential, which would be more drought-resistant, resistant to lodging and diseases in the region with its highly variable soil and climate environments and dramatically changing weather conditions over the years.

Successful breeding depends much on the diversity of the genetic source material. That is why the worldwide collection of VIR comprising 13,000 oat accession of various geographic origin is very important for oat breeding.

The initial stage of the breeding work is a comprehensive study of the collection accessions, released cultivars and promising material obtained in other institutions, and selection of parental pairs for crossing. The breeders of LLC "Agrostandart" studied 29 collection accessions kindly granted by VIR, and they revealed heterogeneity of genotypes in the length of growing season, plant height, panicle shape, grain color, and grain weight per panicle. It is known that the majority of self-pollinating crops, including oats, are to a greater or lesser prone to open flowering and cross-pollination. Weather conditions greatly influence the process of flowering. In hot and dry weather, the number of openly blooming flowers increases, and, therefore, the possibility of crosspollination increases as well. The number of open flowers on hulless oats reaches $10 \%$. In view of this, it is necessary to emphasize the relative permanence of pure lines and varieties. Genotypes with new features and properties appear due to the influence of natural recombinogenesis and mutations in a variety. According to our data, this is the real cause of higher variability in the above-listed characteristics of the studied varieties. For example, the winter barley cultivars 'Zimur', 'Kondrat' and 'Pharaon' differ in frost resistance, length of growing season, resistance to lodging and diseases, though they have the same ancestor variety 'Dobrynya 3' (Kuznetsova, Serkin, 2006; Kuznetsova et al., 2013).

\section{Material and methods}

About 350-420 panicles were collected from each of seven varieties: 'Krasnodarsky 73', 'Kubansky', 'Zelenyi', 'Skakun', 'Valdin 765', 'Magne', and 'S. Romao'. After thorough screening in a breeding nursery, 312 families were selected for further study. Only 20 lines were allowed to participate in the competitive variety trials. According to the results of the three-year study, two cultivars - 'Desant' and 'Assol' - were submitted for the state trials.

\section{Result and conclusion}

Cv. 'Desant' was obtained by individual selection from the Swedish variety 'Magne'. It belongs to the A. sativa var. diffuse aristata Kc. Its panicle is erect, flattened, its length is average. Plant height is $60-95 \mathrm{~cm}$. The cultivar is highly resistant to lodging. Productive tillering is 1.0-1.7 stems. As far as the length of the growing season is concerned, it is considered a mid-season variety (table 1). 
Таблица 1. Основные показатели ярового овса сорта 'Десант' Table 1. Main characteristics of the spring oat cultivar 'Desant'

\begin{tabular}{|c|c|c|c|c|c|}
\hline \multirow[b]{2}{*}{ Characteristics } & \multirow[b]{2}{*}{ Desant } & \multirow{2}{*}{$\begin{array}{c}\text { Reference } \\
\text { var. Val- } \\
\text { din } 765\end{array}$} & \multirow{2}{*}{$\begin{array}{l}\text { Parent } \\
\text { Magne }\end{array}$} & \multicolumn{2}{|c|}{ Tolerance } \\
\hline & & & & Reference & Parent form \\
\hline $\begin{array}{l}\text { Growing season dura- } \\
\text { tion, days }\end{array}$ & 105 & 108 & 103 & -3.0 & +2.0 \\
\hline Productivity, t/ha & 3.73 & 3.37 & 3.41 & +3.6 & +3.2 \\
\hline Plant height, $\mathrm{cm}$ & 80 & 85 & 80 & -5.0 & 0 \\
\hline 1000 grain weight, $\mathrm{g}$ & 32.0 & 28.0 & 31.1 & +4.0 & +0.9 \\
\hline $\begin{array}{l}\text { Productive tillering, } \\
\text { stems }\end{array}$ & 1.3 & 1.1 & 1.3 & +0.2 & 0 \\
\hline Panicle length, $\mathrm{cm}$ & 26 & 22 & 22 & +4.0 & +4.0 \\
\hline $\begin{array}{l}\text { Grain number in the } \\
\text { main panicle, pieces }\end{array}$ & 102 & 86 & 92 & +16.0 & +6.0 \\
\hline $\begin{array}{l}\text { Grain weight of the main } \\
\text { panicle, } g\end{array}$ & 3.2 & 2.4 & 2.8 & +0.8 & +0.4 \\
\hline Grain-unit, $\mathrm{g}$ & 471 & 456 & 467 & +15.0 & +4.0 \\
\hline $\begin{array}{l}\text { Content of raw protein, } \\
\%\end{array}$ & 11.9 & 11.4 & 11.8 & +0.5 & +0.1 \\
\hline
\end{tabular}

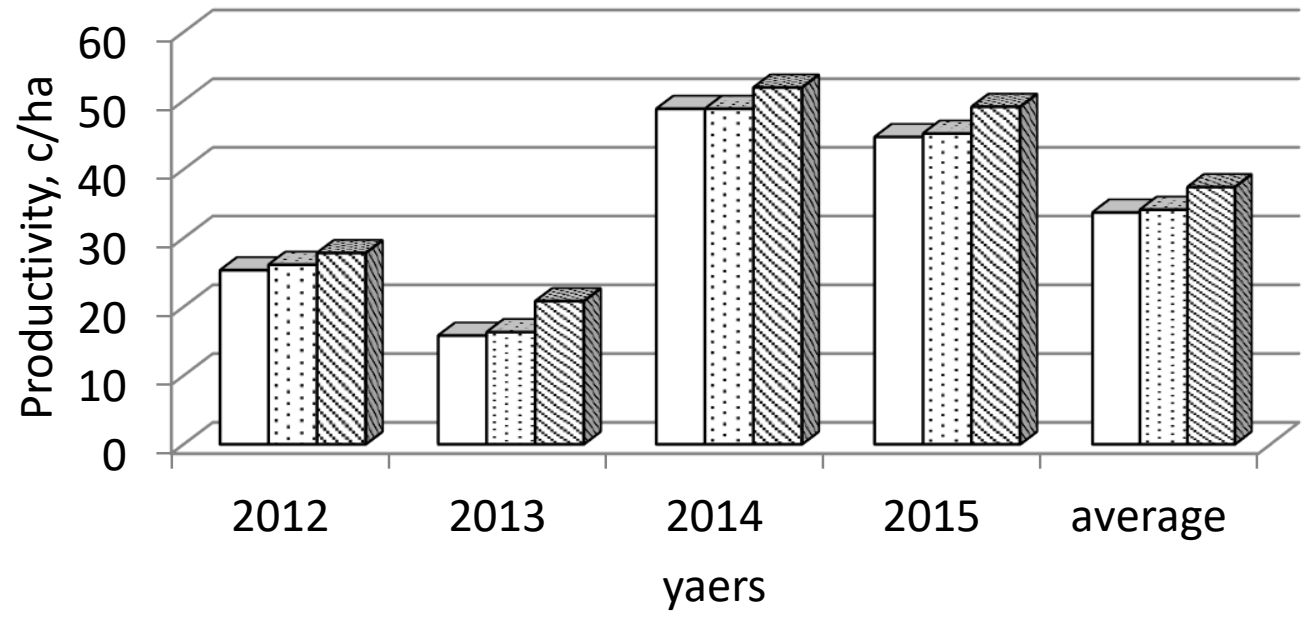

Valdin 765 - st. $\quad$ Magne $\square$ Desant

Рис. 1 Урожайность сорта ярового овса Десант в сравнении со стандартом 'Валдин 765' и родительским сортом 'Magne'

Fig. 1 Productivity of the spring oat cultivar 'Desant' as compared with the reference 'Valdin 765' and the parent cv. 'Magne'

Mathematical processing (LSD 05$)$ has shown that in the competitive trial nursery the yield increase was $0.24 \mathrm{t} / \mathrm{ha}$.

The cultivar matures 2-3 days earlier than 'Valdin 765 ' and 2 days later than 'Magne'. Grain size is medium, grain base is bare, and grain shape is semilong (Moscow type). Depending on the prevailing weather conditions, the mass of 1000 grains ranged from $27.3 \mathrm{~g}$ (2012) to $39.6 \mathrm{~g}$ (2014) which is higher than the reference 'Valdin 765 ' by $21.8-15.4 \%$.

The cultivar is more resistant to abiotic stress than the commercialized varieties. It demonstrates good field resistance to Puccinia coronifera Kleb., and is almost resistant to $U_{S-}$ tilago avenae (Pers.) Rost. The above- 
mentioned characteristics enable 'Desant' to yield good harvest. The average yield for 4 years has been $3.73 \mathrm{t} / \mathrm{ha}$, which is higher than that of 'Valdin 765 ' by $11 \%$ (fig. 1). Maximum productivity in the competitive variety trials obtained with white mustard as a preceding crop was $5.38 \mathrm{t} / \mathrm{ha}$.

The cultivar 'Assol' was the result of individual selection from cv. 'Krasnodarskiy 73'.
It belongs to the A. sativa var. diffuse mutica Al. Its growing season attributes it to midseason varieties: it forms a panicle and matures similarly to 'Valdin 765 ' and one day ahead of the parent cultivar. Plant height is $68-105 \mathrm{~cm}$. The cultivar is resistant to lodging. The panicle is erect, pyramidal, semicompressed, loose, with average length of $20-25 \mathrm{~cm}$.

\section{Таблица 2. Основные показатели ярового овса сорта 'Ассоль' Table 2. Main characteristics of the spring oat cultivar 'Assol'}

\begin{tabular}{|c|c|c|c|c|c|}
\hline \multirow{2}{*}{ Characteristics } & \multirow{2}{*}{ Assol } & \multirow{2}{*}{$\begin{array}{c}\text { Refer- } \\
\text { encevar. } \\
\text { Valdin } \\
765\end{array}$} & \multirow{2}{*}{$\begin{array}{l}\text { Parent Kras- } \\
\text { nodarskiy } 73\end{array}$} & \multicolumn{2}{|c|}{ Tolerance } \\
\hline & & & & Reference & Parent form \\
\hline $\begin{array}{l}\text { Growing season } \\
\text { duration, days }\end{array}$ & 108 & 108 & 109 & 0 & -1.0 \\
\hline Productivity, t/ha & 3.65 & 3.37 & 3.24 & +2.8 & +3.6 \\
\hline Plant height, $\mathrm{cm}$ & 90 & 85 & 90 & +5.0 & 0 \\
\hline 1000 grain weight, $g$ & 27.8 & 28.0 & 27.1 & -0.2 & +0.7 \\
\hline $\begin{array}{l}\text { Productive tillering, } \\
\text { stems }\end{array}$ & 1.3 & 1.1 & 1.0 & +0.2 & +0.3 \\
\hline Panicle length, cm & 24 & 22 & 22 & +2.0 & +2.0 \\
\hline $\begin{array}{l}\text { Grain number in the } \\
\text { main panicle, pieces }\end{array}$ & 96 & 86 & 82 & +10.0 & +14.0 \\
\hline $\begin{array}{l}\text { Grain weight of the main } \\
\text { panicle, } g\end{array}$ & 2.7 & 2.4 & 2.2 & +0.3 & +0.5 \\
\hline Grain-unit, $\mathrm{g}$ & 461 & 456 & 456 & +5.0 & +5.0 \\
\hline $\begin{array}{l}\text { Content of raw protein, } \\
\%\end{array}$ & 11.9 & 11.4 & 11.9 & +0.5 & 0 \\
\hline
\end{tabular}

Mathematical processing $\left(\mathrm{LSD}_{05}\right)$ has shown that in the competitive trial nursery the yield increase was $0.24 \mathrm{t} / \mathrm{ha}$.

\section{Conclusion}

The grain is Kharkiv-type, small; the weight of 100 grains is $23.2-34.7 \mathrm{~g}$ at the reference's level. Its panicle length, number of grains per panicle, grain weight per panicle and grain-unit testify to the cultivar's better resistance to abiotic and biotic stresses. Resistance of cv. 'Assol' to Puccinia coronifera is higher than the average degree, and it is almost fully resistant to Ustilago avenae.

Ultimately, such combination of good characteristics has led to a yield increase. The average yield for 4 years (2012-2015) was 3.65 $\mathrm{t} / \mathrm{ha}$, which is higher than 'Valdin 765 ' by 0.28 t/ha, and higher than 'Krasnodarsky 73' by $0.36 \mathrm{t} / \mathrm{ha}$ (fig. 2). The highest yield obtained during the competitive variety trials was 5.24 t/ha with white mustard as a preceding crop.
The results of one-year state trials show high prospects of the new cultivars. Productivity of cv. 'Desant' on the variety testing plots in the Republic of Crimea and Stavropol region was higher than the reference by 0.20 $0.39 \mathrm{t} / \mathrm{ha}$, and that of cv. 'Assol' on the variety testing plots in Krasnodar and Stavropol regions exceeded the reference by $0.22-0.38$ $\mathrm{t} / \mathrm{ha}$. It should be mentioned that on the variety testing plots of Rostov region new cultivars showed equal productivity with 'Valdin 765', and they produced high-quality grain. Their 1000 grain weights were higher than reference's by $5.7-6.0 \mathrm{~g}$.

We hope that the cultivars 'Desant' and 'Assol' will successfully pass the state variety trials and play an important role in grain production 


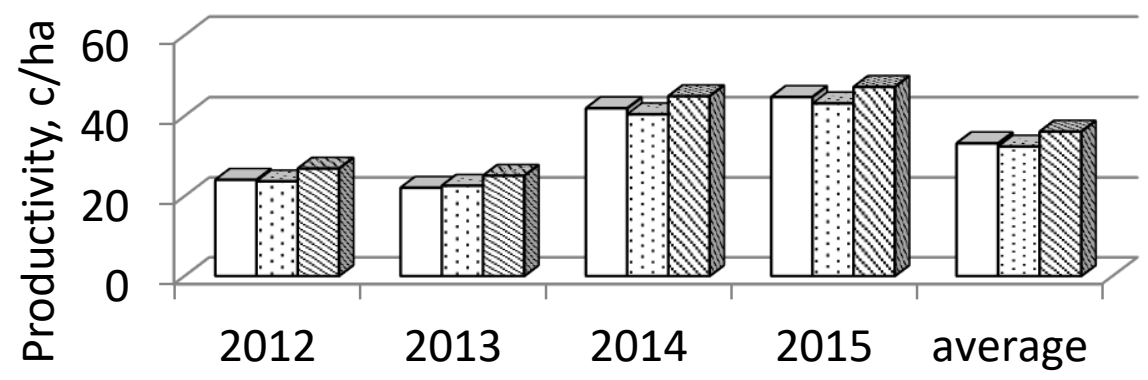

Valdin 765 - st. years Magne $\because$ Assol

\section{Рис. 2 Урожайность сорта ярового овса 'Ассоль' в сравнении с 'Валдин 765’ и родительским сортом 'Краснодарский 73'}

Fig. 2 Productivity of the spring oat cultivar 'Assol' as compared with the reference 'Valdin 765' and the parent cv. 'Krasnodarsky 73'

\section{References/Литература}

Loskutov I. G. Oats (Distribution, taxonomy, evolution and breeding value) -St. Petersburg: RSRIR, 2007, 448 p. [in Russian] (Лоскутов И. Г. Овес (Распространение, систематика, эволюция и селекционная ценность) СПб: ВНИИР, 2007, 448 с.).

Botalova G. A. Fodder grain of Russia // Proceedings on applied botany, genetics and breeding, 2013, vol. 171, pp. 131-135 [in Russian] (Боталова Г. А. Зернофуражные культуры России // Тр. по прикл. бот., ген. и сел. 2013. Т. 171. C. 131-135).

Gudkova G. N. Results of winter oat breeding in the Adygea Republic // Sustainable development of agriculture in modern conditions of the South (Collection of reports of the All-Russian Scientific \& Practical Conf., dedicated to the 50th anniversary of the Adygea Agricultural Research Institute). Part 2, Maikop, 2011, pp. 5257 [in Russian] (Гудкова Г. Н. Результаты селекции зимующего овса в Республике Адыгея // Устойчивое развитие АПК в современных условиях Юга России (Сб. докл. Всероссийской науч.-прак. конф., посвященной 50-летию ГНУ Адыгейский НИИСХ Россельхозакадемии). Часть 2. Майкоп, 2011. С. 52-57).

Schepetkov A. A., Boytcova V. P. The results of the work on winter pea and winter oat breeding in the Republic of Adygea// Collection of scientific works, Maikop: Adygea Department of Krasnodar Book Publishing House, 1974, iss. 111, pp. 37-45 [in Russian] (Щепетков A. A., Бойцова В. П. Итоги работы по селекции зи- мующего гороха и зимующего овса в Адыгее // Сб. науч. работ, Майкоп: Адыгейское отделение Краснодарского книжного изд-ва, 1974. Вып. 111. С. 37-45.

Romanenko A. A., Kildyushkin V. M., Lavrenchuk N. F., Shirinyan M. K., Soldatenko A. G., Kulik V. A., Zhyvotovskaya E. G., Levshtanov S. A., Kuznetcova T. E., Boyko A. P. Recommendations for the use of defecation sludge for liming acid soils in Krasnodar region. Krasnodar, 2015, 39 p. [in Russian] (Романенко А. А., Кильдюшкин В. М., Лавренчук Н. Ф., Ширинян М. Х., Солдатенко А. Г., Кулик В. А., Животовская Е. Г., Левштанов С. А., Кузнечова Т. Е., Бойко А. П. Рекомендации по применению дефеката для известкования кислых почв в Краснодарском крае. Краснодар, 2015. 39 с.). Kuznetcova T. E., Serkin N. V. Winter barley breeding for disease resistance in Krasnodar region. Krasnodar: Prosveschenie Yug Ltd., 2006, 287 p. [in Russian] (Кузнецова T. Е., Серкин Н. В. Селекция озимого ячменя на устойчивость болезням в Краснодарском крае. Краснодар: ООО «Просвещение Юг», 2006. 287 с.).

Kuznetcova T. E., Serkin N. V., Levshtanov S. A., Veretelnikova N. A. Combinational breeding of winter barley in Krasnodar Agricultural Research Institute // Proceedings on applied botany, genetics and breeding, 2013, vol. 171, pp. 208-213 [in Russian] Кузнецова Т. Е., Серкин Н. В., Левитанов С.А., Веретельникова Н. А. Комбинационная селекция озимого ячменя в Краснодарском НИИСХ // Тр. по прикл. бот., ген. и сел. 2013. Т. 171. С. 208-213). 
DOI: 10.30901/2227-8834-2017-1-48-57

УДК 635.657-152(571.1)

ОРИГИНАЛЬНАЯ СТАТЬЯ

\section{С. П. Кузьмина, \\ Н. Г. Казыдуб, \\ Е. А. Черненко}

Федеральное государственное бюджетное образовательное учреждение высшего образования «Омский государственный аграрный университет имени

П. А. Столыпина», 644008, Россия, г. Омск, ул. Институтская площадь, д.1, e-mail:sp.kuzmina@omgau.org

\section{Ключевые слова:}

нут, образец, признак, элементы урожайности, кластерный анализ

Поступление:

26.12.2016

Принято:

06.03.2017

\section{ПЕРСПЕКТИВЫ И РЕЗУЛЬТАТЫ ИЗУЧЕНИЯ КОЛЛЕКЦИИ НУТА В ОМСКОМ ГАУ}

Актуальность. В структуре посевных площадей Западной Сибири зернобобовые культуры занимают от 1 до $2 \%$, чего явно недостаточно. В связи с этим необходимо общее увеличение площадей под зернобобовыми культурами, расширение их ассортимента, а также внедрение в производство новых, нетрадиционных для региона бобовых культур, к которым относится нут, и выделение источников хозяйственно ценных признаков с целью создания новых сортов пригодных для возделывания в условиях южной лесостепи Западной Сибири. Материалы и методы. Изучение хозяйственно ценных признаков проводили в Учебно-опытном хозяйстве Омского ГАУ в 2012-2016 гг. у 23 коллекционных образцов нута, полученных из Всероссийского института генетических ресурсов растений имени Н. И. Вавилова (ВИР) и 23 образцов коллекции сомаклонов, полученных из Сибирского НИИ кормов. В качестве стандарта использовали районированный сорт 'Краснокутский 123'. Результаты и выводы. В результате исследований выделены источники отдельных хозяйственно ценных признаков нута: на сокращение вегетационного периода - C4Deemin, C7-Александрит, C14-Александрит, C15-Волгоградский 10, ILC10005 , С-82, C-83, 'Волгоградский 10'; на уменьшение высоты растения ILC-10005, 'Волгоградский 10', C4-Deemin; на увеличение числа семян c одного растения - ILC-2394, ILC-482, C-82, 'Волгоградский 10', ILC2402; на увеличение массы семян с растения - ILC-2394, ILC-10005, ILC3407 , ILC-482; на увеличение числа бобов с растения - C-243, C-18, C-17; на увеличение массы бобов с растения - C-243, C-18, C-17, C-303. Выделены образцы нута, имеющие высокую симбиотическую активность: С2Краснокутский 123, С8-Александрит, С5-Краснокутский 123 и С-82. Показана возможность использования кластерного анализа для комплексной оценки исходного материала в селекции нута. Установлен характер наследования основных хозяйственно ценных признаков: положительное сверхдоминирование наблюдается по массе и числу бобов с растения, массе и числу семян с растения; отрицательное сверхдоминирование - по высоте прикрепления нижнего боба; промежуточное наследование - по высоте растений и продолжительности вегетационного периода. Расчет коэффициента корреляции показал, что селекцию на повышение урожайности нута в условиях южной лесостепи Западной Сибири следует вести по числу семян, массе и числу бобов с растения. 


\section{S. P. Kuzmina, \\ N. G. Kazydub, \\ E. A. Chernenko}

The P. A. Stolypin Omsk State Agrarian University,

1, Institutskaya Square, Omsk, 644008, Russia,

e-mail: sp.kuzmina@omgau.org

Key words:

chickpea, accession, character, yield components, cluster analysis

Received:

26.12.2016

Accepted:

06.03.2017

\section{PROSPECTS AND RESULTS OF STUDYING THE COLLECTION OF CHICKPEA FROM VIR AT OMSK STATE AGRARIAN UNIVERSITY}

Background. In the structure of sown areas in West Siberia legumes occupy from 1 to $2 \%$, which is clearly not enough. With this in view, it is necessary to increase the total area under legumes, expanding their diversity, introducing new leguminous crops nontraditional for the region, such as chickpea, and identifying sources of valuable agronomic characters in order to develop new cultivars suitable for cultivation in the southern forest-steppe environments of West Siberia. Materials and methods. The study of agronomic traits was conducted at the Training and Experimental Farm of Omsk State Agrarian University in 2012-2016 on 23 chickpea accessions from the collection of the Vavilov Institute of Plant Genetic Resources (VIR) and 23 accessions from the collection of somaclones held by the Siberian Research Institute of Forages. The commercialized cultivar 'Krasnokutsky 123' was used as reference. Results and conclusions. As a result, the studies helped to identify sources of certain agronomic characters in chickpea: shorter growing season (C4-Deemin, C7Alexandrite, C14-Alexandrite, C15-Volgograd 10, ILC-10005, C-82, C-83 and 'Volgograd 10'); reduceed plant height (ILC-10005, 'Volgograd 10' and C4Deemin); increased number of seeds per plant (ILC-2394, ILC-482, C-82, 'Volgograd 10' and ILC-2402); increased seed weight per plant (ILC-2394, ILC-10005, ILC-3407 and ILC-482); increased number of pods per plant (C243, C-18 and C-17); and increased weight of pods per plant (C-243, C-18, C17 and C-303). Chickpea accessions with high symbiotic activity were identified (C2- Krasnokutsky 123, C-8 Alexandrite, C5-Krasnokutsky 123 and C82). The possibility of using cluster analysis for comprehensive assessment of source material for chickpea breeding was demonstrated. The nature of inheritance of major agronomic traits was disclosed: positive superdominance was observed in the weight and number of pods per plant, and weight and number of seeds per plant; negative superdominance was manifested by the height of the lower pod attachment; intermediate inheritance was demonstrated by the height of plants and length of the growing season. Calculation of the correlation coefficient showed that chickpea breeding for higher yields in the environments of the southern forest-steppe in West Siberia should be based on the number of seeds, and weight and number of pods per plant. 


\section{Введение}

Зернобобовые культуры имеют важное кормовое и продовольственное значение. Это делает их одинаково необходимыми для производства в любых природноэкономических условиях, при всех формах собственности и хозяйствования. Современное сельскохозяйственное производство располагает достаточно большим разнообразием зернобобовых культур: горох, фасоль, бобы, нут, соя, чечевица и др. В структуре посевных площадей Западной Сибири зернобобовые культуры занимают всего от 1 до 2\%, чего явно недостаточно. Причем из всего разнообразия семейства бобовых в Сибирском регионе возделывается в основном горох (Kazydub et al., 2016). В связи с этим, необходимо общее увеличение площадей под зернобобовыми культурами, расширение их ассортимента, а также внедрение в производство новых, нетрадиционных бобовых культур, к числу которых относится нут. Это возможно в Западной Сибири только при выведении и распространении новых хорошо адаптированных к местным условиям сортов (Kazydub et al., 2015; Kuz'mina et al., 2016; Rozhanskaja, 2009). В регионах, подверженных периодическому влиянию засухи (в том числе и югу Омской области), перспективной по биологическим особенностям может стать культура нута (Germanceva, 2014). Нут обладает высокой засухо- и холодоустойчивостью, технологичностью при уборке, устойчивостью к болезням и вредителям, высокой питательностью и многообразным использованием на пищевые цели, поэтому его возделывание может значительно стабилизировать производство высокобелкового зерна (Bulyncev, 2003; Vishnyakova et al., 2013; Rozhanskaja, 2005). Интерес сельскохозяйственных предприятий и крестьянско-фермерских хозяйств к этой культуре в регионе растет с каждым годом. Однако районированные сорта нута в условиях Омской области не полностью отвечают требованиям современного сельского хозяйства по продолжительности созревания и продуктивности. Исходным материалом для создания таких сортов может служить коллекция образцов нута, собранная из различных эколого-климатических зон (Balashov et al., 2003; Vishnyakova, 2015). В связи с этим, актуально комплексное изучение коллекционных образцов нута и выделение источников хозяйственно ценных призна- ков с целью создания новых сортов пригодных для возделывания в условиях южной лесостепи Западной Сибири.

\section{Материалы и методы}

Исследования проводили в Ечебноопытном хозяйстве Омского ГАУ с 2012 по 2016 гг. в южной лесостепи Западной Сибири. Южная лесостепь характеризуется теплым, умеренно увлажненным климатом. Сумма средних суточных температур за период с температурой выше $10^{\circ} \mathrm{C}$ составляет в среднем 100-130 дней. Безморозный период в этом районе в среднем составляет 110-120 дней, период с температурой выше $0^{\circ} \mathrm{C}-185$, выше $5^{\circ} \mathrm{C}-157$, выше $10^{\circ} \mathrm{C}-123$ дня. Отрицательные ночные температуры весной прекращаются 21, 22 мая и появляются осенью $10-22$ сентября. Обилие солнца и тепла в значительной мере компенсирует кратковременность безморозного периода и обеспечивает вегетацию растений. Южная лесостепь Омской области относится к зоне неустойчивого увлажнения. Средняя многолетняя годовая сумма осадков составляет 300-350 мм, за период с устойчивой среднесуточной температурой воздуха выше $10^{\circ} \mathrm{C}$ осадков выпадает 190 220 мм. Обеспеченность растений влагой в районе характеризуется гидротермическим коэффициентом 1,0-1,2, который указывает на удовлетворительную в среднем влагообеспеченность в период активной вегетации. Почва поля - чернозем обыкновенный среднемощный, среднегумусный.

Объектом исследований служили 23 коллекционных образца ВИР, полученных из Всероссийского института генетических ресурсов растений имени Н. И. Вавилова (ВИР, г. Санкт-Петербург) и 23 образца коллекции сомаклонов (Сибирский НИИ кормов, г. Новосибирск). В качестве стандарта использовали районированный сорт 'Краснокутский 123'. Посев проводили в четырехкратной повторности на глубину 5 см. Количество семян в каждом повторении 30 шт. Наблюдения, учеты и анализы проводили согласно «Методическим указаниям по изучению коллекции зерновых бобовых культур» (Korsakov et al., 1975). Жизнеспособность пыльцевых зерен нута определяли по «Методическим указаниям по гаметной селекции сельскохозяйственных растений (методология, результаты и перспективы)» (Balashova et al., 2001). Иерархический кластерный анализ проведен в модуле 
Hierarchical Claster Analysis статистического пакета SPSS for Windows 13 (Byuyul, 2002). Расчет степени доминирования проведен по методике G. M. Beil, R. E. Atkins (1965).

\section{Результаты и обсуждение}

Средиземноморское происхождение нута, его дальнейшее распространение по странам земного шара, способствовало формированию большого разнообразия сортов по продолжительности вегетационного периода.

Продолжительность вегетационного периода и его структура определяют пригодность сорта к условиям зоны выращивания. Оптимальная его продолжительность позволяет сорту наилучшим образом использовать почвенно-климатические ресурсы зоны и в максимальной степени избегать отрицательного влияния неблагоприятных условий. С вегетационным периодом связаны многие хозяйственно-биологические признаки и свойства (устойчивость к засухе, болезням и вредителям, качество зерна и др.). В условиях короткого безморозного периода, которым характеризуется Омская область, селекция должна быть направлена на сокращение вегетационного периода. За время исследований продолжительность вегетационного периода коллекционных образцов варьировала от 71 до 124 дней.

За время наших исследований самый короткий вегетационный период имели коллекционные образцы: C4-Deemin, C7Александрит, С14-Александрит, С15Волгоградский 10, ILC-10005, C-82, C-83, 'Волгоградский 10' (табл. 1).

Таблица 1. Продолжительность вегетационного и межфазных периодов выделившихся образцов нута (2012-2016 гг.)

Table 1. Duration of the growing season and interphase periods for the identified chickpea accessions (2012-2016)

\begin{tabular}{|c|c|c|c|c|c|}
\hline $\begin{array}{l}\text { № } \\
\Pi / \Pi\end{array}$ & Образец & $\begin{array}{l}\text { Посев- } \\
\text { всходы }\end{array}$ & $\begin{array}{l}\text { Всходы- } \\
\text { цветение }\end{array}$ & $\begin{array}{l}\text { Цветение- } \\
\text { созревание }\end{array}$ & $\begin{array}{c}\text { Вегетационный } \\
\text { период }\end{array}$ \\
\hline 1 & $\begin{array}{l}\text { Краснокутский 123, стан- } \\
\text { дарт }\end{array}$ & 10 & 33 & 54 & 91 \\
\hline \multicolumn{6}{|c|}{ Коллекция ВИР } \\
\hline 2 & C-17, к-3833 & 17 & 29 & 51 & 97 \\
\hline 3 & ILC-10005 & 15 & 30 & 51 & 92 \\
\hline 4 & $\mathrm{C}-18$ & 13 & 32 & 59 & 97 \\
\hline 5 & $\mathrm{C}-82$ & 13 & 32 & 60 & 97 \\
\hline 6 & $\mathrm{C}-83$ & 10 & 34 & 61 & 96 \\
\hline \multicolumn{6}{|c|}{ Коллекция сомаклонов СибНИИ кормов } \\
\hline 7 & C4-Deemin & 10 & 31 & 51 & 86 \\
\hline 8 & С7-Александрит & 10 & 31 & 51 & 86 \\
\hline 9 & С14-Александрит & 10 & 31 & 51 & 86 \\
\hline 10 & С15-Волгоградский 10 & 10 & 30 & 53 & 87 \\
\hline 11 & C17-C11 & 10 & 31 & 51 & 86 \\
\hline
\end{tabular}

Нут в отличие от других бобовых в меньшей степени поражается болезнями и вредителями. При визуальной оценке посевов коллекции нута за годы изучения обнаружено слабое повреждение растений нутовым минером в фазу бутонизации и поражение аскохитозом отдельных образцов до 5\%. Компактная форма куста и высота прикрепления нижнего боба являются важными селекционными при- знаками, характеризующими пригодность сортов нута к механизированному возделыванию. Форма куста у большинства образцов была компактной, исключение составил образец ILC10005 со стелющейся формой куста. Высота прикрепления нижнего боба коллекционных образцов варьировалась от 8 до 32 см. Наибольшую высоту при- 
крепления нижнего боба имели образ- лились коллекционные образцы: С-83, цы: C-18, ILC-248. Высота растений за C18-Краснокутский 123, C9-A-11, C11годы испытания изменялась от 39,7 до Юбилейный (табл.2).

150,0 см; по данному показателю выде-

Таблица 2. Биометрические показатели

выделившихся образцов нута (2012-2016 гг.)

Table 2. Biometric parameters of the identified chickpea accessions (2012-2016)

\begin{tabular}{c|l|c|c|c|c}
\hline $\begin{array}{c}\text { № } \\
\text { п/п }\end{array}$ & $\begin{array}{c}\text { Оуразец } \\
\text { растения, г }\end{array}$ & $\begin{array}{c}\text { Высота } \\
\text { растения, } \\
\text { см. }\end{array}$ & $\begin{array}{c}\text { Высота } \\
\text { прикрепления } \\
\text { нижнего боба, см. }\end{array}$ & $\begin{array}{c}\text { Число ветвей } \\
\text { первого } \\
\text { порядка, шт. }\end{array}$ \\
\hline & $\begin{array}{l}\text { Краснокутский 123, } \\
\text { стандарт }\end{array}$ & 71,8 & 80,5 & 30,6 & 2,8 \\
\hline \multicolumn{5}{|c|}{ Коллекция ВИР } \\
\hline 2 & ILC-2394 & 86,6 & 80,3 & 28,4 & 2,9 \\
\hline 3 & ILC-2402 & 66,9 & 89,6 & 27,5 & 2,1 \\
\hline 4 & ILC-482 & 89,5 & 86,1 & 29,1 & 2,5 \\
\hline 5 & С-18 & 93,9 & 86,1 & 29,7 & 2,7 \\
\hline 6 & С-35 & 73,8 & 80,3 & 28,1 & 2,1 \\
\hline 7 & С-83 & 79,5 & 92,8 & 28,4 & 2,9 \\
\hline \multicolumn{7}{|c|}{ Коллекция сомаклонов СибНИИ кормов } \\
\hline 8 & С9-А-11 & 61,6 & 94,8 & 38,0 & 2,4 \\
\hline 9 & С10-Колорит & 60,7 & 90,8 & 34,5 & 2,8 \\
\hline 10 & С11-Юбилейный & 69,2 & 93,2 & 38,2 & 2,8 \\
\hline 11 & С14-Александрит & 68,3 & 83,8 & 31,9 & 3,2 \\
\hline 12 & С18-Краснокутский 123 & 67,9 & 95,9 & 39,7 & 2,9 \\
\hline 13 & С19-1-10 & 69,5 & 92,9 & 34,8 & 2,8 \\
\hline 14 & С20-3-10 & 60,2 & 92,6 & 34,4 & 2,7 \\
\hline 15 & С21-Ғ-11 & 57,7 & 83,3 & 32,3 & 2,8 \\
\hline 16 & С23-Колорит & 56,3 & 91,5 & 36,3 & 2,5 \\
\hline & & 7,3 & 7,7 & 2,5 & 0,2 \\
\hline
\end{tabular}

Урожайность нута и ее элементы за годы испытаний в условиях южной лесостепи Западной Сибири значительно варьировались в зависимости от погодных условий (табл. 3).

Наибольшую выраженностью изученных признаков имели образцы: по числу семян с растения - ILC-2394, ILC-482, C-82, 'Волгоградский 10', ILC-2402; по массе семян с растения - ILC-2394, ILC-10005, ILC3407, ILC-482; по числу бобов с растения C-243, C-18, C-17; по массе бобов с растения - С-243, С-18, С-17, С-303.

Химический анализ зерна выделившихся коллекционных образцов нута показал высокое содержание белка - до 21,5\%, цинка - до 39 мг/кг, йода - до 0,06 мг/кг.
Нут имеет важное агротехническое значение как восстановитель и улучшитель почвы. В симбиозе с азотфиксирующими бактериями нут усваивает большое количество атмосферного азота, использует малодоступные для зерновых культур труднорастворимые минеральные соединения. Результаты изучения способности нута к образованию азотфиксирующих клубеньков на корнях в условиях южной лесостепи Западной Сибири позволили выявить образцы с большим количеством крупных клубеньков (более 1 мм), сохраняющих высокую активность до конца вегетации растений: С2-Краснокутский 123, С8-Александрит, С5-Краснокутский 123 и С-82. Число клубеньков у выделившихся коллекционных образцов варьировалось от 30 до 74 шт. 
Таблица 3. Элементы продуктивности

выделившихся образцов нута (2012-2016 гг.)

Table 3. Productivity components in the identified chickpea accessions (2012-2016)

\begin{tabular}{|c|c|c|c|c|c|}
\hline $\begin{array}{c}\text { № } \\
\text { П/ா }\end{array}$ & Образец & $\begin{array}{c}\text { Число } \\
\text { бобов с } \\
\text { растения, } \\
\text { шт. }\end{array}$ & $\begin{array}{c}\text { Масса } \\
\text { бобов с } \\
\text { растения, } \\
\Gamma\end{array}$ & $\begin{array}{c}\text { Число } \\
\text { семян с } \\
\text { растения, } \\
\text { шт. }\end{array}$ & $\begin{array}{c}\text { Масса } \\
\text { семян с } \\
\text { растения, } \\
\Gamma\end{array}$ \\
\hline 1 & $\begin{array}{l}\text { Краснокутский 123, } \\
\text { стандарт }\end{array}$ & 87,2 & 34,1 & 100,6 & 26,4 \\
\hline \multicolumn{6}{|c|}{ Коллекция ВИР } \\
\hline 2 & С-27, к-3827 & 81,8 & 23,2 & 73,2 & 17,6 \\
\hline 3 & С-243, к-3830 & 104,4 & 35,9 & 84,7 & 22,7 \\
\hline 4 & С-303, к-3832 & 84,9 & 30,7 & 78,6 & 19,2 \\
\hline 5 & 22-Б, 3840 & 72,3 & 27,4 & 53,7 & 16,4 \\
\hline 6 & C-17, к-3833 & 93,9 & 31,0 & 85,6 & 16,5 \\
\hline 7 & $\mathrm{C}-18$ & 116,9 & 30,1 & 85,4 & 15,8 \\
\hline \multicolumn{6}{|c|}{ Коллекция сомаклонов СибНИИ кормов } \\
\hline 8 & С1-Александрит & 97,9 & 38,3 & 120,7 & 26,9 \\
\hline 9 & С3-Александрит & 67,0 & 25,9 & 75,3 & 20,5 \\
\hline 10 & C4-Deemin & 66,3 & 32,9 & 71,1 & 25,3 \\
\hline 11 & С6-Александрит & 70,8 & 30,1 & 72,6 & 22,3 \\
\hline 12 & С7-Александрит & 88,9 & 34,0 & 96,1 & 24,2 \\
\hline 13 & C13-Deemin & 71,7 & 25,7 & 74,3 & 20,2 \\
\hline 14 & С14-Александрит & 71,3 & 26,7 & 82,8 & 21,1 \\
\hline 15 & C19-1-10 & 75,5 & 26,5 & 80,2 & 20,2 \\
\hline \multicolumn{2}{|r|}{$H C P_{05}$} & 9,5 & 2,9 & 8,1 & 1,9 \\
\hline
\end{tabular}

Методы многомерной статистики позволяют селекционеру проводить объективную комплексную оценку исходного материала. В настоящее время для разделения исходного множества объектов на группы широко используют кластерный анализ, путем попарного сравнивания по выбранным критериям.

Использование кластерного анализа по семи основным хозяйственно ценным признакам позволило нам выявить три хорошо различимых кластера (рисунок).

Для образцов, выделенных в кластеры, характерен схожий набор признаков внутри кластера и достоверные различия с другими кластерами. Первый кластер объединил 7 образцов, сочетающих укороченную продолжительность вегетационного периода (99 дней), высокое прикрепление нижнего боба (22 см.), небольшое количество бобов на растении (36 шт.) и массу семян с одного растения (2,6 г). Во второй кластер вошли 6 коллекционных образцов, растения которых сочетают максимальное количество бобов на растении (95 шт.), высокое количество семян с одного растения (71 шт.) и высокое прикрепление нижнего боба $(30,1$ см).

В третий кластер вошли 10 образцов, которые имеют продолжительный вегетационный период (101 день), среднее количество бобов (65 шт.) и число семян с растения (60 шт.).

При создании новых сортов в качестве исходного материала необходимо уделять большое внимание растениям, относящимся ко второму кластеру. К нему отнесены растениями с комплексом ценных признаков, отбор которых наиболее важен для селекции нута на высокую продуктивность и пригодность к механизированной уборке. 


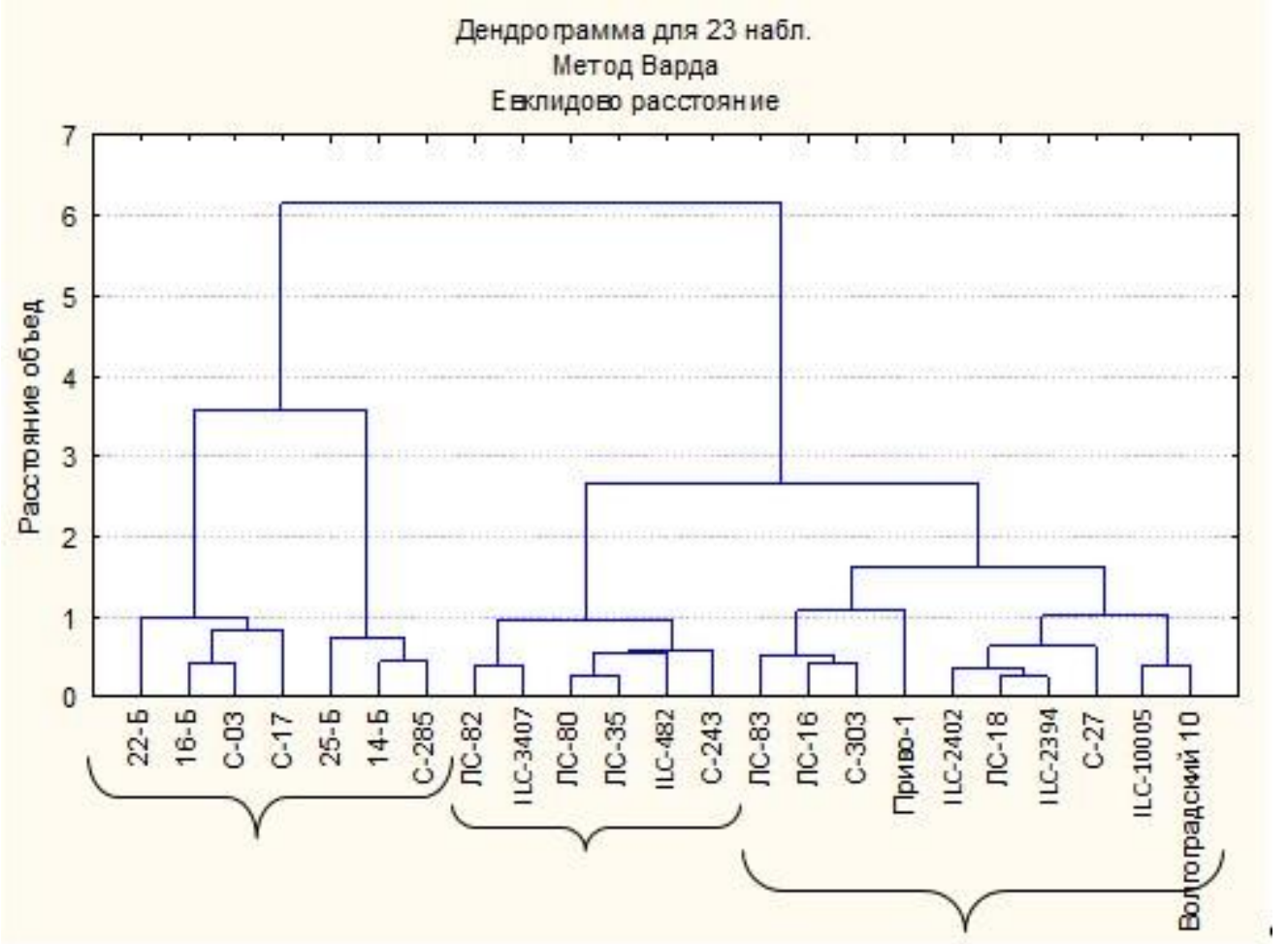

\section{Рисунок. Дендрограмма кластеризации образцов нута коллекции ВИР по основным хозяйственно ценным признакам \\ Figure. Clustering dendrogram for the chickpea accessions from VIR according to major agronomic characters}

Изучение корреляционной зависимости между продуктивностью растений нута и основными хозяйственно ценными признаками в условиях Омской области выявило наличие сильной положительной связи с числом семян $(\mathrm{r}=0,85)$, массой бобов с растения $(\mathrm{r}=0,98)$ и числом бобов на растении $(\mathrm{r}=0,79)$; с высотой прикрепления нижнего боба связь в зависимости от погодных условий варьировалась от средней отрицательной в засушливых условиях $(\mathrm{r}=-0,61)$ до слабой положительной в условиях переувлажнения $(\mathrm{r}=0,19)$. Таким образом, ведущая роль в определении продуктивности растений у изученных образцов нута в условиях Омской области принадлежит числу семян, массе и числу бобов на растении. Образцы, выделившиеся по комплексу ценных признаков, были включены нами в гибридизацию. Завязываемость гибридных семян была невысокая и составила в благоприятные годы в среднем $16 \%$. Успех полевой гибридизации в наших условиях сильно зависит от погодных усло- вий во время цветения нута. В годы с высокой влажностью воздуха и невысокой температурой завязываемость семян была низкой. Лабораторный анализ пыльцевых зерен нута при такой погоде выявил их нежизнеспособность, отсутствие образования пыльцевых трубок и, следовательно, нецелесообразность проведения полевой гибридизации растений.

Изучение характера наследования хозяйственно ценных признаков у гибридов нута показало, что положительное сверхдоминирование (гетерозис) наблюдается по массе и числу бобов с растения, массе и числу семян с растения; отрицательное сверхдоминирование (депрессия) - по высоте прикрепления нижнего боба; промежуточное наследование признака - по высоте растений и продолжительности вегетационного периода (табл. 4). По признакам, наследуемым по типу гетерозиса, высока эффективность отбора ценных генотипов. Отбор следует вести в поздних поколениях гибридов. 
Таблица 4. Наследование хозяйственно ценных признаков у гибридных популяций $F_{1}$ нута

Table 4. Inheritance of agronomic traits in $F_{1}$ hybrid populations of chickpea

\begin{tabular}{l|c|c}
\hline Признак & $\mathrm{hp}$ & Тип наследования \\
\hline $\begin{array}{l}\text { Продолжительность вегетационно- } \\
\text { го периода }\end{array}$ & 0,6 & Промежуточное наследование \\
\hline Высота растений & 0,8 & Промежуточное наследование \\
\hline Высота прикрепления нижнего боба & $-2,4$ & Отрицательное сверхдоминирование \\
\hline Число бобов с одного растения & 17,9 & Положительное сверхдоминирование \\
\hline Масса бобов с одного растения & 12,26 & Положительное сверхдоминирование \\
\hline Число семян с одного растения & 11,75 & Положительное сверхдоминирование \\
\hline Масса семян с одного растения & 11,11 & Положительное сверхдоминирование \\
\hline
\end{tabular}

\section{Выводы}

1. Результаты изучения коллекции нута свидетельствуют о перспективности возделывания культуры в условиях южной лесостепи Западной Сибири, а также высокой значимости коллекций растений для создания исходного материала.

2. В качестве источников отдельных хозяйственно ценных признаков нута в селекции для условий южной лесостепи Западной Сибири следует использовать коллекционные образцы:

на сокращение вегетационного периода: C4-Deemin, C7-Александрит, C14Александрит, C15-Волгоградский 10, ILC10005 , С-82, С-83, 'Волгоградский 10';

на уменьшение высоты растения: ILC10005, ‘Волгоградский 10', C4-Deemin;

на увеличение числа семян с одного растения: ILC-2394, ILC-482, C-82, 'Волгоградский 10', ILC-2402;

на увеличение массы семян с одного растения: ILC-2394, ILC-10005, ILC-3407, ILC-482;

на увеличение числа бобов с одного растения: C-243, C-18, C-17;

на увеличение массы бобов с одного растения: C-243, C-18, C-17, C-303

3. Образцы нута в условиях южной лесостепи Западной Сибири имеют слабое поражение аскохитозом и нутовой мухой.

4. По технологичности и приспособленности к механизированной уборке большинство образцов коллекции нута соответствуют требованиям.
5. Высокую симбиотическую активность в условиях южной лесостепи Западной Сибири имеют образцы С2-Краснокутский 123, С-8Александрит, С5-Краснокутский 123 и С-82.

6. Использование кластерного анализа в селекции позволяет уменьшить объем прорабатываемого материала на начальных этапах селекционного процесса, а также более целенаправленно и эффективно проводить отборы в расщепляющихся гибридных популяциях. Практическую значимость в качестве исходного материала при создании новых сортов нута имеют образцы, относящиеся ко второму кластеру.

7. Селекцию на повышение урожайности нута в условиях южной лесостепи Западной Сибири следует вести по числу семян, массе и числу бобов с растения.

8. Выявлен характер наследования основных хозяйственно ценных признаков:

положительное сверхдоминирование (гетерозис) наблюдается по массе и числу бобов с растения, массе и числу семян с растения;

отрицательное сверхдоминирование (депрессия) - по высоте прикрепления нижнего боба;

промежуточное наследование - по высоте растений и продолжительности вегетационного периода.

9. По признакам, наследуемым по типу гетерозиса (по массе и числу бобов с растения, массе и числу семян с растения), высока эффективность отбора хозяйственно ценных признаков. 


\section{References/Литература}

Balashov V. V., Tyutyuma N. V. Technology of chickpea Volga-Don province (Tehnologija proizvodstva nuta Volgo-Donskoj provincii) // Vidovoe raznoobrazie i dinamika razvitija prirodnyh proizvodstvennyh kompleksov Nizhnej Volgi - Species diversity and the dynamics of the natural production complexes of the Lower Volga, 2003, vol. 1, pp. 499-516 [in Russian] (Балашов В. В., Тютюма Н. В. Технология производства нута Волго-Донской провинции // Видовое разнообразие и динамика развития природных производственных комплексов Нижней Волги. 2003. Т. 1. С. 499-516).

Balashova N. N., Kozar E. G. Guidelines on gamete selection of agricultural plants (methodology, results and prospects) (Metodicheskie ukazanija po gametnoj selekcii sel'skohozjajstvennyh rastenij (metodologija, rezul'taty i perspektivy), Moscow: VNIISSOK, 2001, 386 p. [in Russian] (Балашова Н. Н., Козарь Е. Г. Методические указания по гаметной селекции сельскохозяйственных растений (методология, результаты и перспективы). М.: ВНИИССОК. 2001. 386 c.).

Beil G. M. Atkins R. E. Inheritance of quantitative characters in grain sorghum // Jowa J Sci. 965, vol. 39, no. 3, pp. 345-348.

Bulyncev $S$. V. World collection chickpeas and prospects for its use (Mirovaja kollekcija nuta i perspektivy ee ispol'zovanija). Materialy 5 Mezhdunarodnogo Simpoziuma «Novye i netradicionnye rastenija i perspektivy ih ispol'zovanija»-Proceedings of the International Symposium 5 "New and nonconventional plants and prospects of their use", Moscow, 2003, vol. 2, pp. 19-21 [in Russian] (Бульнцеев C.B. Мировая коллекция нута и перспективы ее использования // Материалы 5 Международного Симпозиума «Новые и нетрадиционные растения и перспективы их использования». М., 2003. Т. 2. С. 19-21).

Byuyul A. SPSS: data processing art. Analysis of statistical data and restore hidden patterns (SPSS: iskusstvo obrabotki informacii. Analiz statisticheskih dannyh i vosstanovlenie skrytyh zakonomernostej). SPb.: DiaSoftYuP, 2002. 608 p. [in Russian] (Бююль A. SPSS: искусство обработки информации. Анализ статистических данных и восстановление скрытых закономерностей. СПб.: ДиаСофтЮП, 2002. 608 c.).

Germanceva N. I. Chickpea breeding in the conditions of dry steppe zone of the Volga region // Proceedings of Applied Botany, Genetics and Breeding, 2014, vol 175, iss 3, pp. 66-83 [in Russian] (Германцева Н. И. Селекция нута в условиях сухостепной зоны Поволжья // Тр. по прик. бот., ген. и сел. 2014. Т. 175. Вып. 3, C. 66-83).
Kazydub N. G., Kuz'mina S. P., Dem'janenko K. A. Cultivar collection of chickpea in the southern forest-steppe of Western Siberia (Sortoizuchenie kollekcii nuta $\mathrm{v}$ juzhnoj lesostepi Zapadnoj Sibiri) // Sovremennye problemy nauki i obrazovanija - Modern problems of science and education, 2015. no. 1-1, p. 1658 [in Russian] (Казыдуб Н. Г., Кузьмина С. П., Демьяненко K. A. Сортоизучение коллекции нута в южной лесостепи Западной Сибири // Современные проблемы науки и образования. 2015. № 1-1. С. 1658).

Kazydub N. G., Kuz'mina S. P., Korobejnikova M. $M$. Results of participation of the Omsk State University of Agriculture in the implementation of the state program of import substitution (Rezul'taty uchastija Omskogo GAU v realizacii gosudarstvennoj programmy importozameshhenija) // Trudy Kubanskogo gosudarstvennogo agrarnogo universiteta - Proceedings of the Kuban State Agrarian University, 2016, no. 2 (59). pp.162-167 [in Russian] (Казыдуб Н. Г., Кузьмина С. П., Коробейникова М. М. Результаты участия Омского ГАУ в реализации государственной программы импортозамещения // Труды Кубанского государственного аграрного университета. 2016. № 2 (59). C. 162-167).

Korsakov N. I., Adamova O. A., Budakova V. I. et all. Guidelines for the study of the collection of grain legumes (Metodicheskie ukazanija po izucheniju kollekcii zernovyh bobovyh kul'tur). Leningrad: RIP, 1975, 59 p. [in Russian] (Kopсаков Н. И., Адамова О. А., Будакова В. И.и др. Методические указания по изучению коллекции зерновых бобовых культур. Л.: ВИР, 1975. 59 с.).

Kuz'mina S. P., Kazydub N. G., Burlakov A. A. Results of the study collection of chickpea accessions for breeding purposes in the Omsk State Agrarian University (Rezul'taty izuchenija sortoobrazcov kollekcii nuta dlja selekcionnyh celej v Omskom GAU). Zernobobovye kul'tury - razvivajushheesja napravlenie v Rossii pervyj mezhdunarodnyj forum - Developing direction of the first international forum in Russia, 2016. pp. 79-83 [in Russian] (Кузьмина С. П., Казыдуб Н. Г., Бурлаков А. А. Результаты изучения сортообразцов коллекции нута для селекционных целей в Омском ГАУ // Зернобобовые культуры - развивающееся направление в России. 2016. С. 79-83).

Rozhanskaja $O$. A. Somaclonal variation of plants as a source of reproduction of the species biodiversity (Somaklonal'naja izmenchivost' rastenij kak istochnik vosproizvodstva vidovogo bioraznoobrazija). Problema i strategija sohranenija bioraznoobrazija rastitel'nogo mira Severnoj Azii: Mater. Mezhdunarodnoj konferencii - Issue and Biodiversity Strategy flora of Northern Asia: Materials of the International Conference, 
Novosibirsk, 2009, pp. 207-209 [in Russian] (Рожанская O. А. Сомаклональная изменчивость растений как источник воспроизводства видового биоразнообразия // Проблема и стратегия сохранения биоразнообразия растительного мира Северной Азии: Матер. Международной конференции. Новосибирск, 2009. С. 207-209.)

Rozhanskaja O. A. Soybeans and chickpeas in Siberia: tissue culture, somaclones mutants (Soja i nut v Sibiri: kul'tura tkanej, somaklony, mutanty), Novosibirsk, 2005, 155 p. [in Russian] (Рожанская О. А. Соя и нут в Сибири: культура тканей, сомаклоны, мутанты. Новосибирск, 2005. 155 с.).

Vishnjakova M. A., Bulyncev S. V., Burljaeva $M$. O., Buravceva T. V., Egorova G. P., Semenova E. V., Seferova I. V. Starting material breeding vegetable legumes collection RIP (Ishodnyj material dlja selekcii ovoshhnyh zernobobovyh kul'tur v kollekcii VIR). Ovoshhi Rossii - Vegetables Russia, 2013, no. 1 (18), pp. 1-26 [in
Russian] (Вишнякова М. А., Бульнцев С. В. Бурляева М. О., Буравцеева Т. В., Егорова Г. П., Семенова Е. В., Сеферова И. В. Исходный материал для селекции овощных зернобобовых культур в коллекции ВИР // Овощи России. 2013. № 1 (18). С. 16-26).

Vishnyakova M. A. The ways of the effective use of plant genetic resources in the creation of competitive domestic varieties of grain legumes (Puti jeffektivnogo ispol'zovanija geneticheskih resursov rastenij $\mathrm{v}$ sozdanii konkurentosposobnyh otechestvennyh sortov zernobobovyh kul'tur). Trudy Kubanskogo GAU - Proceedings of the Kuban State Agrarian University, 2015, no. 3 (54), pp. 111-117 [in Russian] (Вишнякова М. А. Пути эффективного использования генетических ресурсов растений в создании конкурентоспособных отечественных сортов зернобобовых культур // Труды Кубанского ГАУ. 2015. Вып. 3 (54). C. 111-117). 
DOI: 10.30901/2227-8834-2017-1-58-67

\section{Б. Лапински ${ }^{1}$}

А. Рачвалска ${ }^{2}$

${ }^{1}$ Национальный центр по генетическим ресурсам растений, Институт селекции и акклиматизации растений (ИСАР) - Национальный исследовательский институт, Радзиков, Польша,

${ }^{2}$ Институт селекции и акклиматизации растений (ИСАР) Экспериментальная станция в Гродковице,

Польша,

e-mail: b.lapinski@ihar.edu.pl

\section{Ключевые слова:}

аллоплоид, Avena macrostachya, Avena sativa, скрещивание, зимостойкость, зимующий овес, урожай

Поступление: 27.12.2016

\section{Принято:}

06.12 .2016

\section{ИСПОЛЬЗОВАНИЕ AVENA MACROSTACHYА ДЛЯ УЛУЧШЕНИЯ ЗИМОСТОЙКОСТИ ОВСА В ПОЛЬШЕ}

Актуальность. Эксперименты с возделыванием сортов зимующего овса в Польше в конце XX века, особенно в засушливые годы, показали увеличение потенциала урожайности иностранных в два раза по сравнению с местными стандартными яровыми сортами овса. Тем не менее, в этом случае мягкие зимы были залогом успеха таких сортов, т. к. их зимостойкость была достаточной при данных погодных условиях. Польская же программа по улучшению зимостойкости овса началась только в 2002 г. Материалы и методы. Иностранные зимующие сорта и линии овса были скрещены с выделенными образцами тетраплоидного многолетнего дикого вида Avena macrostachya Bal. ex Coss et Dur. Гибриды $\mathrm{F}_{1}$ были клонированы, обработаны колхицином и выращены вместе с зимующими сортами овса, которые являлись спонтанными опылителями для данных гибридов. Результаты и обсуждение. Были получены три гибрида, из которых по двум были получены семена. Большие различия были замечены в уровне фертильности и структуре хромосом в потомстве двух гибридов. Следующее поколение $\left(\mathrm{B}_{1} \mathrm{~F}_{1}\right.$ или $\left.\mathrm{F}_{2}\right)$ состояло из растений с числом хромосом от 40 до 49 , октоплоидов $(2 n=56)$ и растений, несущих в своем генотипе от 60 до 70 хромосом. Растения из первой группы мнимых гексаплоидов, как правило, обладали мужской стерильностью, но после дополнительного бекроссирования пыльцой A. sativa L. они становились фертильными. В засушливые годы 2009 и 2013 гг. они имели почти на $100 \%$ выше урожайность, чем стандартные яровые сорта овса. Натура зерна зимующего овса была также на 4 кг/л выше, чем у ярового овса. Две выделенные пленчатые линии показали уровень зимостойкости лучше, чем родительская популяция A. sativa, находящаяся в Польском государственном сортоиспытании. Эти линии могут быть рекомендованы для возделывания в регионах с устойчивым снежным покровом, потому что растения этих линий погибали в бесснежные зимы при температуре поверхности почвы ниже $-14^{\circ} \mathrm{C}$, такие зимы были дважды в течение последних 8 лет в районе г. Радзикова. Погодные условия прошлой зимы (2015/2016 гг.) были особенно экстремальными, даже для линий октоплоидов, которые ранее считались наиболее зимостойкими. Октоплоиды не болеют, формируют большое количество зеленой массы и очень крупное зерно, богатое белком, однако их зерновая продуктивность не велика (в настоящее время она составляет только 50-67\% от урожайности лучших зимующих сортов овса) и вегетационный период удлинен. Последний суровый зимний сезон был полезным для отбора нескольких новых гексаплоидных линий из комбинаций скрещиваний $6 x \times 8 x$, которые были сделаны для трансгрессии морозоустойчивости от октоплоидного родителя. Аллоплоиды sativa-macrostachya с уровнем плоидности $8 \mathrm{x}$ или 10x оказались эффективными источниками зимостойкости для гексаплоидного овса. 
B. Lapinski ${ }^{1}$,

A. Rachwalska ${ }^{2}$

${ }^{1}$ National Centre for Plant Genetic Resources, Plant Breeding and Acclimatization Institute (IHAR)- National Research Institute- Radzików, Poland,

${ }^{2}$ Plant Breeding and

Acclimatization Institute (IHAR)

Experiment Station Grodkowice, Poland. PL-05-870 BŁONIE, Radzików - IHAR, KCRZG, e-mail: b.lapinski@ihar.edu.pl

Key words:

alloploidy, Avena macrostachya, Avena sativa, wide cross, winterhardiness, winter oat, yield

Received:

27.12.2016

Accepted:

06.03.2017

\section{USING AVENA MACROSTACHYA FOR IMPROVEMENT OF OAT WINTERHARDINESS IN POLAND}

Background: The experiments with winter oat cultivation in Poland at the end of $20^{\text {th }}$ century indicated potential of high yielding, especially in dry seasons, when foreign winter strains or cultivars doubled yields of local spring standards. However, a mild preceding winter season was condition for the success; winterhardiness of foreign oats was sufficient only in some years. The Polish program of winterhardiness improvement in oat began in 2002. Materials and methods: Foreign winter oat cultivars and lines were crossed with accessions of tetraploid perennial wild species Avena macrostachya Bal. ex Coss et Dur. The $F_{1}$ hybrids were intensely cloned, treated with colchicine and grown in vicinity of winter oat pollinators. Results and conclusions: Three $F_{1}$ hybrids were obtained, two of them set seed. Large differences were noticed in fertility level and chromosome constitution of progeny of the two hybrids. The next generation $\left(\mathrm{B}_{1} \mathrm{~F}_{1}\right.$ or $\left.\mathrm{F}_{2}\right)$ consisted of plants with chromosome numbers between 40 and 49 , octoploids $(2 n=56)$ and plants carrying 60 to 70 chromosomes. The quasi-hexaploids of the first group were generally male sterile, but after additional back-cross to A. sativa L. valuable hexaploid breeding strains were produced. In the dry seasons 2009 and 2013 they yielded nearly 100\% higher than the spring cultivar standard. Test weight of the winter oat was also ca. $4 \mathrm{~kg} / \mathrm{hl}$ higher than in the spring oat. Two of the husked strains, showing winterhardiness level better than the starting A. sativa population, are in the Polish state variety trials. They could be recommended for the regions with stable snow cover, because they were not able to survive naked ground surface temperatures below $-14^{\circ} \mathrm{C}$, which happened twice in Radzików in the last 8 years. Especially the last winter (2015/2016) was destructive, even for the octoploids, which were earlier considered the most winter-hardy oats. The octoploids produce healthy green mass and very large plump grain, rich in protein, however they require a breeding effort to increase yield (now 50-67\% of the best winter hexaploids) and to make ripening uniform. The last severe winter season was helpful for selection of several new hexaploid strains from the $6 \mathrm{x} x 8 \mathrm{x}$ cross combinations, which were transgressive in frost resistance to their octoploid parents. The $8 \mathrm{x}$ or $10 \mathrm{x}$ sativa-macrostachya alloploids proved to be effective sources of winterhardiness for hexaploid oat. 


\section{Introduction}

Preliminary experiments with winter oat in Poland at the end of the 20 century indicated its potential of high yielding especially in dry seasons, when foreign winter strains or cultivars doubled yields of local spring standards (Zygmynt Nita, personal comm.). However, a mild preceding winter season was condition for the success; winterhardiness of the oat lines from western countries was generally insufficient.

A stagnation was recorded in oat winterhardiness in the second half of the last century until a progress was reported in North Carolina, USA, first as a result of crossing the winterhardy cultivars 'Wintok' and 'Norline' (Livingston, Elwinger, 1995; Livingston et al., 2004), and later after application of the wild species Avena macrostachya Bal. ex Coss et Dur. as a cross component to the cultivar Brooks (Santos et al., 2002). A cross with an alien species may introduce new and useful genetic variation when intraspecific variation of a crop is insufficient; there is also possible advantage of whole genome incorporation through alloploidy. It is relevant particularly for the quantitative traits including abiotic stress responses. Wide crossing of Avena sativa L. with A. macrostachya was the starting point for winter oat acclimation in Poland. Initiation of the work in IHAR-Radzików was encouraged by the acceptable level of winter survival in the Uniform Oat Winter Hardiness Nursery (UOWHN) grown in the location since 1993 , as well as by presence of a relatively large A. macrostachya collection in the IHAR gene bank. The accessions were collected during expedition in the Atlas mountains elevated sites, next sown in Gubałówka, Poland, on foothills of the Tatra mountains, where clones of this perennial species survived nearly 10 years. Attractiveness of the variation source was strengthened by high resistance of A. macrostachya to biotic stresses. Herrmann (2006) reported introgression of powdery mildew resistance to A. sativa. Loskutov (2007) listed other resistances potentially useful for breeders: to crown and stem rust, septoria blotch, helminthosporium blotch, myrothecium blotch, frit fly; Weibull (1988) announced resistance to aphid Rhopalosiphum padi L.

\section{Breaking the interspecific isolation barriers}

The crossing between foreign winter oats and A. macrostachya was performed in
Radzików in 2002. Single hybrid seeds were obtained only in three of 51 cross combinations, when common oat was used as a mother plant. Only two of the $F_{1}$ plants recovered (after in vitro embryo culture) were sufficiently vigorous and produced abundantly tillers in greenhouse, which enabled establishment of large clonal populations. The clones were treated with colchicine and planted in field in early spring, among a winter and spring sown mixture of winter oats, which were the additional pollen donors for the $F_{1}$ plants. The clone derived from the cross involving winterhardy oat cv. 'Wintok' (W-F $)$ consisted of finally 969 plants and produced ca. 2050 panicles and 3 germinable seeds. The other clone of 2073 plants based on a German (LochowPetkus) non-winterhardy 'Mirabel/Pendragon' recombinant line $\left(\mathrm{MP}-\mathrm{F}_{1}\right)$, produced ca. 9890 panicles and 54 germinable seeds. The earlier publications of Lapinski et al. $(2012,2013)$ contain more detailed description of overcoming the interspecific reproductive barriers.

The results strongly confirmed the idea of starting from a broad variety of genotypes in a difficult interspecific cross. In addition to the known and expected differences in crossability, $F_{1}$ viability and sterility, a substantial difference occurred in toleration of aneuploidy between the successful W- and MP- cross combinations, which greatly determined the direction of further evolution of the progenies. The $F_{1}$ generation had 35-chromosomes, 21 from $A$. sativa mother and 14 from $A$. macrostachya (autotetraploid, $4 \mathrm{n}=28$ ). Progeny of the W-F 1 hybrid consisted of three euploids: two octoploids $(8 \mathrm{x}=56)$ and one decaploid $(10 \mathrm{x}=70)$. Aneuploids prevailed in progeny of the MP-F $F_{1}$ there were 32 plants with chromosome numbers between 40 and 49 , one octoploid and 28 hypo-decaploids, with 60 to 69 chromosomes (table 1). The quasihexaploids of the first group showed various level of weakness and sterility, but in the following generations most of the progenies quickly regulated their chromosome complement and restored fertility, usually with help of additional spontaneous back-cross to A. sativa. Eleven of these cytogenetically unbalanced progenies produced valuable and stable hexaploid $(6 x=42)$ breeding strains. The octoploids, less frequent than expected, gave also rise to cytogenetically stable stocks. The descendants of the hypo-decaploid primary synthetics were less vigorous than the octoploids or hexaploids and their propagation required verification of ploidy level at reproduction, as 
there was a tendency to spontaneous decrease of number of chromosomes.
Таблица 1. Распределение числа хромосом в проростках гибридов $\mathrm{B}_{1} \mathrm{~F}_{1}$ и $\mathrm{F}_{2}$ от скрещивания Avena sativa $\times$ A. macrostachya
Table 1. Distribution of chromosome numbers in the $B_{1} F_{1}$ and $F_{2}$ generation seedlings of the Avena sativa $\times$ A. macrostachya hybrids

\begin{tabular}{|c|c|c|c|c|c|c|c|c|c|c|c|c|c|c|c|c|c|c|c|c|c|c|}
\hline \multirow{2}{*}{$\begin{array}{c}\mathrm{F}_{1} \\
\text { mother } \\
\text { parent }\end{array}$} & \multicolumn{22}{|c|}{ Number of chromosomes } \\
\hline & f & F & $\stackrel{\mathcal{f}}{ }$ & $\mathscr{q}$ & ஓ & 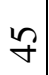 & o & 于 & $\underset{+}{\infty}$ & $\stackrel{\vartheta}{\sigma}$ & ㄴ) & 8 & $\overline{6}$ & $\widetilde{\sigma}$ & $\tilde{6}$ & ț & 6 & : & $\widehat{6}$ & $\begin{array}{l}\infty \\
0\end{array}$ & $\hat{\jmath}$ & $\stackrel{P}{2}$ \\
\hline $\mathrm{W}-\mathrm{F}_{1}$ & & & & & & & & & & & 2 & & & & & & & & & & & 1 \\
\hline${\mathrm{MP}-\mathrm{F}_{1}}_{1}$ & 2 & 3 & 4 & 3 & 4 & 4 & 1 & 3 & 1 & 1 & 1 & 1 & 1 & & 3 & 5 & 5 & 3 & 5 & 2 & 2 & \\
\hline $\begin{array}{l}\text { dead } \\
\text { MP* }\end{array}$ & & & 1 & & 2 & 1 & 1 & 1 & & & & & & & & 1 & & & & & & \\
\hline
\end{tabular}

*plants which produced seminal roots for chromosome counting but died at germination (from Lapinski, Podyma, 2007)

\section{The octoploids as a new species comparable to primary triticales}

An abiotic stress response is usually determined by numerous interacting genes, thus, recombination itself, usually restricted by reduced meiotic pairing, may not be effective in transfer of all necessary genes. Creation of alloploids makes it possible to transfer a whole genetic system (set of chromosomes) controlling a trait(s) of interest. Triticale is a convenient reference species to compare results of transfer of abiotic stress tolerance through whole genome transfer; it exceeds wheat and its introgressive interspecific recombinants in resistance to drought, soil salinity and acidity (Hede, 2001). It requires less nitrogen and water than wheat to produce a similar yield. Triticale winterhardiness was a more difficult breeding objective but a few decades were sufficient to restore expression to the level of parental species. No such incompatibility of winterhardiness genetic systems occurred in our sativa-macrostachya alloploids; first generations of the obtained octoploids exceeded their hexaploid common oat parents in winter hardiness. The $8 \mathrm{x}$ line PR-4H8 had the best survival scores in UOWHN 2010. However, we did not observe in the octoploids any further progress in the trait expression compared to that recorded recently in the hexaploid wide hybrids. Probably, lack of appropriate variation is the cause. As yet, our attempts to produce secondary winter octoploids through crossing hexaploids with decaploids are unsuccessful: in 24 crosses of this type progenies shifted to the $6 \mathrm{x}$ ploidy level. Variation in our octoploids comes mainly from recombination initiated by the back-cross of interspecific $F_{1}$ to A. sativa. The most interesting lines, including the PR-4H8,

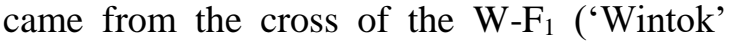
based) with Welsh line 95-43Cn4 (the only line among the pollen parents which had a black hull marker enabling parentage control). The sativa-macrostachya octoploids produce large, elongated seed (in nurseries TKW up to $70 \mathrm{~g}$ ), plump and rich in protein (up to 20\%) but with poor beta-glucan content (ca. 2,7\%). The seed quality in these octoploids was much better than shrivelled and frequently sprouted seed of early wheat-rye alloploids. Yield of grain of the oat octoploids approximated to $50-67 \%$ of the good hexaploid winter forms and its average value in the years with winter survival is similar to that of common spring oat. Yield potential of the octoploids is probably underestimated, because of an uncontrolled negative effect of wild animals selectively grazing on the trial plots, which occurs regularly in early spring at our location. Leaf diseases resistance is high and green mass abundance is suggesting usefulness for green forage or silage. In cultivation of the octoploids for grain, late and non-uniform ripening may be problematic in some years (the wild component is a perennial plant with prolonged tillering phase). Care must be taken regarding the disappearance of resistance to diseases in single $8 x$ lines. We noticed loose smut, which was never recorded before in the location, on a few of the $\mathrm{W}-\mathrm{F}_{1}$ lines. The loss of some genes (or a loss of their function) may be attributed to recombination of heterologously translocated chromosomes or rapid sequence elimination and epigenetic modifications (Ma and Gustafson 2008) which occur in early generations 
of new alloploids. Continuing the comparison with first wheat-rye hybrids, grain yield potential of early triticales from CIMMYT was reported as ca. $2.4 \mathrm{t} / \mathrm{ha}$. After three decades of breeding (nearly 60 generations) it reached 10 $\mathrm{t} /$ ha (Hede, 2001). The $2 / 3$ of common oat yield in our raw octoploids makes for a much better starting point. Considering the most dis- tant systematic position of A. macrostachya in relation to $A$. sativa and other oat species in the genus, the relatively high performance of the octoploids could not only justify their breeding as a separate crop, but should also encourage the use of other Avena species in oat improvement through whole genome addition or substitution

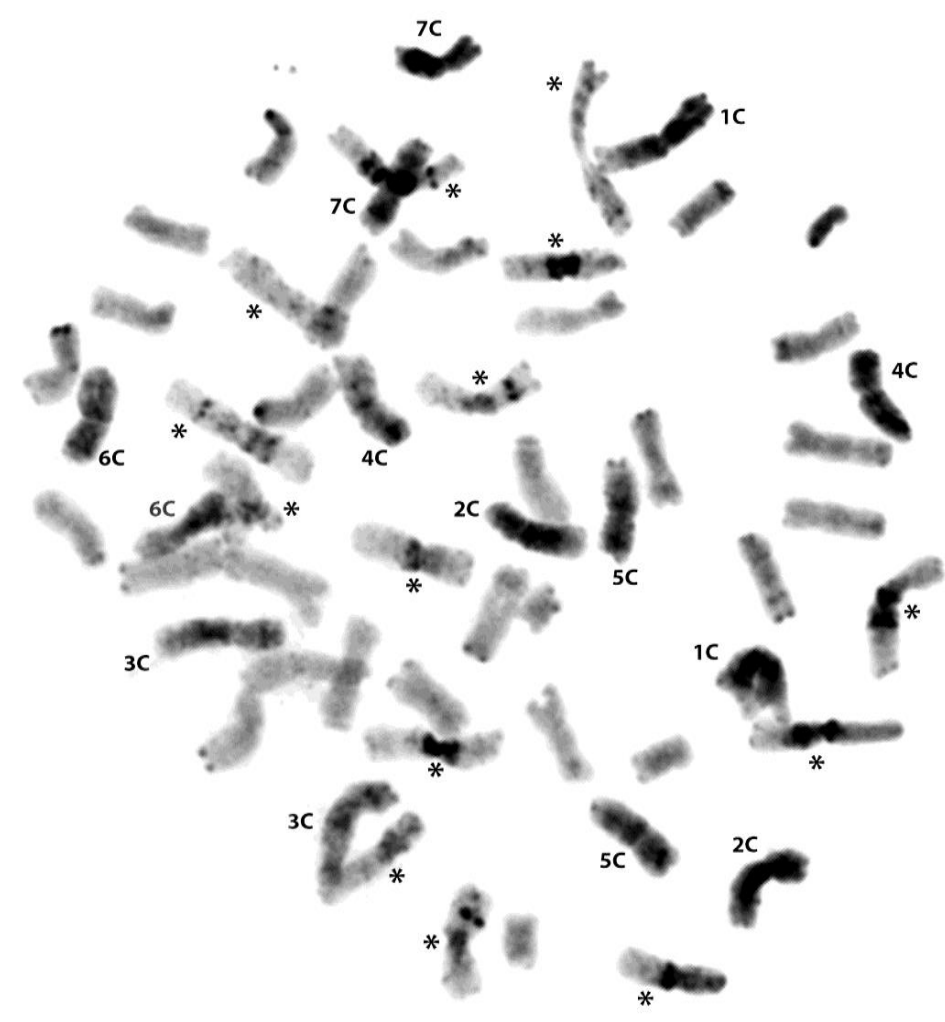

Рисунок. Хромосомный набор, окрашенный по Гимза, 56-хромосомного стабильного аллоплоида PR-4H8, полученного при В-кроссировании A. sativa (cv. Wintok') × A. macrostachya $\times$ A. sativa (95-43Cn4).

Хромосомы 'macrostachya' помечены звездочкой. Хромосомы С-генома A. sativa помечены цифрами (преп. E. Jellen, приведено из работы Lapinski et al., 2013).

Figure. The Giemsa C-banded chromosome complement of the stable 56-chromosome alloploid PR-4H8 from an interspecific back-cross of $A$. sativa (cv. Wintok') $\times$

A. macrostachya $\times$ A. sativa $(95-43 \mathrm{Cn} 4)$.

The 'macrostachya' chromosomes marked with asterisks. C-genome $A$. sativa chromosomes are numbered (prep. by E. Jellen, from Lapinski et al., 2013).

\section{Hexaploid progeny of the wide crosses}

The unexpected 40-49 chromosome plants of the MP- $\mathrm{F}_{1}$ progeny resulted most probably from irregularly reduced female gametes fertilized with normal 21-chomosomal male gam- etes of common oat. Such back-crosses should facilitate homeologous recombination and produce more unique genotypes than the products of 'academic' back-crosses of hexaploids with octoploids, aimed at promoting introgression. Conjugation of A. macrostachya chromosomes 
with those of A. sativa is possible but poor (Leggett, 1985), thus, in the 6x x 8x $F_{1}$, they are expected to remain unpaired, particularly when the sativa chromosomes form competitive bivalents. Finally, the most probable result should be a loss of the alien chromosomes without any introgression. Forcing of homeologous recombination and better chances for maintenance of alien germplasm may occur in progeny created from a selection of gametes with random chromosome composition. Therefore, high numbers of independent recombinant lines were derived from the MP-F 1 quasihexaploids in the next generations. Their selection and stabilization was accompanied with division into winter or spring types, according to response to the occurring low winter temperatures. After four years in nurseries, the first winter hardy strains were directed to field trials. Some of them showed winterhardiness levels higher than the lines from the foreign oat collection or the UOWHN nursery objects. Two husked lines were sent to the international UOWHN nurseries in 2011 and 2012, where they reached top scores of winter survival. Moreover, investigation of the 2011 UOWHN nursery objects with the winterhardiness DNA markers set, developed in the University of North Carolina (Wooten et al., 2008), revealed the lowest number of the frost resistance markers in our 5Q5.2 line, in spite of the highest phenotypic winterhardiness record (Lapinski et al. 2013). It confirmed uniqueness of the resistance source. Yields of the both UOWHN studied lines were satisfactory in two-locations field trials, thus they were directed to the Polish state variety trials in 2014 and 2015. The line 5Q5.2 (proposed cultivar name 'Radzikus') is of medium height, yielding grain with relatively high test weight (in Radzików ca. $60 \mathrm{~kg} / \mathrm{hl}, 2-3 \mathrm{~kg} / \mathrm{hl}$ more than the average for winter oat and ca. $4 \mathrm{~kg} / \mathrm{hl}$ better than the spring standard) and relatively high oil content (see table 4). The other line 5T8.A is $10-20 \mathrm{~cm}$ taller (but not less resistant to lodging), has a larger grain and shows resistance to mildew. In the Polish weather conditions, both lines are of facultative type, however late sowing in some environments may cause problems with delayed heading. Yielding of these lines is shown in tables 2 and 3 , in relation to winter barley and spring oat standards. In Radzików, the average yield of 5Q5.2 in five seasons with good winter survival reached $90,4 \%$ of the winter barley standard ('Carola') and was much better $(141,2 \%)$ than average yield of the spring oat standard ('Kre- zus'). Two years with winter killing (2012 and 2016) resulted in lower values at $64,6 \%$ and $100,8 \%$, respectively. However, considering the ca. $7 \mathrm{dt} / \mathrm{ha}$ yield equivalent necessary to pay for re-sowing of a winter killed plantation, the winter oat remains economically still very competitive to spring one. In Radzików, in a season with winter survival, average advantage of winter oat yield over the spring one is 20,1 $\mathrm{dt} / \mathrm{ha}$, which compensates almost for three years of winter killing losses. In the submountaineous station Grodkowice, where the 5Q5.2 oat died only in 2016, the results are even more attractive. The average yield reached $91,3 \%$ of the average barley yield. Considering only the period 2012-2015 with good winter survival of oat, the line overyielded the winter barley check (114.3\%).

On less fertile sandy soils, winter killing risk is much higher and yield compensation, in relation to spring form, is smaller, thus carefulness and local trials are recommended before large scale planting. The year 2011 was conducive for oat growth in Radzików and the potential for yield quantity and quality was well expressed for both winter and spring forms. The basic quality parameters for some bulks and advanced lines, shown in table 4, confirmed good quality of hexaploid winter oats derived from the interspecific crosses, in comparison with the spring oat standard and the 'mix $\mathrm{W}$ ' protein rich bulk from a spring $\mathrm{x}$ winter A. sativa intraspecific cross.

\section{Relevance of the alloploids in winterhardi- ness improvement}

The last winter 2015/2016 was the most destructive in Poland since last 25 years, in spite of relatively high average winter temperatures. In Radzików the first significant frost of $-14^{\circ} \mathrm{C}$ suddenly attacked, without snow cover, in January 2-6 and totally killed more than $1 / 3$ of winter oats in nurseries and in field trials. The lines which survived the first attack of winter showed a wide scope of damage level. However, during the following two months with temperatures oscilating near $0^{\circ} \mathrm{C}$ the surviving plants lost green colour and were not able to grow and regenerate. Finally, all oats died, while the winter barley standard stayed alive. Oat survival in Poland in 2016 was only possible in the south-western part of the country, where snow cover supplied sufficient protection against frost (and, probably, solarization).

Variation in frost resistance scores (collected shortly after the January frost) is presented 
in Table 5. for various groups of crosses in- Radzików field trials, derived from 45 cross volving hexaploids, octoploids and decaploids. combinations, classified into 8 groups. The results are based on 147 lines from

Таблица 2. Урожайность (ц/га) некоторых озимых межвидовых гибридов и стандартных яровых овсов. Радзиков, 2009-2016 гг. Минимальная температура $\left({ }^{\circ} \mathrm{C}\right)$ дана на поверхности почвы) Table 2. Yields (dt/ha) of some winter oat interspecific hybrids together with winter barley and spring oat standards. Radzików, 2009-2016.

The minimal temperatures $\left({ }^{\circ} \mathrm{C}\right)$ are given for ground surface

\begin{tabular}{l|l|l|l|l|l|l|l|l|l|l}
\hline $\begin{array}{l}\text { Year }{ }^{\circ} \mathrm{C} \\
\text { Line }\end{array}$ & $\begin{array}{c}2009 \\
-8,0\end{array}$ & $\begin{array}{c}2010 \\
-5,2\end{array}$ & $\begin{array}{c}2011 \\
-9,5\end{array}$ & $\begin{array}{c}2012- \\
14,3\end{array}$ & $\begin{array}{c}2013 \\
-5,8\end{array}$ & $\begin{array}{c}2014 \\
-5,7\end{array}$ & $\begin{array}{c}2015 \\
-8,7\end{array}$ & $\begin{array}{c}2016- \\
14,0\end{array}$ & $\begin{array}{c}\bar{x} \\
\text { all } \\
\text { years }\end{array}$ & $\begin{array}{c}\bar{y} \\
\text { surv. } \\
\text { years }\end{array}$ \\
\hline $\begin{array}{l}\text { Carola } \\
\text { winter bar- } \\
\text { ley }\end{array}$ & 79,8 & 66,9 & 82,2 & $\begin{array}{l}\text { not } \\
\text { studied }\end{array}$ & 57,2 & 90,0 & 81,3 & $\begin{array}{l}\text { not } \\
\text { studied }\end{array}$ & 76,2 & 76,2 \\
\hline $\begin{array}{l}\text { Krezus } \\
\text { spring oat }\end{array}$ & 33,8 & 50,4 & 76,0 & $\begin{array}{l}\text { not } \\
\text { studied }\end{array}$ & 33,8 & 56,0 & 43,0 & $\begin{array}{l}\text { not } \\
\text { studied }\end{array}$ & 48,8 & 48,8 \\
\hline 5Q5.2 & - & 76,8 & 80,0 & dead & 57,8 & 73,0 & 56,9 & dead & 49,2 & 68,9 \\
\hline 5T8.A & - & - & 75,7 & dead & 65,5 & 83,7 & 44,7 & dead & 44,9 & 67,4 \\
\hline $\begin{array}{l}\text { best 6x w. } \\
\text { oat }\end{array}$ & 62,8 & 81,8 & 79,3 & dead & 65,7 & 99,8 & 64,0 & dead & 56,8 & 75,7 \\
\hline $\begin{array}{l}\text { best } 8 \mathrm{x} \text { w. } \\
\text { oat }\end{array}$ & 36,3 & 56,3 & 53,2 & dead & 45,7 & 65,0 & 38,0 & dead & 36,8 & 49,1 \\
\hline
\end{tabular}

Таблица 3. Урожайность (кг/м²) некоторых межвидовых озимых гибридов овса и стандартов ячменя. Гродкович, 2012-2016 гг.

Table 3. Yields $\left(\mathrm{kg} / 10 \mathrm{~m}^{2}\right)$ of some winter oat interspecific hybrids and winter barley standard. Grodkowice, 2012-2016

\begin{tabular}{l|c|c|c|c|c|c|c}
\hline $\begin{array}{l}\text { Year } \\
\text { Line }\end{array}$ & 2012 & 2013 & 2014 & 2015 & 2016 & $\begin{array}{c}\bar{x}, \text { all } \\
\text { years }\end{array}$ & $\begin{array}{c}\bar{x}, \text { survival } \\
\text { years }\end{array}$ \\
\hline $\begin{array}{l}\text { Carola } \\
\text { winter bar- } \\
\text { ley }\end{array}$ & $\begin{array}{c}(133,7) \\
\text { border } \\
\text { effect }\end{array}$ & 42,5 & 68,2 & 82,9 & $\begin{array}{c}\text { not } \\
\text { studied }\end{array}$ & 64,5 & 64,5 \\
\hline 5Q5.2 & 81,8 & 66,7 & 64,3 & 81,8 & dead & 58,9 & 73,7 \\
\hline 5T8.A & 67,2 & 47,1 & 64,8 & 76,6 & dead & 51,1 & 63,9 \\
\hline $\begin{array}{l}\text { best 6x w. } \\
\text { oat }\end{array}$ & 81,8 & 66,7 & 82,2 & 86,4 & dead & 63,4 & 79,3 \\
\hline
\end{tabular}

Each cross combination is represented in the table by only one line with the best frost resistance. The group 1. of hexaploid lines or bulks derived from spontaneous pollinations of the interspecific MP- $\mathrm{F}_{1}$, containing the 5T8.A and 5Q5.2 cultivar candidates, showed no more the best winterhardiness. The octoploids (group 2) maintained their resistance level, but the most hardy four oat lines, with scores higher than 6, were hexaploid. They had the $\mathrm{W}-\mathrm{F}_{1}$ derived octoploid parent or grandparent (best score 6) as a source of the resistance. The other octoploid (MP-F F $_{1}$ showed lower level of resistance (score 4), related to distinctly lower winterhardiness of its MP (Mirabel/Pendragon) initial wide cross parent. The difference attributable to these two grand-parental $6 \mathrm{x}$ forms is maintained, however less distinct in the groups of $6 \mathrm{x} \times 10 \mathrm{x}$ crosses. Considering the 9 best cross combinations with top scores higher than 5, presence of an alloploid (8x or 10x) in a line parentage seems essential for high expression of frost resistance, while the resistance level of the other (hexaploid) parent was less important. It suggests a low number of 'strong' genetic loci involved. An oat object with the score 8 has the spring cultivar ('Buggy') as mother cross component. Another 
spring line (from 'Strzelce' Breeding Co.) ative, as shown for other spring parents in brought also, as a grandparent, a remarkable comparisons between groups 4 and 5 or 7 and contribution to the other two transgressive 8. Winterhardiness alleles in spring oat were genotypes with scores 9 and 7. The high pro- reported earlier by Amirshahi and Patterson portion of spring oat genes in the elite winter (1956), Murphy (1958) and Wooten et al. type materials is surprising, however, in gen- (2008).

eral, their influence on winterhardiness is neg-

Таблица 4. Параметры качества урожая озимого овса (голозерного типа) в Радзиков (2010/2011 гг.). Буквами а-g обозначены турецкие группы результатов урожайности Table 4. Winter oat (husked type) yield quality parameters from the 2010/2011 field trial in Radzików. The a-g designations are for Tukey's grouping of yield results

\begin{tabular}{|c|c|c|c|c|c|c|}
\hline Line & $\begin{array}{c}\text { yield } \\
\mathrm{kg} / 10 \mathrm{~m}^{2}\end{array}$ & $\begin{array}{c}\text { protein } \\
\%\end{array}$ & fibre $\%$ & oil \% & $\begin{array}{c}\text { TKW } \\
\text { g }\end{array}$ & $\begin{array}{c}\% \\
\text { of husk }\end{array}$ \\
\hline Krezus (spring oat check) & $7,60 \mathrm{ab}$ & 14,6 & 7,2 & 5,2 & 37,4 & 21,8 \\
\hline 5Q5.2 ('Radzikus') $6 \mathrm{x}$ & $8,00 \mathrm{a}$ & 16,3 & 5,1 & 7,0 & 36,5 & 23,6 \\
\hline mix M (hybrid bulk) 6x & $7,92 a b$ & 15,1 & 8,5 & 6,3 & 43,1 & 22,7 \\
\hline 5T8.A & 7,57 abc & 17,1 & 5,4 & 5,1 & 53,3 & 26,3 \\
\hline mix W ('sativa'bulk) 6x & $7,22 \mathrm{abc}$ & 19,2 & 5,3 & 3,7 & 46,6 & 24,6 \\
\hline 5P8.31 & 6,97 abcd & 17,1 & 6,6 & 6,8 & 51,5 & 24,4 \\
\hline 508.aa & 6,17 defg & 15,5 & 7,9 & 4,8 & 52,8 & 24,0 \\
\hline 4H8 (bulk) & 5,45 efg & 18,6 & 6,4 & 6,3 & 61,0 & 24,9 \\
\hline $4 \mathrm{H} 8.8$ & $5,32 \mathrm{fgh}$ & 19,8 & 5,8 & 5,9 & 61,5 & 25,0 \\
\hline
\end{tabular}

(from Lapinski et al., 2012)

Таблица 5. Распределение по морозостойкости различных скрещиваний озимого овса. Радзиков, 2016 г. Шкала 1 - гибель, 2-9 - уровень устойчивости. Каждое скрещивание представлено наиболее зимостойкой линией.

Table 5. Distributions of frost resistance scores for various groups of winter oat crosses. Radzików, 2016. Score 1 means total killing, 2 to 9 describe ascending levels of resistance. Each cross is represented by its most winterhardy line.

\begin{tabular}{|c|c|c|c|c|c|c|c|c|c|c|c|c|c|c|}
\hline \multirow{2}{*}{$\begin{array}{c}\text { Group } \\
\mathrm{Nr}\end{array}$} & \multirow{2}{*}{\multicolumn{2}{|c|}{$\begin{array}{c}\text { Parents and prog- } \\
\text { eny } \\
\text { ploidy levels }\end{array}$}} & \multirow{2}{*}{$\begin{array}{l}\text { Winter } \\
\text { or } \\
\text { spring }\end{array}$} & \multicolumn{9}{|c|}{ Resistance scores } & \multirow{2}{*}{$\begin{array}{l}\text { No. of } \\
\text { crosses }\end{array}$} & \multirow{2}{*}{$\begin{array}{l}\text { Mean } \\
\text { score }\end{array}$} \\
\hline & & & & 1 & 2 & 3 & 4 & 5 & 6 & 7 & 8 & 9 & & \\
\hline 1. & $\begin{array}{l}\text { MP-F } 5 x * 6 \\
6 x\end{array}$ & $>$ & & 3 & 6 & 1 & & & & & & & 10 & 1,8 \\
\hline 2. & $\begin{array}{l}F_{1} 5 x * 6 x \\
8 x\end{array}$ & & $\mathrm{w} * \mathrm{w}$ & & & & 1 & & 1 & & & & 2 & 5 \\
\hline 3. & $6 x * 6 x$ & $>6 x$ & $\mathrm{w} * \mathrm{w}$ & 2 & 1 & 2 & & 1 & & & & & 6 & 2,5 \\
\hline 4. & \multirow{2}{*}{\multicolumn{2}{|c|}{$6 x * W 8 x>6 x$}} & $\mathrm{w} * \mathrm{w}$ & 2 & & 1 & & & 1 & 1 & & 2 & 7 & 5,1 \\
\hline 5. & & & $\mathrm{~s} * \mathrm{w}$ & 4 & & 1 & 2 & & & & 1 & & 8 & 2,9 \\
\hline 6. & $6 \mathrm{x} * \mathrm{~W} 10 \mathrm{x}$ & $>6 x$ & $\mathrm{w} * \mathrm{w}$ & & & 1 & & 2 & 1 & & & & 4 & 4,8 \\
\hline 7. & \multirow{2}{*}{\multicolumn{2}{|c|}{$6 x *$ MP10x $>6 x$}} & $\mathrm{w} * \mathrm{w}$ & 2 & & & 1 & & 2 & & & & 5 & 3,6 \\
\hline 8. & & & $\mathrm{~s} * \mathrm{w}$ & 3 & & & & & & & & & 3 & 1 \\
\hline Total & & & & 16 & 7 & 6 & 4 & 3 & 5 & 1 & 1 & 2 & 45 & 3,2 \\
\hline
\end{tabular}

Effectiveness of the $6 x \times 8 x$ alloploid back- alien chromosomes. Finally, there is still no crosses was unexpectedly high, considering the certainty about contribution of $A$. expected low level of meiotic homoeologous macrostachya genes in the recorded progress, conjugation and the resulting elimination of sole intraspecific recombination effects cannot 
be excluded until molecular verification of the alien source hypothesis is produced. Even when the interspecific gene exchange may not be a major factor, alloploid back-cross seems still attractive as a prospective version of 'incorporation' breeding strategy (Simmonds, 1993), which is usually based on secondary intercrossing among independently introgressed lines of a distant cross, aimed at restoration of a trait genetic architecture disrupted by interspecific recombination. The most frustrating restriction in breeding for winterhardiness is a decrease of yielding potential associated with increase of resistance to winter stress. The physiological basis of this link, related to deepness and duration of dormancy period in winter, is also known in crops other than oat. The only way to keep yield high is breeding for cultivars with the lowest acceptable level of winterkill resistance in the targeted area (Reynolds et al., 2001).

A year ago the 'Radzikus' 5Q5.2 cultivar candidate seemed to have the most optimal combination of winterhardiness and yielding capacity, reaching in 2015 70,0\% and 98,7\% of the barley check yield in Radzików and Grodkowice, respectively. Three new lines were identified which were more productive than 5Q5.2 in 2015 while being also more winterhardy in the current season. The best of these lines combined $84,2 \%$ of the barley check yield (in Radzików, 2015) with the highest possible frost resistance score 9. The corresponding 2016 score for 5Q5.2 was only 2. It opens new prospects to rise level of the yield-resistance compromise in oat. The elite includes also one line of naked oat with winterhardiness score 6 . Hulless forms from earlier crosses were generally classified as insufficiently resistant to winter killing. The elite resistant line comes from a cross involving a winter naked common oat and the 'Wintok' derived octoploid. Its yield in Radzików in 2015 was very low ( $3 \mathrm{dt} / \mathrm{ha}, 39,8 \%$ of the winter barley standard). Better result recorded for that line in Grodkowice (56,2\% of the barley check) could make it more competitive to spring naked oat.

\section{Conclusions}

1. Relatively high performance of the sativa-macrostachya octoploids underline the potetential for use of alloploidy in improvement of oat.

2. Crosses of common oat with $8 \mathrm{x}$ or $10 \mathrm{x}$ sativa-macrostachya alloploids proved to be effective in transgressive improvement of winterhardiness.

3. Some spring oats confirmed their value as good cross components for winterhardiness improvement.

4. In spite of the risk of winter killing, cultivation of the hexaploid oat wide hybrids in Poland is economically feasible on sufficiently fertile soils in regions with stable snow cover.

\section{References/Литература}

Amirshahi M. C., Patterson F. L. 1956. Cold resistance of parent varieties, F2 populations and

F3 lines of 20 oat crosses. Agron J, 48, pp. 184188.

Hede A. 2001. A New Approach to Triticale Improvement. Paper presented at the Research

Hermann M. 2006. Introgressed from $A$. macrostachya monogenic inheritance of powdery mildew resistance. Available from http:// www.bafz.de/JB2003/ilk.pdf

Highlights of the CIMMYT Wheat Program, 19992000, Oaxaca, Mexico.

Lapinski B., Kala M., Boczkowska M. 2012. Creation of Polish forms of winter oat based on crosses with Avena macrostachya. Proc. $9^{\text {th }}$ Int. Oat Conference. 20-23 June 2012, Beijing, China.

Lapinski B., Kala M., Nakielna Z., Jellen R., Livingston D.P. 2013. The perennial wild species Avena macrostachya as a genetic source for improvement of winterhardiness in winter oat for cultivation in Poland. In: Biotechnology and Plant Breeding - Perspectives. Eds: R.K. Behl and E. Arseniuk, Agrobios (International) Publishers, Jodphur, India, pp. 51-62.

Lapiński B., Podyma W. 2007. Polish hybrids of cultivated oats with Avena macrostachya. Proc. 18th. EUCARPIA Meeting, Genetic Resources Section, Pestany, May 23-26.

Leggett J. M. 1985. Interspecific hybrids involving the perennial oat species Avena macrostachya. Can. J. Genet. Cytol., vol. 27, pp. 29-32.

Livingston D. P. III, Elwinger G. F. 1995. Improvement of winter hardiness in oat from 1935 to 1992. Crop Sci., 35, pp. 749-755.

Livingston D.P.III, Elwinger G. F., Murphy J. P. 2004. Moving beyond the Winter Hardiness Plateau in U.S. Oat Germplasm. Crop Sci., 44, pp. 1966-1969.

Loskutov I. G. 2007. Oat (Avena L.). Distribution, taxonomy, evolution and breeding value. St. Petersburg: SSC RF VIR, 2007, 336 p. 
Ma X. F., Gustafson J. P. 2008. Allopolyploidization-accomodated Genomic Sequence Changes in Triticale. Ann Bot., 101(6), pp. 825-832.

Murphy H. C. 1958. Registration of oat varieties, XXI. Agron J., 50:701.

Reynolds M. P., Ortiz-Monasterio J. I., McNab A. M. 2001. Application of Physiology in Wheat Breeding. Mexico, D.F.: CIMMYT

Santos A., Livingston D. P., Murphy J. P. 2002. Agronomic, cytological and RAPD evaluations of Avena sativa x A. macrostachya populations. Eastern Wheat Workers and Southern Small Grain Workers Proceedings. Raleigh, North Carolina, USA.
Simmonds N. W. 1993. Introgression and incorporation, strategies for the use of crop genetic resources. Biol. Rev., 68, pp. 539-562.

Weibull J. 1988. Resistance in the wild crop relatives Avena macrostachya and Hordeum bogdanii to the aphid Rhopalosiphum padi. Entomologia Experimentalis et Applicata, 48: 225232.

Wooten D., Livingston D. P., Holland J. B., Marshall D. S., Murphy J. 2008. Quantitative trait loci and epistasis for crown freezing tolerance in the Kanota $\mathrm{x}$ Ogle hexaploid oat mapping population. Crop Science. 48:149-157. 


\section{Е. А. Пороховинова}

Федеральный

исследовательский центр

Всероссийский институт

генетических ресурсов

растений имени

Н. И. Вавилова,

190000 Санкт-Петербург,

ул. Б. Морская д. 42,44 ,

Россия,

e-mail: e.porohovinova@vir.nw.ru

\section{Ключевые слова:}

Linum usitatissimuт, генетическая коллекиия, гены $R f$, дискриминантный анализ, плейотропный эффект ЦМС, трубчатая форма цветка

Поступление:

25.12.2016

Принято:

06.03.2017
ОРИГИНАЛЬНАЯ СТАТЬЯ

\section{ГЕНЕТИЧЕСКИЙ КОНТРОЛЬ ВОССТАНОВЛЕНИЯ ФЕРТИЛЬНОСТИ ПЫЛЬЦЫ У ЛИНИЙ ЛЬНА (LINUM USITATISSIMUM L.) С ЦИТОПЛАЗМАТИЧЕСКОЙ МУЖСКОЙ СТЕРИЛЬНОСТЬЮ}

Актуальность. Цитоплазматическая мужская стерильность (ЦМС) широко применяется для создания гетерозисных гибридов многих культурных растений. У льна описано около 5 типов ЦМС, большинство из которых не сохранилось. Вновь выделенные источники ЦМС могут быть вовлечены в гетерозисную селекцию. Материал и методы. В качестве источников ЦМС использованы три линии. Гк-204 (Cyt ${ }^{\mathrm{s} 1}$ - тип цитоплазмы) обладает открытым цветком с укороченными, изогнутыми тычиночными нитями и стерильными, практически без пыльцы, пыльниками, но завязывает немного семян при самоопылении в конце вегетационного периода. Линии гк-208 $\left(\mathrm{Cyt}^{\mathrm{t} 2}\right)$ и гк-188 $\left(\mathrm{Cyt}^{\mathrm{t} 3}\right)$ абсолютно фертильны, стерильность проявляется только в результате гибридизации с другими линиями. У $\mathrm{F}_{2}$ окончательное разделение на классы по стерильности проводили исходя из завязываемости коробочек и семян с применением дискриминантного анализа. Результаты. В $F_{2}$ всех скрещиваний были реципрокные различия. В прямом направлении выщеплялись стерильные гибриды, часто с трубчатыми цветками, препятствующими перекрестному опылению, а в обратном - растения всегда фертильны. У стерильных гибридов были изогнутые, укороченные тычиночные нити. В скрещиваниях гк-204 (†) с гк-2, 368, 255 восстановления фертильности не происходит и расщепление только по форме стерильного цветка. В скрещиваниях гк-204 (rfoб) $\times$ гк-53 (rft3-2) и гк-208 × гк-124 (rft3-7, rfo-6-2) расщепление соответствовало 9 фертильных открытых: 3 стерильных открытых: 1 стерильных трубчатых, для гк-204 (rfo6) $\times$ гк-176 (rfo-7, rft3-6) оно было 27:21:16, для гк-208 × гк-210 (rfo6-3, rft6, rft7) - 54:9:1, а для гк-188 × гк-103 (rfo7, rft5$2)$ - 12:3:1. У гибридов гк-204 (rfo6) с гк-129 и 208 наблюдали расщепление только по стерильности открытых цветков - 3:1, а у гк-204 (rfo6) $\times$ гк458 (RFO8, RFO9) - 57:7. Выводы. Выявленные аллели генов восстановления фертильности по характеру проявления можно отнести к трем типам. Первые имеют большую селекционную ценность для введения в источники ЦМС, так как, не мешая проявлению стерильности, не влияют на форму венчика (rfo6, rfo6-2, rfo6-3, rfo7). Вторые - контролируют трубчатые стерильные цветки и могут быть как рецессивными (rft3-2, $r f t 3-3, r f t 3-6, r f t 3-7, r f t 5-2, r f t 6, r f t 7)$, так и доминантными (RFT4-3). Они нежелательны для селекции, так как снижают вероятность перекрестного опыления. Третьи (RFO8, RFO9), восстанавливают фертильность у гибридов со стерильной цитоплазмой и геном $r f o 6$ будут востребованы в гетерозисной селекции. Возможно гены, имеющие одинаковые префиксы аллельны, например, $r f o 6-2, r f o 6-3$, но тесты на аллелизм для них не проводились. 


\section{E. A. Porokhovinova}

The N. I. Vavilov

All-Russian Institute of Plant Genetic Resources, 42, 44, Bolshaya Morskaya str., St. Petersburg, 190000 Russia, e-mail: e.porohovinova@ vir.nw.ru

\section{Key words:}

Linum usitatissimum, genetic collection, Rf genes, discriminant analysis, pleiotropic effect of CMS, tubular shape of the flower

\section{Received:}

25.12.2016

\section{Accepted:}

06.03.2017

\section{GENETIC CONTROL OF FERTILITY RESTORATION IN CMS LINES OF FLAX (LINUM USITATISSIMUM)}

Background. Cytoplasmic male sterility (CMS) is widely used for producing heterotic hybrids of many cultivated plants. For flax, about 5 types of CMS were described, but most of them did not survive. Newly identified sources of CMS may be involved in heterosis breeding. Material and methods. As a source CMS, three lines were used. Gc-204 has an open flower with short, curved stamen filaments and sterile anthers, with almost no pollen, but forms few seeds after self-pollination in the end of the growing season. Lines gc-208 and gc-188 are absolutely fertile; their sterility is manifested only as a result of hybridization with other lines. In $F_{2}$, final division into sterility classes was carried out on the basis of the formed bolls and seeds using discriminant analysis. Results. All crosses showed reciprocal differences in $F_{2}$. Direct crosses resulted in sterile hybrids, often having tubular flowers that prevent cross-pollination, but in reverse crosses the progeny was always fertile. Sterile hybrids had curved, short filaments. In the crosses of gc-204 (P) with gc-2, 368, 255 restoration of pollen fertility didn't occur, and segregation was observed only in the shape of sterile flowers. In crosses gc-204 $(r f o 6) \times \mathrm{gc}-53(r f t 3-2)$ and gc-208 $\times$ gc-124 ( $r f t 3-7, r f o-6-2)$ segregation in $\mathrm{F}_{2}$ corresponded to 9 open fertile flowers: 3 open sterile flowers: 1 tubular sterile flower; for gc-204 $(r f o \sigma) \times \mathrm{gc}-176(r f o-$ 7,rft3-6) it was 27:21:16; for gc-208 $\times$ gc-210 (rfo6-3,rft6 rft7) it was $54: 9: 1$; for gc- $188 \times$ gc-103 (rfo $7, r f t 5-2)$ it was $12: 3: 1$. In the hybrids of gc204 ( $r f o 6$ ) with gc-129 and 208, segregation was observed only in the sterility of open flowers (3:1), while in the cross gc-204 $(r f o 6) \times \mathrm{gc}$ 458(RFO8, RFO9) it was 57:7. Conclusions. The identified alleles of fertility restoration genes can be attributed to three types according to the nature of their manifestation. The first one has a greater breeding value for its introduction into the sources of CMS, as their alternative allels don't affect the corolla's shape along with sterility manifestation ( $r f o 6, r f o 6-2, r f o 6-3$, rfo7). The second type controls tubular sterile flowers, and can be both recessive (rft3-2, rft3-3,rft3-6,rft3-7, rft5-2,rft6, rft7) and dominant (RFT4-3). They are undesirable for breeding because they reduce the probability of cross pollination. The third type (RFO8, RFO9) restores fertility in hybrids with sterile cytoplasm and the $r f o 6$ gene, and will be useful in heterosis breeding. Probably the genes having the same allelic prefixes, for example, rfo6-2, rfo6-3, are the allelic ones, but the tests for their allelism have not been carried out. 


\section{Введение}

Цитоплазматическая мужская стерильность (ЦМС) широко используется для создания гетерозисных гибридов у многих культурных растений. Как правило, она появляется в отдаленных скрещиваниях, или соматической гибридизации, выщепляется при длительном самоопылении, или в результате сомаклональной изменчивости (Danilenko, Davydenko, 2003).

За возникновение ЦМС отвечают мутации в митохондриальном геноме, часто с образованием химерных генов, затрагивающие субъединицы АТФ-синтазы (atp), компоненты дыхательной цепи (nad, cox), рибосомальную РНК (rrn26) и белки (rps12), т-РНК или просто orf с неизвестной функцией. В качестве восстановителей фертильности выступают ядерные гены, инактивирующие часть генома митохондрии, влияющего на экспрессию ЦМС локуса, посттрансляционную регуляцию, РНК редактирование, а также элиминацию конечного продукта (Danilenko, Davydenko, 2003, Anisimova, Gavrilova, 2012). По фенотипическому проявлению мужская стерильность может быть (1) спорогенной, когда пыльца не формируется; (2) структурной, при которой модифицированные органы цветка не позволяют ему самоопыляться, здесь могут (2a) изменяться соотношения размеров, или быть (2b) гомеозисные превращения тычинок в пестилоиды петалоиды или карпеллы; (3) функциональной, когда пыльца формируется, но пыльники не раскрываются (Hanson, Bentolila, 2004, Kumar, 2013). Большинство из источников ЦМС льна имеет закрытый (или полузакрытый) тип цветения, деформированные тычиночные нити, желтые щуплые пыльники и какие-либо отклонения от «дикого типа» (голубой) окраски цветка. Это показывает влияние генома митохондрий на проявление окраски и формы цветка или предпочтение проявления ЦМС в цветках не «дикого типа». У ЦМС форм петунии, табака и подсолнечника также часто встречаются деформированные тычинки, у табака бывает трубчатый цветок (Anashhenko, 1968, Baranova et al., 2015, Hanson, Bentolila, 2004). ЦМС у льна была описана за 10 лет до ее официального открытия у кукурузы (Bateson, Gairdner, 1921, Rhoades, 1931, Khadzhinov, 1935 by Anisimova, Gavrilova, 2012). Основные работы по изучению восстановления фертильности проводились в 50-70-х годах прошлого века (Rykova, 1979). Создание гетерозисных гибридов в то время оказалось не рентабельным, так как лен имеет малую площадь питания и для их получения необходимо иметь много семян ЦМС линии. Большинство ЦМС линий со временем было утеряно. Сейчас интерес к таким линиям может возникнуть вновь, так как к сортам льна предъявляются иные, чем ранее требования.

У льна известно около пяти типов ЦМС, большинство из которых затрагивают окраску и форму цветков. Первый тип описан в скрещиваниях стелющегося льна, выщепившегося из образца L. grandiflorum Desf. (Bateson, Gairdner, 1921, Gairdner, 1929) или L. floccosum L. (Gajewski, 1937 by Rykova, 1979). Стерильные гибриды имели полусвернутый цветок с изогнутыми тычиночными нитями и более или менее атрофированными пыльниками. В скрещиваниях оба родителя и $\mathrm{F}_{1}$ были мужски фертильны. Стерильность части $\mathrm{F}_{2}$ обуславливало сочетание цитоплазмы от потомка дикого вида и гомозиготизация по гену $m$, полученному от отцовской формы (Gairdner, 1929).

Другой тип ЦМС найден в США, независимо у трех сортов 'Marine 96', 'Redwood 137', 'Normal 126' и изучался одновременно. В качестве плейотропного эффекта эта ЦМС обуславливает трубчатый венчик с мелкими лепестками. Материнские линии уже мужскистерильны (Dubey, Singh, 1965, 1966; Kumar, Singh, 1970, 1972). Восстановителями фертильности здесь служат четыре аллеля гена $M s-M s$ (полная фертильность) $>M s_{2}$ (он же $P f_{2}$, не полное восстановление фертильности)> $M s_{1}$ (он же $P f_{l}$, еще более слабое восстановление фертильности) (Kumar, Singh, 1970, 1972), $M s \simeq M s_{3}$ (Comstock, 1965, 1970). Возможно, этот тип ЦМС не однороден, так как, несмотря на одинаковую форму цветка, один источник ЦМС отличается от двух других по проявлению на уровне формирования пыльцы (Dubey, Singh, 1965). 
Третий тип ЦМС описан у формы из Палестины (к-1991) с бледно-голубым (почти белым) венчиком, оранжевыми фертильными пыльниками и светло-коричневыми семенами (Rogash, 1968 by Rykova, 1979), на его основе созданы две линии ЦМС Светоч 1560 и Светоч 1561, также с фертильными цветками. Стерильность и реципрокные различия проявляются во втором поколении от скрещивания каждого из них с другими образцами. Для них удалось подобрать образец, при скрещивании с которым образовывались цветки с нередуцированными лепестками, но стерильными пыльниками, а также формы, при гибридизации с которыми получаются растения с полуоткрытыми цветками и стерильной пыльцой, или с рыльцами, выходящими наружу из стерильного цветка, который сохраняется 2-3 дня (Marchenkov, 1979; Marchenkov, 1975, 1977 by Rykova, 1979; Marchenkov, 1979). Таким образом, в этом случае форма цветка и его стерильность имеют разную генетическую основу. Светоч 1560 всегда однороден, а из Светоч 1561 спонтанно выщепляются стерильные формы, которые имеют трубчатый, редуцированный венчик и закрытый тип цветения, к последним не удалось подобрать восстановителей фертильности (Marchenkov, 1979).

Четвертый тип ЦМС получен из сорта 'Redwood' и в качестве плейотропного эффекта с варьирующей экспрессивностью имел закрытый тип цветения. Пыльники у этих растений белые, крупные, сморщенные, а пыльца не образуется (Sorochinskaya, Galkin, 1977). Возможно, он идентичен второму типу, так как был получен из сорта льна того же названия.

Пятый тип выделен в популяции L. nervosum Waldst. \& Kit., из Франции, расщепляющейся как по окраске, так и по размеру и форме цветков (Rykova, 1979).

Следующие типы ЦМС (или генной мужской стерильности?) были изучены и (или) получены с помощью методов обратной генетики. Z. Нui с соавторами (Hui et al., 2010) на основе гомологии с геном $M s 2$ Arabidopsis thaliana клонировали ген MS2-F у линии с доминантной генной мужской стерильностью. Но не было показано с по- мощью классического генетического анализа какого-либо расщепления по фертильности у льна. Интересно, что продукт гена $M S 2$ - редуктаза жирных кислот локализован в пластидах и нужен для развития оболочки пыльцы (Chen et al., 2011). S. Kumar c соавторами (Kumar et al., 2013) при скрещивании двух фертильных образцов 'Double Low' и 'McDuff' получили расщепление по стерильности пыльцы, которое не соответствовало Менделевскому. Стерильность контролировалась температурочувствительным геном LuWD40-1 (из сорта 'McDuff'), последовательность которого была гомологична на $89 \%$ гену MS2-F (Hui et al., 2010 by Kumar et al., 2013). После агробактериальной трансформации этим геном сорта 'Prairie Grande', трансформанты с его сверхэкспрессией имели закрытую форму цветка, редуцированные стерильные пыльники на изогнутых тычиночных нитях (Kumar et al., 2013). Исторически сложилось, что у льна гены восстановители фертильности описывались как альтернативные аллели генов мужской стерильности, т. е. вместо принятого позже на других объектах символа «RF» использовался «m» или «ms» (Gairdner, 1929; Comstock, Ford, 1968; Comstock, 1970, Rykova, 1979). Может быть, тому способствовало и отсутствие у льна корректно описанной генной мужской стерильности. Это не мешало авторам определять аллели генов $M s$ как в восстановители фертильности. В нашей работе мы приводим название генов в соответствии с общепринятой терминологией, добавляя в конце аббревиатуры гена символ $\mathrm{T}$ для генов, контролирующих трубчатые (RFT - Restore Fertility of Male Sterility of Tubular flower) или О открытые (RFO - Restore Fertility of Male Sterility of Open flower) мужкистерильные цветки.

\section{Материалы и методы}

Работу проводили в 2006-2016 гг. на полях научно-производственной базы «Пушкинские и Павловские лаборатории ВИР» (Санкт-Петербург). В скрещивания включали линии шестого поколения инбридинга, созданные в отделе генетических ресурсов масличных и прядильных культур ВИР. 
Для генетического анализа проводили реципрокные скрещивания, в котором использовали линии, приведенные в таблице 1. В качестве источников ЦМС использованы три линии, которые имеют $\mathrm{Cyt}^{\mathrm{s} 1} \mathrm{Cyt}^{\mathrm{s} 2}$ и $\mathrm{Cyt}^{\mathrm{s} 3}$ типы цитоплазмы. Первая, гк-204 линия 1 выделена из к-7091 (DTV 7381, Франция, INRA), обладает открытым цветком с укороченными изогнутыми тычиночными нитями и стерильными, практически без пыльцы, пыльниками. В результате многочисленных отборов и инцухта у нее удалось добиться стабильного завязывания небольшого количества семян при самоопылении в конце вегетационного периода.
В процессе создания этой линии отмечено, что в холодную, пасмурную и влажную погоду ее цветки чаще имеют пыльники с пыльцой, чем в сухую и солнечную. Благоприятное влияние на образование семян играет выращивание линии под изолятором. То есть, для ее поддержания не нужен закрепитель ЦМС и нет необходимости использовать принудительное опыление. С другой стороны, это накладывает некоторое ограничение при разделении стерильных и фертильных гибридов, которое легко преодолевается с использованием современных математических методов.

\section{Таблица 1. Характеристика линий генетической коллекции льна ВИР, различающихся по фертильности пыльцы}

Table 1. Characteristics of the lines from the VIR flax genetic collection differing in pollen fertility

\begin{tabular}{|c|c|c|c|c|c|}
\hline \multirow[b]{2}{*}{ Линия } & \multirow[b]{2}{*}{ Родословная } & \multirow{2}{*}{$\begin{array}{c}\text { Генотип и } \\
\text { цитотип }\end{array}$} & \multirow{2}{*}{\begin{tabular}{|c|} 
Деформация \\
тычиночных \\
нитей
\end{tabular}} & \multicolumn{2}{|c|}{ Пыльники } \\
\hline & & & & окраска & $\begin{array}{l}\text { фертиль- } \\
\text { ность }\end{array}$ \\
\hline 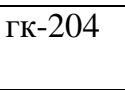 & $\begin{array}{l}\text { л-1 из к-7091 (DTV 7381, Фран- } \\
\text { ция) }\end{array}$ & $\mathrm{Cyt}^{\mathrm{s} 1}$, rfo6 & есть & желтая & $\begin{array}{c}\text { почти сте- } \\
\text { рильные }\end{array}$ \\
\hline гк-208 & $\begin{array}{l}\text { л-1 из к-7947 (Pale Blue Crimped, } \\
\text { США) }\end{array}$ & $\mathrm{Cyt}^{\mathrm{s} 2}, \mathrm{RFO6}$ & нет & « & $\begin{array}{l}\text { фертиль- } \\
\text { ные }\end{array}$ \\
\hline гк-188 & л-3 из к-3002 (Индия, Pusa Bihar) & $\mathrm{Cyt}^{\mathrm{s} 3}, r f t 5-2 ?$ & $\ll$ & $\ll$ & $\ll$ \\
\hline гК-2 & $\begin{array}{l}\text { л-1 из к-48 (селекции Альтгаузена, } \\
\text { Россия) }\end{array}$ & $\begin{array}{l}\text { rfo6 RFT4- } \\
\text { IRFT4-2 }\end{array}$ & « & голубая & « \\
\hline$\overline{\Gamma \kappa-53}$ & $\begin{array}{l}\text { л-1-4 из к-1044 (Витебский кряж, } \\
\text { Беларусь) }\end{array}$ & $\mathrm{Cyt}^{\mathrm{f}}, r f t 3-2$ & « & \begin{tabular}{|c|} 
светло- \\
оранжевая \\
\end{tabular} & $\ll$ \\
\hline гк-129 & $\begin{array}{l}\text { л-2 из к-6392 (Bolley Golden, } \\
\text { США) }\end{array}$ & $\mathrm{Cyt}^{\mathrm{f}}, r f t 5 ?$ & « & « & « \\
\hline гк-458 & $\begin{array}{l}\text { л-1 из к-7776 (восстановитель } \\
\text { фертильности,Россия,ВНИИМК) }\end{array}$ & $\begin{array}{l}\mathrm{Cyt}^{\mathrm{f}}, \text { RFO } \\
\quad \text { RFO9 }\end{array}$ & « & « & « \\
\hline гК-255 & $\begin{array}{l}\text { л-3 (л-1-1 к-6272 × л-1 к-6815), } \\
\text { Россия, ВИР }\end{array}$ & $\mathrm{Cyt}^{\mathrm{f}}$, rfo6, ? & « & « & « \\
\hline гк-176 & $\begin{array}{l}\text { Л-1 (л-1 к-6815× л-4 к-5896), Рос- } \\
\text { сия, ВИР }\end{array}$ & $\begin{array}{c}\mathrm{Cyt}^{\mathrm{f}}, \boldsymbol{r f o 7}, \boldsymbol{r f t 3 -} \\
6, \text { rft3-7 } \\
\end{array}$ & « & « & « \\
\hline гк-103 & $\begin{array}{l}\text { л-4 из к-5896 (Lin 225, } \\
\text { Нидерланды) }\end{array}$ & \begin{tabular}{|c|}
$\mathrm{Cyt}^{\mathrm{f}}, r f o 7, r f t 5-$ \\
2
\end{tabular} & « & желтая & « \\
\hline гк-159 & л-1-1 из к-7659 (Bionda, Германия) & $\begin{array}{c}\mathrm{Cyt}^{\mathrm{f}}, r f t 3-3, \\
\text { rfo6? }\end{array}$ & « & голубая & « \\
\hline гк-210 & $\begin{array}{l}\text { Л-1 из и-588294 (Б-125, Упитская } \\
\text { оп.ст., Литва) }\end{array}$ & $\begin{array}{l}\mathrm{Cyt}^{\mathrm{f}}, r f o 6-3, \\
\text { rft6, rft7 }\end{array}$ & « & голубая & « \\
\hline гк-124 & $\begin{array}{l}\text { л-1 из к-6284 (Stormont Motley, } \\
\text { Сев.Ирландия) }\end{array}$ & $\begin{array}{l}\mathrm{Cyt}^{\mathrm{f}}, r f t 3-7 \\
\text { rfo6-2 }\end{array}$ & « & серая & « \\
\hline гк-368 & $\begin{array}{l}\text { л-1 (л-3 к-3178 × л-1 к-6284), Рос- } \\
\text { сия, ВИР }\end{array}$ & $\begin{array}{c}\text { Cytt }^{\mathrm{f}}, \text { rfo6, } \\
\text { RFT4-3 }\end{array}$ & $\ll$ & $\begin{array}{c}\text { светло- } \\
\text { оранжевая }\end{array}$ & « \\
\hline
\end{tabular}

Другие две линии гк-208 линия 1 из к7947 ('Pale Blue Crimped', США) и гк-188 линия 3 из к-3002 (Индия, Pusa Bihar) абсолютно фертильны, так как изначально несут в своем генотипе гены восстановители фертильности, а стерильность проявлялась только в результате гибридизации с неимеющими нужной аллели линиями.

В качестве отцовских форм использовали линии различного экологогеографического происхождения, среди них предпочтение отдавалось несущим ген розовой окраски цветка, так как по предвари- 
тельным данным он мог быть сцеплен с геном восстановителем фертильности (Comstock, 1970).

Растения $\mathrm{F}_{1}$ выращивали под изолятором и обмолачивали индивидуально. Полученные гибриды второго поколения выращивали рядом с родительскими формами и при наличии семян с $\mathrm{F}_{1}$. В анализе использовали индивидуальное этикетирование растений, что позволяло учитывать несколько цветков, распустившихся в разное время. Определение стерильных и фертильных форм у гибридов осуществляли во время цветения по первому и второму цветкам, а при несовпадении фенотипов по следующим. Как правило, стерильность пыльников сопровождалась изогнутостью и (или) укороченностью тычиночных нитей. После созревания подсчитывалось число семян в коробочке I порядка и четырех - II порядка, а также число незавязавшихся из них. В большинстве скрещиваний оконча- тельное разделение на фенотипические классы по фертильности/стерильности проводили с применением дискириминантного анализа при помощи программы Statistica 7.0. (Nasledov, 2012, StatSoft, Inc., 2013). B качестве обучающей выборки (центр каждого класса) использовали родительские линии, гибриды второго поколения противоположного направления скрещивания. Гибрид относили к тому классу, где значение функции классификации максимально. Для примера, в работе подробно обсуждается дискриминантный анализ $\mathrm{F}_{2}$ ф гк-204 × фгк-53. В статье приняты следующие сокращения для описания стерильности и формы цветка: ферт. - фертильный; стер. стерильный; откр. - открытый; труб. - стерильный трубчатый. Открытые цветки могут быть как фертильными, так и стерильными, а трубчатые - всегда стерильны, поэтому при необходимости уточняется форма стерильных цветков.

\section{Таблица 2. Завязываемость коробочек и семян у родительских линий и их гибридов, различающихся по фертильности пыльцы \\ Table 2. Boll and seed formation in parental lines and their hybrids differing in pollen fertility}

\begin{tabular}{|c|c|c|c|c|c|c|c|c|c|c|c|c|c|c|c|}
\hline \multirow{4}{*}{$\begin{array}{c}\text { Скрещи- } \\
\text { вание }\end{array}$} & \multirow{4}{*}{ Год } & \multicolumn{7}{|c|}{ Число семян в коробочке, шт. } & \multicolumn{7}{|c|}{ Не завязавшиеся коробочки, \% } \\
\hline & & \multirow{3}{*}{$\begin{array}{l}\mathrm{P}_{1} \\
(\text { 早) }\end{array}$} & \multirow{3}{*}{$\begin{array}{l}\mathrm{P}_{2} \\
\left(\jmath^{\lambda}\right)\end{array}$} & \multirow[b]{3}{*}{$\mathrm{F}_{1}$} & & $\times \mathrm{P}_{2}$ & & $\mathrm{P}_{2} \times \mathrm{P}_{1}$ & \multirow{3}{*}{$\begin{array}{c}\mathrm{P}_{1} \\
(q)\end{array}$} & \multirow{3}{*}{$\begin{array}{l}\mathrm{P}_{2} \\
(\precsim)\end{array}$} & \multirow[b]{3}{*}{$\mathrm{F}_{1}$} & \multicolumn{3}{|c|}{$\mathrm{P}_{1} \times \mathrm{P}_{2}$} & $\mathrm{P}_{2} \times \mathrm{P}_{1}$ \\
\hline & & & & & \multicolumn{4}{|c|}{ фенотипы $\mathrm{F}_{2}$} & & & & \multicolumn{4}{|c|}{ фенотипы $\mathrm{F}_{2}$} \\
\hline & & & & & $\begin{array}{l}\text { откр. } \\
\text { ферт. }\end{array}$ & $\begin{array}{l}\text { откр. } \\
\text { стер. }\end{array}$ & $\begin{array}{l}\text { труб. } \\
\text { стер. }\end{array}$ & $\begin{array}{l}\text { откр. } \\
\text { ферт. }\end{array}$ & & & & $\begin{array}{l}\text { откр. } \\
\text { ферт. }\end{array}$ & $\begin{array}{l}\text { откр. } \\
\text { стер. }\end{array}$ & $\begin{array}{l}\text { труб } \\
\text { стер. }\end{array}$ & $\begin{array}{l}\text { откр. } \\
\text { ферт. }\end{array}$ \\
\hline ГК-204×ГК-53 & 2013 & $27 \pm 0,2$ & $7,3 \pm 0,3$ & $4,6+0,3$ & $6,8+0,2$ & $2, \pm+0,4$ & $0,2 \pm 0,3$ & $6,7 \pm 0,1$ & $12+3$ & $4 \pm 4$ & нд & $4+2$ & $43+7$ & $70 \pm 6$ & $2 \pm 1$ \\
\hline $\begin{array}{l}\text { ГК-204×ГК- } \\
159\end{array}$ & 2013 & $27 \pm 0,2$ & $6,1 \pm 0,6$ & $4,6 \pm 0,7$ & $4,2+0,3$ & $0,8+0,2$ & $0,1 \pm 0,1$ & $6,2 \pm 0,3$ & $12+3$ & $2 \pm 2$ & нд & $23+5$ & $70+4$ & $98+2$ & $5+2$ \\
\hline $\begin{array}{l}\text { ГК- } 204 \times \text { ГК- } \\
368\end{array}$ & 2013 & $2,7 \pm 0,2$ & $85 \pm 0,2$ & 1,3 & 6 & $0,6 \pm 0,2$ & $0,8 \pm 0,4$ & $69 \pm 0,6$ & $12 \pm 3$ & $0+0$ & нд & 20 & $73 \underline{8}$ & $84 \pm 6$ & $3+3$ \\
\hline $\begin{array}{l}\text { ГК-204×ГК- } \\
255\end{array}$ & 2013 & $27 \pm 0,2$ & $8,0 \pm 0,3$ & $1,2 \pm 0,4$ & 9 & $0,5 \pm 0,5$ & $0 \pm 0$ & нд & $12 \pm 3$ & $2 \pm 2$ & нд & 0 & $90 \pm 10$ & $95 \pm 5$ & нд, \\
\hline $\begin{array}{l}\text { ГК-204×ГК- } \\
176\end{array}$ & 2013 & $27 \pm 0,2$ & $7,1 \pm 0,4$ & $4,5 \pm 0,3$ & $5,3+0,2$ & $1,6 \pm 0,2$ & $0,6 \pm 0,1$ & $5,8 \pm 0,2$ & $12 \pm 3$ & $0 \pm 0$ & $0 \pm 0$ & $4 \pm 1$ & $32 \pm 4$ & $62 \pm 5$ & $1 \pm 1$ \\
\hline $\begin{array}{l}\text { ГК-204×ГК- } \\
129\end{array}$ & 2013 & $27 \pm 0,2$ & $5,8 \pm 0,2$ & $5,7 \pm 0,5$ & $5, \pm 0,2$ & $1,5 \pm 0,2$ & $0,5 \pm 0,3$ & $5,7 \pm 0,2$ & $12 \pm 3$ & $11 \pm 2$ & $0 \pm 0$ & $10 \pm 2$ & $47 \pm 8$ & $50+29$ & $2 \pm 1$ \\
\hline $\begin{array}{l}\text { ГК-204×ГК- } \\
458\end{array}$ & 2014 & $2,0 \pm 0,3$ & $8,8 \pm 0,3$ & $6,8 \pm 0,2$ & $7, \pm \pm 0,1$ & $3,1+0,3$ & нет & $7,2 \pm 0,3$ & $38+6$ & $0 \underline{+0}$ & нд & $1 \pm 0$ & $16 \pm 5$ & нет & $0+0$ \\
\hline $\begin{array}{l}\text { ГК- } 204 \times \Gamma \text { ГК- } \\
208\end{array}$ & 2016 & $2,7 \pm 0,3$ & $6,8 \pm 0,3$ & $4,6 \pm 0,8$ & $5,6 \pm 0,1$ & $3,1 \pm 0,2$ & нет & $6,1 \pm 0,2$ & $27 \pm 5$ & $10 \pm 3$ & $15 \pm 3$ & $12 \pm 1$ & $33 \pm 3$ & нет & $6 \pm 2$ \\
\hline $\begin{array}{l}\text { ГК-208×ГК- } \\
124\end{array}$ & 2014 & $8,8 \pm 0,1$ & $8,1 \pm 0,2$ & нд, & $8,0+0,1$ & $3,1 \pm 0,3$ & $0,5+0,2$ & $8,5 \pm 0,1$ & $\mathrm{O}_{ \pm 0}$ & $0+0$ & нд & $0,9+0,4$ & $26 \pm 5$ & $78+4$ & $0,6 \pm 0,3$ \\
\hline $\begin{array}{l}\text { ГК- } 208 \times \text { ГК- } \\
210 \\
\end{array}$ & 2016 & $7,7 \pm 0,4$ & $5,3 \pm 0,5$ & нд & $5, \pm+0,3$ & $5,4 \pm 0,6$ & $5,5 \pm 0,5$ & $5,7 \pm 0,4$ & $1 \pm 1$ & $3 \pm 2$ & нд & $12 \pm 3$ & $13 \pm 6$ & $0 \pm 0$ & $6 \pm 2$ \\
\hline $\begin{array}{l}\text { ГК-188× ГК- } \\
103\end{array}$ & 2016 & $4,2 \pm 0,5$ & $6,1 \pm 1,0$ & нд, & $4,8+0,2$ & $3,4+0,5$ & $1,8 \pm 0,5$ & $6,0 \pm 0,3$ & $2 \pm 2$ & $4 \pm 4$ & нд & $14 \pm 2$ & $24 \pm 5$ & $44+12$ & $9 \underline{9} 2$ \\
\hline
\end{tabular}

Примечание: н.д. - нет данных 
Таблица 3. Реципрокные различия по восстановлению фертильности пыльцы у $F_{1}$ от скрещивания гк-204 с другими линиями

Table 3. Reciprocal differences of pollen fertility restoration in $F_{1}$ from the crosses of gc-204 with other lines

\begin{tabular}{|c|c|c|c|c|}
\hline \multirow[t]{2}{*}{$\begin{array}{l}\text { Направление } \\
\text { скрещивания }\end{array}$} & \multirow[t]{2}{*}{$\begin{array}{c}\text { Год изу- } \\
\text { чения }\end{array}$} & \multicolumn{2}{|c|}{$\begin{array}{c}\text { Число семян в коробоч- } \\
\text { ке }\end{array}$} & \multirow{2}{*}{$\begin{array}{c}\text { Стерильность цветков и завязывае- } \\
\text { мость коробочек }\end{array}$} \\
\hline & & среднее & $\min -\max$ & \\
\hline $\begin{array}{l}\text { гК-204 × гк-53 } \\
\text { гК-53× гК-204 }\end{array}$ & 2012 & 4,6 & $\begin{array}{l}4,4-5,2 \\
4,4-5,4\end{array}$ & $\begin{array}{c}\text { Фертильны, иногда есть стерильные } \\
\text { цветки. } \\
\text { Все фертильны. }\end{array}$ \\
\hline $\begin{array}{r}\text { гК-204 × гК-159 } \\
\text { гК-159 × гК-204 } \\
\end{array}$ & 2012 & $\begin{array}{l}4,6 \\
5,4\end{array}$ & $\begin{array}{l}3,5-5,9 \\
5,2-5,6\end{array}$ & $\begin{array}{c}\text { Стерильны, много не завязавшихся } \\
\text { коробочек, есть только коробочки } \\
\text { после вторичного цветения. } \\
\text { Все фертильны. }\end{array}$ \\
\hline $\begin{array}{l}\text { гК-204 × гК-2 } \\
\text { гК-2 } \times \text { гК- } 204 \\
\end{array}$ & $\begin{array}{l}2004, \\
2010\end{array}$ & & & $\begin{array}{c}\text { Стерильны, много не завязавшихся } \\
\text { коробочек, завязались только еди- } \\
\text { ничные коробочки. } \\
\text { Все фертильны. }\end{array}$ \\
\hline $\begin{array}{r}\text { гК-204 × гК-368 } \\
\text { гК-368 } \times \text { гК-204 } \\
\end{array}$ & 2012 & 4,3 & $3,8-4,8$ & $\begin{array}{c}\text { Стерильны, много не завязавшихся } \\
\text { коробочек, есть только коробочки } \\
\text { после вторичного цветения. } \\
\text { Все фертильны. } \\
\end{array}$ \\
\hline гк-204 × гк-255 & 2012 & 1,2 & $0,8-2,3$ & $\begin{array}{c}\text { Стерильны, много не завязавшихся } \\
\text { коробочек. }\end{array}$ \\
\hline $\begin{array}{r}\text { гК-204 × гк-176 } \\
\text { гК-176 × гК-204 }\end{array}$ & 2012 & $\begin{array}{l}3,9 \\
4,3\end{array}$ & $\begin{array}{l}2,2-4,9 \\
3,5-5,0\end{array}$ & $\begin{array}{c}\text { Стерильные и фертильные цветки, } \\
\text { хорошая завязываемость коробочек } \\
\text { Все фертильны. }\end{array}$ \\
\hline $\begin{array}{l}г К-204 \times \text { гК-129 } \\
\text { ГК-129 × гК-204 }\end{array}$ & 2012 & $\begin{array}{l}5,2 \\
3,8\end{array}$ & $\begin{array}{c}4,3-5,8 \\
3,8\end{array}$ & $\begin{array}{c}\text { Все фертильны. } \\
\text { « }\end{array}$ \\
\hline $\begin{array}{l}\text { гК-204 × гК-458 } \\
\text { гК-458 } \times \text { гК- } 204 \\
\end{array}$ & 2013 & $\begin{array}{l}7,3 \\
6,8 \\
\end{array}$ & $\begin{array}{l}7,2-7,5 \\
6,4-7,3 \\
\end{array}$ & « \\
\hline гк-204 × гк-208 & $\begin{array}{l}2015 \\
2016 \\
\end{array}$ & $\begin{array}{l}7,8 \\
4,6\end{array}$ & $\begin{array}{l}7,2-8,4 \\
5,0-8,2\end{array}$ & « \\
\hline гк-208 × гк-204 & $\begin{array}{l}2015 \\
2016\end{array}$ & $\begin{array}{l}7,9 \\
5,5\end{array}$ & $\begin{array}{l}6,8-9,0 \\
5,5-9,0\end{array}$ & « \\
\hline
\end{tabular}

\section{Результаты и обсуждение}

B $\mathrm{F}_{1}$ от скрещивания гк-204 с линиями различного происхождения наблюдались реципрокные различия. В скрещиваниях гк204 (†) с гк-2, 53, 159, 176, 255, 368 у растений $\mathrm{F}_{1}$ были стерильные пыльники, тогда как в противоположном направлении все цветки - всегда фертильны. У стерильных гибридов продлевалось время цветения, за счет образования большего количества цветков. Стерильность имела варьирующую экспрессивность, степень проявления которой отличалась и при использовании различных отцовских форм. У $\mathrm{F}_{1}$ Фгк-204 × 今̄гк-53 и 176 преобладали фертильные цветки, и была хорошая завязываемость коробочек, с ठึгк-159 и 368 завязались только коробочки после вторичного цвете- ния, а с §ิгк-2 и 255 завязались только единичные коробочки с 1-2 семенами в каждой. У $F_{1}$ гк-204 × гк-208, а также с линией восстановителем фертильности (гк-458) и родственной ей линии (гк-129) реципрокных различий не наблюдалось (табл. 2, 3).

Все гибриды от скрещивания 9 гк-53 $\times$ ๙ิ гк-204 были фертильны, тогда как в обратном направлении было три класса расщепления по фертильности и форме венчика: фертильные открытые, стерильные открытые, стерильные трубчатые. Все гибриды с трубчатыми цветками всегда имели изогнутые тычиночные нити и стерильную пыльцу, тогда как у растений с открытым цветением была варьирующая экспрессивность, то есть не все цветки на растении имели стерильные пыльники (см. табл. 2, 
3). Окончательно разделение на фенотипические классы проводили при помощи дискириминантного анализа. Значение коэффициента $\lambda$ Уилкса $=0,39468$; approx. F (2,
$150)=115,03($ теор. $=3,90)$. Для обучающей выборки была получена корректная классификация на $92,8 \%$ (табл. 4).

Таблица 4. Определение стерильности пыльцы по завязываемости коробочек и семян у $\mathrm{F}_{2}$ гк-204 × гк-53

Table 4. Determination of pollen sterility on the basis of boll and seed formation in $F_{2}$ of the cross gc-204 $\times$ gc- 53

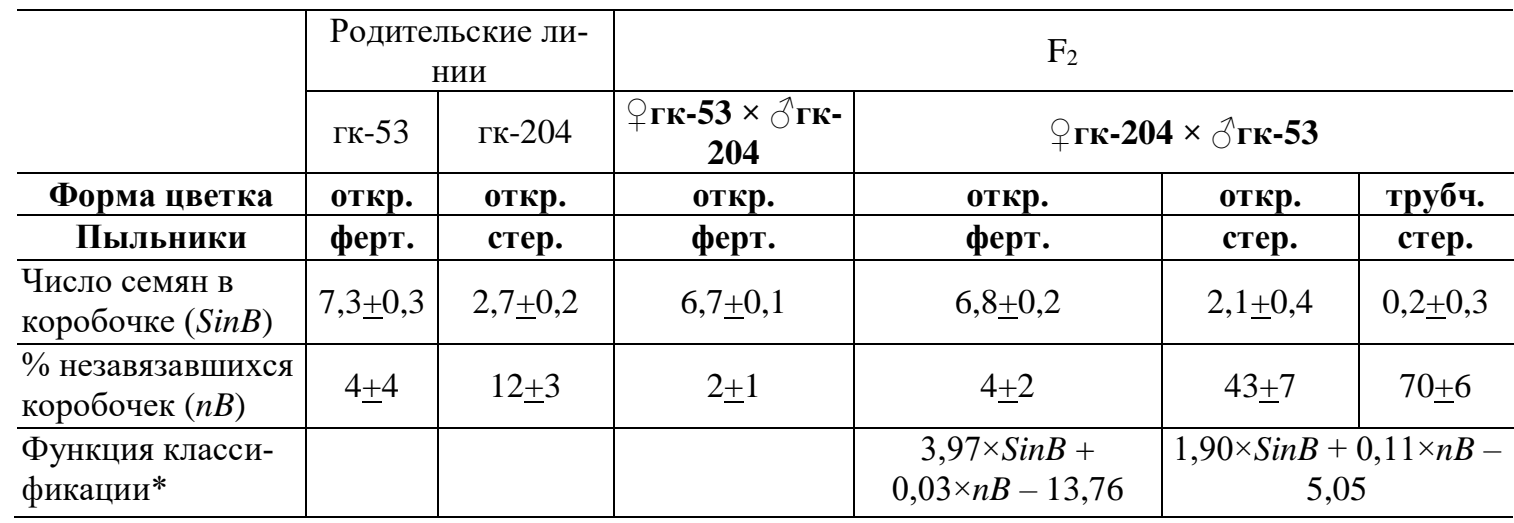

*Фенотипы определяли по результатам дискриминационного анализа.

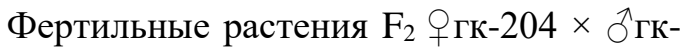
53 статистически не отличались от гк-53 и $\mathrm{F}_{2}$ обратного направления скрещивания по числу семян в коробочке и количеству незавязавшихся коробочек. Гибриды с открытыми стерильными цветками при свободном цветении имели по сравнению с гк-204 незначительно меньше семян в коробочке и больше незавязавшихся коробочек. Гибриды с трубчатыми цветками практически не завязали плодов, а в единичных коробочках часто не было семян (см. табл. 2).

После окончательного определения фе-

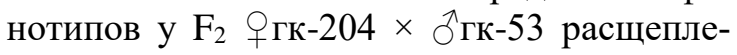
ние соответствовало дигенному - 9 ферт.: 3 стер.: 4 трубч., где ген $r f o 6$, позволяет проявиться стерильности, не влияя на открытость цветка, тогда как ген rft3-2 помимо мужской стерильности приводит к деформации венчика (табл. 5).

В следующей группе скрещиваний († гк204 с §ٓгк-159, 2, 368, 255) наличие фертильных гибридов может быть вызвано неполной пенетрантностью гена rfo6 у гомозигот. В F 2 фгк-204 × ภ̄гк-159 наблюдалось расщепление 18 ферт.: 55 стер.: 18 трубч. (см. табл. 5). Для объяснения могут быть выдвинуты две гипотезы. $\mathrm{H}_{01}$ (3 стер., откр: 1 стер., трубч.) предполагает что 18 стерильных растений были ошибочно описаны как фертильные. Тогда оба родителя несут аллельные гены $r f o 6$, а гк-159 гомозиготна по гену rft3-3, обуславливающему трубча- тые цветки. $\mathrm{H}_{02}$ (3 ферт.: 9 стер.: 4 трубч.) предполагает, что существует рецессивный ген восстановитель фертильности, который не работает у трубчатых цветков, гомозигот по гену rft3-3. В пользу первой гипотезы говорит небольшое число семян в коробочках фертильных гибридов (см. табл. 2), а также появление в последующих поколениях у стерильных гибридов единичных фертильных цветков.

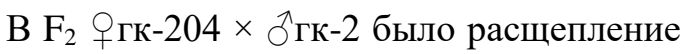
14 стер., откр.: 12 стер., трубч. (см. табл. 5). Обе линии гомозиготны по гену $r f o 6$, также можно обсуждать дигенное наследование трубчатости (9 к 7 с генами $r f t 3-4, r f t 3-5$ или 7 к 9 с генами MST4-1 MST4-2).

В $\mathrm{F}_{2}$ Фгк-204 × §гк-368 наблюдалось расщепление 8 ферт. : 9 стер. : 33 трубч. (см. табл. 5). Его может объяснять несколько гипотез. $\mathrm{H}_{01}$ (1 стер. откр.: 3 стер., трубч.) предполагает, что 8 стерильных растений были ошибочно описаны как фертильные. Тогда оба родителя несут аллельные гены $r f o 6$, а гк-368 гомозиготна по гену RFT4-3, обуславливающему трубчатые цветки. $\mathrm{H}_{02(03)}$ [3 (4) ферт. : 4 (3) стер., откр. : 9 стер., трубч.] подразумевают существование двух доминантных генов, контролирующих образование трубчатых цветков, рецессивная аллель одного из которых дает стерильные открытые цветки, а другого фертильные. 
Таблица 5. Генетический контроль восстановления фертильности пыльцы

у F2 от скрещивания Ргк-204 с о̛гк-53, 159, 2, 368, 255, 176, 129, 458

Table 5. Genetic control of pollen fertility restoration in F2 from the crosses of Igc-204 with ơgc-53, 159, 2, 368, 255, 176, 129, 458

\begin{tabular}{|c|c|c|c|c|c|c|c|c|c|c|c|c|c|c|c|c|}
\hline \multirow{2}{*}{\multicolumn{4}{|c|}{ 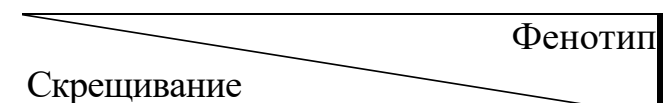 }} & \multicolumn{3}{|c|}{ Цветок/пыльники } & \multirow{3}{*}{$\sum$} & \multirow{3}{*}{$\chi_{\text {пр }}^{2} *$} & \multicolumn{2}{|c|}{ Пыльники } & \multirow{3}{*}{$\Sigma$} & \multirow{3}{*}{$\chi_{\text {пр. }}^{2}$} & \multicolumn{2}{|c|}{ Цветок } & \multirow{3}{*}{$\sum$} & \multirow{3}{*}{$\chi_{\text {пр. }}^{2}$} \\
\hline & & & & \multirow{2}{*}{$\begin{array}{l}\text { откр. } \\
\text { ферт. }\end{array}$} & \multirow{2}{*}{$\begin{array}{l}\text { откр. } \\
\text { стер. }\end{array}$} & \multirow{2}{*}{$\begin{array}{l}\text { труб. } \\
\text { стер. }\end{array}$} & & & & & & & & & & \\
\hline линии & гены & Год & $\mathrm{H}_{0}$ & & & & & & ферт. & стер. & & & откр. & труо. & & \\
\hline $\begin{array}{l}\text { гК-204× } \\
\text { гК-53 }\end{array}$ & $\begin{array}{l}\text { rfo6 } \\
\text { rft3-2 }\end{array}$ & 2013 & $\begin{array}{l}\Pi p . \\
\mathbf{H}_{\mathbf{0}}\end{array}$ & $\begin{array}{c}71 \\
9\end{array}$ & $\begin{array}{c}27 \\
\mathbf{3}\end{array}$ & $\begin{array}{c}26 \\
4\end{array}$ & $\begin{array}{c}124 \\
\mathbf{1 6}\end{array}$ & 1,43 & $\begin{array}{c}71 \\
9\end{array}$ & $\begin{array}{c}53 \\
7\end{array}$ & $\begin{array}{c}124 \\
16\end{array}$ & 0,05 & $\begin{array}{c}98 \\
\mathbf{3}\end{array}$ & $\begin{array}{c}26 \\
\mathbf{1}\end{array}$ & $\begin{array}{c}124 \\
4\end{array}$ & 1,08 \\
\hline $\begin{array}{l}\text { гк-204× } \\
\text { гК-159 }\end{array}$ & \begin{tabular}{|l|} 
rfo6 \\
rft3-3 \\
rfo6?
\end{tabular} & 2013 & $\begin{array}{l}\text { пр. } \\
\mathbf{H}_{01} \\
\mathbf{H}_{02}\end{array}$ & $\begin{array}{c}18 \\
\text { нет } \\
\mathbf{3}\end{array}$ & $\begin{array}{c}55 \\
3 \\
9\end{array}$ & $\begin{array}{c}18 \\
\mathbf{1} \\
\mathbf{4}\end{array}$ & $\begin{array}{c}91 \\
4 \\
\mathbf{1 6}\end{array}$ & $\begin{array}{l}1,32 \\
1,33\end{array}$ & $\begin{array}{c}18 \\
3\end{array}$ & $\begin{array}{c}73 \\
\text { един. } \\
\mathbf{1 3}\end{array}$ & $\begin{array}{l}91 \\
16\end{array}$ & 0,06 & $\begin{array}{c}73 \\
\mathbf{3} \\
\mathbf{3}\end{array}$ & $\begin{array}{c}18 \\
\mathbf{1} \\
\mathbf{1}\end{array}$ & $\begin{array}{c}91 \\
4 \\
4\end{array}$ & $\begin{array}{l}1,32 \\
1,32\end{array}$ \\
\hline $\begin{array}{l}\text { гК-204× } \\
\text { гК-2 }\end{array}$ & $\begin{array}{l}\text { rfo6 } \\
\text { rfo6 } \\
\text { RFT4-1 } \\
\text { RFT4-2 }\end{array}$ & 2011 & $\begin{array}{l}\Pi p . \\
\mathbf{H}_{01} \\
\mathbf{H}_{02} \\
\mathbf{H}_{03}\end{array}$ & нет & $\begin{array}{c}14 \\
3 \\
9 \\
7\end{array}$ & $\begin{array}{c}12 \\
\mathbf{1} \\
\mathbf{7} \\
\mathbf{9}\end{array}$ & $\begin{array}{c}26 \\
4 \\
\mathbf{1 6} \\
\mathbf{1 6}\end{array}$ & $\begin{array}{l}6,21 \\
0,06 \\
0,06\end{array}$ & & $\begin{array}{l}\text { един. } \\
\text { един. } \\
\text { един. }\end{array}$ & & & $\begin{array}{c}14 \\
3 \\
9 \\
7\end{array}$ & $\begin{array}{c}12 \\
\mathbf{1} \\
7 \\
9\end{array}$ & $\begin{array}{c}26 \\
4 \\
16 \\
16\end{array}$ & $\begin{array}{l}6,21 \\
0,06 \\
1,08\end{array}$ \\
\hline $\begin{array}{l}\text { гК-204× } \\
\text { гК-368 }\end{array}$ & $\begin{array}{l}\text { rfo6 } \\
\text { rfo6 } \\
\text { RFT4-3 }\end{array}$ & 2015 & $\begin{array}{l}\text { пр. } \\
\mathbf{H}_{01} \\
\mathbf{H}_{02} \\
\mathbf{H}_{03} \\
\mathbf{H}_{04} \\
\mathbf{H}_{05} \\
\mathbf{H}_{06}\end{array}$ & $\begin{array}{c}8 \\
\text { нет } \\
\mathbf{4} \\
\mathbf{3} \\
\text { нет } \\
\mathbf{1} \\
\mathbf{1}\end{array}$ & $\begin{array}{l}9 \\
\mathbf{1} \\
\mathbf{3} \\
\mathbf{4} \\
7 \\
\mathbf{3} \\
6\end{array}$ & $\begin{array}{c}33 \\
3 \\
9 \\
9 \\
9 \\
12 \\
9\end{array}$ & $\begin{array}{c}50 \\
4 \\
16 \\
16 \\
16 \\
16 \\
16\end{array}$ & $\begin{array}{c}2,16 \\
2,48 \\
2,03 \\
1,93 \\
8,16 \\
13,52\end{array}$ & $\begin{array}{l}8 \\
1 \\
3\end{array}$ & $\begin{array}{c}42 \\
\text { един. } \\
\mathbf{3} \\
\mathbf{1 3} \\
\text { един. } \\
\mathbf{1 5} \\
\mathbf{1 5}\end{array}$ & $\begin{array}{c}50 \\
\\
4 \\
\mathbf{1 6} \\
\\
\mathbf{1 6} \\
\mathbf{1 6}\end{array}$ & $\begin{array}{l}2,16 \\
0,25 \\
8,11 \\
8,11\end{array}$ & $\begin{array}{c}17 \\
1 \\
7 \\
7 \\
7 \\
1 \\
7\end{array}$ & $\begin{array}{l}33 \\
\mathbf{3} \\
\mathbf{9} \\
\mathbf{9} \\
\mathbf{9} \\
\mathbf{3} \\
\mathbf{9}\end{array}$ & $\begin{array}{c}50 \\
4 \\
16 \\
16 \\
16 \\
4 \\
16\end{array}$ & $\begin{array}{l}2,16 \\
1,93 \\
1,93 \\
1,93 \\
2,16 \\
1,93\end{array}$ \\
\hline & & 2013 & $\begin{array}{l}\text { пр. } \\
\mathbf{H}_{01} \\
\mathbf{H}_{02} \\
\mathbf{H}_{03} \\
\mathbf{H}_{04} \\
\mathbf{H}_{05}\end{array}$ & $\begin{array}{c}1 \\
\text { нет } \\
\mathbf{4} \\
\mathbf{3} \\
\text { нет } \\
\mathbf{1}\end{array}$ & $\begin{array}{l}6 \\
\mathbf{1} \\
\mathbf{3} \\
\mathbf{4} \\
\mathbf{7} \\
\mathbf{3}\end{array}$ & $\begin{array}{c}9 \\
3 \\
9 \\
9 \\
9 \\
12\end{array}$ & $\begin{array}{c}16 \\
4 \\
16 \\
16 \\
16 \\
16\end{array}$ & $\begin{array}{l}3,00 \\
5,25 \\
2,33 \\
0,00 \\
3,75\end{array}$ & $\begin{array}{l}1 \\
3\end{array}$ & $\begin{array}{c}15 \\
\text { един. } \\
\mathbf{3} \\
\mathbf{1 3} \\
\text { един. } \\
\mathbf{1 5}\end{array}$ & $\begin{array}{c}16 \\
\\
4 \\
16 \\
\\
16\end{array}$ & $\begin{array}{l}3,00 \\
1,64 \\
0,00\end{array}$ & $\begin{array}{l}7 \\
1 \\
7 \\
7 \\
7 \\
1\end{array}$ & $\begin{array}{l}9 \\
3 \\
9 \\
9 \\
9 \\
3\end{array}$ & $\begin{array}{c}16 \\
4 \\
16 \\
16 \\
16 \\
4\end{array}$ & $\begin{array}{l}3,00 \\
0,00 \\
0,00 \\
0,00 \\
3,00\end{array}$ \\
\hline
\end{tabular}




\begin{tabular}{|c|c|c|c|c|c|c|c|c|c|c|c|c|c|c|c|c|}
\hline & & & $\mathbf{H}_{06}$ & 1 & 6 & 9 & 16 & 0,00 & 1 & 15 & 16 & 0,00 & 7 & 9 & 16 & 0,00 \\
\hline $\begin{array}{l}\text { гк-204× } \\
\text { гк-255 }\end{array}$ & $\begin{array}{r}\text { rfo6 } \\
\text { rfo6 }\end{array} ?$ & 2013 & $\begin{array}{l}\text { пр. } \\
\mathbf{H}_{01} \\
\mathbf{H}_{02} \\
\mathbf{H}_{03} \\
\mathbf{H}_{04} \\
\mathbf{H}_{05}\end{array}$ & $\begin{array}{c}1 \\
\text { нет } \\
\mathbf{1} \\
\mathbf{4} \\
\mathbf{3} \\
\mathbf{1}\end{array}$ & $\begin{array}{l}4 \\
7 \\
6 \\
3 \\
4 \\
3\end{array}$ & $\begin{array}{c}4 \\
9 \\
9 \\
9 \\
9 \\
\mathbf{1 2}\end{array}$ & $\begin{array}{c}9 \\
16 \\
16 \\
16 \\
16 \\
16\end{array}$ & $\begin{array}{l}0,51 \\
0,68 \\
4,09 \\
1,86 \\
4,63\end{array}$ & $\begin{array}{l}\mathbf{1} \\
\mathbf{1} \\
\mathbf{3} \\
\mathbf{1}\end{array}$ & $\begin{array}{c}8 \\
\text { един. } \\
\mathbf{1 5} \\
\mathbf{3} \\
\mathbf{1 3} \\
\mathbf{1 5}\end{array}$ & $\begin{array}{c}16 \\
4 \\
16 \\
16\end{array}$ & $\begin{array}{l}0,36 \\
0,93 \\
0,34 \\
0,36\end{array}$ & $\begin{array}{l}5 \\
7 \\
7 \\
7 \\
7 \\
1\end{array}$ & $\begin{array}{l}4 \\
9 \\
9 \\
9 \\
9 \\
3\end{array}$ & $\begin{array}{c}9 \\
16 \\
16 \\
16 \\
16 \\
4\end{array}$ & $\begin{array}{l}0,51 \\
0,51 \\
0,51 \\
0,51 \\
4,48\end{array}$ \\
\hline $\begin{array}{l}\text { гК-204× } \\
\text { гК-176 }\end{array}$ & $\begin{array}{l}\text { rfo6 } \\
\text { rfo7 } \\
\text { rft3-6 }\end{array}$ & $\begin{array}{c}2013 \\
\text { семья } \\
\text { I }\end{array}$ & $\begin{array}{l}\text { пр. } \\
\mathbf{H}_{01} \\
\mathbf{H}_{02} \\
\mathbf{H}_{03} \\
\mathbf{H}_{04} \\
\mathbf{H}_{05}\end{array}$ & $\begin{array}{c}26 \\
27 \\
\mathbf{8 1} \\
\mathbf{6 3} \\
\mathbf{2 1} \\
\mathbf{9}\end{array}$ & $\begin{array}{c}18 \\
21 \\
63 \\
81 \\
27 \\
3\end{array}$ & $\begin{array}{c}20 \\
16 \\
112 \\
112 \\
16 \\
4\end{array}$ & $\begin{array}{c}64 \\
64 \\
256 \\
256 \\
64 \\
16\end{array}$ & $\begin{array}{l}1,47 \\
4,24 \\
9,21 \\
5,19 \\
6,78\end{array}$ & $\begin{array}{c}26 \\
27 \\
\mathbf{8 1} \\
\mathbf{6 3} \\
\mathbf{2 1} \\
\mathbf{9}\end{array}$ & $\begin{array}{c}38 \\
\mathbf{3 7} \\
\mathbf{1 7 5} \\
\mathbf{1 9 3} \\
\mathbf{4 3} \\
\mathbf{7}\end{array}$ & $\begin{array}{c}64 \\
64 \\
256 \\
256 \\
64 \\
16\end{array}$ & $\begin{array}{l}0,06 \\
2,39 \\
8,85 \\
1,77 \\
6,35\end{array}$ & $\begin{array}{c}44 \\
\mathbf{3} \\
\mathbf{9} \\
\mathbf{9} \\
\mathbf{3} \\
\mathbf{3}\end{array}$ & $\begin{array}{c}20 \\
\mathbf{1} \\
7 \\
7 \\
\mathbf{1} \\
\mathbf{1}\end{array}$ & $\begin{array}{c}64 \\
4 \\
16 \\
16 \\
4 \\
4\end{array}$ & $\begin{array}{l}1,33 \\
4,06 \\
4,06 \\
1,33 \\
1,33\end{array}$ \\
\hline $\begin{array}{l}\text { гк-204× } \\
\text { гк-176 }\end{array}$ & $\begin{array}{l}\text { rfo6 } \\
\text { rfo7 } \\
\text { rft3-6 } \\
\text { rft3-7 }\end{array}$ & $\begin{array}{c}2013 \\
\text { семья } \\
\text { II }\end{array}$ & $\begin{array}{l}\text { пр. } \\
\mathbf{H}_{01} \\
\mathbf{H}_{02} \\
\mathbf{H}_{03} \\
\mathbf{H}_{04} \\
\mathbf{H}_{05}\end{array}$ & $\begin{array}{c}17 \\
27 \\
81 \\
63 \\
21 \\
9\end{array}$ & $\begin{array}{c}26 \\
21 \\
63 \\
81 \\
27 \\
3\end{array}$ & $\begin{array}{c}27 \\
16 \\
112 \\
112 \\
16 \\
4\end{array}$ & $\begin{array}{c}70 \\
64 \\
256 \\
256 \\
64 \\
16\end{array}$ & $\begin{array}{c}10,87 \\
6,09 \\
1,10 \\
7,13 \\
30,50\end{array}$ & $\begin{array}{c}17 \\
27 \\
\mathbf{8 1} \\
\mathbf{6 3} \\
\mathbf{2 1} \\
\mathbf{9}\end{array}$ & $\begin{array}{c}53 \\
\mathbf{3 7} \\
\mathbf{1 7 5} \\
\mathbf{1 9 3} \\
\mathbf{4 3} \\
\mathbf{7}\end{array}$ & $\begin{array}{c}70 \\
64 \\
256 \\
256 \\
64 \\
16\end{array}$ & $\begin{array}{c}9,20 \\
1,75 \\
0,00 \\
2,31 \\
29,06\end{array}$ & $\begin{array}{c}43 \\
\mathbf{3} \\
\mathbf{9} \\
\mathbf{9} \\
\mathbf{3} \\
\mathbf{3}\end{array}$ & $\begin{array}{c}27 \\
\mathbf{1} \\
7 \\
7 \\
\mathbf{1} \\
\mathbf{1}\end{array}$ & $\begin{array}{c}70 \\
4 \\
16 \\
16 \\
4 \\
4\end{array}$ & $\begin{array}{l}6,88 \\
0,76 \\
0,76 \\
6,88 \\
6,88\end{array}$ \\
\hline $\begin{array}{l}\text { гк-204× } \\
\text { гк-129 }\end{array}$ & $\begin{array}{l}r f o 6 \\
r f t 5 ?\end{array}$ & 2013 & $\begin{array}{l}\text { пр. } \\
\mathbf{H}_{01} \\
\mathbf{H}_{02}\end{array}$ & $\begin{array}{c}70 \\
\mathbf{3} \\
\mathbf{1 2}\end{array}$ & $\begin{array}{c}22 \\
\mathbf{1} \\
\mathbf{3}\end{array}$ & $\begin{array}{c}3 \\
\text { нет } \\
1\end{array}$ & $\begin{array}{c}95 \\
4 \\
16\end{array}$ & $\begin{array}{l}0,09 \\
2,46\end{array}$ & $\begin{array}{c}70 \\
\mathbf{3} \\
\mathbf{3}\end{array}$ & $\begin{array}{c}25 \\
\mathbf{1} \\
\mathbf{1}\end{array}$ & $\begin{array}{c}95 \\
4 \\
4\end{array}$ & $\begin{array}{l}0,09 \\
0,09\end{array}$ & $\begin{array}{c}92 \\
\text { един. } \\
\mathbf{1 5}\end{array}$ & $\begin{array}{l}3 \\
1\end{array}$ & $\begin{array}{l}95 \\
16\end{array}$ & 1,55 \\
\hline $\begin{array}{l}\text { гК-204× } \\
\text { гК-458 }\end{array}$ & \begin{tabular}{|l|} 
rfo6 \\
RFO8, \\
RFO9
\end{tabular} & 2014 & $\begin{array}{l}\text { пр. } \\
\mathbf{H}_{01} \\
\mathbf{H}_{02}\end{array}$ & $\begin{array}{c}149 \\
\mathbf{5 7} \\
\mathbf{5 4}\end{array}$ & $\begin{array}{c}20 \\
7 \\
10\end{array}$ & нет & $\begin{array}{c}169 \\
64 \\
64\end{array}$ & $\begin{array}{l}0,14 \\
1,84\end{array}$ & $\begin{array}{c}149 \\
57 \\
54\end{array}$ & $\begin{array}{c}20 \\
7 \\
10\end{array}$ & $\begin{array}{c}169 \\
64 \\
64\end{array}$ & $\begin{array}{l}0,14 \\
1,84\end{array}$ & & & & \\
\hline $\begin{array}{l}\text { гк-204× } \\
\text { гк-208 }\end{array}$ & rfo6 & 2016 & $\begin{array}{l}\text { пр. } \\
\mathbf{H}_{01}\end{array}$ & $\begin{array}{c}91 \\
\mathbf{3}\end{array}$ & $\begin{array}{c}38 \\
1\end{array}$ & нет & $\begin{array}{c}129 \\
4\end{array}$ & 1,37 & $\begin{array}{c}91 \\
\mathbf{3}\end{array}$ & $\begin{array}{c}38 \\
1\end{array}$ & $\begin{array}{c}129 \\
4\end{array}$ & 1,37 & & & & \\
\hline
\end{tabular}

$*-\chi_{\text {пр. }}^{2}-\chi^{2}$ практическое; $\chi^{2}{ }_{0,05,2}=5,99 ; \chi^{2}{ }_{0,05,1}=3,84$. 
Таблица 6. Реципрокные различия по восстановлению фертильности пыльцы у F1 от скрещивания гк-208 и гк-188 с другими линиями

Table 6. Reciprocal differences of pollen fertility restoration in F1 from the crosses of gc-208 and gc-188 with other lines

\begin{tabular}{|c|c|c|}
\hline $\begin{array}{l}\text { Направление } \\
\text { скрещивания }\end{array}$ & \begin{tabular}{|l|}
$\begin{array}{l}\text { Год изу- } \\
\text { чения }\end{array}$ \\
\end{tabular} & Стерильность цветков и завязываемость коробочек \\
\hline 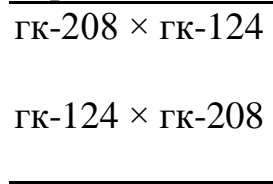 & 2012 & $\begin{array}{l}\text { Пыльники светло-оранжевые, иногда стерильные, хорошая } \\
\text { завязываемость коробочек. } \\
\text { Пыльники голубые, всегда фертильные, хорошая завязывае- } \\
\text { мость коробочек. }\end{array}$ \\
\hline $\begin{array}{l}\text { гК-208 × гК-210 } \\
\text { гК-210 × гК-208 }\end{array}$ & 2013 & $\begin{array}{l}\text { Пыльники серые, тычиночные нити укороченные, пыльца } \\
\text { фертильная, хорошая завязываемость коробочек. } \\
\text { Пыльники голубые, всегда фертильные, цветки гомостиль- } \\
\text { ные, хорошая завязываемость коробочек. }\end{array}$ \\
\hline $\begin{array}{l}\text { гК-208 × гК-2 } \\
\Gamma \kappa-2 \times \text { гК-208 } \\
\end{array}$ & 2008 & $\begin{array}{l}\text { Все фертильны. Хорошая завязываемость коробочек. В } \mathrm{F}_{2} \\
\text { есть растения со стерильными пыльниками. } \\
\text { Все фертильны. Хорошая завязываемость коробочек. }\end{array}$ \\
\hline $\begin{array}{l}\text { гК-208 × гК-288 } \\
\Gamma \kappa-288 \times \text { гК-208 }\end{array}$ & 2004 & Все фертильны. Хорошая завязываемость коробочек. \\
\hline $\begin{array}{l}\text { гК-208 × гК-132 } \\
\text { гК-132 } \times \text { гК-208 } \\
\end{array}$ & 2004 & $\begin{array}{l}\text { Все фертильны. Хорошая завязываемость коробочек. Нет ре- } \\
\text { ципрокных различий в } F_{1} \text { и } F_{2} .\end{array}$ \\
\hline $\begin{array}{l}\text { гК-208 × гК-136 } \\
\text { гК-136 × гК-208 } \\
\end{array}$ & 2004 & $\begin{array}{l}\text { Все фертильны. Хорошая завязываемость коробочек. Нет ре- } \\
\text { ципрокных различий в } F_{1} \text { и } F_{2} \text {. }\end{array}$ \\
\hline $\begin{array}{l}\text { гК-204 × гК- } \\
208 г к-208 \times \text { гК- } \\
204\end{array}$ & $\begin{array}{l}2015, \\
2016\end{array}$ & Все фертильны. Нет реципрокных различий в $\mathrm{F}_{1}$. \\
\hline гК-208 × гк-53 & 2008 & 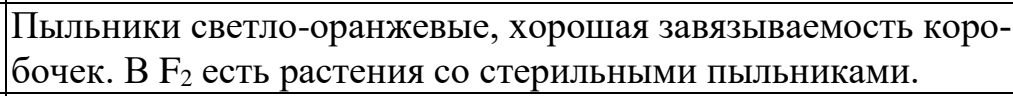 \\
\hline $\begin{array}{l}\text { гК-188 × гК-103 } \\
\text { гК-103 × гК-188 }\end{array}$ & 2011 & ертильны. Нет реципрокных различий в $F_{1}$. \\
\hline
\end{tabular}

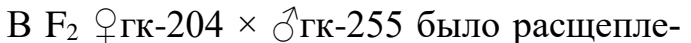
ние 1 ферт. : 4 стер. : 4 трубч. (см. табл. 5). Формально можно выдвинуть те же гипотезы, что и для предыдущего скрещивания, но исходя из урожайности $\mathrm{F}_{1}$ (только 9 семян вместо 100-200), можно предположить, что образование всех гибридов носит случайный характер.

В двух семьях $\mathrm{F}_{2}$ фгкк-204 × наблюдались различные расщепления (см. табл. 5). У первой - 26 ферт. : 18 стер. : 20 трубч.. Это может соответствовать как дигенному ( $\mathrm{H}_{01}$ 27:21:16), так и тригенному $\left(\mathrm{H}_{02}\right.$ 81:61:112) наследованию. Гены rfo6 и $r f o 7$ не мешают проявлению стерильности у открытых цветков, а за трубчатость отвечают гены $r f t 3-6\left(\mathrm{H}_{01}, \mathrm{H}_{02}\right)$ и $r f t 3-7\left(\mathrm{H}_{02}\right)$. Гены «трубчатости» маскируют проявление генов $r f o 6$ и $r f o 7$, то есть расщепление по $\mathrm{H}_{01}$ соответствует 3 открытых (фертильных или стерильных) : 1 трубчатому, а по $\mathrm{H}_{02}-$ 9:7. Для $\mathrm{H}_{02}$ существует излишек класса трубчатых цветков $\left(\chi^{2}=4,06\right)$. У второй семьи было расщепление 17 ферт. : 26 стер. :
27 трубч. Первая гипотеза, выдвинутая для другой семьи, не подтверждается (27:21:16, $\left.\chi^{2}=10,87\right)$, по второй $\left(81: 61: 112, \chi^{2}=6,09\right)-$ есть небольшой излишек класса стерильные открытые цветки, третья гипотеза $\left(61: 81: 112, \chi^{2}=1,10\right)$, верна с математической точки зрения, но кажется нам ошибочной, так как подразумевает смену доминирования у генов $r f o 6$ и $r f o 7$. Вероятней всего, отцовская линия гетерогенна по генам $r f t 3-6$ и $r f t 3-7$, и для каждой из семей справедлива своя гипотеза.

Последняя группа скрещиваний (Фгк-

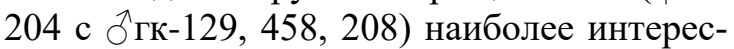
на для селекционеров, так как отцовские линии являются хорошими восстановителями фертильности.

В $\mathrm{F}_{2}$ Фгк-204 × §ٓгк-129 наблюдалось расщепление 70 ферт. : 22 стер.: 3 трубч. (см. табл. 5). Его могут объяснять две гипотезы. $\mathrm{H}_{01}$ (3 ферт.: 1 стер.) предполагает что 3 гибрида с открытыми цветками были описаны ошибочно как трубчатые, и стерильность контролируется помимо цито- 
плазмы геном rfo6 материнской линии. $\mathrm{H}_{02}$ (12:3:1) объясняется наличием гена rft5, работающим только совместно с геном rfo6.

$\mathrm{B} \mathrm{F}_{2}$ ○ гк-204 × $\widehat{~}$ гк-458 было расщепление 149 ферт. : 20 стер. (см. табл. 5). Здесь наблюдается тригенное расщепление и отцовская линия несет три гена восстановителя фертильности - основной ген RFO6 и два дополнительных доминантных (RFO8, RFO9), с кумулятивным ( $\left.\mathrm{H}_{01} 57: 7\right)$, либо независимым действием и подавляющие друг друга $\left(\mathrm{H}_{02}\right.$ 54:10). Восстановитель фертильности (к-7776), из которого получена линия гк-458, специально отбирался по этому признаку из сорта 'Bolley Golden', родоначальника гк-129.

Расщепление $\mathrm{F}_{2}$ фгкк-204 × $ぇ$ гк-208 соответствует моногенному по гену rfo6 (см. табл. 5).
Другой источник ЦМС - линия гк-208, полученная из сорта 'Pale Blue Crimped' (к- 7947, США). Сама линия и все отцовские формы в скрещиваниях с ней абсолютно фертильны, то есть здесь стерильность име-ет гибридогенный характер. Она имеет еще более варьирующую экспрессивность, чем у гк-204, выраженность которой менялась при использовании различных отцовских форм и от года изучения. У растений $\mathrm{F}_{1}$ иногда были реципрокные различия, касающиеся окраски пыльников (серые или светло-оранжевые, вместо голубых), а так-же единичные стерильные цветки, что не сказывалось на завязываемости семян (табл. 6).

Таблица 7. Генетический контроль мужской стерильности

у F2 от скрещивания ९гк-208 с о̛тк-124, 210 и ९гк-188 с о̛'гк-103

Table 7. Genetic control of male sterility in F2 from the crosses of $9 g c-208$ witho' gc-124, 210 and $9 g c-188$ with ơgc-103

\begin{tabular}{|c|c|c|c|c|c|c|c|c|c|c|c|c|c|c|c|c|}
\hline \multirow{2}{*}{\multicolumn{4}{|c|}{ Скрещивание }} & \multirow{2}{*}{\multicolumn{3}{|c|}{$\begin{array}{c}\text { Цветок } \\
\text { /пыльники } \\
\end{array}$}} & \multirow{3}{*}{$\sum$} & \multirow{3}{*}{$\chi_{\text {пр. }}^{2}$} & \multirow{2}{*}{\multicolumn{2}{|c|}{ Пыльники }} & \multirow{3}{*}{$\sum$} & \multirow{3}{*}{$\chi^{2}$ пр. } & \multirow{2}{*}{\multicolumn{2}{|c|}{ Цветок }} & \multirow{3}{*}{$\sum$} & \multirow{2}{*}{$\begin{array}{l}\chi^{2} \\
\text { пр. }\end{array}$} \\
\hline & & & & & & & & & & & & & & & & \\
\hline линии & гены & Год & $\mathrm{H}_{0}$ & ферт. & стер. & стер. & & & ферт & стер. & & & откр. & труб. & & \\
\hline \multirow{5}{*}{$\begin{array}{l}\text { гК- } \\
208 \times \\
\text { гК-124 }\end{array}$} & 06 & & & \multirow{3}{*}{\multicolumn{2}{|c|}{73}} & 34 & & & & & & & 73 & 34 & & \\
\hline & & 15 & & & & & & & & & & & & & & \\
\hline & \multirow{3}{*}{$\begin{array}{l}\text { rft3-7 } \\
\text { rfo6-2 }\end{array}$} & & $\mathrm{H}_{01}$ & & & 1 & 4 & 2,62 & & & & & 3 & 1 & 4 & 2,62 \\
\hline & & 2014 & пр. & 149 & 47 & 57 & 253 & & 149 & 104 & 253 & & 196 & 57 & 253 & \\
\hline & & & $\mathrm{H}_{02}$ & 9 & 3 & 4 & 16 & 0,94 & 9 & 7 & 16 & 0,72 & 3 & 1 & 4 & 0,82 \\
\hline \multirow{6}{*}{$\begin{array}{l}\text { гК- } \\
208 \times \\
\text { гК-210 }\end{array}$} & \multirow{6}{*}{$\begin{array}{l}\text { RFO6 } \\
\text { rfo6-3 } \\
\text { rft6 } \\
\text { rft7 }\end{array}$} & \multirow[t]{3}{*}{2015} & пр. & 191 & 30 & 4 & 225 & & 191 & 34 & 225 & & 221 & 4 & 225 & \\
\hline & & & $\mathrm{H}_{01,02}$ & 54 & 9 & 1 & 64 & 0,16 & 54 & 10 & 64 & 0,05 & 63 & 1 & 64 & 0,07 \\
\hline & & & $\mathrm{H}_{03}$ & 57 & 6 & 1 & 64 & 4,27 & 57 & 7 & 64 & 4,02 & 63 & 1 & 64 & 0,07 \\
\hline & & \multirow[t]{3}{*}{2016} & пр. & 54 & 7 & 2 & 63 & & 54 & 9 & 63 & & 61 & 2 & 63 & \\
\hline & & & $\mathrm{H}_{01,02}$ & 54 & 9 & 1 & 64 & 1,45 & 54 & 10 & 64 & 0,09 & 63 & 1 & 64 & 1,06 \\
\hline & & & $\mathbf{H}_{03}$ & 57 & 6 & 1 & 64 & 1,33 & 57 & 7 & 64 & 0,73 & 63 & 1 & 64 & 1,06 \\
\hline \multirow{2}{*}{$\begin{array}{l}\text { гК- } \\
188 \times \\
\text { ГК-103 }\end{array}$} & \multirow[b]{2}{*}{$\begin{array}{l}\text { rfo7, } \\
\text { rft5-2 }\end{array}$} & \multirow[t]{2}{*}{2016} & & 134 & 33 & 6 & 173 & & 134 & 39 & 173 & & 167 & 6 & 173 & \\
\hline & & & $\mathrm{H}_{01}$ & 12 & 3 & 1 & 16 & 2,29 & 3 & 1 & 4 & 0,56 & 15 & 1 & 16 & 2,28 \\
\hline
\end{tabular}

В «тесте на аллелизм» с первым источником ЦМС ( гк-204 × $\subsetneq$ гк-208), в прямом направлении расщепление по стерильности соответствовало моногенному, тогда как в обратном - все гибриды были фертильны (см. табл. 5).

У $\mathrm{F}_{2}$ фгкк-208 × ठิгк-124 наблюдалось теоретическое расщепление 9 ферт. : 3 стер. : 4 трубч., $\chi^{2}=0,94$. Ген $r f o 6-2$, полученный от гк-124, не мешает проявлению стерильности и не влияет на открытость цветка, тогда как ген $r f t 3-7$ в дополнение к мужской стерильности приводит к деформации венчика (табл. 7).

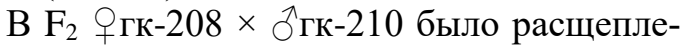
ние 191 ферт. : 30 стер. : 4 трубч. (см.табл. 7). Объяснением этого могут служить три гипотезы. По первой из них $(54: 9: 1)$ ген rfo6-3 полученный от гк-210 не мешает проявлению стерильности, два других гена $r f t 6$ и $r f t 7$ взаимодействуя между собой и геном rfo6-3 по принципу некумулятивной полимерии (63 откр. : 1 трубч.) дают трубчатый стерильный цветок. По второй гипо- 
тезе (54:9:1), три рецессивных гена с кумулятивным действием не мешают проявлению стерильности, при нахождении двух из них в гомозиготе - цветки стерильные, а всех трех - трубчатые. Третья гипотеза (57:6:1) подразумевает, что для стерильности необходимо, чтобы ген $r f o 6-3$ и один из двух других (rft6 и rft7) были в гомозиготе. При последней гипотезе есть небольшой избыток класса гибридов со стерильным открытым цветком.

В скрещиваниях Фгк-208 с ภ̄гк-2 и 53 в $\mathrm{F}_{2}$ также встречались стерильные растения. Все растения $\mathrm{F}_{1}$ и $\mathrm{F}_{2}$ ๆ гк-208 с ठิ гк-188, 132, 136 были фертильны.

Третий источник ЦМС - линия гк-188, полученная из местного индийского образца (к-3002). Она имеет тот же фенотип и генотип (ген $p b c 1)$ по окраске цветка, что и гК-208.

В $\mathrm{F}_{2}$ Фгк-188 × సٓгк-103 наблюдалось теоретическое расщепление 12 ферт. : 3 стер. : 1 трубч. (см. табл. 7). Ген rfo7 (тот же, что и у гк-176, дочерней гк-103) не мешает стерильности открытых цветков. Трубчатость контролирует ген rft5-2, действие которого проявляется только у гомозигот по гену rfo7.

\section{Заключение}

Из трех типов ЦМС $\left(\mathrm{Cyt}^{\mathrm{s} 1}, \mathrm{Cyt}^{\mathrm{s} 2} \mathrm{Cyt}^{\mathrm{s} 3}\right)$ предпочтительней первая. Выявленные аллели генов восстановления фертильности по характеру проявления можно отнести к трем типам. Первые имеют большую селекционную ценность для введения в источники и (или) закрепители ЦМС, так как, не мешая проявлению стерильности, не влияют на форму венчика (rfo6, rfo6-2, rfo63 , rfo 7). Вторые - контролируют трубчатые стерильные цветки и могут быть как рецессивными (rft3-2, rft3-3, rft3-6, rft3-7, rft5-2, $r f t 6, r f t 7)$, так и доминантными (RFT4-3). Эти гены нежелательны для селекции, так как снижают вероятность перекрестного опыления. Третьи (RFO8, RFO9), восстанавливают фертильность, у гибридов со стерильной цитоплазмой и геном rfo6. Эти гены были получены селекционерами ВНИИМК и должны быть востребованы в гетерозисной селекции. Возможно, гены, имеющие одинаковые префиксы, аллельны, например, rfo6-2 и rfo6-3, но тесты на аллелизм для них не проводились.

\section{References/Литература}

Anashhenko A. V. Male sterility of sunflower ( $\mathrm{He}$ lianthus annuus L.) (Muzhskaya steril'nost' u podsolnechnika (Helianthus annuus L.) Avtoref. ...kand. s.-kh. nauk, Leningrad, 1968, 24 p. [in Russian] (Анащченко A. В. Мужская стерильность у подсолнечника (Helianthus annuus L.) // Автореф. дисс. ... канд. биол. наук, Л: 1968, 24 с.).

Anisimova I. N., Gavrilova V.A. Structural and functional diversity of the genes that suppress phenotype of cytoplasmic male sterility in plants // Proceedings of applied botany, genetics and breeding, 2012, vol. 170, pp. 3-16 [in Russian] (Анисимова И. Н., Гаврилова В. А. Структурно-функциональное разнообразие генов, супрессирующих фенотип цитоплазматической мужской стерильности у растений // Тр. по прикл. бот., ген. и сел. 2012. Т. 170. C. 3-16).

Baranova E. G., Ivanitskii K. I., Suchkov V. I. Formation of gene pool of sources of cytoplasmatic male sterility of tobacco // Apriory. Series: Natural and Technical Sciences, 2015, no. 2, pp. 118 [in Russian] (Баранова Е. Г., Иваницкий К. И., Сучков В. И. Формирование генофонда источников цитоплазматической мужской стерильности табака // Apriori серия: есте- ственные и технические науки. 2015. № 2. С. $1-18)$.

Bateson W. M A., Gairdner A. E. Male-sterility in flax, subject to two types of segregation // Genetics, 1921, vol. 11, pp. 269-275.

Chen W., Yu X.-H., Zhang X. et all. Zhang Male Sterile 2 encodes a plastid-localized fatty acyl carrier protein reductase required for pollen exine development in Arabidopsis // Plant physiology, 2011, vol. 157, pp. 842-853.

Comstock $V$. E. Possibility of hybrid flax production $/ / 35^{\text {th }}$ Annual Flax Institute of the USA, Minneapolis, 1965, pp. 24-25.

Comstock V. E., Ford J. H. Association of seed color with viability of stored flax seed // $38^{\text {th }}$ Annual Flax Institute of the USA, 1968, Minneapolis, pp. 20-22.

Comstock V. E. Natural crossing onto male - sterile flax and association of male sterility with seed color $/ / 40^{\text {th }}$ Annual flax Institute of the USA, Minneapolis: 1970, pp. 8-9.

Danilenko N. G., Davydenko O. G. Worlds organelles genomes (Miry genomov organell). Minsk, 2003, 498 p. [in Russian] (Даниленко Н. Г., Давыденко О. Г. Миры геномов органелл. Минск, 2003. 498 с.).

Dubey D. K., Singh S. P. Mechanism of pollen abortion in three male sterile lines of flax $(\mathrm{Li}$ - 
num usitatissimum L.) // Crop science, 1965, vol. 5, pp. 121-124.

Dubey D. K., Singh S. P. Use of cytoplasmic male sterility for production of hybrid seeds in flax (Linum usitatissimum L.) // Crop science, 1966, vol. 6 , pp. 125-127.

Gairdner A. Male sterility in flax II A case of reciprocal crosses differing in F2 // Journal of genetics, 1929, vol. 21, pp.117-124.

Hanson M. R., Bentolila S. Interactions of mitochondrial and nuclear genes that affect male gametophyte development // The Plant Cell, 2004, vol. 16, pp. 154-169. DOI: $10.1105 / \mathrm{tpc} .015966$.

Hui Z., Bateer S., Xiao-yun J., Zi-qin L., Qiang L. Study on genes related to male sterility in dominant genic male sterile flax // Proceedings of the $63^{\text {rd }}$ flax institute of the United States. Fargo, North Dakota: Flax Institute of the United States, 2010, pp. 112-122 (abstract).

Kumar S., Jordan M. C., Datla R., Cloutier S. The LuWD40-1 gene encoding WD repeat protein regulates growth and pollen viability in flax (Linum usitatissimum L.). PLoS ONE. 2013. vol. 8, no. 7, pp. 1-10. DOI: 10.1371/journal.pone.0069124

Kumar S. Male sterility in vegetables // In: Olericulture - fundamental of vegetable production, 2013, vol. 1, pp. 431-439.

Kumar S., Singh S. P. Inheritance of male-sterility in some introduced varieties of linseed (Linum usitatissimum L.) // Indian Journal agricultural science, 1970, vol. 40, no. 2, pp. 184-191.

Kumar S., Singh S. P. Inheritance of partial male fertility in linseed (Linum usitatissimum L.) // Indian Journal agricultural science, 1972, vol. 42, no. 1, pp. 34-38.

Marchenkov A. N. Using forms from VIR world collection for studyng CMS in fibre-flax // Bul- letin of applied botany, genetics and plant breeding, 1979, vol. 64, iss. 2, pp. 74-78 [in Russian] (Марченков А. Н. Использование материалов коллекции ВИР при изучении ЦМС у льна долгунца // Тр. по прикл. бот., ген. и сел. 1979. Т. 64. Вып. 2. С. 74-78)

Nasledov A. D. Mathematical methods of psychological analysis. Data analysis and interpretation. St Petersburg: Rech, 392 p. [in Russian] (Matematicheskie metody psixologicheskogo issledovaniya Analiz i interpretaciya dannyx. (Наследов А. Д. Математические методы психологического исследования. Анализ и интерпретация данных. СПб.: Речь, 2012. 392 c.).

Rhoades M. M. Cytoplasmic inheritance of male sterility in Zea mais // Science, 1931, no. 1891, pp. 340-341.

Rykova $R$. P. The sources of cytoplasmic male sterility in flax // Bulletin of applied botany, genetics and plant breeding, 1979, vol. 64, iss. 2, pp. 52-58 [in Russian] (Рыкова Р. П. Источники цитоплазматической мужской стерильности льна // Тр. по прикл. бот., ген. и сел. 1979. Т. 64. Вып. 2. С. 52-58).

Sorochinskaya M. A., Galkin F. M. The raw material and breeding of linseed in VNIIMK (Isxodnyj material i rezul'taty selekcii po l'nu maslichnomu vo VNIIMK) // Bulletin of the N.I. Vavilov institute of plant industry 1977, iss. 69, pp. 3034 [in Russian] (Сорочинская М. А., Галкин $\Phi$. М. Исходный материал и результаты селекции по льну масличному во ВНИИМК // Бюлл. ВНИИР им. Н.И. Вавилова. 1977. Вып. 69. С. 30-34).

StatSoft, Inc. Electronic Statistics Textbook. Tulsa, OK: StatSoft. 2013 URL. http://www.statsoft. com/textbook 


\section{ИАЕНТИФИКАЦИЯ ГЕНЕТИЧЕСКОГО РАЗНООБРАЗИЯ КУАЬТУРНЫХ РАСТЕНИЙ И ИХ АИКИХ РОАИЧЕЙ ААЯ РЕШЕНИЯ ФУНААМЕНТААЬНЫХ И ПРИК АААНЫХ ПРОБАЕМ}

DOI: $10.30901 / 2227-8834-2017-1-82-91$

\section{У. И. Канцаева, \\ В. М. Горина}

Никитский ботанический сад Национальный научный центр, 298648, Россия, Республика Крым, г. Ялта, п.г.т. Никита,

Никитский спуск, д. 52, e-mail: angi1959@mail.ru

Ключевые слова:

алыча, гибридная алыча, Prunus cerasifera, Prunus $\times$ rossica, Rosaceae, copm, морфолого-биологические признаки, отличимость, однородность, стабильность

Поступление: 05.11 .2016

Принято: 06.03.2017

\section{МОРФОЛОГО-БИОЛОГИЧЕСКИЕ ПРИЗНАКИ КРУПНОПЛОДНОЙ АЛЫЧИ (PRUNUS × ROSSICA EREMIN) И ИХ ЗНАЧЕНИЕ ДЛЯ ПРОВЕДЕНИЯ ЭКСПЕРТИЗЫ СОРТОВ НА ОТЛИЧИМОСТЬ, ОДНОРОДНОСТЬ И СТАБИЛЬНОСТЬ (ООС)}

Актуальность. Алыча - вид сливы, который характеризуется высокой продуктивностью. Для придания правовой охраны, сортам алычи, внесенным в Реестр сортов, допущенных к использованию, необходимо при экспертизе на отличимость, однородность и стабильность в качестве критерия признания сорта привлекать морфолого-биологические признаки. Материалы и методы. Исследовали морфолого-биологические признаки пяти новых перспективных сортов гибридной алычи (Prunus $\times$ rossica Eremin - Слива русская). Сорт 'Обильная' был взят в качестве контроля. Сорта, полученные в Никитском ботаническом саду, были включены в Реестр сортов, утвержденных для использования на Украине и юге России. Исследования проводили в соответствии с методами УПОВ. Результаты. Анализ сроков цветения растений и созревания плодов, морфологических признаков дерева, листьев, плодов показывает, что все изучаемые сорта соответствуют критериям отличимости, однородности и стабильности. Проведенные исследования подтверждают возможность уверенно отличать сорта-кандидаты от известных, широко выращиваемых сортов путем сравнения зарегистрированных описаний растений. Выводы. Выявлено значение морфолого-биологических признаков при экспертизе сортов Prunus $\times$ rossica на отличимость, однородность и стабильность как основных критериев признания сорта. Изученные сорта ('Андромеда', ‘Десертная Ранняя', 'Обильная', 'Оленька', 'Румяная Зорька', 'Фемида') удовлетворяют критериям отличительности, однородности и стабильности. 


\section{IDENTIFICATION OF THE DIVERSITY OF CULTIVATED PLANTS AND THEIR WILD RELATIVES FOR SOLVING FUNDAMENTAL AND APPLIED PROBLEMS}

\section{U. I. Kantsayeva, V. M. Gorina}

Nikitsky Botanical Garden National Scientific Center, 52, Nikitsky Spusk, Nikita Township, Yalta, 298648, Republic of Crimea, Russian Federation,

e-mail: angi1959@mail.ru

Key words:

cherry plum, hybrid cherry

plum, Prunus cerasifera,

Prunus $\times$ rossica, Rosaceae, variety, morphological and biological traits, distinctness, homogeneity, stability

Received:

05.11 .2016

Accepted:

06.03.2017
ORIGINAL ARTICLE

\section{MORPHOLOGICAL AND BIOLOGICAL TRAITS OF LARGE- FRUITED CHERRY PLUM (PRUNUS $\times$ ROSSICA EREMIN) AND THEIR IMPORTANCE FOR EXPERT EXAMINATION OF VARIETIES FOR THEIR DISTINCTNESS, HOMOGENEITY AND STABILITY (DHS)}

Background. Cherry plum is a species of the genus Prunus characterized by high productivity. To provide legal protection for cherry plum varieties listed in in the Register of Varieties Approved for Utilization, morphological and biological traits should be applied as the criteria for recognition of a variety during the expert examination for distinctness, homogeneity and stability. Materials and methods. The research was targeted at morphological and biological characters of 5 promising varieties of hybrid cherry plum (Prunus $\times$ rossica Eremin). Variety 'Obil'naya' was control. The varieties developed by Nikitsky Botanical Garden were included in the Register of Varieties Approved for Utilization in Ukraine and Southern Russia. The research has been performed according to the UPOV methods. Results. The analysis of the tree, leaf and fruit morphological characters and the time of flowering and fruit ripening has shown that all studied varieties meet the criteria for distinctness, homogeneity and stability. The research confirms the possibility to distinguish the candidate varieties from the already known and widely cultivated ones by comparing the recorded plant descriptions. Conclusions. The importance of morphological and biological traits in the expert examination of the Prunus $\times$ rossica varieties for their distinctness, homogeneity and stability has been shown for the studied varieties ('Andromeda', 'Desertnaya Rannyaya', 'Obil'naya', 'Olen'ka', 'Rumyanaya Zor'ka' and 'Femida'). All of them meet the criteria for distinctness, homogeneity and stability. 


\section{Введение}

Алыча (Prunus cerasifera Ehrh.) - один из видов диплоидных слив (Rosaceae Juss.), сорта которой выращивают в самых разных странах - в России, Беларуси, Украине, Молдове, Греции, Турции, Болгарии, Иране, Италии, Франции и других. Популярность алычи, как плодовой культуры, заключается в неприхотливости растений. Она растет на самых разных почвах - от гравийных и песчаных до карбонатных и серых лесных. Деревья могут иметь как один, так и несколько стволов. Их высота значительно варьирует от низкорослых до очень высоких, достигающих 15 и более метров. Цветение алычи начинается рано, цветки нежного кремового, розоватого или белого цветов распускаются раньше или одновременно с листочками. Листья чаще всего бывают овальной или яйцевидной формы. Плоды алычи разнообразны по размеру, форме, вкусу, окраске кожицы и мякоти. Кроме привычной алычи с желтой окраской кожицы есть сорта с кожицей красного, розового, бордового, оранжевого и фиолетового цветов. В плодах имеются биологически активные вещества, полезные для организма человека. Они содержат до $25 \%$ сухих веществ, $16 \%$ сахаров, $1,5-4,0 \%$ органических кислот, кальций, фосфор, калий, витамины $\mathrm{B}_{1}, \mathrm{~B}_{2}, \mathrm{C}, \mathrm{E}, \mathrm{PP}$, что позволяет использовать их для диетического питания. Плоды алычи характеризуются универсальностью использования. Они хороши как в свежем, так и в переработанном виде (Smykov, Gorina, 1999). Сегодня алычу, некогда считавшуюся пригодной лишь для выращивания на юге, успешно культивируют в более северных районах. Такое успешное расширение ее ареала связано с созданием гибридных сортов алычи, полученных с участием сливы китайской ( $P$. salicina Lindl.), а позже - и других видов слив. Сорта крупноплодной алычи, несмотря на свое гибридное происхождение, характеризуются стабильными генетическими системами, имеют широкий ареал возделывания, что позволило Г. В. Еремину выделить их в самостоятельный культигенный диплоидный вид сливы $P$. $\times$ rossica Eremin Слива русская (Eremin, 2003). Растения от- личаются скороплодностью, крупноплодностью и высокой урожайностью. Саженцы начинают плодоносить уже на следующий год после посадки в сад, обеспечивая довольно быстрый возврат капитальных вложений на его создание.

Как известно, сорта характеризуются совокупностью многих признаков и свойств отдельных органов или растения в целом. К ним относятся морфологические признаки: высота и форма кроны; длина и ширина листьев; интенсивность окраски листьев, величина и форма плода; наличие или отсутствие опушения на кожице; окраска семян и плодов, и т. д. Сроки цветения растений и созревания плодов определяют биологические особенности сортов. Каждый генотип имеет свои, только ему свойственные, морфолого-биологические признаки, по которым идентифицируют и описывают конкретный сорт или гибрид, отличают новые сорта от известных, широко выращиваемых генотипов, определяют однородность и стабильность сорта или гибрида. Это особенно важно для характеристики сортов $P$. $\times$ rossica.

Целью проведенного исследования явилось определение значения морфологобиологических признаков новых сортов при их экспертизе на отличимость, однородность и стабильность, как основных критериев признания сорта как такового, внесении сортов в Реестр, допущенных к использованию и придании им правовой охраны, как объектам интеллектуальной собственности.

\section{Материалы и методы}

Объектами исследований были шесть сортов гибридной алычи $(P . \times$ rossica $)$ ceлекции Никитского ботанического сада (НБС - ННЦ): 'Андромеда', 'Десертная Ранняя', 'Обильная', 'Оленька', 'Румяная Зорька' 'Фемида'. Годы исследований включают период плодоношения растений изучаемых сортов в молодом возрасте, дающих полноценный урожай (5-10-летние) и во взрослом состоянии (15-20-летние). Фенологические наблюдения проводили по общепринятым методикам (Programme and methodology..., 1973; Programme and meth- 
odology..., 1999). Все количественные характеристики определяли на генотипах с минимумом 15-ти типичных органов или частей растений. Все наблюдения, относящиеся к почкам, листьям и побегам выполняли в центральной трети зрелых побегов текущего сезона. Цветки исследовали во время полного цветения, плоды - полного созревания. Исследования на отличимость, однородность и стабильность осуществляли согласно методике проведения экспертизы диплоидных видов сливы (Official website..., 1998). Испытания проводили в условиях, обеспечивающих нормальный рост растений. Опыты по испытанию однородности и стабильности показали, что, в случае вегетативно размножаемых сортов алычи, достаточно определить, однороден ли растительный материал в отношении наблюдаемых характеристик и нет ли мутаций или химер. Для оценки на отличимость сорта были разбиты на группы, использовали признаки, которые, не варьируют или варьируют незначительно в пределах сорта, или их варьирование в пределах коллекции распределено равномерно. В оценку включали следующие признаки плода: размер (признак 30), основная окраска кожицы (признак 36), общая форма в профиль (признак 31), форма верхушки (признак 34), окраска мякоти (признак 38), плотность мякоти (признак 37); косточки: размер (признак 43), общая форма в профиль (признак $44)$; время начала цветения (признак 57); время начала созревания плодов (признак $58)$ и др. Для оценки однородности использовали популяционный стандарт $1 \%$ при доверительной вероятности 95\%. В случае выборки из 4 растений число нетипичных 0. Экспертиза предполагает определение однородности, отличительности и стабильности сортов. Сорт считается отличимым, если он явно отличается от любого другого сорта, который является известным и широко распространенным на момент регистрации заявки (Official website..., 2008a). Сорт считается однородным, если с учетом особенностей его размножения растения этого сорта достаточно однородны по своим основным признакам (Official website..., 2008b). Сорт считается стабильным, если его основные признаки остаются неизмен- ными после неоднократного размножения или, в случае особого цикла размножения, в конце каждого такого цикла (Official website..., 2008c). Работу выполняли в условиях южного берега Крыма (г. Ялта) и в степном Крыму (с. Новый Сад), характеристика которых приведена по «Климатическому атласу Крыма» и работе В. И. Важова (Vazhov, 1977; Climatic Atlas..., 2000). Участок на южном берегу Крыма расположен на высоте 195-200 м над уровнем моря. Рельеф ступенчато-террасовый, овражнобалочный. Почвы бурые, горнолесные и коричневые на продуктах выветривания глинистых сланцев и известняков. Климат средиземноморский, засушливый, с очень мягкой зимой. Средняя температура воздуха $12-14^{\circ} \mathrm{C}$. Наиболее теплые месяцы июль - август $\left(23-25^{\circ} \mathrm{C}\right.$, иногда $\left.35-40^{\circ} \mathrm{C}\right)$. Самый холодный месяц - январь $\left(2,5^{\circ}-\right.$ $\left.4,5^{\circ} \mathrm{C}\right)$. Средняя из абсолютно минимальных температур $-6 \ldots-9^{\circ} \mathrm{C}$, абсолютный минимум $-15 \ldots-17^{\circ} \mathrm{C}$. Сумма температур выше $+10^{\circ} \mathrm{C}$ составляет $3940^{\circ}$, выше $+15^{\circ}-$ $3245^{\circ} \mathrm{C}$. Годовое количество осадков -550 мм, из них в вегетационный период выпадает 260 мм. Наибольшее их количество наблюдается в декабре - 75 мм в месяц, а минимальное - 29 мм - в апреле и мае. Зимой периоды с устойчивыми среднесуточными температурами воздуха ниже $0^{\circ} \mathrm{C}$ наблюдаются крайне редко. Осадки в виде снега выпадают ежегодно, но снежный покров в прибрежной полосе сохраняется до 12 суток, а на верхней границе - до 24. Высота снежного покрова от 9-13 до 40-45 см. Безморозный период достигает 259 суток, а вегетационный - 212. Повторяемость зимних вегетационных оттепелей составляет 65-70\% от общего числа лет наблюдений. Повреждение морозами плодовых растений возможно не более чем в $2-3 \%$ зим. В Степном отделении Никитского ботанического сада, расположенном на границе центрально-степной и предгорной зон, годовая сумма осадков достигает в среднем 350-400 мм. В летний период сумма осадков составляет 147 мм (41\% от годовой нормы). Лето жаркое, со среднесуточной температурой воздуха в июле $23-24^{\circ} \mathrm{C}$. Максимальная температура в июле и августе находится в интервале $35-39^{\circ} \mathrm{C}$. Средние показатели 
температуры воздуха самых холодных месяцев (январь - февраль) составляют $3,5 \ldots-3,8^{\circ} \mathrm{C}$. Средние из абсолютных годовых минимумов достигают $-18,0 \ldots-21,0^{\circ} \mathrm{C}$, абсолютный минимум $-30 \ldots-35^{\circ} \mathrm{C}$. Кроме того, климат степных районов характеризуется большой сухостью воздуха. С июня по сентябрь средняя относительная влажность воздуха в 13 часов дня достигает 40-45\%. В период вегетации часто бывают длительные перерывы в выпадении осадков и снижении влажности воздуха. В сочетании с действием высоких температур наблюдаются периодические засухи и суховеи. Запасы влаги за летний период значительно уменьшаются. Период со среднесуточными температурами $10^{\circ} \mathrm{C}$ и выше продолжается 6,0-6,5 месяцев.
Почва южные черноземы, сформировавшиеся на рыхлых осадочных породах, имеющих благоприятные свойства для роста и развития растений, но содержащие невысокое количество гумуса $(2,6-2,9 \%)$.

\section{Результаты и обсуждение}

Многолетние исследования морфологобиологических признаков алычи позволили отобрать, среди созданных в Никитском ботаническом саду генотипов, новые перспективные сорта гибридной алычи $(P . \times$ rossica $)$ и ввести их в Реестр сортов, допущенных к использованию в Украине и на юге России.

\section{Таблица 1. Результаты изучения морфологических признаков дерева и листьев сортов гибридной алычи селекции НБС-ННЦ для экспертизы на отличительность, однородность и стабильность}

Table 1. Results of studying the tree and leaf morphological characters in the hybrid cherry plum varieties bred by NBG for the expert examination of their distinctness, homogeneity and stability

\begin{tabular}{|c|c|c|c|c|c|c|c|c|}
\hline \multirow[b]{2}{*}{ Сорт } & \multicolumn{2}{|c|}{ Дерево } & \multicolumn{5}{|c|}{ Листовая пластинка } & \multirow{2}{*}{$\begin{array}{c}\text { Черешок } \\
\text { 茛 }\end{array}$} \\
\hline & 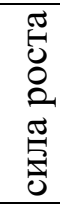 & 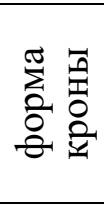 & 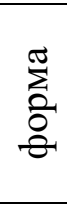 & 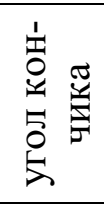 & 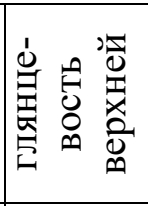 & 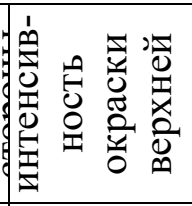 & 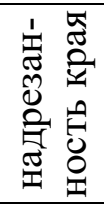 & \\
\hline $\begin{array}{l}\text { Андро- } \\
\text { меда }\end{array}$ & 7 & 5 & 2 & 1 & 3 & 5 & 2 & 3 \\
\hline $\begin{array}{l}\text { Десерт- } \\
\text { ная Ран- } \\
\text { няя }\end{array}$ & 5 & 5 & 3 & 1 & 3 & 5 & 1 & 5 \\
\hline Обильная & 5 & 3 & 3 & 1 & 3 & 7 & 1 & 3 \\
\hline Оленька & 5 & 5 & 2 & 1 & 3 & 7 & 2 & 3 \\
\hline $\begin{array}{l}\text { Румяная } \\
\text { Зорька }\end{array}$ & 5 & 5 & 2 & 1 & 5 & 7 & 1 & 5 \\
\hline Фемида & 5 & 5 & 2 & 1 & 3 & 3 & 1 & 3 \\
\hline
\end{tabular}

Анализ морфологических признаков дерева и листьев (табл. 1) показывает, что по всем сортам сила роста растения определяется кодами степени проявления признаков 5 и 7, что соответствует среднерослому и сильнорослому их состоянию. Высокая плотность кроны определяется кодом 7 (густая). Сорт 'Десертная Ранняя' отличается редкой кроной (код степени проявления 3 ). Растений с густой кроной среди изучаемых сортов не выявлено. Форма листовой пластинки по всем сортам соответствует степени проявления признаков - индексы 2 и 3 (широкоовальная и эллиптическая). Угол кончика у листьев всех шести сортов - острый. Интенсивность окраски верхней сто- 
роны листовой пластинки варьирует: от ность края листовой пластинки по сортам светлой ('Фемида') к средней ('Андроме- охватывает проявление признаков: 1 - года', 'Десертная Ранняя') и темной ('Обиль- родчатая, 2 - пильчатая, длина черешка: ная', 'Оленька', 'Румяная Зорька'). Глянце- короткая и средняя (коды проявления 3 и вость верхней стороны листа у большин- 5). ства изучаемых сортов слабая. Надрезан-

Таблица 2. Результаты изучения морфолого-биологических признаков сортов гибридной алычи селекции НБС-ННЦ для экспертизы на отличительность, однородность и стабильность

Table 2. Results of studying morphological characters of the hybrid cherry plum bred by NBG for the expert examination of distinctness, homogeneity and stability

\begin{tabular}{|c|c|c|c|c|c|c|c|c|c|c|}
\hline \multirow[t]{2}{*}{ Сорт } & \multicolumn{6}{|c|}{ Плод: } & \multicolumn{2}{|c|}{ Косточка: } & \multirow[b]{2}{*}{$\begin{array}{l}\text { Вре- } \\
\text { мя } \\
\text { нача- } \\
\text { ла } \\
\text { цвете } \\
\text { ния }\end{array}$} & \multirow[b]{2}{*}{$\begin{array}{l}\text { Время } \\
\text { начала } \\
\text { созре- } \\
\text { ва } \\
\text { ния } \\
\text { пло- } \\
\text { дов }\end{array}$} \\
\hline & $\begin{array}{l}\text { ра3- } \\
\text { мер }\end{array}$ & $\begin{array}{l}\text { фор- } \\
\text { ма в } \\
\text { про } \\
\text { филь }\end{array}$ & $\begin{array}{l}\text { форма } \\
\text { верхуш- } \\
\text { ки }\end{array}$ & $\begin{array}{l}\text { основ } \\
\text { ная } \\
\text { окрас- } \\
\text { ка ко- } \\
\text { жицы }\end{array}$ & $\begin{array}{l}\text { окрас- } \\
\text { ка } \\
\text { мяко- } \\
\text { ти }\end{array}$ & $\begin{array}{l}\text { плот } \\
\text { ность } \\
\text { мяко- } \\
\text { ти }\end{array}$ & $\begin{array}{l}\text { ра3- } \\
\text { мер }\end{array}$ & $\begin{array}{l}\text { фор- } \\
\text { ма в } \\
\text { про } \\
\text { филь }\end{array}$ & & \\
\hline $\begin{array}{l}\text { Андро } \\
\text { меда }\end{array}$ & 7 & 3 & 1 & 7 & 2 & 5 & 3 & 3 & 5 & 5 \\
\hline $\begin{array}{l}\text { Десерт } \\
\text { ная } \\
\text { Ранняя }\end{array}$ & 7 & 2 & 2 & 8 & 2 & 5 & 5 & 2 & 5 & 5 \\
\hline $\begin{array}{l}\text { Обиль } \\
\text { ная }\end{array}$ & 7 & 2 & 3 & 8 & 2 & 7 & 3 & 2 & 5 & 5 \\
\hline $\begin{array}{l}\text { Олень- } \\
\text { ка }\end{array}$ & 7 & 3 & 1 & 6 & 2 & 7 & 3 & 2 & 5 & 7 \\
\hline $\begin{array}{l}\text { Румя- } \\
\text { ная } \\
\text { Зорька }\end{array}$ & 7 & 3 & 2 & 5 & 2 & 7 & 3 & 3 & 7 & 7 \\
\hline $\begin{array}{l}\text { Феми- } \\
\text { да }\end{array}$ & 7 & 3 & 2 & 9 & 2 & 5 & 5 & 2 & 7 & 5 \\
\hline
\end{tabular}

Размер плодов исследуемых сортов алычи (табл. 2), соответствует коду 7 - большой.

Форма плода в профиль у сортов коти и делает сорта более ценными. 'Десертная Ранняя' и 'Обильная' - Форма косточки в профиль (отношение округлая, у сортов 'Андромеда', длины к ширине) - округло'Оленька' и 'Фемида' - продолговатая. эллиптическая ('Десертная Ранняя', Верхушка плода у исследуемых сортов, 'Обильная', 'Оленька', 'Фемида') и в основном, заостренная и плоская, удлиненно-эллиптическая ('Андрометолько у сорта 'Обильная' - вогнутая. да', 'Румяная Зорька'). Время цветения, Окраска кожицы плода - желтовато- как и время созревания плодов, у исслеоранжевая у сорта 'Румяная Зорька', дуемых сортов среднее и позднее. Прокрасная - у сорта 'Оленька', пурпурная веденные исследования подтверждают - у сорта 'Андромеда', фиолетово-синяя возможность уверенно отличать сортау сортов - 'Десертная Ранняя' и кандидаты от известных, широко вы'Обильная'. Сорт 'Фемида' выделяется ращиваемых сортов путем сравниватемно-синей окраской кожицы. Мякоть ния зарегистрированных описаний у всех шести исследуемых сортов - растений, размещенных рядом желтая (код степени проявления 2), ее «бок-о-бок». Визуальное сравнение плотность - средняя и плотная. Рыхлая «бок - о - бок» означает, что оценка отмякоть не выявлена. Размер косточки личимости основана на прямом визуплодов исследуемых сортов мелкий и альном сравнении сортов, которые рассредний, что с учетом крупного размера положены рядом или достаточно близплодов позволят увеличить выход мя- ко в каждом другом полевом испыта- 
нии. Признаки можно наблюдать визу- лены общие подходы в оценке отличиально или использовать индексы, кото- мости на основе полевого испытания, рыми выражаются те или иные свойства принимая во внимание метод размносортов, представлять простой записью жения, тип выраженности признака, (регистрацией). В таблице 3 представ- метод наблюдения и тип регистрации.

\section{Таблица 3. Общие подходы к оценке отличимости сортов гибридной алычи в полевых испытаниях на экспериментальных участках \\ Table 3. Common approaches to assessing the distinctness of the hybrid cherry plum varieties in field trials on the experimental field}

\begin{tabular}{l|l|l|l}
\hline \multirow{2}{*}{$\begin{array}{l}\text { Метод размножения } \\
\text { сорта }\end{array}$} & \multicolumn{3}{|c}{ ТL } \\
& качественный & \multicolumn{1}{|c}{$\begin{array}{c}\text { PQ } \\
\text { псевдокачественный }\end{array}$} & \multicolumn{1}{c}{ QN } \\
& количественный \\
\hline $\begin{array}{l}\text { Вегетативно размножа- } \\
\text { емый, } \\
\text { перекрестноопыляемый }\end{array}$ & $\mathrm{VG} /\left(\mathrm{VS}^{*}\right)$ & $\mathrm{VG} /\left(\mathrm{VS}^{*}\right)$ & $\mathrm{VS} / \mathrm{VG} / \mathrm{MS} / \mathrm{MG}$ \\
\hline
\end{tabular}

*Регистрации индивидуальных растений нужны, только если необходимо доказать отличие.

QL - качественные признаки, которые выражены в дискретных степенях (например, пол растения: двудомный женский, двудомный мужской, однодомный раздельнополый, однодомный обоеполый. Эти степени самоочевидны и независимо значимы. Все степени необходимы для описания всего диапазона выраженности признака и каждая выраженность может быть описана единственной степенью. Как правило, эти признаки не подвергаются воздействию окружающей среды.

QN - количественные признаки, их выраженность охватывает весь диапазон вариации, от одного экстремального значения до другого. Диапазон выраженности подразделяется на ряд степеней для целей описания (например, длина стебля: очень короткий, короткий, средний, длинный, очень длинный).

PQ - псевдокачественные признаки, диапазон их выраженности частично непрерывный, но варьирует более чем в одном измерении (например, форма: яйцевидная, эллиптическая, округлая, обратнояйцевидная) и не может адекватно описываться простым определением двух концов линейного диапазона. Каждая конкретная степень нуждается в идентификации для описания диапазона выраженности признака. V - визуальное наблюдение; М - измерение (использование линейки, весов, колориметра и т. д.); $\mathrm{G}$ - простая регистрация для группы растений или их частей; $\mathrm{S}-$ peгистрация индивидуальных растений или их частей.
Простая регистрация по группе растений или частей растений $(\mathrm{G})$. Если внутри сортов относительно небольшое варьирование (исключая нетипичные растения), в сравнении с варьированием между сортами, то степень выраженности признака может быть зарегистрирована как простая регистрация по группе растений или частей растений (G) при оценке отличимости. Регистрация $(\mathrm{G})$ может быть в виде: индексов (например, 1, 2, 3 и т. д.), соответствующих степени выраженности в Испытательных методиках УПОВ; оценки (например, RHS указания номера цветовой карты); измерения (например, длина (см), вес (г), дата (18-12-2015); подсчета; изображения и т. д.

Регистрация (G) может быть результатом наблюдения делянки в целом (например, окраска листа, время начала цветения), либо может быть результатом наблюдения в целом частей растений, взятых из группы растений (например, окраска нижней стороны листа).

Пример $(V G) . \quad$ Визуальное наблюдение(VG): «Цветок: размер» у алычи (размножаемой вегетативно): наблюдается и регистрируется соответствующая степень выраженности по сорту: индекс 3 (мелкий), индекс 5 (средний) или 7 (крупный);

$$
\text { Пример (VG). Визуальное }
$$
наблюдение (VG): «Плод: симметрия (вид спереди)» у алычи (перекрестноопыляемой): наблюдаются на плодах нескольких растений, и соответствующая степень выраженности регистрируется по 
сорту: индекс 1 (неравнобокий) или индекс 2 (равнобокий).

Родительская формула отражает разницу между родительскими линиями, что гарантирует отличимость гибрида, полученного от этих родителей. Оценку однородности сортов проводили на основе подсчета нетипичных растений. Выявление нетипичных растений осуществляли визуально. Растение считается нетипичным, если оно явно отличимо от сорта в

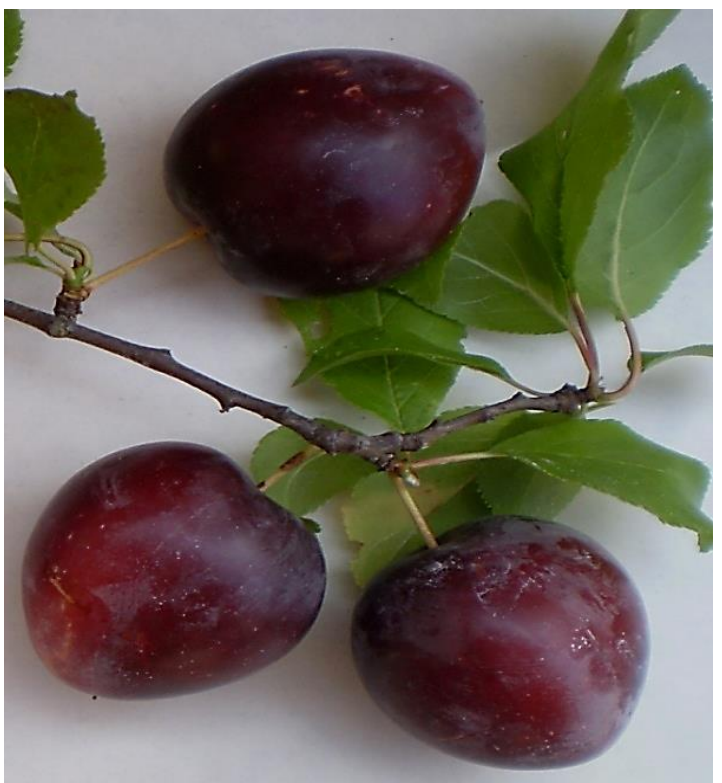

1

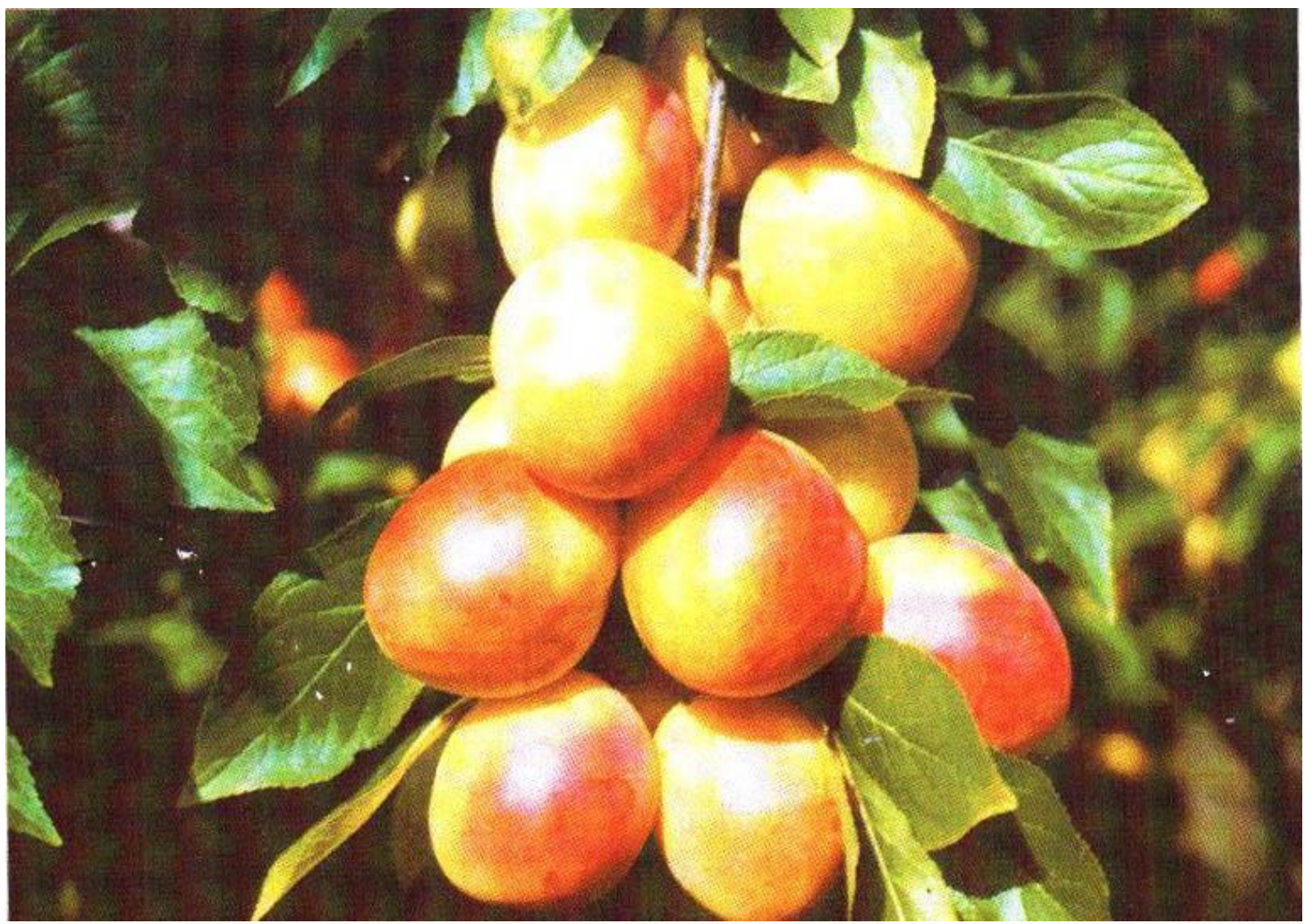

проявлении любого признака, используемого в испытании на отличимость, с учетом особенности его размножения. При оценке однородности стандарт отличимости между нетипичными растениями и сортом-кандидатом такой же, что и для отличимости между сортом-кандидатом и другими сортами. В проведенных многолетних исследованиях (5-20 лет) ни по одному сорту нетипичные растения не выявлены.

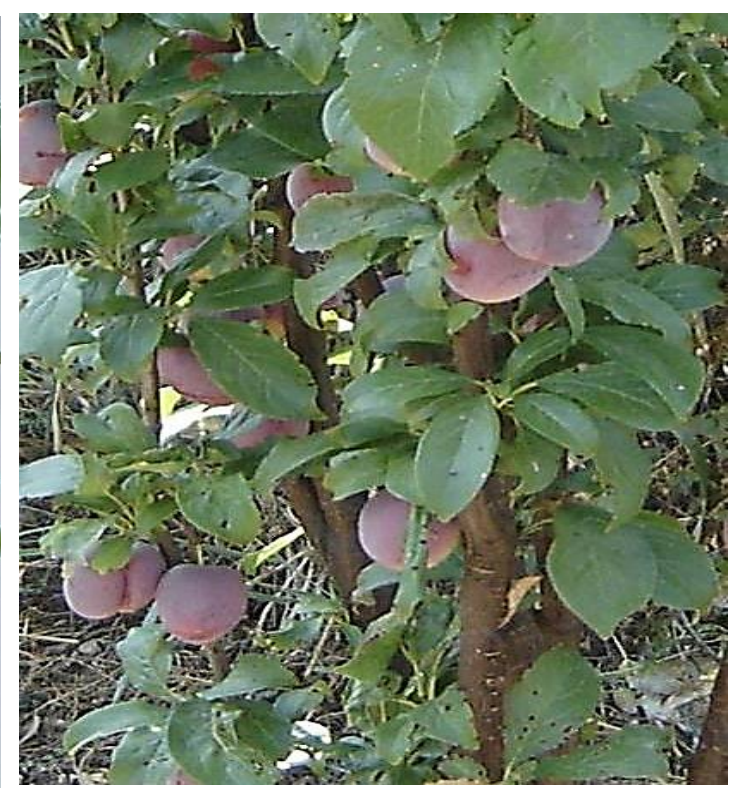

\section{2}




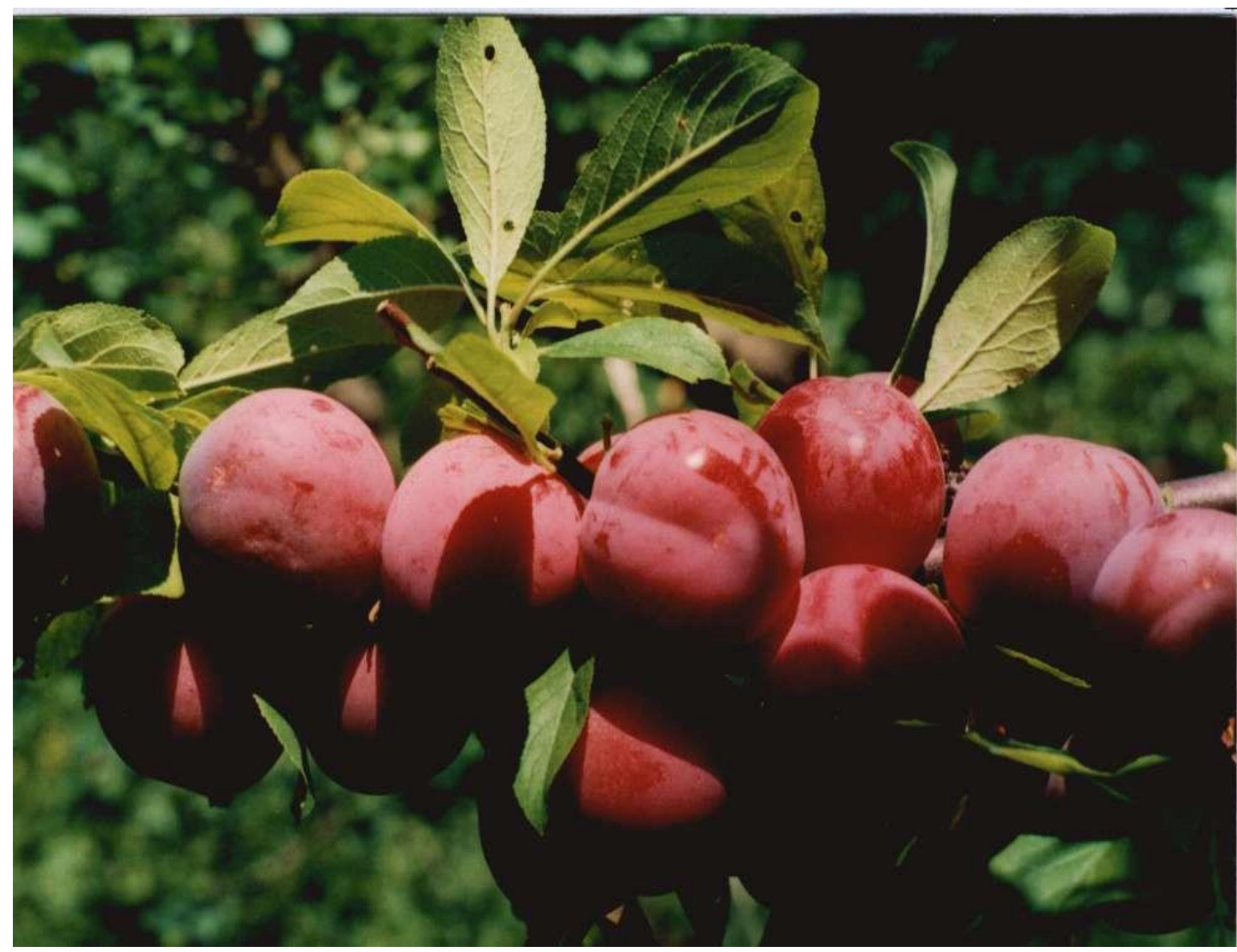

4

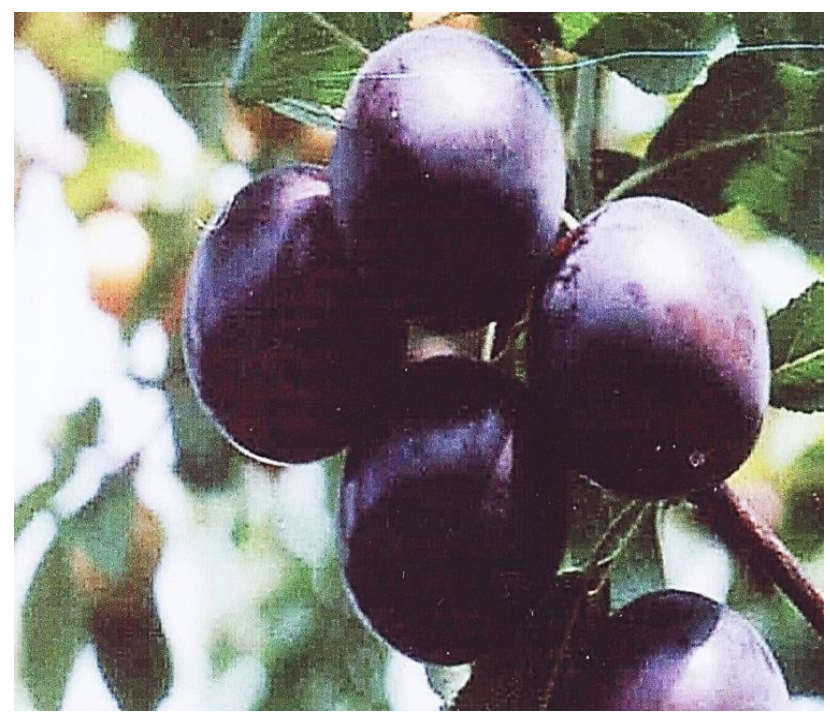

5

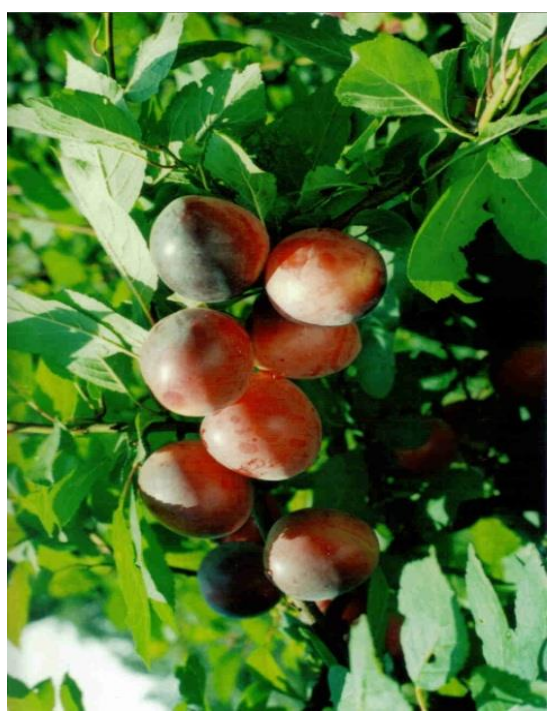

6

Сорта гибридной алычи селекции Никитского ботанического сада: 1 - 'Андромеда', 2 -

'Десертная Ранняя', 3 - 'Румяная Зорька', 4 - 'Обильная', 5 -‘Фемида', 6 -'Оленька'

The hybrid cherry plum varieties bred by NBG: 1 - 'Andromeda', 2 - 'Desertnaya Rannyaya', 3 'Rumyanaya Zor`ka', 4 - 'Obil 'naya', 5 - 'Femida', 6 - 'Olen`ka'

На практике обычно не проводят испытания стабильности, которые дают столь же определенные результаты, как при испытаниях на отличимость или однород- ность. На основе многолетних исследований показано, что сорт, проявляющий себя однородным, может быть признан и стабильным. Это указывает на то, что опреде- 
ление однородности и стабильности тесно взаимосвязаны. Если стабильность сорта вызывает сомнение, то необходимо сорт испытать путем выращивания последующего поколения, или же путем испытания новых семян или посадочного материала, что дает возможность удостовериться, что новый материал имеет такие же оценочные признаки, что и предыдущий. Ниже представлены фото сортов гибридной аычи селекции Никитского ботанического сада (рисунок).

\section{Выводы}

Таким образом, анализ результатов многолетних исследований морфологобиологических признаков шести сортов алычи позволил сделать вывод, что данные сорта удовлетворяют критериям отличительности, однородности и стабильности, о чем свидетельствуют заключения экспертов Госкомиссии по испытанию сортов.

\section{References/Литература}

Smykov V. K., Gorina V. M. Selection of plum in the southern area of horticulture // In: Intensification of breeding fruit crops / Ed. V.K. Smykov, A.I. Lischuk. Proceedings GNBS, Yalta, 1999, vol. 118, pp. 73-78 [in Russian] (Смыков В. К., Горина В. М. Селекция алычи в южной зоне садоводства // Интенсификация селекции плодовых культур / под ред. В.К. Смыкова, А.И. Лищука. Сб. научных трудов ГНБС. Ялта, 1999. T. 118. C. 73-78).

Eremin G. V. Plum and cherry-plum. Kharkov: Folio; Moscow: OOO "Izdatelstvo AST", 2003, 302 p. [in Russian] (Еремин Г. В. Слива и алыча. Харьков: Фолио; М.: ООО «Издательство АСТ», 2003. 302 с.).

Official website of State Organization "Russian State Committee on Testing and Protection of Selection Achievements". The RTG / 0084/1 document. Procedure icpytany for distinctness, uniformity and stability. Plum Chinese (Japanese) and other diploid species of plum (Prunus salicina Lindl.) №12-06 / 12 dated 27.05.1998. 10 p. [in Russian] (Официиальный сайт ФГБУ «Государственная комиссия Российской Федерации по испытанию и охране селекционных достижений». Документ RTG/0084/1. Методика проведения испытаний на отличимость, однородность и стабильность. Слива китайская (японская) и другие диплоидные виды сливы (Prunus salicina Lindl.) №12-06/12 от 27.05.1998 г. 10 c.).

Official website of State Organization "Russian State Committee on Testing and Protection of Selection Achievements". TGR / 9. Examining Distinctness. Geneva, 11 April 2008 (a) - 37p. [in Russian] (Официальный сайт ФГБУ «Государственная комиссия Российской Федерации по испытанию и охране селекционных достижений». Документ TGP/9. Экспертиза отличимости. Женева, 11 апреля 2008 г. (a), 37 с.).

Official website of State Organization "Russian State Committee on Testing and Protection of Selection Achievements". TGR / 10 Document.
Examining Uniformity. Geneva, 30 October 2008 (b), 15 p. [in Russian] (Официальный сайт ФГБУ «Государственная комиссия Российской Федерации по испытанию и охране селекционных достижений». Документ TGP/10. Экспертиза однородности. Женева, 30 октября 2008 г. (б). 15 с.).

Official site FGBU "State Commission of the Russian Federation with respect to $\mathrm{T} / 11$. Examination of stability. Geneva, 28 October 2008 (c) 6 p. [in Russian] (Официальный сайт ФГБУ «Государственная комиссия Российской Федерации по Т/11. Экспертиза стабильности. Женева, 28 октября 2008 г. (в). 6 с.).

Programme and methodology of researching cultivar fruit, berry and nut crops / ed. G.A. Lobanov. Michurinsk, 1973, 494 p. [in Russian] (Программа и методика сортоизучения плодовых, ягодных и орехоплодных культур / под ред. Г.А. Лобанова. Мичуринск, 1973. 494 с.).

Programme and methodology of researching cultivar fruit, berry and nut crops / ed. EN Sedov and TP Ogoltsovoy. Orel, 1999, 608 p. [in Russian] (Программа и методика сортоизучения плодовых, ягодных и орехоплодных культур / под ред. Е.Н. Седова и Т.П. Огольцовой. Орел, 1999. 608 c.).

Climatic Atlas of Crimea / Annex to scientific and practical debatable analytical collection "Problems of development of the Crimea." Simferopol: Tavria-Plus, 2000, 120 p. [in Russian] (Климатический атлас Крыма / Приложение к научно-практическому дискуссионному аналитическому сборнику «Вопросы развития Крыма». Симферополь: Таврия-Плюс, 2000. 120 c.).

Vazhov V. I. Agroclimatic zoning of Crimea // Soil and climatic resources of the Crimea and the rational distribution of fruit crops: Sat. scientific. works. Yalta, 1977, vol. 71, pp. 92-120 [in Russian] (Важов В. И. Агроклиматическое районирование Крыма // Почвенноклиматические ресурсы Крыма и рациональное размещение плодовых культур: сб. науч. трудов. Ялта, 1977. Т. 71. С. 92-120). 


\section{ИММУНИТЕТ КУАЬТУРНЫХ РАСТЕНИЙ И ИХ АИКИХ РОАИЧЕЙ}

\section{В. А. Бирюкова ${ }^{1}$, И. В. Шмыгля ${ }^{1}$, С. Б. Абросимова ${ }^{1}$, В. В. Мананков ${ }^{1}$, А. В. Митюшкин ${ }^{1}$, Е. В. Рогозина ${ }^{2}$, С. Д. Киру ${ }^{2}$, Н. А.Чалая', А. А. Мелешин ${ }^{1}$, B. А. Жарова ${ }^{1}$}

${ }^{1}$ Федеральное государственное бюджетное научное учреждение Всероссийский научноисследовательский институт картофельного хозяйства имени А. Г. Лорха 140051, Россия, Московская область, пос. Красково, ул. Лорха, д. 23 e-mail: vika_biruykova@inbox.ru

${ }^{2}$ Федеральный исследовательский центр Всероссийский институт генетических ресурсов растений имени Н. И. Вавилова, 190000 Санкт-Петербург, ул. Б. Морская д. 42, 44, Россия, e-mail: rogozinaelena@gmail.com

Ключевые слова: картофельная цистообразующая нематода, молекулярные маркеры, гены устойчивости, маркер опосредованная селекция (МОС)

Поступление:

10.12.2016

Принято:

06.03.2017

\section{ПРИМЕНЕНИЕ МОЛЕКУЛЯРНЫХ МАРКЕРОВ В СЕЛЕКЦИИ НА УСТОЙЧИВОСТЬ К КАРТОФЕЛЬНОЙ ЦИСТООБРАЗУЮЩЕЙ НЕМАТОДЕ}

Актуальность. Картофельные цистообразующие нематоды (КЦН) - являются объектами внешнего и внутреннего карантина растений. Выведение устойчивых сортов - основной способ борьбы с данными паразитами. Для повышения эффективности селекции на устойчивость к КЦН в последнее время широко используются молекулярные маркеры. Во Всероссийском научно-исследовательском институте картофельного хозяйства (ВНИИКХ) ДНК-маркеры генов устойчивости к КЦН применяются на разных этапах селекционных программ. Материал и методика. Проведен скрининг более 450 образцов из коллекций ВНИИКХ и Всероссийского института генетических ресурсов растений (ВИР) на устойчивость к КЦН с помощью классических и молекулярных подходов. Исследованы 57 образцов генетической коллекции ВИР; 144 образца из признаковых коллекций и 160 перспективных гибридов ВНИИКХ; более 90 генотипов из разных гибридных популяций. Результаты и выводы. Согласованность между результатами молекулярного анализа и фенотипической устойчивостью к нематоде составила для маркеров гена $H 1: 96 \%$ для 57R, 91\% для N146, 90\% для N195, 64\% для TG689 и для маркеров гена Grol4: $81 \%$ для Gro1-4 и 78\% для Gro1-4-1. Выявлены случаи с «ложноотрицательными» (когда есть устойчивость, и нет маркера) и «ложноположительными» (есть маркер, но нет устойчивости) результатами исследований. Наиболее эффективным маркером для селекции картофеля на устойчивость к Globodera rostochiensis (Woll.) Behrens является - 57R, характеризующийся высоким уровнем корреляции с признаком устойчивости к нематоде. Изучено наследование ДНК-маркеров генов Hl и Grol-4 в F1 поколении, полученном от разных комбинаций скрещивания. В потомстве как по гену H1, так и по гену Grol-4 наблюдалось расщепление 1:1. На основе маркер опосредованной селекции выделены гибриды картофеля, обладающие более высокой системой защиты к КЦН, - 2646-11, происхождение: 92.13-186 (Grol-4) × 91.30-66 [Россиянка (H1, Gpa2) × 88.34/14] и 1327-1, происхождение: Лира (Grol-4) × Raja (H1, Gpa2). Оба гибрида содержат по три гена - Hl, Grol-4, Gpa2 и являются источниками устойчивости к нескольким патотипам КЦН. 


\section{IMMUNITY OF CULTIVATED PLANTS AND THEIR WILD RELATIVES}

\section{A. Biryukova ${ }^{1}$ I. V. Smiglya ${ }^{1}$, S. B. Abrosimova ${ }^{1}$, V. V. Manankov', A. V. Mityushkin ${ }^{1}$, E. V. Rogozina ${ }^{2}$, S. D. Kiru' N. A. Chalaya ${ }^{2}$, A. A. Meleshin', V. A. Zharova ${ }^{1}$}

${ }^{1}$ A. G. Lorch All-Russian Institute of Potato Research, 23, Lorcha St., Kraskovo, Moscow region, 140051 Russia, e-mail: vika_biruykova@inbox.ru

${ }^{2}$ The N. I. Vavilov All-Russian Institute of Plant Genetic Resources, 42, 44, Bolshaya Morskaya str., St. Petersburg, 190000 Russia e-mail: rogozinaelena@gmail.com

Key words: potato cyst nematode, molecular markers, resistance gene, marker-mediated breeding

Received:

10.12.2016

Accepted: 06.03.2017
ORIGINAL ARTICLE

\section{APPLICATION OF MOLECULAR MARKERS IN BREEDING FOR RESISTANCE TO POTATO CYST NEMATODE}

Background. Potato cyst nematodes (PCN) are objects of external and internal plant quarantine. Breeding of resistant varieties is the basic way to control these pathogens. Of late, molecular markers have been widely used to improve the efficiency of breeding for resistance to PCN. At the All-Russian Institute of Potato Research DNA markers of PCN resistance genes are applied at different stages of breeding programs. Materials and methods. Screening of more than 450 accessions of genetic collections and promising hybrids from the AllRussian Institute of Potato Research and the Vavilov All-Russian Institute of Plant Genetic Resources for resistance to PCN has been carried out using classical and molecular approaches. The studied material included 57 accessions from the genetic collection of potato maintained at VIR, 144 accessions from the trait-targeted working collections, 160 promising hybrids from the Institute of Potato Research, and over 90 genotypes from various hybrid populations. Results and conclusions. Consistency between the results of molecular analysis and phenotypic resistance to the nematode was with the $H 1$ gene markers: $96 \%$ for $57 \mathrm{R}, 91 \%$ for $\mathrm{N} 146,90 \%$ for N195, and $64 \%$ for TG689; and with the Grol-4 gene markers: $81 \%$ for Gro1-4, and $78 \%$ for Gro1-4-1. There were identified cases of "pseudonegative" (when resistance exists, but there is no marker) and "pseudopositive" (there is a marker, but no resistance) research results. The most effective marker in potato breeding for resistance to Globodera rostochiensis (Woll.) Behrens is 57R characterized by a high level of correlation with the PCN resistance trait. Inheritance of DNA markers of the $\mathrm{Hl}$ and Grol-4 genes in $\mathrm{F}_{1}$ obtained from different crossing combinations was studied. Segregation in the progeny was 1:1 for both genes - HI and Grol-4. Such marker-mediated breeding process helped to identify potato hybrids with a stronger protection system against PCN: 2646-11 originated from 92.13-186 $($ Grol-4) $\times$ 91.30-66 [Rossiyanka $(H 1$, Gpa2) $\times$ 88.34/14], and 1327-1 originated from Lira (Grol-4) $\times$ Raja $(\mathrm{Hl}, \mathrm{Gpa} 2)$. Both hybrids contain all three genes - H1, Grol-4 and Gpa2 - and are sources of resistance to multiple PCN pathotypes. 


\section{Введение}

Картофельные цистообразующие нематоды (КЦН) - золотистая картофельная нематода Globodera rostochiensis (Woll.) Behrens и бледная картофельная нематода Globodera pallida (Stone) Behrens, которые включают восемь патотипов (Ro1-Ro5 и Pa1-Pa3), являются карантинными объектами и считаются наиболее вредоносными патогенами картофеля. Создание и возделывание сортов устойчивых к нематодам является одним из основных, экологически безопасных и экономически выгодных способов борьбы с ними. Успех селекции в этом направлении во многом зависит от изучения, подбора и систематизации исходного материала, мобилизации в селекционных программах культурных и дикорастущих видов Solanum L. - генетических источников устойчивости, создания на их основе эффективных доноров (межвидовых гибридов или предсортов), а также применения современных биотехнологий таких как маркер-опосредованная селекция (MOC), основанная на применении ДНКмаркеров тесно сцепленных с генами устойчивости. МОС на устойчивость к нематоде особенно актуальна, т. к. традиционная селекция, основанная на лабораторно-полевом тестировании образцов картофеля, является достаточно затратным и трудоемким процессом, требующим годы испытаний. Молекулярные маркеры значительно интенсифицируют поиск селекционно-ценных генотипов, позволяют существенно расширить выборку анализируемого материала и выявлять генотипы с комплексом генов устойчивости к КЦН (Gebhart et al., 2006). В результате исследований по картированию и секвенированию генома картофеля были разработаны молекулярные маркеры основных генов устойчивости к КЦН. Одним из первых был клонирован ген Grol, детерминирующий устойчивость ко всем тестируемым патотипам G. rostochiensis (Ro1, Ro2, R3, Ro4, Ro5) и интрогрессированный в сорта картофеля от гибрида культурного картофеля с видом $S$. spegazzinii Bitter $(2 \mathrm{n}=2 \mathrm{x}=24)$. На молекулярном уровне, локус Grol принадлежит к классу NB-LRR генов. Представитель этого семейства генов - Grol-4 - был отселектирован с помощью специфических праймеров (Gro1-4-маркер) (Gebhart et al., 2006). Наряду с Gro1-4 широкое применение в практической селекции получил SCAR-маркер TG689, сцепленный с локусом гена $H 1$, обеспечивающим защиту картофеля от золотистой картофельной нематоды (De Jong, неопубликованные данные). Пригодность маркеров Gro1-4 и TG689 для выявления генотипов устойчивых к $G$. rostochiensis подтверждена рядом независимых исследований (Biryukova et al., 2008; Galek et al., 2011; Milczarek et al., 2011). B целях оптимизации процедуры MOC D. Milczarek c соавторами (Milczarek et al., 2012) использовали метод мультиплексной ПЦР для обнаружения генов H1 и Grol-4 в одной ПЦР-реакции.

A. M. Finkers-Tomczak c соавторами (Finkers-Tomczak et al. 2011) сконструировали физическую карту области гена $H 1$ и успешно идентифицировали два SCARмаркера (57R и 110L), фланкирующие его локус. L. Shultz с соавторами (Shultz et al., 2012) на выборке более чем 300 генотипов картофеля показали, что 57R имеет хороший диагностический потенциал и является более надежным маркером по сравнению с TG689. K Mori с соавторами (Mori et al. 2011) предложили использовать набор двух ко-сегрегирующих маркеров N146 и N195, тесно сцепленных с геном Hl, а также внутригенные маркеры, непосредственно амплифицирующие участок гена Gpa2, контролирующего устойчивость к G. pallida (Mori et al., 2011). K. Asano с соавторами (Asano et al., 2012) на основе выравнивания нуклеотидных последовательностей Grol-4 и генов семейства Grol получили более специфический маркер - Gro1-4-1. Для удобства они разработали мультиплекс, включающий детекцию сразу трех генов: H1, Gro1-4, Gpa2.

MOC начиналась со всемирного скрининга родительских селекционных линий (Dalamu, 2012). Во Всероссийском научноисследовательском институте картофельно- 
го хозяйства (ВНИИКХ) молекулярные маркеры применяются: на этапе пребридинга для поиска источников устойчивости к КЦН, представляющих интерес в качестве исходного материала для дальнейшей селекции среди образцов генетических коллекции ВНИИКХ и Всероссийского института генетических ресурсов растений (ВИР); на этапе основного испытания для оценки перспективных гибридов картофеля, отобранных по другим хозяйственно ценным признакам; и на ранних этапах селекции для скрининга гибридных популяций с целью изучения закономерностей наследования молекулярных маркеров. В статье представлены результаты МOC на устойчивость к КЦН за 2009-2015 гг. Цель настоящей работы - провести сравнительную оценку эффективности использования в селекции картофеля различных молекулярных маркеров генов устойчивости к КЦН на образцах генетических коллекций и перспективных гибридах ВНИИКХ и ВИР.

\section{Материалы и методы}

В работе было исследовано более 450 генотипов картофеля, в том числе 144 образца из признаковых коллекций ВНИИКХ, включая гибриды-беккроссы, родительские линии и сорта, полученные на их основе; 37 сложных межвидовых гибридов и 20 форм видов Solanum из коллекции ВИР; 160 перспективных гибридов селекции ВНИИКХ, находящиеся на этапе основного испытания; более 90 генотипов из разных гибридных популяций. Молекулярногенетический анализ проводился на препаратах тотальной ДНК, выделенной из световых ростков клубней и листьев растений в полевых и in vitro коллекциях по протоколу, основанному на СТАВ-методе (SagaiMaroof, 1984). Для оценки генотипов использовались ДНК-маркеры устойчивости к золотистой картофельной нематоде $G$. rostochiensis - SCAR-маркеры гена Hl: TG689 (Galek et al., 2011), $57 \mathrm{R}$ (Shultz et al., 2012), N146 и N195 (Mori et al., 2011), SCAR-маркер Gro 1-4 (Gebhart, 2006) и STS-маркер Gro1-4-1 гена Grol-4 (Asano et al., 2012), STS-маркер Gpa2-2 гена Gpa2 (Asano et al., 2012).

В целях оптимизации процедуры МОС использовали серию трех мультиплексных ПЦР для детекции генов H1 и Grol-4, а также H1, Grol-4 и Gpa2. Нуклеотидные последовательности праймеров и условия индивидуальных ПЦР взяты из литературных источников и представлены в таблице 1. Амплификацию ДНК проводили в термоциклере PTC-100 (MJ Research, Inc., США). Стандартная реакционная смесь объемом 25 мкл содержала 10Х буфер для Таq ДНК-полимеразы (Синтол, Россия), 2,5 мM смесь dNTP (Хеликон, Россия), 25 мМ водный раствор хлорида магния (Fermentas, Литва), 5-10 пкмоль каждого праймера (Синтол, Россия), 0,5 е.a. Таq ДНКполимеразы (Синтол, Россия), 20 нг пробы ДНК и 13-10 мкл воды $\mu \mathrm{Q}$. Присутствие специфического фрагмента детектировали электрофоретическим разделением продуктов амплификации в 1,5\% агарозном геле, окрашенном бромистым этидием.

ВСН-маркер, амплифицирующий консервативный участок бетакаротингидроксилазы (Galek et al., 2011) и маркер GBSS1-3 гена GBSSI (ген waxy), контролирующего содержание амилопектина в крахмале (Mori et al., 2011), использовали как внутренний положительный контроль, свидетельству-ющий о качестве матрицы ДНК и о правильности проведения ПЦР. Для проверки ассоциации маркерпризнак мы сопоставили результаты молекулярного анализа с лабораторно-полевой оценкой образцов картофеля на устойчивость к золотистой картофельной нематоде методом искусственного заражения клубней, которая проводилась на базе «Всероссийского пункта по испытанию устойчивости сортов и гибридов картофеля к раку и картофельной нематоде» согласно методике (Volovik et al., 1995). Уровень корреляции между присутствием/отсутствием маркера и фенотипическим проявлением устойчивости у анализируемых образцов картофеля определяли с помощью коэффициента знаков Фехнера по формуле:

$$
\mathrm{K}_{\phi}=\left(\mathrm{n}_{\mathrm{a}}-\mathrm{n}_{\mathrm{b}}\right) /\left(\mathrm{n}_{\mathrm{a}}+\mathrm{n}_{\mathrm{b}}\right) \times 100 \%,
$$


где $\mathrm{n}_{\mathrm{a}}$ - число совпадений; $\mathrm{n}_{\mathrm{b}}$ - число не- устойчивым теоретически ожидаемому совпадений. Для оценки соответствия расщеплению в потомстве использовали наблюдаемого в гибридных популяциях критерий хи-квадрат. соотношения устойчивых генотипов к не-

Таблица 1. ДНК-маркеры генов устойчивости к картофельной цистообразующей нематоде (КцН)

Table 1. DNA markers of potato cyst nematode (PCN) resistance genes

\begin{tabular}{|c|c|c|c|c|}
\hline ПЦР & $\begin{array}{l}\text { Маркер } \\
\text { (тип / } \\
\text { ген) }\end{array}$ & $\begin{array}{c}\text { Нуклеотидная последовательность } \\
\text { праймеров }\left(5^{\prime} \rightarrow 3^{\prime}\right)\end{array}$ & $\begin{array}{c}\text { Размер } \\
\text { (пн) }\end{array}$ & Условия ПЦР \\
\hline \multirow{6}{*}{$\begin{array}{l}\text { Мультиплексная } \\
\text { ПЦР №1 }\end{array}$} & \multirow{2}{*}{$\begin{array}{l}\text { TG689 } \\
\text { (SCAR / } \\
\text { ген } H I)\end{array}$} & F: TAAAACTCTTGGTTATAGCCTAT & \multirow{2}{*}{141} & \multirow{6}{*}{$\begin{array}{c}3 \text { мин }-94^{\circ} \mathrm{C} \text {, далее } \\
35 \text { циклов: } 45 \mathrm{c}- \\
92^{\circ} \mathrm{C}, \quad 45 \mathrm{c}- \\
58^{\circ} \mathrm{C}, 1 \text { мин - } \\
72^{\circ} \mathrm{C} \text { и финальная } \\
\text { элонгация } 10 \text { мин - } \\
72^{\circ} \mathrm{C} \text { (Gebhardt et } \\
\text { al., 2006) }\end{array}$} \\
\hline & & $\begin{array}{c}\mathrm{R}: \\
\text { CAATAGAATGTGTTGTTTCACCAA }\end{array}$ & & \\
\hline & \multirow{2}{*}{$\begin{array}{c}\text { Gro1-4 } \\
\text { (SCAR / } \\
\text { ген } \\
\text { Gro1-4) } \\
\end{array}$} & F: TCTTTGGAGATACTGATTCTCA & \multirow{2}{*}{602} & \\
\hline & & R: CGACCTAAAATGAAAAGCATCT & & \\
\hline & \multirow{2}{*}{$\begin{array}{c}\mathrm{BCH} \\
(\mathrm{SCAR} / \\
\text { ген } B C H)\end{array}$} & $\begin{array}{c}\text { F: } \\
\text { CATGACATAGTTTGAATTTTGAGTC }\end{array}$ & \multirow[t]{2}{*}{290} & \\
\hline & & R: GCTTTGGCGCTGCCGTAAGTT & & \\
\hline \multirow{4}{*}{$\begin{array}{l}\text { Мультиплексная } \\
\text { ПЦР №2 }\end{array}$} & \multirow{2}{*}{$\begin{array}{c}57 \mathrm{R} \\
(\mathrm{SCAR} / \\
\text { ген } H 1)\end{array}$} & F: TGCCTGCCTCTCCGATTTCT & \multirow[b]{2}{*}{450} & \multirow{4}{*}{$\begin{array}{c}10 \text { мин }-95^{\circ} \mathrm{C}, \\
\text { далее } 30 \text { циклов: } \\
45 \mathrm{c}-95^{\circ} \mathrm{C}, 45 \mathrm{c}- \\
63^{\circ} \mathrm{C}, 45 \mathrm{c}-72^{\circ} \mathrm{C} \text { и } \\
\text { финальная элонга- } \\
\text { ция } \quad 10 \text { мин - } \\
72^{\circ} \mathrm{C} \\
\text { (Schultz et al., 2012) }\end{array}$} \\
\hline & & $\begin{array}{c}\text { R: } \\
\text { GGTTCAGCAAAAGCAAGGACGTG }\end{array}$ & & \\
\hline & \multirow{2}{*}{$\begin{array}{c}\mathrm{BCH} \\
(\mathrm{SCAR} / \\
\text { ген } B C H)\end{array}$} & $\begin{array}{c}\text { F: } \\
\text { CATGACATAGTTGAATTTTGAGTC }\end{array}$ & \multirow{2}{*}{290} & \\
\hline & & R: GCTTTGGCGCTGCCGTAAGTT & & \\
\hline \multirow{10}{*}{$\begin{array}{l}\text { Мультиплексная } \\
\text { ПЦР №3 }\end{array}$} & \multirow{2}{*}{$\begin{array}{l}\text { N146 } \\
\text { (SCAR / } \\
\text { ген } H 1)\end{array}$} & F: AAGCTCTTGCCTAGTGCTC & \multirow{2}{*}{506} & \multirow{10}{*}{$\begin{array}{c}10 \text { мин }-94^{\circ} \mathrm{C}, \\
\text { далее } 35 \text { циклов: } 30 \\
\mathrm{c}-94^{\circ} \mathrm{C}, \quad 30 \mathrm{c} \\
-60^{\circ} \mathrm{C}, 1 \text { мин - } \\
72^{\circ} \mathrm{C} \text { и финальная } \\
\text { элонгация } 5 \text { мин }- \\
72^{\circ} \mathrm{C} \text { (Asano et al., } \\
\text { 2012) }\end{array}$} \\
\hline & & R: AGGCGGAACATGCCATG & & \\
\hline & \multirow{2}{*}{$\begin{array}{l}\mathrm{N} 195 \\
(\mathrm{SCAR} / \\
\text { ген } H I)\end{array}$} & F: TGGAAATGGCACCCACTA & \multirow{2}{*}{337} & \\
\hline & & R: CATCATGGTTTCACTTGTCAC & & \\
\hline & \multirow{2}{*}{$\begin{array}{c}\text { Gro1-4-1 } \\
\text { (STS / } \\
\text { ген } \\
\text { Grol-4) }\end{array}$} & F: AAGCCACAACTCTACTGGAG & \multirow{2}{*}{602} & \\
\hline & & R: GATATAGTACGTAATCATGCC & & \\
\hline & \multirow{2}{*}{$\begin{array}{c}\text { Gpa2-2 } \\
\text { (STS / } \\
\text { ген } \\
\text { Gpa2-2) }\end{array}$} & F: GCACTTAGAGACTCATTCCA & \multirow{2}{*}{452} & \\
\hline & & R: ACAGATTGTTGGCAGCGAAA & & \\
\hline & \multirow{2}{*}{$\begin{array}{c}\text { GBSS1-3 } \\
\text { (STS / } \\
\text { ген } \\
\text { GBSS1) }\end{array}$} & F: AAAGGAGGCTCTTCAAGCAG & \multirow[b]{2}{*}{853} & \\
\hline & & R: TGCAAGAGCTCTAGCAACTG & & \\
\hline
\end{tabular}




\section{Результаты и обсуждение}

Ген $H 1$, интрогрессированный в большинство сортов от формы CРC 1673 S. andigenum Juz. et Buk., по результатам молекулярного скринирования идентифицирован у $85 \%$ устойчивых к G. rostochiensis образцов картофеля. Высокая частота встречаемости SCAR-маркеров гена HI связана с широким использованием клона $S$. andigenum в селекции картофеля, а также его генетической близостью к $S$. tuberosum по генам хозяйственно-ценных признаков и легкой скрещиваемостью (Rogozina, Kiru, 2005).

Наследование маркеров гена $H I$ в поколении $\mathrm{F}_{1}$ изучено на примере гибридных комбинаций 2652 [Малиновка (HI, Gpa2) × 93.20-12], 1647 [Felox $(H I) \times$ Ягодка] и 4421

[Roko (H1, Grol-4) × Русский сувенир], полученных от сортов картофеля устойчивых к G. rostochiensis (табл. 2). Несмотря на немногочисленное число проанализированных генотипов, во всех гибридных комбинациях наблюдается расщепление 1:1 (при $N=1, \mathrm{P}=0,05)$. Это указывает на то, что используемые в качестве родительских форм сорта 'Малиновка', 'Felox' и 'Roko' являются симплексами, т. е. содержат одну дозу или одну доминантную аллель гена H1. Достоверность соответствия результатов молекулярного скрининга теоретически ожидаемым данным подтверждается математически с помощью критерия хи-квадрат.

Таблица 2. Расщепление по устойчивости к картофельной цистообразующей нематоде (КЦН) в поколении $F_{1}$ различных родительских форм

Table 2. Segregation according to potato cyst nematode (PCN) resistance in $F_{1}$ obtained from different parental forms

\begin{tabular}{|c|c|c|c|c|c|c|c|}
\hline \multirow{3}{*}{$\begin{array}{l}\text { Происхожде- } \\
\text { ние популяции }\end{array}$} & \multirow{3}{*}{$\mathrm{N}$} & \multirow{3}{*}{\multicolumn{2}{|c|}{ Ген / Маркер }} & \multicolumn{4}{|c|}{$\begin{array}{c}\text { Отношение устойчивых генотипов к неустойчи- } \\
\text { вым }\end{array}$} \\
\hline & & & & \multicolumn{2}{|c|}{ по маркерам } & \multicolumn{2}{|c|}{ по фенотипу } \\
\hline & & & & & крите- & & \\
\hline \multirow{5}{*}{$\begin{array}{c}\text { Малиновка } \\
\text { (H1 Gpa2) } \times \\
93.20-12(2652)\end{array}$} & \multirow{5}{*}{$\begin{array}{l}2 \\
7\end{array}$} & \multirow{4}{*}{ H1 } & TG689 & $15: 12$ & 0,3320 & $14: 13$ & 0,0027 \\
\hline & & & $57 \mathrm{R}$ & $14: 13$ & 0,0027 & $14: 13$ & 0,0027 \\
\hline & & & N195 & $14: 13$ & 0,0027 & $14: 13$ & 0,0027 \\
\hline & & & N146 & $14: 13$ & 0,0027 & $14: 13$ & 0,0027 \\
\hline & & Gpa2 & Gpa2-2 & $19: 8$ & 0,3090 & - & - \\
\hline \multirow{4}{*}{$\begin{array}{l}\text { Felox }(\boldsymbol{H 1}) \times \\
\text { Ягодка }(1647)\end{array}$} & \multirow{4}{*}{$\begin{array}{l}3 \\
6\end{array}$} & \multirow{4}{*}{ H1 } & TG689 & $21: 15$ & 1,0000 & $22: 14$ & 1,7700 \\
\hline & & & $57 \mathrm{R}$ & $22: 14$ & 1,7700 & $22: 14$ & 1,7700 \\
\hline & & & N195 & $23: 13$ & 1,8000 & $22: 14$ & 1,7700 \\
\hline & & & N146 & $22: 14$ & 1,7700 & $22: 14$ & 1,7700 \\
\hline \multirow{6}{*}{$\begin{array}{c}\text { Roko (H1 } \\
\text { Gro1-4) × Рус- } \\
\text { ский сувенир } \\
(4421)\end{array}$} & \multirow{4}{*}{$\begin{array}{l}1 \\
9\end{array}$} & \multirow{4}{*}{$H 1$} & TG689 & $10: 9$ & 0,5200 & $12: 7$ & 1,3200 \\
\hline & & & $57 \mathrm{R}$ & $11: 8$ & 0,4700 & $12: 7$ & 1,3200 \\
\hline & & & N195 & $11: 8$ & 0,4700 & $12: 7$ & 1,3200 \\
\hline & & & N146 & $11: 8$ & 0,4700 & $12: 7$ & 1,3200 \\
\hline & \multirow[b]{2}{*}{$\begin{array}{l}1 \\
7\end{array}$} & \multirow[b]{2}{*}{$\begin{array}{c}\text { Gro1- } \\
4\end{array}$} & Gro1-4 & $9: 8$ & 0,0590 & $10: 7$ & 0,5300 \\
\hline & & & $\begin{array}{c}\text { Gro1-4- } \\
1\end{array}$ & $9: 8$ & 0,059 & $10: 7$ & 0,5300 \\
\hline \multirow{2}{*}{$\begin{array}{c}\text { Assia (Gro1-4) } \\
\times 88.16 / 20 \\
(101)\end{array}$} & \multirow[b]{2}{*}{$\begin{array}{l}5 \\
5\end{array}$} & \multirow[b]{2}{*}{$\begin{array}{c}\text { Gro1- } \\
4\end{array}$} & Gro1-4 & $29: 26$ & 0,8 & $24: 31$ & 1,3400 \\
\hline & & & $\begin{array}{c}\text { Gro1-4- } \\
1\end{array}$ & $29: 26$ & 0,8 & $24: 31$ & 1,3400 \\
\hline
\end{tabular}


Известно, что ген $H 1$, обеспечивает резистентность только к двум патотипам Ro1 и Ro4 G. rostochiensis, тогда как селекция на устойчивость направлена на защиту картофеля против всевозможных популяций нематоды. Поэтому интерес для селекционеров представляют образцы картофеля, у которых детектируются маркеры другого доминантного гена Grol-4, контролирующего устойчивость к пяти патотипам (Ro1Ro5) G. rostochiensis. В результате молекулярного анализа с учетом родословных изученных генотипов картофеля установлено, что источником гена Grol-4 среди образцов генетических коллекций ВНИИКХ является форма $S$. chacoense Bitter 58 d-22, полученная от самоопыления S. chacoense к-3693 (поступивший в ВИР как S. commersonii Dun.) (рисунок). С участием диплоидной формы дикого вида $S$. chacoense получен амфидиплоид $S$. vernei Bitt. et Wittm. $($ к-5428) $\times$ S. chacoense $58 \mathrm{~d}-$ 22 , от которого происходят нематодоустойчивые формы 591m-29 и 655 m-30 (см. рисунок), ставшие родоначальниками популяции $92.13($ Ресурс $\times 655 \mathrm{~m}-30)$ и сортов 'Брянский деликатес', 'Слава Брянщины' (Yashina, 2003). Маркеры гена Grol-4 обнаружены у форм видов $S$. yungasense Hawkes (к-2820), S. dolichostigma Buk. nom. nud. (к7613), S. × sucrense Hawkes (к-23599), S. vernei Bitter et Wittm. ex Engl. (к-10554), $S$. gourlayi Hawkes (к-23342), S. leptophyes Bitter (к-5764) из коллекции ВИР (Chalaya et al., 2012), а также у сорта 'Лира' селекции ВНИИКХ, содержащего генетический материал $S$. acaule Bitter, и иностранного copта 'Alwara', широко используемого в качестве материнского компонента скрещивания в селекционных программах ВНИИКХ. Образцы $S . \times$ doddsii Corr. (к-19817, ВИР) и S. sparsipilum (Bitter) Juz. et Buk. (к-20700, ВИР) содержат только Gro1-4. Для изучения процесса интрогрессии маркеров гена Grol-4 от устойчивых форм в поколении гибридов $\mathrm{F}_{1}$ была получена модельная популяция от сорта 'Assia' (источник гена Grol-4) из коллекции ВИР и неустойчивого к нематоде гибрида 88.16/20. В целом, распределение устойчивых и неустойчивых к G. rostochiensis форм по фенотипу (24:31) и по ДНК-маркерам (29:26) значимо не раз- личалось на уровне $<5 \%$ по критерию хиквадрат (см. табл. 2). Однако в результате молекулярного анализа были обнаружены восприимчивые к нематоде генотипы картофеля, содержащие маркеры Gro1-4 и Gro1-4-1 («ложноположительные» результаты). Для подтверждения специфичности маркеров гена Grol-4 требуется проведение дополнительных исследований по их верификации. На территории РФ распространен патотип Ro1 G. rostochiensis, но из-за регулярного ввоза семенного картофеля из стран Западной Европы нельзя исключать возможность случайной интродукции более агрессивного вида $G$. pallida. Поэтому большое внимание уделяется созданию сортов резистентных к широкому спектру патотипов обоих видов нематоды. Частичная устойчивость к $G$. pallida (популяции $\mathrm{Pa} 2$ и $\mathrm{Pa} 3)$ детерминируется доминантным геном Gpa2, источником которого, как и для гена $H 1$, является $S$. andigenum (главным образом СРС 1673-20). Хотя селекция на устойчивость к бледной картофельной нематоде специально не проводится, STSмаркер Gpa2 детектирован у 16\% образцов генетических коллекций и перспективных гибридов ВНИИКХ и ВИР. Маркерные технологии позволяют идентифицировать устойчивые по фенотипу растения, у которых резистентность к КЦН, контролируется несколькими генами от разных источников, обеспечивающими более надежную и продолжительную защиту. Комбинация двух генов устойчивости выявлена у $10 \%$ генотипов картофеля (табл. 3). Среди сортов отечественной селекции комплексная устойчивость к нематоде отмечена у сорта 'Кумач' (ВНИИКХ). Гибриды 2646-11 происхождение: 92.13-186 (Grol-4) × 91.3066 [Россиянка $(H 1$, Gpa2) × 88.34/14], и 1327-1 - происхождение: Лира (Grol-4) × Raja (Hl, Gpa2), по результатам MOC, содержат гены H1, Grol-4, Gpa2 и являются источниками устойчивости к нескольким патотипам КЦН. Использование различных SCAR-маркеров гена $H 1$ для изучения образцов генетических коллекций и перспективных гибридов позволило провести сравнительную оценку их диагностического потенциала как предикторов устойчивости к G. rostochiensis. Все четыре маркера 
TG689, 57R, N146 и N195 присутствовали у $78 \%$ генотипов картофеля, содержащих ген H1. Сопоставление данных о присутствии/отсутствии маркерных компонентов с фенотипической оценкой на устойчивость у разных форм картофеля выявило случаи с «ложноотрицательными» (когда есть устойчивость и нет маркера) и «ложноположительными» (есть маркер, но нет устойчивости) результатами исследований (табл.
4). По результатам предварительного испытания в лабораторных условиях, гибриды картофеля селекции ВНИИКХ - 4644-26 $($ Любава $\times$ Felox), 4422-7 (Romanze $\times$ Pусский сувенир), 4421-1 (Roko $\times$ Русский сувенир), и гибрид ВИР 99-6-6 (90-6-2 × Hertha) отнесены к числу «устойчивых» генотипов, однако молекулярные маркеры генов H1 и Grol-4 у них не обнаружены.

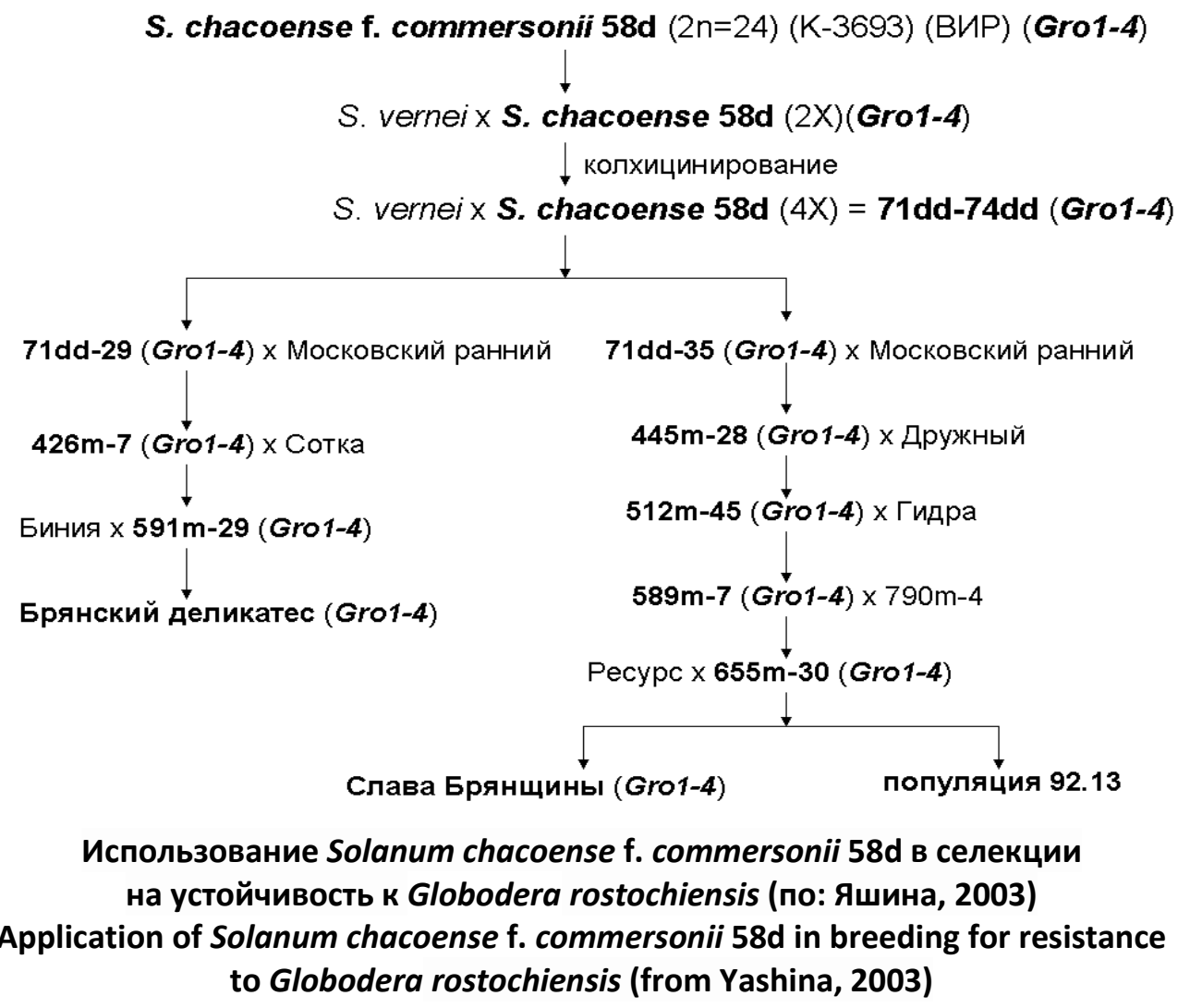

Отсутствие специфических маркерных компонентов у таких форм картофеля, может быть связано с плохо состоявшимся процессом заражения, наибольшее влияние на который оказывает температурный фактор, а также группа спелости (возраст) и физиологическое состояние тестируемых генотипов. Зависимость фитопатологической оценки от условий среды снижает объективность уровня корреляции между наличием маркера и фенотипической устойчивостью к нематоде. Лабораторное тестирование проводится весной, когда при благоприятных условиях картофель начинает продуцировать стимулирующие корневые выделения, активирующие содержа- ние цисты и способствующие вылуплению личинок. У средне- и позднеспелых сортообразцов и гибридов картофеля рост корней и световых ростков (прорастающих глазков) происходит медленнее, что сказывается на коэффициенте размножения нематоды, т. к. на более слабой корневой системе развивается лишь незначительное количество цист (Decker, 1972). Все вышеперечисленные генотипы картофеля являются среднеспелыми, что подтверждает возможность несостоявшегося процесса заражения нематодой. Для получения более объективных результатов лабораторно-полевую оценку на устойчивость к ЗКН проводят в течение нескольких лет и, как правило, при 
повторном тестировании часть таких N195 являются ко-сегрегирующими (Mori «устойчивых» образцов может поражаться et al., 2011) и детектируются совместно у G. rostochiensis. Наиболее высокий уровень большинства резистентных образцов карассоциации маркер-признак отмечен для тофеля. Исключением является гибрид маркера 57R, характеризующегося 2646-5, у которого идентифицирован тольнаименьшим количеством несовпадений с ко N146. Уникальная комбинация из двух фенотипической устойчивостью генотипов маркеров гена $H 1$ - TG689 и 57R выявлена картофеля. Молекулярные маркеры N146 и у гибрида 1608-10 (2323-26 × Наяда).

Таблица 3. Генотипы с комплексом генов устойчивости к картофельной цистообразующей нематоде (КцН)

по результатам маркер-опосредованной селекции (МOC)

Table 3. Genotypes with a set of potato cyst nematode (PCN) resistance genes identified in the marker-mediated breeding process

\begin{tabular}{|c|c|}
\hline Комбинация генов & Генотипы \\
\hline H1, Grol-4, Gpa2 & 1327-1 (Лира × Raja); 2646-11 (92.13-186 × 91.30-66) \\
\hline H1, Grol-4 & $\begin{array}{l}\text { 2643-7, 2643-12 (Слава Брянщины × 92.4-75); 2513-5, 2513-53 (Лира } \\
\times \text { Ausonia); 93.13-213, 93.12-212 (Жуковский ранний × 655m-30); } \\
\text { 2646-7 (92.13-186 × 91.30-66); сорт Кумач [У дача × Гранат (Бело- } \\
\text { руссия)]; 4421-12, 4704-61 (Roko × Русский сувенир); 4434-1 (Roko } \\
\times \text { Аврора); 1608-10 (2323-26 × Наяда); 1575-3, 1575-7, 1575-18 } \\
(\text { Arosa × Наяда) }\end{array}$ \\
\hline$H 1$, Gpa2 & $\begin{array}{l}\text { 134-6-2006 (создан в ВИР); 135-2-2006 (создан в ВИР); 1370-33 } \\
(\text { Лира × Ausonia); 1604-2 (96.5-7 × Maestro); 1658-5, 1658-10, 1658- } \\
20,1658-23 \text { (Kaskar × 1275-5); 4518-4 (Крепыш × Наяда); 4578-2 } \\
(\text { Courage } \times \text { Дубрава); 2658-3, 2658-8, 2658-10, 2658-12, 2658-15, } \\
2658-16,2658-19,2658-30,2658-31 \text { (Малиновка × 93.20-12); 2607-94 } \\
(\text { Елизавета × Пушкинец); 4062-2, 4062-5 (707-4 × Шурминский); } \\
\text { 4738-5 (Никулинский } \times \text { Ausonia) }\end{array}$ \\
\hline Grol-4, Gpa2 & 2646-13 (92.13-186 × 91.30-66); 4707-38 (Альвара × 88.17/72) \\
\hline
\end{tabular}

Однако, сложно правильно интерпретировать наличие маркеров с результатами фитопатологической оценки для этого генотипа картофеля, поскольку вклад в его устойчивость кроме $H 1$ вносит другой ген - Grol-4. Присутствие TG689 и N195 при отсутствии других маркеров у восприимчивых генотипов картофеля («ложноположительные» случаи) связано с их недостаточной специфичностью по отношению к гену H1. «Ложноположительные» результаты молекулярного анализа для гибрида картофеля 4609-14 (Колобок $\times$ Аврора) и сорта 'Тулеевский', содержащих по четыре и три маркера гена $H l$, соответственно, (табл. 5), связаны с несовершенством существующей в РФ шкалы оценки, согласно которой, устойчивыми являются формы с полным отсутствием цист на корнях растений. Поэтому большинство слабопоражаемых сортов отечественной селекции, входящие в Госреестр, считаются неустойчивыми. Однако в процессе оценки при искусственном заражении часть гибридов отличается замедленной реакцией сверхчувствительности, в результате которой на корнях таких растений формируется от 1 до 10 цист на корневой ком. Причем скорость реакции сверхчувствительности зависит от условий проведения заражения и может варьировать год от года. В отдельные годы фитопатологических испытаний реакция быстрая, и цист на корнях не образуется совсем. В потомстве родителей, обладающих замедленной реакцией сверхчувствительности, могут появляться гибриды с бо- 
лее быстрой реакцией, и наоборот, слабо- исследование причин появления генотипов восприимчивые гибриды - в потомстве от с замедленной реакцией сверхчувствительустойчивых родителей. Возникает целесо- ности. До настоящего времени еще не выобразность внесения изменений в «Поло- яснено наличие или отсутствие корреляций жение о порядке испытания картофеля на между скоростью реакции и уровнем эксустойчивость к возбудителю рака картофе- прессии доминантных генов, как это ля (патотип I) и золотистой картофельной наблюдается в отношении сверхчувствицистообразующей нематоде (патотип Ro1)» тельности $R$-генов $\quad$ к $\quad$ фитофторозу. (Regulation..., 1993). Важно продолжать

Таблица 4. Наличие (присутствие/отсутствие) маркеров устойчивости к Globodera rostochiensis у генотипов картофеля

Table 4. Presence/absence of Globodera rostochiensis resistance markers in potato genotypes

\begin{tabular}{|c|c|c|c|c|c|c|}
\hline \multirow{2}{*}{\multicolumn{2}{|c|}{$\begin{array}{c} \\
\text { Присутствие/отсутствие марке- } \\
\text { ра (1/0) }\end{array}$}} & \multicolumn{3}{|c|}{ Фенотип } & \multirow{4}{*}{$\begin{array}{c}\mathrm{N} \\
349\end{array}$} & \multirow{3}{*}{$\begin{array}{c}\text { Уровень ассо- } \\
\text { циации мар- } \\
\text { кер-признак } \\
\mathrm{K}_{\phi} \\
64 \%\end{array}$} \\
\hline & & $\mathrm{R}(\mathrm{SS})$ & $S$ & $\mathrm{R}(\mathrm{SS})+\mathrm{S}$ & & \\
\hline \multirow{2}{*}{ TG689 (ген Н1) } & 1 & 164 & 12 & 176 & & \\
\hline & 0 & 50 & 123 & 173 & & \\
\hline \multirow{2}{*}{ 57R (ген H1) } & 1 & 202 & 1 & 203 & \multirow{2}{*}{349} & \multirow{2}{*}{$96 \%$} \\
\hline & 0 & 12 & 134 & 146 & & \\
\hline \multirow{2}{*}{ N146 (ген H1) } & 1 & 199 & 1 & 200 & \multirow{2}{*}{349} & \multirow{2}{*}{$91 \%$} \\
\hline & 0 & 15 & 134 & 149 & & \\
\hline \multirow{2}{*}{ N195 (ген Н1) } & 1 & 200 & 4 & 204 & \multirow{2}{*}{349} & \multirow{2}{*}{$90 \%$} \\
\hline & 0 & 14 & 131 & 145 & & \\
\hline \multirow{2}{*}{ Gro1-4 (ген Gro1-4) } & 1 & 87 & 6 & 93 & \multirow{2}{*}{157} & \multirow{2}{*}{$81 \%$} \\
\hline & 0 & 9 & 55 & 64 & & \\
\hline \multirow{2}{*}{ Gro1-4-1 (ген Gro1-4) } & 1 & 85 & 6 & 91 & \multirow{2}{*}{157} & \multirow{2}{*}{$78 \%$} \\
\hline & 0 & 11 & 55 & 66 & & \\
\hline
\end{tabular}

Условные обозначения: R - устойчивые генотипы, SS - слабовосприимчивые генотипы, S - восприимчивые генотипы; $\mathrm{N}$ - общее число проанализированных генотипов.

\section{Выводы}

Скрининг более 450 образцов генетических коллекций и перспективных гибридов ВНИИКХ и ВИР позволил выявить недостатки и преимущества использования молекулярных маркеров в селекции картофеля на устойчивость к картофельной цистообразующей нематоде (КЦН). Наиболее эффективным по результатам исследований является маркер 57R гена $H 1$, характеризующийся высоким уровнем корреляции маркер-признак. Установлено, что случаи несовпадения результатов молекулярного анализа с фенотипической устойчивостью образцов картофеля связаны не только со специфичностью используемых маркеров, но и с недостаточной объективностью лабораторно-полевого испытания, влияние на которое оказывают внешние факторы, а 
также с несовершенством используемой в лекций ВНИИКХ и ВИР выделены новые РФ шкалы оценки на устойчивость к нема- источники устойчивости к КЦН и генотипы тоде. В результате маркер опосредованной с комплексом генов, представляющие интеселекции среди образцов генетических кол- рес для дальнейшей селекции

\section{Таблица 5. Результаты оценки на устойчивость к Globodera rostochiensis для некоторых генотипов картофеля. \\ Table 5. Results of the evaluation of some potato genotypes for their resistance to Globodera rostochiensis}

\begin{tabular}{|c|c|c|c|}
\hline $\begin{array}{c}\text { название сорта или гибри- } \\
\text { да }\end{array}$ & оценка по фенотипу & число цист & $\begin{array}{c}\text { присутствие ДНК- } \\
\text { маркеров генов } \\
\text { устойчивости }\end{array}$ \\
\hline \multirow{2}{*}{ Тулеевский } & восприимчив & $5,7,10$ & 57R, N146 и N195 \\
\hline & слабовосприимчив & $0,3,0$ & 57R, N146 и N195 \\
\hline Даренка & слабовосприимчив & $0,1,1$ & $\begin{array}{c}\text { TG689, 57R, N146 и } \\
\text { N195 }\end{array}$ \\
\hline 1604-22 (96.5-7 × Maestro) & слабовосприимчив & $0,0,1,2$ & $\begin{array}{c}\text { TG689, 57R, N146 и } \\
\text { N195 }\end{array}$ \\
\hline $\begin{array}{c}\text { 2643-1 (Слава Брянщины × } \\
\text { 92.4-75) }\end{array}$ & слабовосприимчив & $5,0,1$ & Gro1-4, Gro1-4-1 \\
\hline 2747-19 (Вектор × Romanze) & слабовосприимчив & $0,3,0$ & $\begin{array}{c}\text { TG689, 57R, N146 и } \\
\text { N195 } \\
\end{array}$ \\
\hline $\begin{array}{c}2646-13(92.13-186 \times 91.30- \\
66)\end{array}$ & слабовосприимчив & $3,1,0$ & Gro1-4, Gro1-4-1 \\
\hline 4609-14 (Колобок × Аврора) & восприимчив & $10,0,0$ & $\begin{array}{l}\text { TG689, 57R, N146 и } \\
\text { N195 }\end{array}$ \\
\hline 2670-23 (2308-11 × Талисман) & слабовосприимчив & $5,6,0$ & $\begin{array}{c}\text { TG689, 57R, N146 и } \\
\text { N195 }\end{array}$ \\
\hline $\begin{array}{c}\text { 4731-98 (Табор × Брянский } \\
\text { надежный) }\end{array}$ & слабовосприимчив & $7,0,0$ & $\begin{array}{c}\text { TG689, 57R, N146 и } \\
\text { N195 }\end{array}$ \\
\hline $\begin{array}{c}\text { 4738-11 (Никулинский } \times \\
\text { Ausonia) }\end{array}$ & слабовосприимчив & $2,5,0$ & $\begin{array}{c}\text { TG689, 57R, N146 и } \\
\text { N195 }\end{array}$ \\
\hline 4440-7 (Kaskar × Ausonia) & слабовосприимчив & $0,0,2$ & $\begin{array}{c}\text { TG689, 57R, N146 и } \\
\text { N195 }\end{array}$ \\
\hline
\end{tabular}

\section{References/Литература}

Asano K., Kobayashi A., Tsuda S., Nishinaka M., Tamiya $S$. DNA marker assisted evaluation of potato genotypes for potential resistance to potato cyst nematode pathotypes not yet invading into Japan // Breed. Sci., 62, 2012, pp. 142-150.

Biryukova V. A., Zhuravlev A. A., Abrosimova S. B., Kostina L. I., Khromova L. M., Shmyglya I. V., Morozova N. N., Kirsanova S. N. Use of molecular markers of potato golden nematode resistance genes $\mathrm{Hl}$ and Grol. // Russ. Agric. Sci. 34, 2008, pp. 365-368 [in Russian] (Бирюкова В. А., Журавлев А. А., Абросимова С. Б., Костина Л. И., Хромова Л. М., Шмыгля И. В., Морозова Н. Н., Кирсанова С. Н. Использование молекулярных маркеров генов $H 1$ и Grol устойчивости к золотистой картофель- ной нематоде. // Российская сельскохозяйственная наука (Доклады Российской академии сельскохозяйственных наук). 2008. № 6. C. 3-6).

Chalaya N. A., Biryukova V. A., Kiru S. D. New sources of resistance to the golden potato cyst nematode (G. rostochiensis Woll.) from the collection of wild potato species of the VIR. // Izvestiya of the St. Petersburg Agrarian University, 2012, no. 26, pp. 45-50 [in Russian] ( Чaлая Н. А., Бирюкова В. А., Киру С. Д. Новые источники устойчивости к золотистой картофельной нематоде (G. rostochiensis Woll.) из коллекции дикорастущих видов картофеля ВИР // Известия Санкт-Петербургского 
аграрного университета. 2012. № 26. С. 45$50)$.

Dalamu Bhardwaj V., Umamaheshwari R., Sharma R., Kaushik S. K., Joseph T. A., Singh B. P., Gebhardt $C$. Potato cyst nematode (PCN) resistance: genes, genotypes and markers - an update. // SABRAO Journal of Breeding and Genetics, 2012, 44 (2), pp. 202-228.

Decker H. Plant nematodes and their control. Moscow: «Kolos», 1972, 444 p. [in Russian] (Деккер X. Нематоды растений и борьба с ними. М.: «Колос», 1972. 444 с.).

Finkers-Tomczak A. M., Bakker E., de Boer J., van der Vossen E., Achenbach U., Golas T., Suryanigrat S., Smant G., Bakker J., Goverse A. Comparative sequence analysis of the potato cyst nematode resistance locus $H 1$ reveals a major lack of co-linearity between three haplotypes in potato (Solanum tuberosum ssp.) // Theor. Appl. Genet., 2011, 122, pp. 595-608.

Galek R., Rurek M., De Jong W. S., Pietkiewicz G., Augustyniak H. C., Sienkiewicz E. S. Application of DNA markers linked to the potato $H 1$ gene conferring resistance to pathotype Ro1 of Globodera rostochiensis. // J. Appl. Genet., 2011, 52, pp. 407-411.

Gebhardt C., Bellin D., Henselewski H., Lehmann W., Schwarzfischer J., Valkonen J. P. Marker assisted combination of major genes for pathogen resistance in potato // Theor. Appl. Genet., 2006, 112, pp. 1458-1464.

Milczarek D. A. Multiplex PCR Method of Detecting Markers Linked to Genes Conferring Resistance to Globodera rostochiensis // Am. J. Potato Res., 2012, 88, pp. 245-255.

Milczarek D., Flis B., Przetakiewicz A. Suitability of molecular markers for selection of potatoes resistant to Globodera ssp. // Am. J. Potato Res., 2011, 88, pp. 245-255.

Mori K., Sakamoto Y., Mukojima N., Tamiya S., Nakao T., Ishii T., Hosaka K. Development of a multiplex PCR method for simultaneous detection of diagnostic DNA markers of five disease and pest resistance genes in potato // Euphytica 180, 2011, pp. 347-355.

Rogozina E. V., Kiru S. D. Donors potato resistance to pathogens and product quality // In: Identified plant genepool and breeding. St. Petersburg,
2005, pp. 443-470 [in Russian] (Рогозина E. $B$, Киру C. Д. Доноры устойчивости картофеля к патогенам и качеству продукции // В кн.: Идентифицированный генофонд растений и селекция. СПб., 2005. С. 443-470).

Sagai-Maroof M. A., Soliman K. M., Jorgensen R. A., Allard R. W. Ribosomal dNA spacer-length polymorphism in barley: mendelian inheritance, chromosomal location, and population dynamics // Proc. Nat. Acad. Sci. USA, 1984, 81, pp. 8014-8018.

Schultz L., Cogan N. O. I., McLean K., Dale M. F. B., Bryan G. J., Forster J. W., Slater A. T. Evaluation and implementation of a potential diagnostic molecular marker for $\mathrm{Hl}$-conferred potato cyst nematode resistance in potato (Solanum tuberosum L.) // Plant Breed., 2012, 131, pp. 315-321.

Volovik A. S., Trofimets L. N., Dolyagin A. B., Glez $V$. M. Methods for the research of potato protection on diseases, pests, weeds and immunity. Moscow: VNIIKH, 1995, 105 p. [in Russian] (Воловик А. С., Трофимеи Л. Н., Долягин А. Б., Глез В. М. Методика исследований по защите картофеля от болезней, вредителей, сорняков и иммунитету. М.: ВНИИКХ, 1995. 105 c.).

Yashina I. M. Methodological instructions for process control technology introgression of genes from wild potato species in breeding varieties and hybrids. Moscow: Academy of Agricultural Sciences, 2003. 32 p. [in Russian] (Яшина И. $M$. Методические указания по технологии управления процессом интрогрессии ценных генов от диких видов картофеля в селекционные сорта и гибриды. М.: РАСХН, 2003. 32 c.).

Regulation on the procedure of testing of genotypes for resistance to the wart of potato (patotype I) and Golden potato cyst nematode (patotype I): utv. M-vom sel. khoz-va RF 17.03.1993. Moscow, 1993, 10 p. [in Russian] (Положение о порядке испытания картофеля на устойчивость к возбудителю рака картофеля (патотип I) и золотистой картофельной нематоде (патотип I): утв. М-вом сел. хоз-ва РФ 17.03.1993. М., 1993. 10 с.) 


\section{ИСТОРИЯ АГРОБИОАОГИЧЕСКИХ ИССАЕАОВАНИЙ И ВИР. С ААВНЫЕ ИМЕНА}

DOI: $10.30901 / 2227-8834-2017-1-104-113$

Л. И. Орел,

Э. В. Трускинов

Федеральный

исследовательский центр

Всероссийский институт

генетических ресурсов

растений имени

Н. И. Вавилова,

190000 Санкт-Петербург,

ул. Б. Морская д. 42, 44,

Россия,

e-mail: truskinov@yandex.ru

Ключевые слова:

генетика, иитология

Поступление:

19.12.2016

Принято:

06.03.2017

\section{ГРИГОРИЙ АНДРЕЕВИЧ ЛЕВИТСКИЙ}

Григорий Андреевич Левитский - выдающийся ученый, классик цитогенетики, внесший большой вклад в изучение клеточных хромосом и кариосистематику культурных растений. Его имя значится в числе ближайших соратников Н. И. Вавилова, пригласившего Г. А. Левитского в 1925 г. в только что организованный Институт прикладной ботаники и новых культур (с 1930 г. Всесоюзный институт растениеводства - ВИР). Г. А. Левитский, отдавший работе в ВИР более 15 лет (1925-1941 гг.), организовал и возглавил Лабораторию цитологии.

\section{HISTORY OF AGROBIOLOGICAL RESEARCH AND VIR. NAMES OF RENOWN}

DOI: $10.30901 / 2227-8834-2017-1-104-113$

\section{I. Orel, E. V. Truskinov}

The N. I. Vavilov

All-Russian Institute of Plant Genetic Resources, 42, 44, Bolshaya Morskaya str., St. Petersburg, 190000 Russia, e-mail: truskinov@yandex.ru

Key words: genetics, cytology

Received:

19.12.2016

Accepted:

06.03.2017

\section{GRIGORY ANDREEVICH LEVITSKY}

Grigory Andreevich Levitsky is a classic of cytogenetics who made a great contribution to the study of cellular chromosomes and karyosystematics of cultivated plants. His name is listed among the closest associates of N. I. Vavilov who invited G. A. Levitsky in 1925 to the newly established Institute of Applied Botany and New Crops (in 1930 renamed the All-Union institute of Plant Industry, VIR). At this institute, Levitsky immediately organized and took leadership of the Laboratory of Plant Cytology and Anatomy. His fruitful work in this field was in 1933 interrupted by his arrest on trumped-up political charges. His arrest and exile in the same year was cancelled at N. I. Vavilov's request. Back at VIR, he continues with even greater intensity to work, combining experimental studies with active scientific and pedagogical work. A circle of talented employees and students formed around him, who subsequently became famous scientists, specialists- cytogeneticists. Large scientific generalization was his article "Cytological method in breeding" of the major collective work "Theoretical bases of plant breeding" issued by VIR in 1935. His outstanding scientific and pedagogical activity was finally interrupted in 1941, a year after the arrest of N. I. Vavilov. He was arrested on June 28, 1941, shortly after the war began. During the inquest he wrote a long report on his work and led the invesigators to his lab which completely rejected the charges against him in sabotage activities. G. A. Levitsky did not live till the court hearing and died on May 20, 1942. 


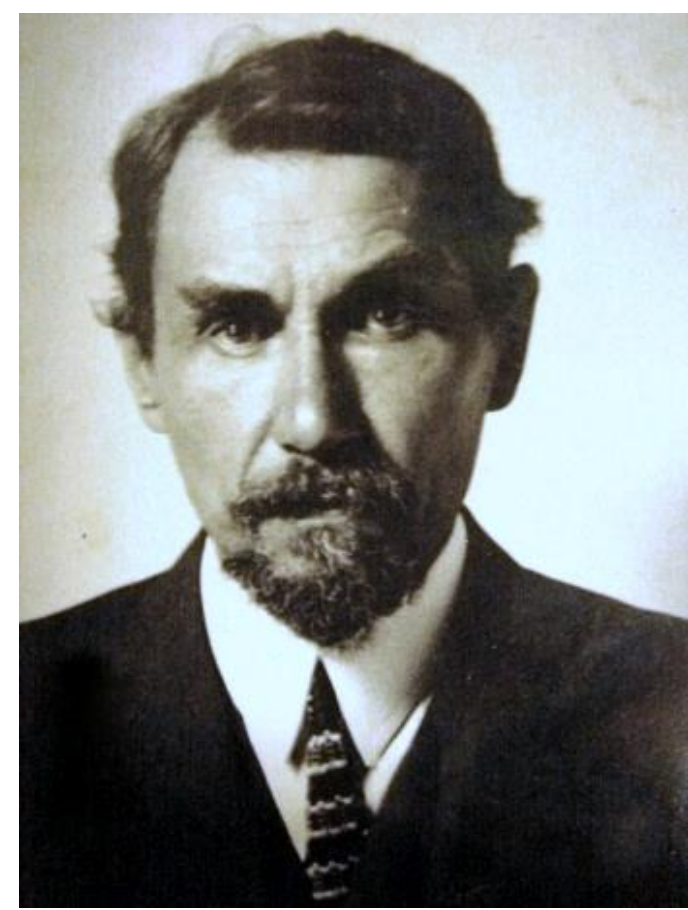

Григорий АнАреевич Аевитский 1878-1942 г.г.

Среди наиболее выдающихся соратников Николая Ивановича Вавилова, привлеченных им для работы во Всесоюзном институте растениеводства (тогда еще Институт прикладной ботаники и новых культур), безусловно, одно из первых, если не самое первое и почетное место, занимает Григорий Андреевич Левитский.

С именами Н. И. Вавилова и Г. А. Левитского связана вся история развития цитологических и эмбриологических исследований в ВИР. При взаимодействии двух замечательных, объединенных одной целью ученых, возникло, развилось и получило мировую известность фундаментальное научное направление, объединяющее цитологию, цитогенетику и эволюционную теорию.

Григорий Андреевич Левитский родился 7 (19) ноября 1878 г. в селе Белки Сквирского уезда Киевской губернии в семье священника. После окончания начальной школы он был принят в Киеве в Коллегию Павла Галагана - престижное и элитарное учебное заведение.

В 1897 г. Г. А. Левитский поступил на естественное отделение физико- математического факультета Киевского университета, избрав ботанику своей специализацией. После окончания университета в 1902 г. он начал работать лаборантом Ботанического кабинета Киевского политехнического института. В 1907 г. он был арестован за участие во Всероссийском съезде Крестьянского союза в Москве, заключен в Бутырскую тюрьму, где провел 8 месяцев и в качестве административного наказания был выслан из России на три года. Судьбе было угодно распорядиться таким образом, что годы, проведенные в Европе, стали для него годами внутренней работы и годами профессионального роста. Он изучал иностранные языки, проводил время на букинистических книжных развалах. В течение первого года он работает в музеях и библиотеках Парижа и Лондона; весь следующий год - на русской зоологической станции недалеко от Неаполя; с апреля 1909 г. по август 1910 г. - в ботаническом институте Боннского университета в качестве специалиста по цитологии. Здесь, работая под руководством известного цитолога Э. Страсбургера, он, фактически первым, на растительных клетках начал исследование митохондрий.

После возвращения в Россию в 1911 г. Григорий Андреевич продолжил начатые в Германии исследования и возобновил преподавательскую деятельность в Политехническом институте в Киеве. В 1914 г. он был мобилизован в армию, откуда вернулся через год в чине прапорщика. Успешно сдав магистерские экзамены в Киевском университете, с 1917 г. Г. А. Левитский стал там читать специальный курс «Строение и организация протоплазмы». В 1921 г. он был избран профессором кафедры морфологии и систематики растений Киевского сельскохозяйственного института, где преподавал до конца 1922 г., принимая также живейшее участие в создании Высших сортоводно-семенных курсов при Ученом сельскохозяйственном комитете и «Сахаротресте», читая там курсы общей биологии и биометрии. В эти же годы Г. А. Левитским была высказана блестящая гипотеза об изменчивости хромосом в связи с эволюционным процессом, а также написаны два учебника «Элементы биометрики. Статистический анализ изменчивости» (Levitsky, 
1922) и «Материальные основы наследственности» (Levitsky, 1924). Последняя книга имела особое значение. Наряду с учебниками Ю. А. Филипченко она стала настольным учебным пособием для студентов и преподавателей высшей школы. При работе именно над этой книгой сложились дружеские и творческие взаимоотношения c Н. И Вавиловым (Lebedev, Abramova, 1994). Кроме того, большой интерес у Николая Ивановича вызвало активное участие Г. А. Левитского в организации Киевского научного института селекции при «Сахаротресте», впоследствии преобразованном во Всесоюзный институт сахарной свеклы. В нем была создана лаборатория морфологии и систематики, которую он возглавил с 1922 г. Здесь работала Наталья Андреевна Кузьмина, жена и верная спутница Григория Андреевича. Ими была сделана и опубликована совместная работа «К вопросу о причинах наследственных различий в величине клеток по наблюдению за свеклой» (Levitsky, Kusmina, 1923), где было показано, что одни и те же наследственные факторы контролируют накопление сахара и задерживают рост. Этим объясняется повышенная сахаристость мелкоклеточных сортов свеклы.

В том же столь продуктивном для Г. А. Левитского 1922 г. Н. И. Вавилов приглашает его в Петроград для ознакомления с научной литературой, полученной библиотекой института. В начале 1923 г. он провел там еще несколько недель, что привело к созданию книги «Материальные основы наследственности» (Levitsky, 1924). Посылая книгу Николаю Ивановичу, автор пишет, что эти его поездки останутся навсегда в ряду лучших воспоминаний, так как с ними связано его возрождение в научной жизни и значительное расширение области интересов и исследования.

В 1925 г. Н. И. Вавилов официально предлагает Г. А. Левитскому перебраться в Ленинград и занять в институте должность заведующего Лабораторией цитологии и анатомии. Тот с благодарностью соглашается, но предупреждает Вавилова, что необходимо будет «произвести одну небольшую формальность». Дело в том, что необходимо было уже тогда удостоверить в органах ГПУ его политическую благона- дежность как бывшего эсера и «прапорщика запаса». Пришлось обратиться с ходатайством также к управделами СНК СССР Н. П. Горбунову, курировавшему институт. Разрешение было получено, и Г. А. Левитский приступил к работе в новой должности.

Переезд Г. А. Левитского в Ленинград в 1925 г. и начало деятельности цитологической лаборатории, которую он возглавил, знаменовали собой воплощение замыслов Н. И. Вавилова о комплексном исследовании мировых растительных ресурсов с помощью самых современных, в том числе цитологических методов. Многочисленные письма Н. И. Вавилова тех лет свидетельствуют о тех надеждах, которые он возлагал на цитологию, видя ее перспективность в осуществлении своих замыслов по изучению всего разнообразия растений с целью использованию этих знаний в селекции.

Ко времени переезда в Ленинград Г. А. Левитский был уже вполне сложившимся ученым, специалистом, широко эрудированным в вопросах как цитологии, так и генетики. Деловое предложение Н. И. Вавилова заняться изучением хромосом в Ленинграде совпало с научными интересами самого Г. А. Левитского. Особое значение Г. А. Левитский придавал роли эксперимента в цитологии, выяснению природы изменений, условий, вызывающих эти изменения и характер проявления изменений в ходе гибридизации, а также под воздействием изменений температуры внешней среды и радиации.

С 1925 г. Лаборатория цитологии располагалась на втором этаже дома номер 15 по Павловскому шоссе (дом сохранился до настоящего времени). В соседнем доме (этот дом не сохранился) поселилась семья Григория Андреевича - его жена и коллега по работе Н. Е. Кузьмина, и дети - Надежда и Иван. Несколько позже Лаборатория была переведена в бывший особняк великого князя Бориса Владимировича. Кабинет Г. А. Левитского был в помещении слева от крыльца на первом этаже. Для Григория Андреевича это был наиболее благоприятный для занятий наукой период жизни. Большой штат сотрудников, которых он сам подобрал, благоприятный климат в коллективе, созданный Н. И. Вавиловым, 
позволили начать широкомасштабную работу по хромосомам. По прошествии времени становится очевидным тот колоссальный эмоциональный заряд и стимул к научной работе, который получили молодые сотрудники в атмосфере взаимодействия с двумя корифеями, каковыми были Н. И. Вавилов и Г. А. Левитский. Хорошо известны в кругах специалистов работы сотрудников лаборатории: Н. П. Авдулова, Н. Т. Кахидзе, В. А. Поддубной-Арнольди, Н. В. Сеняниновой-Корчагиной, А. А. Прокофьевой-Бельговской, В. А. Рыбина и других (Orel, 2012; Truskinov, 2012).

Научно-исследовательской деятельность Лаборатории кроме фундаментального продвижения хромосомной теории, имела и прикладное значение, отраженное в работе «Цитологический метод в селекции» (Levitsky, 1935), включенной в первый том капитального труда ВИР - «Теоретические основы селекции». Именно эта книга дала в руки селекционеров новые, современные методы улучшения растений. Сейчас с гордостью можно констатировать, что Н. И. Вавилов и Г. А. Левитский были организаторами и руководителями одной из самых выдающихся школ цитологии своего времени, стояли у истоков цитогенетики. У Г. А. Левитского путь, от зарождения идеи к разработке методических и методологических подходов и оценке результатов эксперимента, к формулированию существенных для науки выводов, был связан сначала с разработкой методических вопросов, поисков способов фиксации материала и измерения длины плеч хромосом на препаратах.

В 1932 г. Г. А. Левитский был избран членом-корреспондентом Академии наук СССР. Именно в этот период наибольших научных достижений, по образному выражению известного ботаника Е. Н. Синской, «дракон выхватил» его из института. Г. А. Левитскому были предъявлены обвинения по связям с эсэрами в царское время и участие в несуществующей Трудовой крестьянской партии, дело которой фабриковалось органами НКВД в 30 -е годы. Н. И. Вавилов в одном из своих писем пишет, что выбыло из строя 20 человек, начиная с Г. А. Левитского, Н. А. Максимова, В. Е. Писарева. В автобиографии Григория Андреевича, написанной 3 марта 1941 г. и хранящей- ся в архиве ВИР, по поводу этих событий было сообщено, что в феврале 1933 г. он был арестован и административно выслан в Западную Сибирь. Об этом периоде его жизни пишет в своих воспоминаниях Е. Н. Синская (Sinskaya, 1991). Отрывок, который стоит привести, не был опубликован, но хранился в семье В. В. Суворова, который в то время работал в ВИР. Материал был любезно предоставлен его женой С. Д. Киселевой. «Его выслали в Сибирь в Красноярский край. За него усиленно хлопотали его жена и Н. И. Вавилов. Григорий Андреевич проводил лето в Сибири и там не унывал. Он изучал местный быт, восхишался девственной природой, не расставался, как он говорил, с определителем, пока не определил все растения местной флоры - он вообще любил это занятие. Г. А. был восхищен своим освобождением. Он говорил, что кто не виноват, так в этом всегда, в коние концов, разберутся. При пересмотре дела он был освобожден в ноябре 1933 г. С 4 ноября снова вступил на прежнюю должность заведующего лабораторией цитологии ВИР».

Обвинение в участии в Трудовой крестьянской партии, очевидно, было снято. Об этом есть свидетельство самого Г. А. Левитского, опубликованное в воспоминаниях Е. Н. Синской (Sinskaya, 1991). Ему было объявлено, что его проверили и что теперь он может жить спокойно, что ничего плохого с ним больше не случится, что он никогда больше не будет арестован. После того как Григорию Андреевичу удалось вернуться в ВИР, работа в Лаборатории вновь закипела. На стажировку из разных городов приезжали цитологи и селекционеры (Orel, 2012). В это же время Г. А. Левитский, по приглашению Н. И. Вавилова, стал работать в Лаборатории генетики Академии Наук (вплоть до переезда этой лаборатории в Москву в 1932 г.). Работая в Ленинграде, Г. А. Левитский продолжил свою педагогическую деятельность. В 1930-1932 гг. он был профессором кафедры морфологии и систематики растений в Молочноогородном институте (так в то время был переименован Агрономический институт). В 1934 г. Г. Д. Карпеченко пригласил его на должность профессора кафедры генетики растений Ленинградского государственного 
университета (ЛГУ) читать курс по цитологии растений. С 1938 по 1941 гг. Г. А. Левитский был профессором кафедры селекции, генетики и семеноводства Пушкинского сельскохозяйственного института. Следует сказать, что возвращение Г. А. Левитского из ссылки совпало с началом «лысенковской» и «презентовской» атаки на научные принципы деятельности института и обвинениями в адрес сотрудников, что порой сопровождалось крутыми административными мерами. Внутренняя жизнь института становилась все тяжелее. Как реагировал на это Н. И. Вавилов, видно из одного его высказывания, приведенного в воспоминаниях Е. Н. Синской (Sinskaya, 1991): «Наши фокусники не принимают во внимание весь долголетний опыт мировой науки, не хотят знакомиться с мнением других исследователей, они хотят жить в чем мать родила. И гений не в состоянии разобраться в сложных вопросах, если он невежда».

Когда нам в настоящее время попадают в руки книги, отражающие содержание научных дискуссий того времени, нелепость и абсурдность предъявляемых ученым обвинений просто поражают. Эта нелепость была бы смешной, если бы нам не было известно, как страшно все закончилось для многих ученых. Им инкриминировали антидарвинизм, отход от марксистского метода и материалистической диалектики и даже знание иностранных языков ставилось им в упрек. И. И. Презент на сессии ВАСХНИЛ в 1936 г., критикуя Н. И. Вавилова за якобы отход от дарвинизма, противопоставил ему «широкие массы колхозников, работающих над освоением дарвинизма». Эта, бессмыслица, по сути дела, послужила потом одним из оснований для предъявления политических обвинений в контрреволюционной деятельности. Атмосфера в обществе была такова, что Н. И. Вавилов, предвидя возможность арестов, советовал некоторым сотрудникам увольняться и уезжать.

С закатом яркой звезды Н. И. Вавилова, восходит мрачная, поначалу шальная, а затем вполне закономерная, в духе породившего ее политического режима звезда $\mathrm{T}$. Д. Лысенко. В 1934 г. его приглашают для научных консультаций в Детское Село. То, что он там побывал, свидетельствует фотография тех лет, где он изображен на полевом опытном участке ВИР в плотном окружении сотрудников станции. Н. И. Вавилов виден где-то с краю. Какие он давал консультации, не известно, но то, что здесь, в исконно вавиловском центре науки, появились его сторонники вполне достоверно.

Это не могло не сказаться на психологическом и рабочем климате в институте, и, конечно, самой станции, что явствует даже из тех официальных характеристик, которые давались сотрудникам. В отношении Г. А. Левитского была дана такая справкадонос: «Крайне самолюбив, резок в выступлениях, часто переходящих в антисоветские. Например, по докладу Презента в частном разговоре с т. Сизовым дал оценку: диалектическая трескотня, а не методология. Для подготовки кадров не стремится подобрать советскую молодежь, а подбирает «подходящих», т. е. из бывших людей. В общественно-политической работе участие сейчас принимает крайне слабое».

И. И. Презент, как известно, был ближайшим помощником и «идеологом» $\mathrm{T}$. Д. Лысенко. Ему принадлежит крылатое выражение «Вавилон должен быть разрушен», под Вавилоном подразумевался ВИР. Положение института с 1938 г., с тех пор, как президентом ВАСХНИЛ стал Лысенко, резко ухудшается: перестают выходить сборники трудов ВИР, сильно сокращается финансирование центра (особенно Пушкинская часть ВИРа) и его станций. Волевым указом Лысенко из Ученого Совета ВИР выводится ряд ведущих специалистов, в том числе Г. А. Левитский.

Именно тогда Н. И. Вавиловым было сказано: «Пойдем на костер, будем гореть, но от убеждений своих не откажемся!». Борьба с Лысенко и лысенковщиной (с их позицией неприятия законов классической генетики, буржуазной, по мнению лысенковцев, со скороспелыми методами и авантюрными обещаниями народного академика и его сторонников, спекулятивно позиционировавших себя как представителей мичуринской советской биологии) завершилась арестом Н. И. Вавилова 6 августа 1940 г. во время его экспедиции в только что присоединенную Западную Украину. Г. А. Левитский был арестован 28 июня 1941 
г. прямо в своей лаборатории в великокняжеском особняке, на крыльце которого его дети и видели отца в последний раз именно во время ареста. При подходе немцев семья не смогла эвакуироваться и попала в оккупацию. Позже жена Г. А. Левитского и его дети пережили все ужасы сталинских лагерей и узнали о судьбе своего отца только в 1956 г. В 1991 г. дочь Григория Андреевича смогла ознакомиться с материалами уголовного дела отца. Некоторые (Levitskaya, 1978; Levitskaya, Lassan, 1992; Orel, Truskinov, Levitskaya, 2014), сделанные ею выписки из этих документов стоит привести как отражающие вопросы, непосредственно связанные с работой, руководимой им Лаборатории: «По существу предъявленных мне вопросов могу показать следующее. $B$ коние 1925 года я был приглашен директором Всесоюзного Института Прикладной ботаники Н.И. Вавиловым на должность заведуютего Лабораторией Цитологии и Анатомии этого Института. Примерно через 2-3 года Анатомия культурных растений была выделена в особую Лабораторию с заведуюшим ею профессором $B$. A. Александровым, а мне осталась одна лаборатория Цитологии, каковое разделение сохранилось до последнего времени и в выросшем из Института Прикладной Ботаники Всесоюзном Институте Растениеводства. Из аналитических работ первого короткого иитолого-анатомического периода Лаборатории я отмечу работь по анатомии льна /Мельникова и Яковлева/. Одна из этих работ имела своим предметом анатомическую характеристику главнейших сортов этого растения для выяснения связи анатомического строения их стебля с технически иенными качествами их волокна - с иелью применения затем анатомического метода для сравнительной хозяйственной оценки селекционного материала льна непосредственно по самому растению - не дожидаясь получения из него волокна, что значительно облегчало и ускоряло прочесс оченки и делало возможным применение ее на массовом материале. Вторая работа имела ту же задачу хозяйственной оченки анатомического материала, но в отнотении различных условий культуры - в особенности густоты посева. Кроме этих, полностью проведенных у ме- ня работ, производились еще работы по сортовой анатомии ячменя, законченные далее уже в специальной Лаборатории Анатомии.

Лаборатория Цитологии имела своей задачей изучение последнего элемента построения культурного растения - клетки в связи с запросами растениеводства. Запросы эти слагаются из четырех основных задач, являюшихся отчасти и этапами растениеводческого проиесса. Первая из них состоит в изучении исходного материала культурного растения с точки зрения его внешних /морфологических/ особенностей с иелью установления видовых, разновидностных и сортовых отличий, позволяющих затем разобраться в разнообразии материала и его наследственно постоянных расах и дать им правильную, естественную классификаиию. Вторая задача это выделение из указанного материала наиболее иенных рас /m. называемая аналитическая селекция/. Третья задача синтетическая селекиия - это совмешение наиболее иенных особенностей, распределенных между разными расами, в одном сорте - при помощи скрещивания. И, наконеи, четвертая возможная задача - это непосредственная переделка наследственной природы растений.

В отнотении первой из этих задач ииитологический метод дает возможность как это было полностью применено в намей Лаборатории - более тонкого и существенного различения, чем обычный внешне-морфологический. Особенные услуги нами были оказаны в этом отношении в применении к пшеницам - как это могут засвидетельствовать знатоки этого растения проф. Фляксбергер и академик Н. И. Вавилов. Здесь во многих случаях решающими явились именно ичитологические особенности - для установления принадлежности данного образиа к одной из основных групп пшениц: однозернянок, твердых и мягких. Эти цитологические особенности столь важного значения - представлены в виде так называемых хромозом - особых тел, формируюшихся в клеточном ядре и своим числом и строением наиболее точно и тонко характеризуюших растение. Происходит это потому, что именно с этими телами связана главным образом матери- 
альная основа наследственных особенностей и признаков организма, как это исчерпьваюшим образом доказывается строго фактически в современной генетике. Вот почему именно изучению хромозом культурных растений и посвящена в основном масса работ Лаборатории Цитологии ВИРа. Особенности хромозом - их числа и строения - являются не только решающи ми в установлении систематической близости отдельных рас культурного растения - в иелях их естественной классификацчии, но и для всех следующих этапов селекции - аналитического и синтетического. Для первого особенно важным являются расы с кратно-умноженным числом хромозом; для второго - отличия в числе или строении хромозом представляют существенные препятствия для скрещиивания и придают особый специфический характер разнообразию потомства гибридов. Бесплодная трата труда и средств иногда бывает связана с попытками скрещивать без предварительного - цитологического исследования. Исходя из только что изложенного, первой задачей, поставленной перед Лабораторией Цитологии ВИРа, была поэтому ичитологическая характеристика культурных растений именно в отношении числа и строения хромозом.

Если в отношении числа их это было сравнительно легким делом и осуществленным для многих культурных растений, то различия в отношении их строения были к началу работь Лаборатории вовсе неизвестны, так как хромозомь культурных растений представлялись тогда в виде вообще однородных, не имеющих строения тел. Первой задачей Лаборатории - в отношении ичитологической характеристики - и стала поэтому разработка методов, вскрывающих, и точно характеризующих именно строение или морфологию хромозом. Эти методы были мною выработаны и описаны в особой монографии /193I/, а также применены к ряду культурных растений: рожь, ячмень, горох, бобы - а затем далее - как мною, так и моими сотрудниками - к подавляющему большинству культурных растений - начиная от пшениц и овсов и кончая чайным деревом, клещевиной, хлопчатником, маком и другими менее важными культурами. Для исчер- пывающей полноты в этом отношения были выполнены большие работы для целых семейств особенно богатых культурными растениями - как напр., объемистая монография по ичитологии злаков /400 с лишним страниц/, а также работы по ичитологии бобовых и зонтичных. В последуюшие годы работа в направлении дальнейшего усовершенствования методики все время продолжалась и повела к вскрытию последних элементов построения хромозом в виде так называемых хромомеров - как это было показано детально на примере ржи, а также на пшенице. Рядом и параллельно с основной работой по выработке новых методов исследования уже с самых первых лет были предприняты работы конкретного ичитологического исследования хотя бы и со стороны методики - как отдельных культурных растений, особенно указанных выле семейств, так и конкретных проблем, относящчихся к третьему этапу селекции - скрещчиванию или гибридизации, при этом с одной стороньл форм, различающихся числом хромозом, а с другой $u x$ строением. Из первых были исследованы межвидовые гибриды пшениц и затем гибриды от отдаленного скрещиивания между пшеницей и рожью. В последнем случае изентральной задачей стало выяснение причин появления среди этих обычно бесплодных гибридов отдельных растений /второго поколения/ с полной плодовитостью и наследственным постоянством растений промежуточных между рожью и пшеницей, соединяюших в известной мере их хозяйственные преимущества, а по своим признакам представляюших новый вид и род культурного растения, названного тритикале. Причины указанных, хозяйственно иенных свойств /плодовитости и константности/ мною были выявлены как результат цитологического преобразования, происшедшего в гибриде в виде удвоения числа его хромозом, вследствие чего становится нормальным прочесс образования половых элементов растения, обычно резко нарушенный у гибридов. Имеющиеся всё же некоторые ненормальности в этом отномении и у нашего гибрида, у разных его рас, повидимому, больше или меньше выраженные, требовали дальнейшей селекциионной работы с этим интересным ги- 
бридом, которая, к сожалению, несмотря на мои указания у нас в Союзе не была выполнена по ряду непреодолимых препятствий и проводится сейчас в Швеции.

$B$ отночении значения различий в строении хромозом для скрещчивания - как метода селекции - мною была предпринята работа с открытыми у нас же в Лаборатории отличиями хромозом у разных рас мака. В результате такого различия выявился особый тип разнообразия в потомстве гибридов, в виде ограниченного количества наследственно постоянных рас, чрезвычайно уклоняюшихся иногда от исходных форм. Подобного рода наследственно постоянные "новообразования" могут иметь большое значение для создания новых форм культурных растений,

Четвертый этап растениеводства непосредственная переделка наследственной природы культурного растения - задача пока еще совершенно новая - отразился на работе нашей Лаборатории пока лишь в исследовании преобразований хромозом под влиянием рентгеновских лучей, ведущиих к формированию новых наследственно постоянных рас с измененными хромозомами. В области, связанной с другой составляющзей клетки - протоплазмой в Лаборатории ичитологии была возможна кандидатская работа по выяснению внутриклеточных причин яровизачии, каковые казались связанными с формированием под влиянием этого воздействия на проростки особого "внутреннего" хлорофилла - красящего зеленого вещества, типичного для растений» (Levitskaya, 1978; Levitskaya, Lassan, 1992; Orel, Truskinov, Levitskaya, 2014).

Далее Г. А. Левицкий переходит непосредственно к тем конкретным обвинениям, которые ему были предъявлены. Он полностью отвергает свою причастность к Трудовой крестьянской партии, ссылаясь на то, что был уже приговорен по этому делу к трехлетней административной высылке в Западную Сибирь, а через семь месяцев после прибытия на место высылки был полностью реабилитирован Верховной Прокуратурой Союза, вернулся в Ленинград и был принят на прежнее место в ВИР. Относительно обвинения о существовании в ВИР антисоветской организации вредительского характера, в которой он якобы участвовал, основанное на показаниях арестованного академика ВАСХНИЛ Бондаренко со ссылкой на свидетельство Н. И. Вавилова, он требует очной ставки всех троих, т. к. уверен, что Вавилов или вовсе ничего подобного не говорил Бондаренко, или - нечто совсем другое, им затем совершенно извращенное и без этого показание Бондаренко не имеет никакой доказательной цены (Бондаренко к тому времени был расстрелян, а Н.И. Вавилов томился в саратовской тюрьме). Относительно обвинений, исходящих от Бондаренко и порочащих работу Лаборатории цитологии ВИР, Г. А. Левитский аргументировано их отвергает, убедительно уличая того в полной неосведомленности в том предмете, о котором он пишет: «Таковы обвинения, предъявленные мне во втором допросе следователя в 2. Златоусте и имеюшие более конкретный характер. Их бездоказательность для меня очевидна. Остаются обвинения общего характера в «теоретичности», «академичности», «оторванности от практики» и т. д. На это можно сказать, что установление связи цинтологии с растениеводством дело вообще новое, датирующееся в основном лишь с двадцатых годов текущуего столетия и почти совпавшее с началом работ Лаборатории Цитологии ВИРа. Естественно поэтому, что при этих условиях значительная часть работ Лаборатории была посвящена циитологическому ознакомлению с обширным материалом культурных растений, с выработкой методов исследования, а также выяснению некоторых основных вопросов принциниального, теоретического характера. Отказаться от такой, более широкой постановки исследований и сразу сосредоточиться лишь на очередных отдельных практических запросах едва ли было бы правильно для Центральной Лаборатории такого рода в Союзе и в конечном счете привело бы во многих отношениях к бесплодному топтанию на месте. Тем не менее, работая на углубленной теоретической базе, Лаборатория Цитологии ВИР как в построении плана своих работ, так и в своих конкретных темах никогда не упускала из виду своей связи с основнылм запросами практического растениеводства, которое она была призвана обслуживать. 
Я думаю, что связь эта достаточно ясно показана в изложении работы Лаборатории и что она сделала в этом отномении максимум того, что вообще можно было сделать».

После изучения этого документа следователь в Ленинграде решает приостановить дело до окончания войны из-за невозможности экспертизы в условиях военного времени. Однако после отправки заключенного в Златоуст, там сочли, что обвиняемый достаточно изобличен, и приняли дело к производству. До суда Г. А. Левитский не дожил, он скончался 20 мая 1942 г. Ненамного дольше пережил его в саратовской тюрьме и Н. И. Вавилов.

В посмертной судьбе Г. А. Левитского было еще одно событие, достойное упоминания. 14 июня 1945 г., в связи с празднованием 200-летия Академии наук СССР, был опубликован Указ Президиума Верховного Совета СССР о награждении ряда ее членов. Среди награжденных орденом Трудового Красного Знамени значился член-корреспондент Г. А. Левитский. Объяснением этого казуса могла быть лишь бюрократическая неразбериха в органах НКВД и двух разных академических ведомств, особенно в условиях военного времени. Лишь 17 декабря 1955 г. прокуратурой Ленинграда дело в отношении Г. А.
Левитского было прекращено «за недостаточностью улик», и только 28 марта 1989 г. эта формулировка была заменена на «отсутствие состава преступления».

Посмертная судьба научного наследия Г. А. Левитского, памяти о нем, к счастью сложилась достойно его имени и заслуг. Были опубликованы его избранные труды в двух томах. В 1978 г. (в его столетний юбилей) в ВИР был издан посвященный ему сборник, приведена библиография его работ (Levitskaya, 1978). В Розовом зале института установлен замечательный скульптурный портрет Григория Андреевича Левитского, честь, которой удостоен только основатель ВИР - Н. И. Вавилов. В 2012 году - год 90-летия Пушкинских лабораторий ВИР, рядом с великокняжеским коттеджем, где находилась Лаборатория цитологии, был установлен мемориальный камень с именами Н. И. Вавилова и наиболее выдающихся ученых здесь работавших. Имя Г. А. Левитского стоит в списке среди первых после Н. И. Вавилова. Он действительно был ближайшим его соратником, ученым, чьи труды по праву вошли в золотой фонд отечественной и мировой науки. ВИР должен гордиться и помнить, что в его стенах работал, творил этот выдающийся цитолог и замечательный во всех отношениях человек.

\section{Referances/Литература}

Lebedev D. V., Abramova L. I. Grigory Andreevich Levitsky // In: Nicolai Ivanovich Vavilov's Associates. Researchers of plant genetic diversity. St. Petersburg: VIR, 1994, pp. 303-322 [in Russian] (Лебедев Д. В., Абрамова Л. И. Григорий Андреевич Левитский // В кн.: Соратники Николая Ивановича Вавилова. Исследователи генофонда растений. СПб.: ВИР, 1994. C. 303-322).

Levitskaya N. G. Bibliography of G. A Levitsky // Bulletin of N. I. Vavilov's VNIIR, 1978, iss. 83, pp. 15-21 [in Russian] (Левитская Н. Г. Библиография работ Г. А. Левитского // Бюлл. ВНИИР им. Н. И. Вавилова. 1978. Вып. 83. C. 15-21).

Levitskaya N. G., Lassan T. K. Grigory Andreevich Levitsky: Materials for the biography // Cytology, 1992, no. 8, pp. 102-125 [in Russian] (Лeвитская Н. Г., Лассан Т. К. Григорий Андре- евич Левитский: Материалы к биографии // Цитология. 1992. №8. С. 102-125).

Levitsky G. A. Cytological method in breeding // In: The theoretical basis of selection. Vol. 1. Leningrad: State publishing house, 1935, pp. 493524. [in Russian] (Левитский Г. А. Цитологический метод в селекции // Теоретические основы селекции. Т. 1. Л.: Госиздат, 1935. С. 493-524).

Levitsky G. A. Elements of biometrics. Public a guide for naturaliss and agronomists. Part I. Statistical analysis of the phenomena of variability. Kiev: Sugartrust, 1922, 118 p. [in Russian] (Лeвитский $Г$. А. Элементы биометрики. Общедоступное руководство для натуралистов и агрономов. Часть 1. Статистический анализ явлений изменчивости. Киев: Сахаротрест, 1922. 118 c.).

Levitsky G. A. Material basis of heredity. Kiev: The state publishing house of Ukraine, 1924, $166 \mathrm{p}$. 
[in Russian] (Левитский Г. А. Материальные основы наследственности. Киев. Госиздат Украины, 1924. 166 с.).

Levitsky G. A., Kusmina N. E. To the question about the causes of hereditary differences in the size of the cells according to the observation over the beets // Bulletin sort-seed management of Sugartrust. Kiev, 1923, no. 6, pp. 84-92 [in Russian] (Левитский Г. А., Кузьмина Н. Е. К вопросу о причинах наследственных отличий в величине клеток по наблюдениям над свеклой // Бюллетень Сортоводно-семенного управления Сахаротреста. Киев, 1923. № 6. C. 84-92).

Orel L. I., Truskinov E. V., Levitskaya N. G. Grigory Andreevich Levitsky. People of science. St. Petersburg: VIR, 2014, 30 p. [in Russian] (Орел Л. И., Трускинов Э. В., Левитская Н. Г. Григорий Андреевич Левитский. Люди науки. СПб.: ВИР, 2014. 30 с.).
Orel. L. I. Cytological and embryological studies. Pushkin laboratory of VIR (1922-2012). A collection of articles and memories. St. Petersburg, Pushkin, 2012, pp. 40-57 [in Russian] (Орел Л. И. Цитологические и эмбриологические исследования. Пушкинские лаборатории ВИР (1922-2012). Сборник статей и воспоминаний. Санкт-Петербург, Пушкин, 2012. С. 4057).

Sinskaya E. N. Memories of N. I. Vavilov. Kiev: «Naukova Dumka», 1991, 205 p. [in Russian] (Синская Е. Н. Воспоминания о Н.И. Вавилове. Киев: «Наукова думка», 1991. 205 с).

Truskinov E. V. History of the Pushkin laboratories of the VIR. Pushkin laboratory of VIR (19222012). A collection of articles and memories. St. Petersburg, Pushkin, 2012, pp. 4-14 [in Russian] (Трускинов Э. В. История Пушкинских лабораторий ВИР. Пушкинские лаборатории ВИР (1922-2012). Сборник статей и воспоминаний. СПб., Пушкин, 2012. С. 4-14). 
УДК 633.2: 631.524.85: 632.122.1: $581.1 .051(069.5)$

Н. И. Дзюбенко, А. В. Бухтеева, А. А. Кочегина. Многолетние и однолетние засухо- и солеустойчивые кормовые растения в Вавиловской коллекции. Тр. по прикл. бот., ген. и селек. Т. 178. Вып. 1. СПб., 2017. С. 5-23. Библ. 44.

Представлена 100-летняя история создания коллекции мировых генетических ресурсов засухо- и солеустойчивых многолетних и однолетних кормовых растений ВИР (Всероссийский институт генетических ресурсов растений имени Н. И. Вавилова). Проведены многочисленные экспедиции по сбору ценного исходного материала, созданы и изучены на станциях ВИР коллекции ряда засухоустойчивых кормовых растений. Селекционеры ВИР, его опытной сети и других селекционных учреждений вывели на основе Вавиловской коллекции ценные засухоустойчивые сорта. Теоретические и практические исследования по физиологии пустынных растений в ВИР получили дальнейшее развитие. В настоящее время для оценки солеустойчивости применяются молекулярные методы.

Ключевые слова: коллекция кормовых трав ВИР, засухоустойчивость, солетолерантность, люцерна, молекулярные маркеры

N. I. Dzyubenko, A. V. Bukhteeva, A. A. Kochegina. Perennial and annual drought- and salt-resistant Forage plants in the Vavilov collection. Proceedings on applied botany, genetics and breeding. Vol. 178. Iss. 1. SPb.: VIR, 2017. P. 6-23. Bibl. 44.

The 100-year history of building up the VIR collection of genetic resources of drought- and salt-resistant perennial and annual forage crops and its current status are described. Numerous expeditions were conducted to collect valuable germplasm material. The collections of a number of drought- and salt-resistant forage plants were established and studied. Breeders from VIR, its network and other breeding centers developed drought-resistant and salt-resistance varieties on the basis of the Vavilov collection. Theoretical and practical research on the physiology of desert plants was further developed. Currently salt tolerance of forage crops is assessed using molecular methods.

Key words: VIR collection of forage plants, drought-resistant forage plants, drought and salt resistance, alfalfa, molecular markers.

УДК 634.7:581.1 (470.621)

Е. А. Добренков, Л. Г. Семенова, С. Е. Дунаева, Ю. В. Ухатова. Адаптация пробирочных растений ежевики к полевым условиям среды. Тр. по прикл. бот., ген. и селек. Т. 178. Вып. 1. СПб., 2017. С. $24-30$. Библ. 10.

Изучена жизнеспособность образцов ежевики в естественных условиях среды после их хранения в культуре in vitro. В полевых условиях (2009-2015 гг.) изучены фенологические фазы развития взрослых растений, их урожайность и водный режим. Дана оценка адаптивности образцов к неблагоприятным факторам среды (зимо- и жаростойкость, засухоустойчивость, устойчивость к микозам).

Ключевые слова: ежевика, пробирочная культура, полевые условия, адаптивность

E. A. Dobrenkov, L. G. Semenova, S. E. Dunaeva, Y. V. Ukhatova. Adaptation of in vitro blackberry plants to field environments. Proceedings on applied botany, genetics and breeding. Vol. 178. Iss. 1. SPb.: VIR, 2017. P. 2530. Bibl. 10.

Viability of blackberry accessions in vivo after in vitro culture storage was analyzed. Phenological development phases of adult plants, crop yield and water regime were studied in the field. Adaptability of the accessions to adverse environmental factors (frost, drought and heat resistance, resistance to fungal infections) was evaluated.

Key words: blackberry, in vitro, field conditions, adaptability

УДК 633.14:631.527:581.19

В. Д. Кобылянский, О. В. Солодухина, И. В. Лунегова, С. П. Новикова,

М. С. Хлопюк 4 , В. И. Макаров. Создание низкопентозановой ржи и возможности ее использования на корм животным. Тр. по прикл. бот., ген. и селек. Т. 178. Вып. 1. СПб., 2017. С. 31-40. Библ. 17.

Представлен краткий обзор результатов наших исследований по разработке технологии селекции низкопентозановой озимой ржи и созданию первых сортов, пригодных для использования в комбикормовой промышленности. Проведены исследования по изучению кормовой ценности зерна новой ржи на лабораторных и сельскохозяйственных животных. Показана возможность успешного использования зерна низкопентозановой ржи при кормлении поросят и птицы.

Ключевые слова: зернофуражная рожь, генетика, технология селекции, сорт, рационы, крысы, свиньи, цыплята.

V. D. Kobyliansky，O. V. Solodukhina，I. V. Lunegova，S. P. Novikova，M. S. Hlopyuk, V. I. Makarov. Rye breeding for low-pentosans and possibility of its use in animal feeding. Proceedings on applied botany, genetics and breeding. Vol. 178. Iss. 1. SPb.: VIR, 2017. P. 32-40. Bibl. 17.

The strategy and technology of rye breeding for low water-soluble arabinoxilans (WS-AX) in grain were proposed. Together with breeders from other institutions we developed the first six low-pentosan varieties of winter rye suitable 
for grain forage use. Seeds of low-pentosan forage rye do not form viscous mucus in animal stomachs, thus eliminating the problem that exists when feeding classic baking rye. When using them as fodder for laboratory and farming animals, high palatability and nutritional value were observed.

Key words: grain forage rye, genetics, technology of breeding, variety, diets, rats, pigs, chicken.

\section{УДК 633.13:631.527}

Т. Е. Кузнецова, С. А. Левштанов, Н. В. Серкин. Селекция овса на Кубани. Тр. по прикл. бот., ген. и селек. Т. 178. Вып. 1. СПб., 2017. С. 41-47. Библ. 7.

В статье представлена история селекции овса на Кубани. Созданы и переданы на государственное испытание два сорта ярового овса 'Десант' и 'Ассоль'. Дана полная характеристика новых сортов.

Ключевые слова: овес, коллекция, сорт, линия, отбор, открытое цветение, перекрестное опыление, рекомбиногенез, мутация.

T. E. Kuznetsova, S. A. Levshtanov, N. V. Serkin. Oat breeding in the Kuban region. Proceedings on applied botany, genetics and breeding. Vol. 178. Iss. 1. SPb.: VIR, 2017. P. 42-47. Bibl. 7.

The article presents the history of oat breeding in the Kuban region. Two varieties of spring oats 'Desant' and 'Assol' have been developed and submitted for the state trials. New varieties are described in detail.

Key words: oats, collection, variety, line, selection, open flowering, cross-pollination, recombination, mutation.

УДК 635.657-152(571.1)

С. П. Кузьмина, Н. Г. Казыдуб, Е. А. Черненко. Перспективы и результаты изучения коллекции нута в Омском ГАУ. Тр. по прикл. бот., ген. и селек. Т. 178. Вып. 1. СПб., 2017. С. 48-57. Библ. 14.

В Омском ГАУ в 2012-2016 гг. было изучено 23 образца нута коллекции ВИР и 23 образца нута коллекции сомаклонов Сибирского НИИ кормов. В результате научно-исследовательской работы в южной лесостепи Западной Сибири выделены образцы нута с укороченным вегетационным периодом, высокой продуктивностью растений, технологичностью, высокой симбиотической активностью. Показана возможность использования кластерного анализа для комплексной оценки исходного материала в селекции нута. Определен характер наследования хозяйственно ценных признаков у гибридов $\mathrm{F}_{1}$ нута, даны рекомендации для проведения отбора. Выявлена корреляция между основными признаками.

Ключевые слова: нут, образец, признак, элементы урожайности, кластерный анализ

S. P. Kuzmina, N. G. Kazydub, E. A. Chernenko. Prospects and results of studying the collection of chickpea from VIR at Omsk state Agrarian University. Proceedings on applied botany, genetics and breeding. Vol. 178. Iss. 1. SPb.: VIR, 2017. P. 49-57. Bibl. 14.

In 2012-1016, 23 chickpea accessions from VIR and 23 accessions from the collection of chickpea somaclones of the Siberian Research Institute of Forages were studied at Omsk State Agrarian University. The research performed in the southern forest-steppe of West Siberia resulted in identifying chickpea accessions with a shorter growing season, high plant productivity, good processability, and high symbiotic activity. The possibility of using cluster analysis for comprehensive assessment of source material for chickpea breeding was demonstrated. The nature of inheritance of agronomic traits in $\mathrm{F}_{1}$ chickpea hybrids was revealed, and recommendations for selection were formulated. A correlation was established between the major characters.

Key words: chickpea, accession, character, yield components, cluster analysis

\section{УДК 633.13}

Б. Лапински и А. Рачвалска. Использование Avena macrostachya для улучшения зимостойкости овса в Польше. Тр. по прикл. бот., ген. и селек. Т. 178. Вып. 1. СПб., 2017. С. 58-67. Библ. 19.

Польская программа по улучшению зимостойкости овса началась с 2002 г. Иностранные зимующие сорта и линии овса были скрещены с выделенными образцами тетраплоидного многолетнего дикого вида Avena macrostachya Bal. ex Coss et Dur. Гибриды $\mathrm{F}_{1}$ клонировали, обрабывали колхицином и, для спонтанного опыления, выращивали вместе с зимующими сортами овса. Были получены три гибрида, из которых два сформировали семена. Большие различия были замечены в уровне фертильности и структуре хромосом в потомстве двух гибридов. Следующее поколение $\left(\mathrm{B}_{1} \mathrm{~F}_{1}\right.$ или $\left.\mathrm{F}_{2}\right)$ состояло из растений с числом хромосом от 40 до 49 , октоплоидов $(2 \mathrm{n}=56)$ и растений, несущих в своем генотипе от 60 до 70 хромосом. Растения из первой группы мнимых гексаплоидов, как правило, обладали мужской стерильностью, но после дополнительного бекроссирования пыльцой A. sativa L. они становились фертильными. Показано, что октоплоиды не болеют, формируют большое количество зеленой массы и очень крупное зерно, богатое белком, однако их зерновая продуктивность не велика (в настоящее время она составляет только 50-67\% от урожайности лучших зимующих сортов овса) и вегетационный период удлинен. Последний суровый зимний сезон (2015/2016 гг.) был полезным для отбора нескольких новых гексаплоидных линий из комбинаций скрещиваний $6 \mathrm{x} \times 8 \mathrm{x}$, сделанные для трансгрессии морозоустойчивости от октоплоидного родителя. Аллоплоиды sativa-macrostachya с уровнем плоидности $8 \mathrm{x}$ или 10x оказались эффективными источниками зимостойкости для гексаплоидного овса. 
Ключевые слова: Аллоплоид, Avena macrostachya, Avena sativa, скрещивание, зимостойкость, зимующий овес, урожай

B. Lapinski, A. Rachwalska. Using Avena macrostachya for improvement of oat winterhardiness in Poland. Proceedings on applied botany, genetics and breeding. Vol. 178. Iss. 1. SPb.: VIR, 2017. P. 59-67. Bibl. 19.

The Polish program of winter oat breeding started in 2002 from interspecific crossing of foreign winter oats with the accessions of tetraploid perennial wild species Avena macrostachya Bal. ex Coss et Dur. Single hybrids were obtained in three cross combinations. Large differences were noticed in fertility level and chromosome constitution of progeny of the intensely cloned and colchicine treated $\mathrm{F}_{1}$ hybrids. The B1F or F2 generation consisted of plants with chromosome numbers between 40 and 49 , octoploids $(2 n=56)$ and plants carrying 60 to 70 chromosomes. The quasihexaploids of the first group were partly or completely sterile, but their chromosome complement was quickly regulated and fertility restored, usually after additional back-cross to A. sativa L. A few generations later they produced valuable breeding strains. In field experiments in Radzików (near Warsaw) and Grodkowice (near Krakow), they showed high yielding potential and no negative effects of wild germplasm. In the dry seasons 2009 and 2013 winter oats produced yields nearly $100 \%$ higher than the spring cultivar standard. Test weight of the winter oat was also ca. $4 \mathrm{~kg} / \mathrm{hl}$ higher than in the spring oat. Two of the husked strains, showing winterhardiness level better than the starting A. sativa population, are in the Polish state variety trials (from 2014 and 2015) 2015. They could be recommended for the regions with stable snow cover, because they were not able to survive naked ground surface temperatures below $-14 \mathrm{oC}$, which happened twice in Radzików and once in Grodkowice in the last 8 years of field trials. Especially the last winter (2015/2016) was destructive, even for the octoploids, which were earlier considered the most winter-hardy oats. The octoploids produce healthy green mass and very large plump grain, rich in protein, however they require a breeding effort to increase yield (now 50-67\% of the best winter hexaploids) and to make ripening uniform. The last severe winter season revealed several new hexaploid strains, transgressive in frost resistance to the octoploids. The $8 \mathrm{x}$ or 10x sativa-macrostachya alloploids proved to be effective sources of winterhardiness for hexaploid oat.

Key words: Alloploidy, Avena macrostachya, Avena sativa, wide cross, winterhardiness, winter oat, yield

УДК:633.521; 575.13; 575.11. 1, 3; 575.117

Е. А. Пороховинова.

Генетический контроль восстановления фертильности пыльцы у линий льна (Linum usitatissimum L.) с цитоплазматической мужской стерильностью. Тр. по прикл. бот., ген. и селек. Т. 178. Вып. 1. СПб., 2017. C. 68-81. Библ. 24.

В качестве источников ЦМС у льна использованы три линии: гк-204 с открытым цветком, укороченными изогнутыми тычиночными нитями, стерильными пыльниками, завязывает немного семян при самоопылении, гк-208 и гк-188 фертильны, стерильность проявляется только при гибридизации с другими линиями. Эти линии могут быть вовлечены в гетерозисную селекцию. Выявлены гены восстановления фертильности RFO8, RFO9. Рецессивные аллели генов восстановления фертильности $r f t 3-2, r f t 3-3, r f t 3-6, r f t 3-7, r f t 5-2, r f t 6, r f t 7$ и доминантная RFT4-3 определяют трубчатую форму стерильных цветков и нежелательны для селекции, так как снижают вероятность перекрестного опыления. Другие рецессивные (альтернативные) аллели генов восстановления фертильности пыльцы $r f o 6, r f o 6-2, r f o 6-3, r f o 7$ не влияют на форму венчика.

Ключевые слова: Linum usitatissimum, генетическая коллекция, гены $R f$, дискриминантный анализ, плейотропный эффект ЦМС, трубчатая форма цветка.

E. A. Porokhovinova. Genetic control of fertility restoration in CMS lines of flax (Linum usitatissimum). Proceedings on applied botany, genetics and breeding. Vol. 178. Iss. 1. SPb.: VIR, 2017. P. 69-81. Bibl. 24.

Three flax lines: gc-204 (with opened flowers, curved stamen filaments, sterile anthers, forming few seeds by selfpollination), gc-208 and gc-188 (fertile ones, sterility occurs only when hybridized with other lines) were used as CMS sources. These lines can be involved in heterosis breeding. Genes controlling male fertility restoration RFO8, $R F O 9$ were identified. Recessive alleles of the genes restoring fertility $r f t 3-2, r f t 3-3, r f t 3-6, r f t 3-7, r f t 5-2, r f t 6, r f t 7$ and dominant RFT4-3 determine tubular shape of sterile flowers, and are undesirable for breeding because the probability of cross pollination decreases. Other recessive (alternative) alleles of pollen fertility restoration genes $r f o 6$, rfo6-2, rfo6-3, rfo 7 do not affect the corolla's shape.

Key words. Linum usitatissimum, genetic collection, $R f$ genes, discriminant analysis, pleiotropic effect of CMS, tubular shape of the flower.

УДК 634.22: 581.4:631.526.3

У. И. Канцаева, В. М. Горина. Морфолого-биологические признаки крупноплодной алычи (Prunus × rossica Eremin) и их значение для проведения экспертизы сортов на отличимость, однородность и стабильность (ООС). Тр. по прикл. бот., ген. и селек. Т. 178. Вып. 1. СПб., 2017. С. 82-91. Библ. 10.

Приведены результаты многолетних исследований морфолого-биологических признаков шести сортов гибридной алычи (Prunus $\times$ rossica Eremin - Слива русская). Выявлено значение морфолого-биологических признаков при экспертизе сортов на отличимость, однородность и стабильность. Сорта 'Андромеда', 'Де- 
сертная Ранняя’, ‘Обильная’, ‘Оленька', ‘Румяная Зорька', ‘Фемида’ удовлетворяют критериям отличительности, однородности и стабильности, что подтверждено заключениями экспертов Госкомиссии по испытанию сортов.

Ключевые слова: алыча, гибридная алыча, Prunus cerasifera, Prunus $\times$ rossica, Rosaceae, сорт, морфологобиологические признаки, отличимость, однородность, стабильность.

U. I. Kantsayeva, V. M. Gorina. Morphological and biological traits of large-fruited cherry plum (Prunus $\times$ Rossica eremin) and their importance for expert examination of varieties for their distinctness, homogeneity and stability (DHS). Proceedings on applied botany, genetics and breeding. Vol. 178. Iss. 1. SPb.: VIR, 2017. P. 8391. Bibl. 10.

This work presents the results of long-term research on morphological and biological traits of six hybrid cherry plum varieties (Prunus $\times$ rossica Eremin). Such morpho-biological traits are shown to have significance during expert examination of varieties for distinctness, homogeneity and stability. The studied varieties ('Andromeda', 'Desertnaya Rannyaya', 'Obil'naya', 'Olen 'ka', 'Rumyanaya Zor'ka' and 'Femida') meet the criteria of distinctness, homogeneity and stability, which has been confirmed by the experts from the State Variety Testing Commission.

Key words: cherry plum, hybrid cherry plum, Prunus cerasifera, Prunus $\times$ rossica, Rosaceae, variety, morphological and biological traits, distinctness, homogeneity, stability.

\section{УДК 632.938.1}

В. А. Бирюкова, И. В. Шмыгля, С. Б. Абросимова, В. В. Мананков, А. В. Митюшкин, Е. В. Рогозина, С. Д. Киру, Н. А.Чалая, А. А. Мелешин, В. А. Жарова. Применение молекулярных маркеров в селекции на устойчивость к картофельной цистообразующей нематоде. Тр. по прикл. бот., ген. и селек. Т. 178. Вып. 1. СПб., 2017. С. 92-103. Библ. 17.

В статье представлены результаты применения молекулярных маркеров генов устойчивости к картофельной цистообразующей нематоде на разных этапах селекции картофеля - для скрининга генетических коллекций и перспективных гибридов Всероссийского научно-исследовательского института картофельного хозяйства $($ ВНИИКХ) и Всероссийского института генетических ресурсов растений (ВИР). Установлено, что «ложноположительные» и «ложноотрицательные» результаты маркер опосредованной селекции связаны не только со специфичностью используемых маркеров, но и с недостаточной объективностью фенотипической оценки на устойчивость к нематоде.

Ключевые слова: картофельная цистообразующая нематода, молекулярные маркеры, гены устойчивости, маркер опосредованная селекция (МОC)

V. A. Biryukova, I. V. Smiglya, S. B. Abrosimova, V. V. Manankov, A. V. Mityushkin, E. V. Rogozina, S. D. Kiru, N. A. Chalaya, A. A. Meleshin, V. A. Zharova. Application of molecular markers in breeding for resistance to potato cyst nematode. Proceedings on applied botany, genetics and breeding. Vol. 178. Iss. 1. SPb.: VIR, 2017. P. 93-103. Bibl. 17.

The article presents the results of the application of molecular markers of the genes controlling resistance to potato cyst nematode in different stages of potato breeding - for screening genetic collections and promising hybrids of the All-Russian Institute of Potato Research and the Vavilov Institute of Plant Genetic Resources. It has been established that "pseudopositive" and "pseudonegative" results of a marker-mediated breeding process are associated not only with the specificity of the used markers, but with a lack of objectivity in phenotypic evaluation for resistance to the nematode.

Key words: potato cyst nematode, molecular markers, resistance gene, marker-mediated breeding.

УДК 575.1

Л. И. Орел, Э. В. Трускинов. Григорий Андреевич Левитский. Тр. по прикл. бот., ген. и селек. Т. 178. Вып. 1. СПб., 2017. С. 104-113. Библ. 11.

Представлен биографический очерк выдающегося ученого - цитогенетика Г. А. Левитского, ближайшего соратника Н. И. Вавилова, отдавшего более 15 лет (1925-1941 гг.) работе в ВИР, организовавшего и возглавившего здесь Лабораторию цитологии. Отмечены его научные заслуги и трагизм судьбы, очень схожей с Вавиловской.

Ключевые слова: генетика, цитология

L. I. Orel, E. V. Truskinov. Grigory Andreevich Levitsky. Proceedings on applied botany, genetics and breeding. Vol. 177. Iss. 2. SPb.: VIR, 2017. P. 104-113. Bibl. 11.

This article is a biographical essay about a prominent scientist - the cytogeneticist G. A. Levitsky, N. I. Vavilov's closest associate, who devoted more than 15 years (1925-1941) to his work at VIR, who organized and headed the Laboratory of Cytology there. His scientific achievements and tragic fate, very similar to Vavilov's, are highlighted.

Key words: genetics, cytology. 


\section{СОДЕРЖАНИЕ}

\section{ИЗУЧЕНИЕ И ИСПОЛЬЗОВАНИЕ ГЕНЕТИЧЕСКИХ РЕСУРСОВ РАСТЕНИЙ}

Дзюбенко Н. И., Бухтеева А. В., Кочегина А. А. Многолетние и однолетние засухо- и солеустойчивые кормовые растения в Вавиловской коллекции.

Е. А. Добренков, Семенова Л. Г., Дунаева С. Е., Ухатова Ю. В. Адаптация пробирочных растений ежевики к полевым условиям среды.

\section{КОЛЛЕКЦИИ МИРОВЫХ ГЕНЕТИЧЕСКИХ РЕСУРСОВ КУЛЬТУРНЫХ РАСТЕНИЙ ДЛЯ РАЗВИТИЯ ПРИОРИТЕТНЫХ НАПРАВЛЕНИЙ СЕЛЕКЦИИ}

Кобылянский В. Д., Солодухина О. В., Лунегова И. В., Новикова С. П., Хлопюк М. С., Макаров В. И. Создание низкопентозановой ржи и возможности ее использования на корм животным.

Кузнецова Т. Е., Левштанов С. А., Серкин Н. В. Селекция овса на Кубани.

Кузьмина С. П., Казыдуб Н. Г., Черненко Е. А. Перспективы и результаты изучения коллекции нута в Омском ГАУ.

Лапински Б., Рачвалска А. Использование Avena macrostachya для улучшения зимостойкости овса в Польше.

ГЕНЕТИКА КУЛЬТУРНЫХ РАСТЕНИЙ И ИХ ДИКИХ РОДИЧЕЙ

Пороховинова Е. А. Генетический контроль восстановления фертильности пыльцы у линий льна (Linum usitatissimum L.) с цитоплазматической мужской стерильностью.

\section{ИДЕНТИФИКАЦИЯ ГЕНЕТИЧЕСКОГО РАЗНООБРАЗИЯ КУЛЬТУРНЫХ РАСТЕНИЙ И ИХ ДИКИХ РОДИЧЕЙ ДЛЯ РЕШЕНИЯ ФУНДАМЕНТАЛЬНЫХ И ПРИКЛАДНЫХ ПРОБЛЕМ}

Канцаева У. И., Горина В. М. Морфолого-биологические признаки крупноплодной алычи (Prunus $\times$ rossica Eremin) и их значение для проведения экспертизы сортов на отличимость, однородность и стабильность (ООС).

\section{ИММУНИТЕТ КУЛЬТУРНЫХ РАСТЕНИЙ И ИХ ДИКИХ РОДИЧЕЙ}

Бирюкова В. А., Шмыгля И. В., Абросимова С. Б., Мананков В. В., Митюшкин А. В., Рогозина Е. В., Киру С. Д., Чалая Н. А., Мелешин А. А., Жарова В. А. Применение молекулярных маркеров в селекции на устойчивость к картофельной цистообразующей нематоде.

\section{ИСТОРИЯ АГРОБИОЛОГИЧЕСКИХ ИССЛЕДОВАНИЙ И ВИР. СЛАВНЫЕ ИМЕНА}

Орел Л. И., Трускинов Э. В. Григорий Андреевич Левитский. 


\section{CONTENTS}

\section{STUDYING AND UTILIZATION OF PLANT GENETIC RESOURCES}

Dzyubenko N. I., Bukhteeva A. V., Kochegina A. A. Perennial and annual drought- and saltresistant forage plants in the Vavilov collection.

Dobrenkov E. A., Semenova L. G., Dunaeva S. E., Ukhatova Y. V. Adaptation of in vitro blackberry plants to field environments.

\section{COLLECTIONS OF THE WORLD'S CROP GENETIC RESOURCES FOR THE DEVELOPMENT OF PRIORITY PLANT BREEDING TRENDS}

Kobyliansky V. D., Solodukhina O. V., Lunegova I. V., Novikova S. P., Hlopyuk M. S., Makarov V. I. Rye breeding for low-pentosans and possibility of its use in animal feeding. .... Kuznetsova T. E., Levshtanov S. A., Serkin N. V. Oat breeding in the Kuban region. ......... Kuzmina S. P., Kazydub N. G., Chernenko E. A. Prospects and results of studying the collection of chickpea from VIR at Omsk state Agrarian University. Lapinski B., Rachwalska A. Using Avena macrostachya for improvement of oat winterhardiness in Poland.

32

GENETICS OF CULTIVATED PLANTS AND THEIR WILD RELATIVES

Porokhovinova E. A. Genetic control of fertility restoration in CMS lines of flax (Linum usitatissimum).

IDENTIFICATION OF THE DIVERSITY OF CULTIVATED PLANTS AND THEIR WILD RELATIVES FOR SOLVING FUNDAMENTAL AND APPLIED PROBLEMS

Kantsayeva U. I., Gorina V. M. Morphological and biological traits of large-fruited cherry plum (Prunus $\times$ rossica Eremin) and their importance for expert examination of varieties for their distinctness, homogeneity and stability (DHS).

\section{IMMUNITY OF CULTIVATED PLANTS AND THEIR WILD RELATIVES}

Biryukova V. A., Smiglya I. V., Abrosimova S. B., Manankov V. V., Mityushkin A. V., Rogozina E. V., Kiru S. D., Chalaya N. A., Meleshin A. A., Zharova V. A. Application of molecular markers in breeding for resistance to potato cyst nematode.

\section{HISTORY OF AGROBIOLOGICAL RESEARCH AND VIR. NAMES OF RENOWN}

Orel L. I., Truskinov E. V. Grigory Andreevich Levitsky. 
Научное издание

ТРУДЫ ПО ПРИКЛАДНОЙ БОТАНИКЕ, ГЕНЕТИКЕ И СЕЛЕКЦИИ, ТОМ 178, ВЫПУСК 1

Выпускающий редактор Е. И. Гаевская Научные редакторы $E$. А Соколова, И. Г. Чухина Компьютерная верстка Л. Ю. Шипилина

Подписано в печать 17.03.2017 Формат бумаги 70×100 1/8

Бумага офсетная. Печать офсетная

Печ. л. 15 Тираж 300 экз. Зак.2303/17

Сектор редакционно-издательской деятельности ВИР 190000, Санкт-Петербург, Большая Морская ул., 44

ООО «Р - КОПИ»

Санкт-Петербург, пер. Гривцова, $6^{\mathrm{B}}$ 